DOE/AL/62350-150

REV. 0

\title{
BASELINE RISK ASSESSMENT OF GROUND WATER CONTAMINATION AT THE INACTIVE URANIFEROUS LIGNITE Ashing Site NeAR BOWMAN, NORTH DAKOTA
}

November 1994 


\title{
INTENDED FOR PUBLIC RELEASE
}

This report has been reproduced from the best available copy. Available in paper copy and microfiche.

Number of pages in this report: 166

DOE and DOE contractors can obtain copies of this report from:

Office of Scientific and Technical Information

P.O. Box 62

Oak Ridge, TN 37831

(615) 576-8401

This report is publicly available from:

\author{
National Technical Information Service \\ Department of Commerce \\ 5285 Port Royal Road \\ Springfield, VA 22161 \\ (703) $487-4650$
}

\section{DISCLAIMER}

\footnotetext{
This report was prepared as an account of work sponsored by an agency of the United States Government. Neither the United States Government nor any agency thereof, nor any of their employees, makes any warranty, express or implied, or assumes any legal liability or responsibility for the accuracy, completeness, or usefulness of any information, apparatus, product, or process disclosed, or represents that its use would not infringe privately owned rights. Reference herein to any specific commercial product, process, or service by trade name, trademark, manufacturer, or otherwise does not necessarily constitute or imply its endorsement, recommendation, or favoring by the United States Government or any agency thereof. The views and opinions of authors expressed herein do not necessarily state or reflect those of the United States Government or any agency thereor.
} 


\section{DISCLAIMER}

Portions of this document may be illegible in electronic image products. Images are produced from the best available original document. 


\section{BASELINE RISK ASSESSMENT \\ OF GROUND WATER CONTAMINATION \\ AT THE INACTIVE URANIFEROUS LIGNITE ASHING SITE \\ NEAR BOWMAN, NORTH DAKOTA}

November 1994

Prepared for

U.S. Department of Energy

UMTRA Project Office

Albuquerque, New Mexico

Prepared by

Jacobs Engineering Group Inc.

Albuquerque, New Mexico 


\section{CITIZENS' SUMMARY}

This baseline risk assessment of ground water contamination at the inactive uraniferous lignite ashing site near Bowman, North Dakota, evaluates the potential impacts to public health or the environment from contaminated ground water at this site. This contamination is a result of the uraniferous lignite ashing process, when coal containing uranium was burned to produce uranium. Potential risk is quantified only for constituents introduced by the processing activities and not for the constituents naturally occurring in background ground water in the site vicinity. Background ground water, separate from any site-related contamination, imposes a percentage of the overall risk from ground water ingestion in the Bowman site vicinity. This portion of the potential risk was not evaluated independently. Constituents determined to be present at higher levels in on-site wells than in off-site background wells were attributed to the processing site. Risk from ingesting the worst on-site ground water was quantified. Constituents found both on-site and off the site at equivalent levels were not attributed to site activities.

The U.S. Department of Energy (DOE) Uranium Mill Tailings Remedial Action (UMTRA) Project is developing plans to address soil and ground water contamination at the site. The UMTRA Surface Project involves the determination of the extent of soil contamination and design of an engineered disposal cell for long-term storage of contaminated materials. The UMTRA Ground Water Project evaluates ground water contamination. This risk assessment was conducted under the UMTRA Ground Water Project to help determine an appropriate ground water compliance strategy for the site.

Based on results from future site monitoring activities as defined in the site observational work plan and results from this risk assessment, the DOE will propose an approach for managing contaminated ground water at the Bowman site. The framework by which these decisions will be made is presented in the Programmatic Environmental Impact Statement (PEIS) for the Uranium Mill Tailings Remedial Action Ground Water Project (DOE, 1994). The site-specific ground water compliance strategy will be evaluated through site-specific National Environmental Policy Act documentation tiering off the PEIS, and supported by other site-specific technical documents.

\section{Potential public health impacts}

This risk assessment follows the basic framework prescribed by the U.S. Environmental Protection Agency (EPA) coupled with probabalistic determinations of contaminant concentrations and intake. There are no current exposure pathways to contaminated ground water at the site. Therefore, no current human health risks exist. No one drinks the site-affected ground water and there is no surface expression of contaminated ground water.

In the immediate site vicinity, no municipal water supply is available and local ground water is used for domestic purposes. The town of Bowman, 7 miles west of the processing site, is supplied by a municipal water supply. Although site-related contamination has not been identified in either of the two domestic wells adjacent to the site and bottled water is used for drinking at this residence, it may be possible for 
contaminated ground water to impact ground water in these wells and for this water to be used for drinking. Therefore, this risk assessment evaluates a potential future ground water use scenario.

This risk assessment evaluates the potential future risk of exposure to contaminants in ground water at the site through drinking. This looks at a possible future conservative worst case scenario. Ground water quality data from the most contaminated monitor wells at and around the site over the last 8 years were evaluated. Sodium, sulfate, molybdenum, and uranium were identified as the main site-related contaminants of potential concern for human health. Probability distributions are used to estimate the range of possible exposures to contaminants if shallow ground water at the Bowman site was ingested on a continuous basis. The probability distributions describe probability of occurrence, taking into account the range of tap water consumption, body weights within a given group of people, and the range of possible contaminant concentrations.

The estimated amount of contaminants that people might ingest from tap water are compared to the noncarcinogenic toxic effects these contaminant levels might cause. Based on this analysis, levels of molybdenum, sodium, and sulfate could cause mild toxic effects from long-term ingestion of contaminated ground water at the Bowman site. Elevated molybdenum levels could cause mild physiologic changes that manifest as copper deficiency symptoms. Chronic sulfate ingestion at the levels present at the Bowman site would likely cause mild diarrhea in adults. However, potentially severe diarrhea could occur in infants. The potential interaction of sulfate with nonsite-related nitrate in ground water in the site vicinity may also be a concern for infants because background nitrate levels are above levels known to cause acute toxicity to infants in the form of methemoglobinemia. Sodium intakes are around the range that could cause hypertension in adults or children. Susceptibility to hypertension would influence the manifestation of this toxic response. Health impacts from ingesting natural uranium in ground water are not well identified in the literature creating great uncertainty in the interpretation of risk from uranium.

The cancer risk from drinking water contaminated with uranium at levels measured at the site may exceed the EPA-acceptable risk of 1 additional cancer in 10,000 persons. However, most of the predicted exposures to uranium fall below this level.

\section{Potential environmental impacts}

Potential impacts to ecological receptors from site-related contaminated ground water are not expected at the Bowman site. The ground water is not hydraulically connected to any surface water bodies and direct exposure of biota to ground water has not been identified. Without an exposure pathway, risk to ecological receptors does not exist.

A potential future exposure pathway could include a hypothetical man-made, ground water-fed pond that is open to livestock, wildlife, and/or aquatic organisms. In this case the ground water would be acceptable for livestock watering although there is a degree of uncertainty for some contaminants. Aquatic organisms are not expected in the site vicinity. 
Irrigation with contaminated ground water could also be a potential future exposure pathway to biota. However, dry land farming is the main farming activity in southwestern North Dakota. Irrigation is not a likely use for shallow ground water in the site vicinity because of the limited yield ability of the upper aquifer. The potential for shallow ground water to be used for irrigation would be limited to small-scale operations like gardens. If contaminated ground water were used for irrigation, plants could be at risk due to the high total dissolved solids (related to the sulfate and sodium levels) of the ground water. 


\section{TABLE OF CONTENTS}

Section

Page

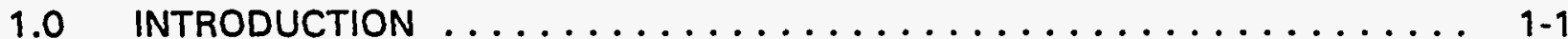

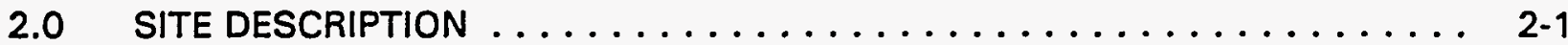

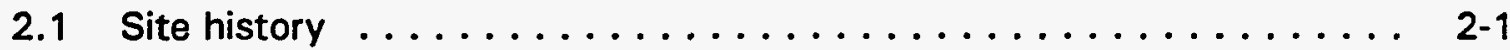

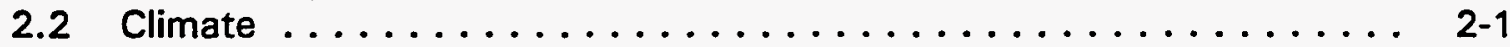

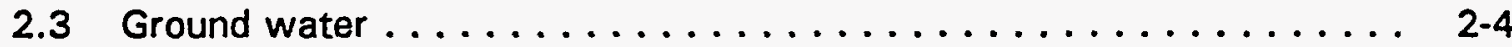

2.3.1 Hydrogeology ....................... 2-4

2.3.2 Hydraulic characteristics ................... 2-4

2.3.3 Ground water monitoring ................... 2-.

2.4 Surface water ........................... $2-9$

2.4.1 Surface water hydrology ................. 2-9

2.4.2 Surface water monitoring ............... 2-13

2.5 Land use ............................ 2-13

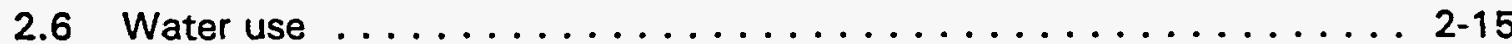

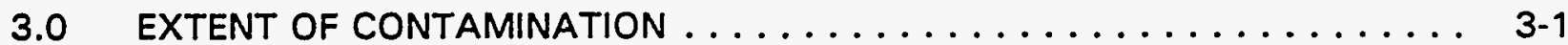

3.1 Background water quality summary ... . . . . . . . . . . 3-1

3.1.1 Regional background ground water quality .......... 3-3

3.1.2 Background ground water quality in the vicinity of the

Bowman site ....................... 3-4

3.2 Magnitude and extent of site-related contamination . . . . . . . . 3-5

3.2.1 Site-related contamination in shallow ground water ...... 3-6

3.2.2 Site-related contamination in the lower zone ......... 3-13

3.3 Contaminants of potential concern ................ 3-18

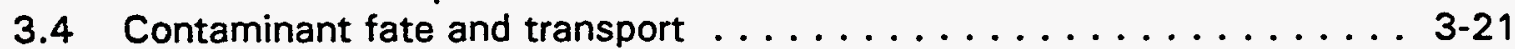

3.5 Surface water quality ...................... 3-25

4.0 EXPOSURE ASSESSMENT $\ldots \ldots \ldots \ldots \ldots \ldots \ldots \ldots \ldots \ldots \ldots \ldots \ldots \ldots$

4.1 Potentially exposed population ................... 4-1

4.2 Exposure pathways ....................... 4 . 2

4.2.1 Drinking water ingestion ................. 4-2

4.2.2 Dermal absorption .................... 4-2

4.2.3 Ingestion of ground water-irrigated produce . . . . . . . . 4-6

$4.2 .4 \quad \begin{aligned} & \text { Ingestion of milk or meat from ground water-fed } \\ & \text { livestock } \ldots \ldots \ldots \ldots \ldots \ldots \ldots \ldots \ldots \ldots \ldots \ldots\end{aligned}$

4.2 .5 Summary ....................... 4-6

4.3 Exposure concentrations ..................... 4-10

4.4 Estimation of intake through drinking water ............. 4-10

4.5 Exposure assessment uncertainties ................. 4-21

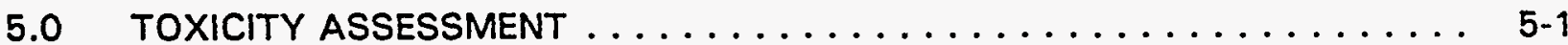

5.1 Contaminant toxicity summaries $\ldots \ldots \ldots \ldots \ldots \ldots \ldots \ldots \ldots \ldots$

$5.1 .1 \quad$ Arsenic ....................... $5-1$

5.1 .2 Selenium ...................... 5-5 


\section{TABLE OF CONTENTS (Concluded)}

Section

Page

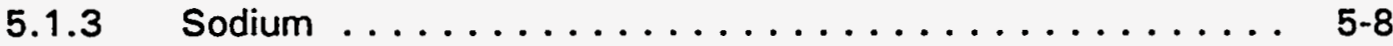

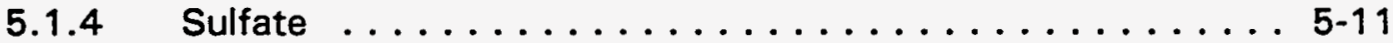

5.1 .5 Molybdenum .................... 5-13

5.1 .6 Uranium ...................... 5-16

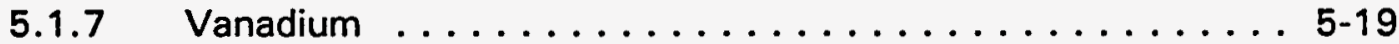

5.2 Contaminant interactions . . . . . . . . . . . . . . . 5-23

5.3 Contaminant toxicity values . . . . . . . . . . . . . . . 5-26

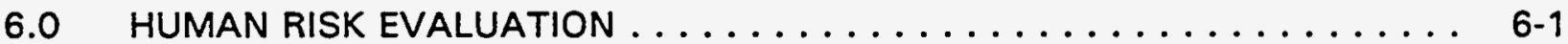

6.1 Potential noncarcinogenic health effects . . . . . . . . . . . 6 6-1

6.2 Potential carcinogenic health effects . . . . . . . . . . . . . . 6 6-9

6.3 Limitations of risk evaluation ................... 6-13

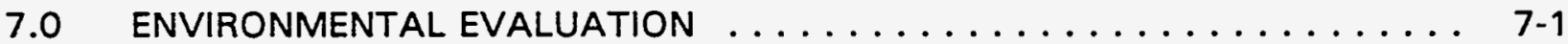

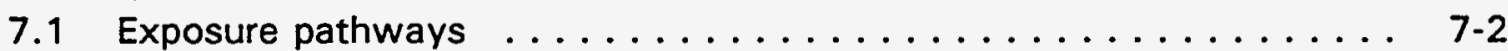

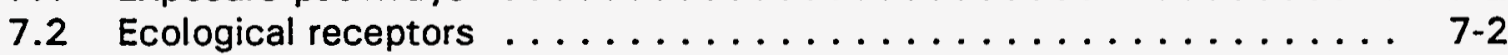

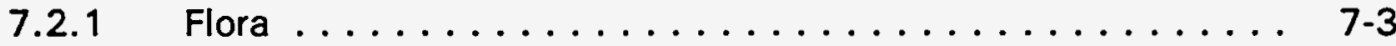

7.2 .2 Terrestrial fauna .................... 7.3

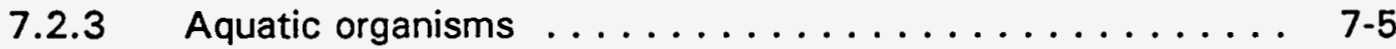

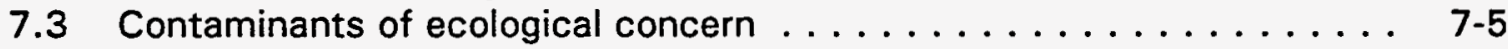

7.4 Potential risks to biota . . . . . . . . . . . . . . . $7-6$

7.5 Sediments ............................ 7-10

7.6 Uncertainties of the ecological risk assessment $\ldots \ldots \ldots \ldots \ldots \ldots$. . . . . . . . .

7.7 Summary .......................... 7-10

8.0 INTERPRETATION AND RECOMMENDATIONS $\ldots \ldots \ldots \ldots \ldots \ldots \ldots \ldots$

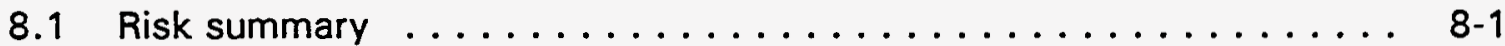

8.2 Limitations of this risk assessment . . . . . . . . . . . . . 8-2

8.3 Ground water criteria $\ldots \ldots \ldots \ldots \ldots \ldots \ldots \ldots \ldots \ldots . \ldots \ldots \ldots$

8.4 Risk mitigation measures/institutional controls . . . . . . . . . . . 8 8 -4

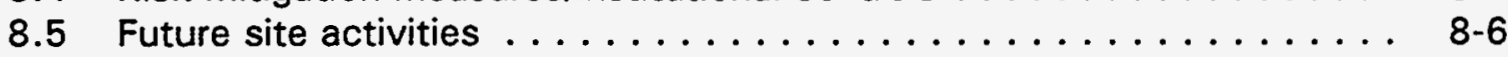

8.6 Recommendations ...................... 8-6

9.0 LIST OF CONTRIBUTORS ......................... $9-1$

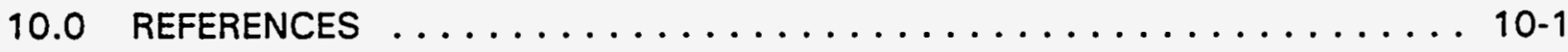




\section{LIST OF FIGURES}

Figure

2.1 Location of the Bowman, North Dakota, site ... . . . . . . . . . . 2-2

2.2 Site conditions, Bowman, North Dakota, site . . . . . . . . . . . . . . 2-3

2.3 Hydrogeologic cross section B-B' of the Bowman, North Dakota,

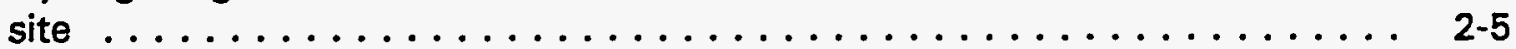

2.4 Water table of the upper zone at the Bowman, North Dakota, site . . . . . 2-7

2.5 Potentiometric surface of the lignite zone at the Bowman, North Dakota, site ................................ 2-8

2.6 Locations of DOE monitor wells, Bowman, North Dakota, site . . . . . . . . . 2-10

2.7 Locations of existing domestic wells, Bowman, North Dakota, site . . . . . . 2-11

2.8 Regional drainage features at the Bowman, North Dakota, site . . . . . . . . 2-12

2.9 Surface water sampling dates and locations, Bowman, North Dakota,

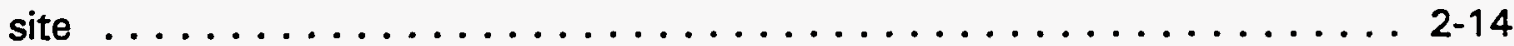

3.1 Total dissolved solids with depth, Bowman, North Dakota, site . . . . . . 3-12

4.1 Exposure pathways conceptual model, Bowman, North

Dakota, site ............................. 4-3

4.2 Probability distribution of arsenic concentrations, Bowman, North

Dakota, site . . . . . . . . . . . . . . . . . . . . . . 4-11

4.3 Probability distribution of selenium concentrations, Bowman, North

Dakota, site . . . . . . . . . . . . . . . . . . . . . 4-12

4.4 Probability distribution of sodium concentrations, Bowman,

North Dakota, site . . . . . . . . . . . . . . . . . . . . . . 4-13

4.5 Probability distribution of sulfate concentrations, Bowman,

North Dakota, site . . . . . . . . . . . . . . . . . . . . . . . . 4-14

4.6 Probability distribution of molybdenum concentrations, Bowman,

North Dakota, site . . . . . . . . . . . . . . . . . . . . . . 4-15

4.7 Probability distribution of uranium concentrations, Bowman,

North Dakota, site . . . . . . . . . . . . . . . . . . . . . . . 4-16

4.8 Probability distribution of vanadium concentrations, Bowman,

North Dakota, site . . . . . . . . . . . . . . . . . . . . 4-17

4.9 Probability distributions for tap water ingestion rates $\ldots \ldots \ldots \ldots \ldots$. . . . . 49

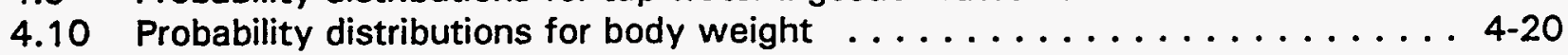

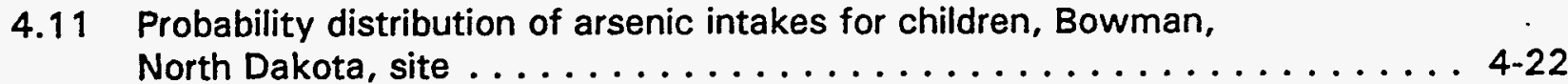

4.12 Probability distribution of selenium intakes for children, Bowman, $4-23$

North Dakota, site . . . . . . . . . . . . . . . . . . . . . 4-23

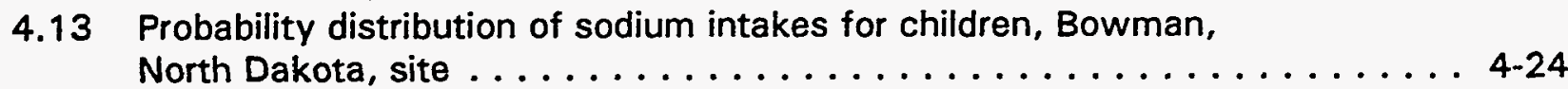

4.14 Probability distribution of sulfate intakes for infants, Bowman,

North Dakota, site . . . . . . . . . . . . . . . . . . . . 4-25

4.15 Probability distribution of molybdenum intakes for children, Bowman,

North Dakota, site . . . . . . . . . . . . . . . . . . . 4-26 


\section{LIST OF FIGURES (Concluded)}

Figure

4.16 Probability distribution of uranium intakes for children, Bowman, North Dakota, site . . . . . . . . . . . . . . . . . . . . . .

4.17 Probability distribution of vanadium intakes for children, Bowman, North Dakota, site . . . . . . . . . . . . . . . . . . . . . . 4-28

4.18 Probability distribution of arsenic intakes over a lifetime for adults, Bowman, North Dakota, site . . . . . . . . . . . . . . . . . 4 4-29

4.19 Probability distribution of uranium intakes over a lifetime for adults, Bowman, North Dakota, site . . . . . . . . . . . . . . . . . 4-30

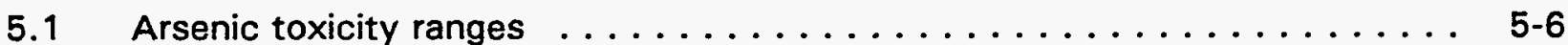

5.2 Selenium toxicity ranges $\ldots \ldots \ldots \ldots \ldots \ldots \ldots \ldots \ldots \ldots \ldots \ldots$

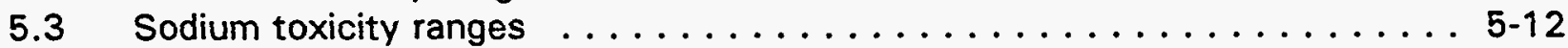

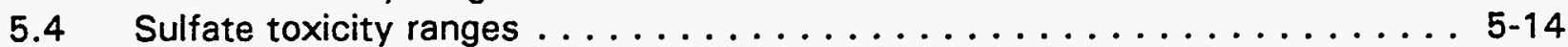

5.5 Molybdenum toxicity ranges . . . . . . . . . . . . . . . . 5-17

5.6 Half-lives and emissions from decay chain of uranium-238 $\ldots \ldots \ldots \ldots$. . . . . 58

5.7 Uranium toxicity ranges . . . . . . . . . . . . . . . . . . 5-20

5.8 Vanadium toxicity ranges . . . . . . . . . . . . . . . . . . 5-24

6.1 Health effects of potential molybdenum exposure ranges for children, Bowman, North Dakota, site . . . . . . . . . . . . . . . . . 6-2

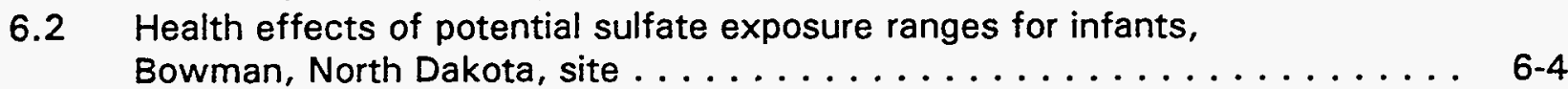

6.3 Health effects of potential sodium exposure ranges for children,

6.4 Health effects of potential selenium exposure ranges for children,

6.5 Health effects of potential arsenic exposure ranges for children,

6.6 Health effects of potential vanadium exposure ranges for children,

6.7 Health effects of potential uranium exposure ranges for children, Bowman, North Dakota, site . . . . . . . . . . . . . . . . . . . . 6-10

6.8 Increased lifetime cancer risk from predicted uranium intakes for adults ingesting contaminated ground water, Bowman, North Dakota, site ............................... 6-12

6.9 Increased lifetime cancer risk from predicted arsenic intakes for adults ingesting contaminated ground water, Bowman, North Dakota, site ............................. 6-14

7.1 Plant community types at the Bowman, North Dakota, site $\ldots \ldots \ldots$. . . 7-4 


\section{LIST OF TABLES}

Table

Page

3.1 Monitor well information for the Bowman, North Dakota, site . . . . . . . . 3-2

3.2 Summary of filtered water quality in the shallow ground water system near Bowman, North Dakota, 1986-1993 . . . . . . . . . . . . . . .

3.3 Summary of filtered water quality in the lower zone near Bowman, North Dakota (1986-1990) . . . . . . . . . . . . . . . . . . . . . . . . . 3-14

3.4 Summary of contaminants of potential concern for human health in the shallow ground water system, Bowman, North Dakota, site . . . . . . 3-19

3.5 Geochemical analysis of the contaminants of potential concern in shallow ground water at the Bowman, North Dakota, site . . . . . . . . . . .

4.1 Exposure dose calculations for ground water ingestion and dermal contact, Bowman, North Dakota, site . . . . . . . . . . . . . . . . . 4-4

4.2 Exposure dose calculations for ground water-irrigated garden produce ingestion, Bowman, North Dakota, site . . . . . . . . . . . . . . 4-7

4.3 Exposure dose calculations for ingestion of milk from ground water-fed livestock, Bowman, North Dakota, site . . . . . . . . . . . . . . 4 4-8

4.4 Exposure dose calculations for ingestion of meat from ground water-fed livestock, Bowman, North Dakota, site . . . . . . . . . . . . .

5.1 Toxicity values: potential noncarcinogenic effects $\ldots \ldots \ldots \ldots \ldots \ldots$

5.2 Toxicity values: potential carcinogenic effects . . . . . . . . . . . 5-27

6.1 Excess lifetime cancer risk calculations for ground water ingestion by a hypothetical future adult resident, Bowman, North Dakota, site ......

7.1 Comparison of shallow ground water quality data with available surface water quality criteria for the protection of aquatic organisms, wildlife, and livestock, near the Bowman, North Dakota, site . . . . . . . . . .

7.2 Comparison of estimated plant concentrations to phytotoxic concentrations near the Bowman, North Dakota, site ............ 7-9

7.3 Comparison of metals in sediments near Bowman, North Dakota, site with sediment quality values $\ldots \ldots \ldots \ldots \ldots \ldots \ldots \ldots \ldots$ 7-11

8.1 Concentration limits $\ldots \ldots \ldots \ldots \ldots \ldots \ldots \ldots \ldots \ldots \ldots \ldots \ldots \ldots \ldots$ 


\section{LIST OF ACRONYMS}

\section{Acronym Definition}

$\begin{array}{ll}\text { ACL } & \text { alternate concentration limit } \\ \text { BCF } & \text { bioconcentration factors } \\ \text { DHHS } & \text { Department of Health and Human Services } \\ \text { DOE } & \text { U.S. Department of Energy } \\ \text { EPA } & \text { U.S. Environmental Protection Agency } \\ \text { FWOC } & \text { Federal Water Quality Criterion } \\ \text { FWS } & \text { U.S. Fish and Wildlife Service } \\ \text { HEAST } & \text { Health Effects Assessment Summary Tables } \\ \text { IRIS } & \text { Integrated Risk Information System } \\ \text { MCL } & \text { maximum concentration limits } \\ \text { NEPA } & \text { National Environmental Policy Act } \\ \text { PEIS } & \text { Programmatic Environmental Impact Statement } \\ \text { Ppm } & \text { parts per million } \\ \text { RDA } & \text { recommended dietary allowance } \\ \text { RfD } & \text { reference doses } \\ \text { SOWP } & \text { site observational work plan } \\ \text { T\&E } & \text { threatened and endangered } \\ \text { TDS } & \text { total dissolved solids } \\ \text { UMTRA } & \text { Uranium Mill Tailings Remedial Action } \\ \text { UMTRCA } & \text { Uranium Mill Tailings Radiation Control Act }\end{array}$




\subsection{INTRODUCTION}

The purpose of this baseline risk assessment is to determine whether ground water contamination at the uraniferous lignite ashing site in Bowman County, North Dakota, could adversely affect public health or the environment. The Bowman site is 1 of 24 abandoned uranium processing sites that are undergoing remediation in accordance with the requirements of the Uranium Mill Tailings Radiation Control Act (UMTRCA) of 1978 (Public Law 95-604) (42 USC \$7901 et seq.) under the oversight of the U.S. Department of Energy (DOE) Uranium Mill Tailings Remedial Action (UMTRA) Project.

Under the UMTRA Surface Project, the DOE stabilizes residual radioactive materials in a disposal cell to minimize radon and other radiation emissions and prevent further contamination of ground water. The 1988 amendments to the UMTRCA authorize the DOE to conduct ground water restoration activities. The UMTRA Ground Water Project evaluates site-related ground water contamination to determine what is needed to reach compliance with the U.S. Environmental Protection Agency (EPA) ground water quality standards.

The programmatic environmental impact statement (PEIS) for ground water contamination at the UMTRA sites (DOE, 1994), describes the framework for addressing the cleanup of contaminated ground water at UMTRA Project sites. This baseline risk assessment is the first site-specific document for the Bowman site prepared under the UMTRA Ground Water Project. The risk assessment evaluates potential health and environmental risks associated with contaminated ground water, providing information that will help in selecting the necessary ground water compliance strategy. Any data gaps identified in the baseline risk assessment are addressed in the site observational work plan (SOWP) which presents the remedial action selection process outlined in the PEIS. The ground water compliance strategy will be based on the PEIS framework, the SOWP process, and results of this risk assessment; this compliance strategy will be planned in a site-specific environmental assessment.

This risk assessment is a baseline assessment in that it describes pre-remediation ground water conditions at the site, with ground water contamination not fully characterized to eliminate all uncertainties. Nonetheless, this document evaluates the potential for imminent public health or environmental risk that may need near-term attention. All critical data gaps are identified and limitations to the risk assessment presented.

This evaluation is based on all available ground water data, focusing on the most contaminated wells at the processing site; only major exposure pathways have been thoroughly examined. If future data collection, decisions, or actions at this site change conditions, other pathways will be evaluated.

This risk assessment follows the basic EPA framework (EPA, 1989a) for evaluating hazardous waste sites to assess potential health and environmental impacts resulting from ground water contamination. Probabilistic determinations of ground water concentrations and exposure parameters were applied within this framework. This methodology is described in the UMTRA Project risk assessment methodology document currently in 
preparation. A nonquantitative assessment of noncancer risk is presented as a range of potential adverse effects associated with a range of exposure possibilities.

The risk assessment process consists of the following steps:

- Data Evaluation

- Combining data from various site investigations.

- Comparing sample results with background and tailings source data.

- Selecting chemical data for use in the risk assessment.

- Exposure assessment

- Characterizing exposure setting.

- Identifying exposure pathways.

- Quantifying exposure as a distribution or range.

- Toxicity assessment

- Identifying toxicity values.

- Evaluating noncarcinogenic effects.

- Evaluating carcinogenic effects from radionuclides and chemical carcinogens.

- Public health risk characterization

- Comparing toxicity ranges to predicted exposure ranges.

- Combining risks across exposure pathways and multiple contaminants.

- Characterizing uncertainties.

- Environmental risk

- Characterizing potential biota exposure pathways.

- Identifying potential ecological receptors.

- Evaluating environmental risk qualitatively.

This framework is incorporated into the methodology prepared for the evaluation of human health risks at UMTRA Project sites, which evaluates risks from potential use of contaminated ground water and surface water near the UMTRA sites. 


\subsection{SITE DESCRIPTION}

The 12.1 acre (ac) (4.9 hectare [ha]) inactive uraniferous lignite ashing site in Bowman County, North Dakota, is 7 miles (mi) $(11$ kilometers [km]) west of the town of Bowman along U.S. Highway 12, approximately $25 \mathrm{mi}$ north of the South Dakota border and $35 \mathrm{mi}$ east of the Montana border (Figure 2.1). The site is in the northeast quarter of Section 34, Township 132 north, Range 103 west, Fifth Principal Meridian. The designated site boundary runs approximately 200 feet (ft) $(61$ meters [m]) north of U.S. Highway 12 . The site is bounded on the north by the Burlington Northern Railroad (Figure 2.2). An access road to a residence just north of the railroad bisects the site.

\subsection{SITE HISTORY}

V. Soderstrom leased land to Kermac Nuclear Fuels Corporation, a subsidiary of Kerr-McGee Oil Industries, from 1964 to 1967 for a uraniferous lignite ashing plant. Uraniferous lignite was hauled from mines in the region and stockpiled on the site. The raw lignite was loaded into hoppers, crushed, and fed into three rotating $7-\mathrm{ft}(2-\mathrm{m})$-diameter by $120-\mathrm{ft}(37-\mathrm{m})$-long kilns. Burned material discharged from a shaker conveyor onto a vibrating screen for size separation. Oversized material was further crushed. An elevator system loaded the final product into railroad cars where it was shipped to Kerr-McGee's Ambrosia Lake uranium mill near Grants, New Mexico. Further chemical processing to extract uranium and molybdenum byproduct occurred at Ambrosia Lake. No chemical, metallurgical, or nuclear processes occurred at the Bowman site. The Bowman operation processed an average of 80 to 90 tons of raw lignite per day. Approximately 80,000 dry tons of burned material were shipped over the lifespan of the operation (FBDU, 1981). When the plant closed, the site was leveled, leaving no visible ash pile. The western portion of the site is fenced with barbed wire. A thick cover of nonnative grasses has vegetated the entire site.

Contaminated soil dispersed by wind and water erosion cover $64.6 \mathrm{ac}$ ( $27 \mathrm{ha}$ ) (DOE, 1990) (Figure 2.2). The soil contamination at the site may have resulted from incomplete ash recovery during lignite combustion, material separation, or loading ash onto rail cars. It is questionable whether this amount of source material on the ground surface could have contaminated ground water. However, knowing that precipitation recharges ground water in the site area and heavy rain and snowfall are common in southwestern North Dakota, contaminants could have leached from lignite stockpiles or contaminated soils, resulting in ground water contamination.

\subsection{CLIMATE}

The weather station nearest the Bowman site is in Dickinson, North Dakota, approximately $80 \mathrm{mi}(130 \mathrm{~km})$ northeast of the town of Bowman. Annual temperatures recorded at Dickinson include an average maximum of 54 degrees Fahrenheit $\left({ }^{\circ} \mathrm{F}\right),\left(12\right.$ degrees Celsius $\left.\left[{ }^{\circ} \mathrm{C}\right]\right)$ and an average minimum of $30^{\circ} \mathrm{F}$ 

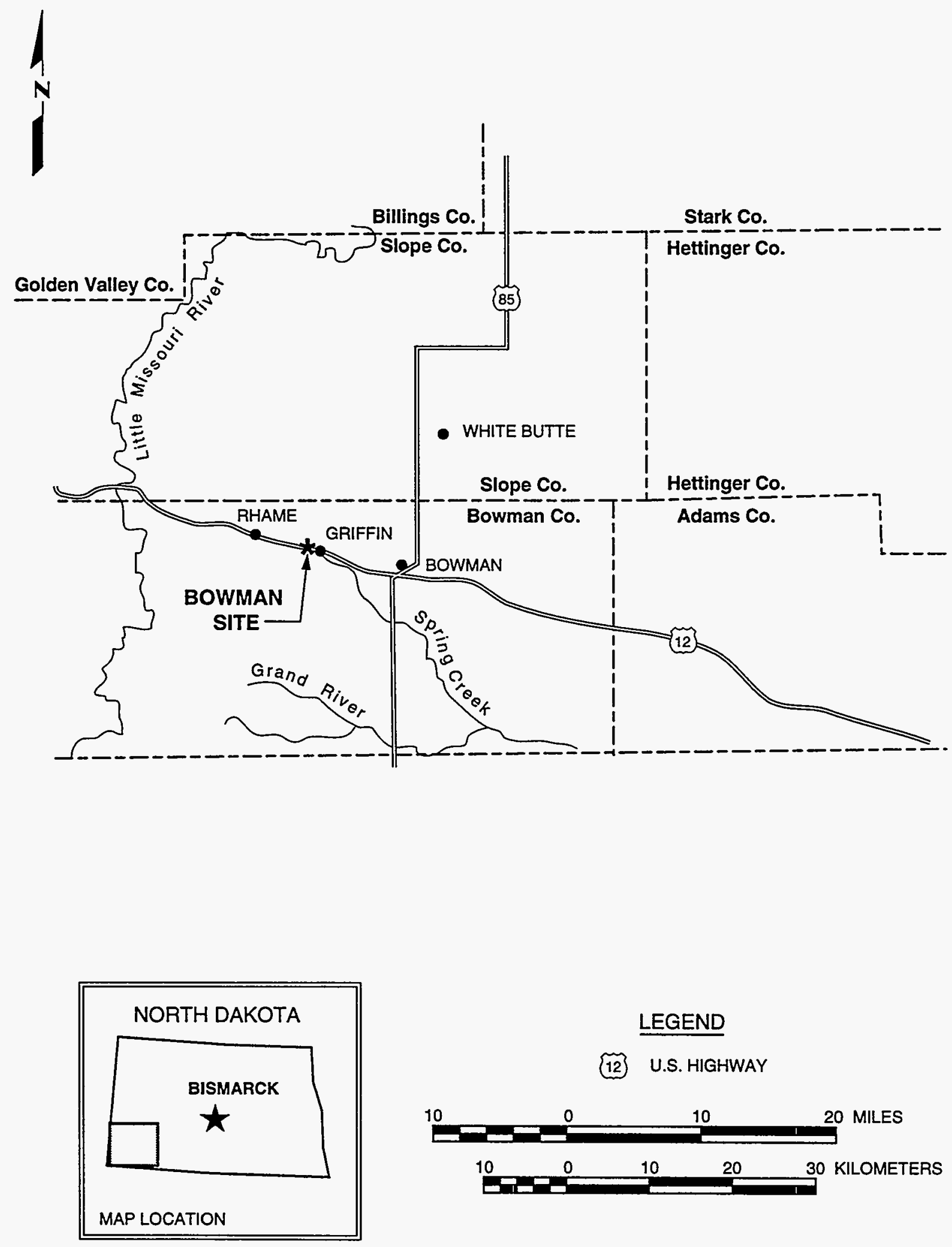

FIGURE 2.1

LOCATION OF THE

BOWMAN, NORTH DAKOTA, SITE 


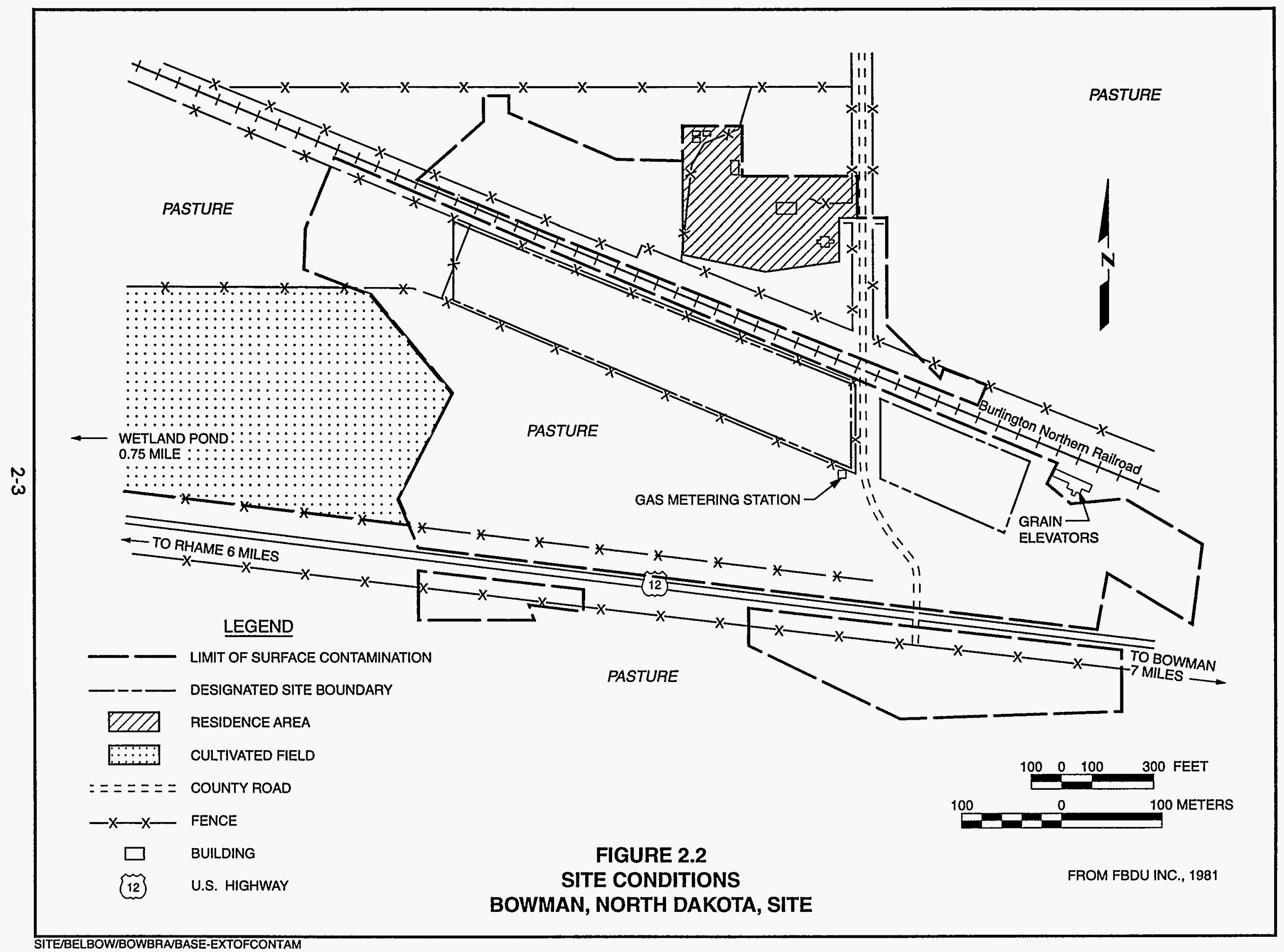


$\left(-1^{\circ} \mathrm{C}\right)$, with extremes of 105 and $-35^{\circ} \mathrm{F}\left(41\right.$ and $\left.-37^{\circ} \mathrm{C}\right)$ for the 30 years on record. Prevailing winds for the area, as measured from Dickinson, are from the west. Windspeeds are moderate, with 75 percent of the observations showing speeds below $16 \mathrm{mi}(26 \mathrm{~km})$ per hour, and 95 percent below $22 \mathrm{mi}(35 \mathrm{~km})$ per hour, with an average annual wind speed of $13 \mathrm{mi}(20 \mathrm{~km})$ per hour. At Dickinson, the average annual rainfall is 16 inches (40 centimeters [cm]), 80 percent of which falls between April and September, with an average annual snowfall of 30 inches $(80 \mathrm{~cm})$. The potential evapotranspiration measured for Bowman County is approximately twice the average rainfall during the growing season. However, dry land farming is common. Surface water and ground water are limited in this area, making crops susceptible to drought. The mean annual precipitation for the town of Bowman is approximately 15.3 inches $(38.9 \mathrm{~cm})$.

\subsection{GROUND WATER}

\subsubsection{Hydrogeology}

The Bowman UMTRA site is in the Missouri Plateau of the northern Great Plains physiographic province. The site is underlain by sediments of the Bullion Creek Formation, which is part of the Tertiary Fort Union Group. The Bullion Creek Formation consists of approximately 40 to $60 \mathrm{ft}(12$ to $18 \mathrm{~m})$ of alternating beds of semiconsolidated claystone, siltstone, sandstone, and lignite, with variable amounts of carbonaceous material, which dip northeast at approximately $20 \mathrm{ft} / \mathrm{mi}(4 \mathrm{~m} / \mathrm{km})$. Lithologic logs from DOE monitor wells at the site indicate a 30 to $40 \mathrm{ft}(9$ to $12 \mathrm{~m}$ ) interbedded sequence of silty sandstone, silty claystone, and thin discontinuous lignite stringers underlies a thin soil cover (Figure 2.3). This hydrogeologic unit is referred to as the upper zone. Underlain by a relatively extensive lignite unit that varies from 4 to $7 \mathrm{ft}(1.2$ to $2.1 \mathrm{~m})$ in thickness, it is referred to as the lignite zone. Because of the varying thickness and consistency of the lignite layer, some mixing of ground water with the upper zone is expected. This especially would affect water quality results where well screen intervals cross both zones. The lignite zone is underlain by an interbedded sequence similar to the sandy, silty, claystone layer above the lignite. The layer below the lignite is referred to as the lower zone of fine-grained sediments.

\subsubsection{Hydraulic characteristics}

Ground water occurs in fine-grained sediments and fractured lignites under unconfined to confined conditions at the Bowman site. The water table for the upper zone ranges from 6 to $20 \mathrm{ft}(1.8$ to $6 \mathrm{~m})$ below the ground surface. The potentiometric surface of the lower zone is approximately $30 \mathrm{ft}(9 \mathrm{~m})$ below the ground surface (Figure 2.3). Recharge to ground water is by precipitation and infiltration from intermittent streams and standing surface water in the region. Recharge to the lignite and lower zones is influenced by downward leakage through the upper zone, as well as by subsurface underflow. Ground water recharge in the area is probably slight because soils are not highly permeable 


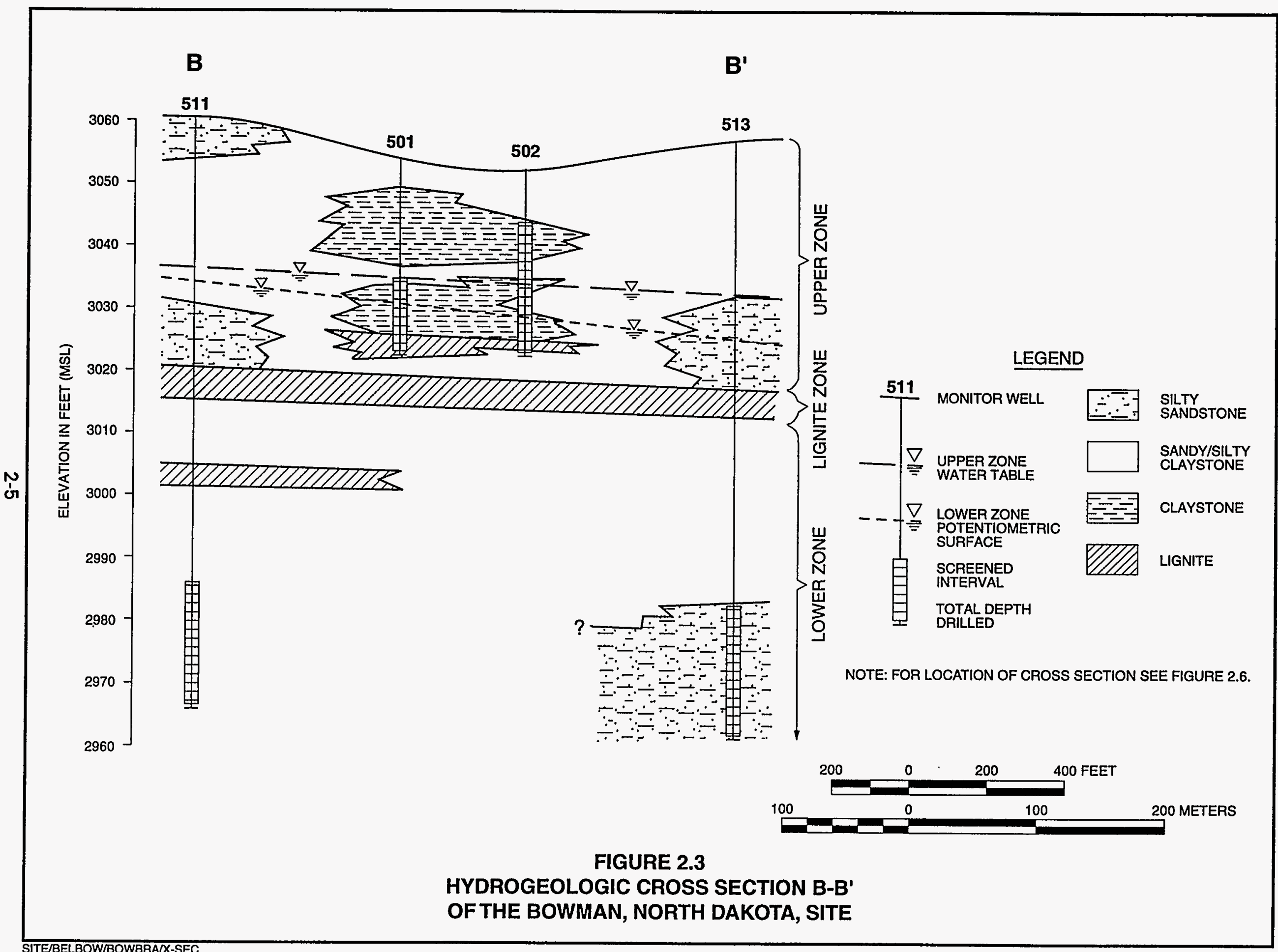


and evapotranspiration consumes most of the soil water during the growing season. Shallow ground water experiences considerable evaporation, also limiting the water available for recharge (DOE, 1990). Seasonal fluctuations in the water table are generally less than $3 \mathrm{ft}(0.9 \mathrm{~m}$ ) (from lowest to highest ground water elevation), in response to spring snowmelt and periods of maximum precipitation during the summer and fall. Surface water infiltration and the lateral and vertical variations in lithology in the area could also be responsible for variability in the water table depth. There is no evidence of natural discharge of ground water from the upper zone or the lignite zone to the land surface or surface water in the vicinity of the Bowman site.

The direction of the local ground water flow at the site varies from the direction of regional flow. Regional ground water flows generally east and northeast. The apparent configuration of the water table in the upper zone beneath the site is a northwest-southeast trending ridge (measured in monitor wells 517 to 530), with local ground water flow both to the northeast and southwest. There is a shallow flow gradient of approximately 0.004 (Figure 2.4). These data suggest the saturated interval in the upper zone is not a laterally continuous, integrated aquifer unit but consists of ground water in perched zones and in heterogeneous units with lateral and vertical facies variations (with a predominance of clay- and silt-sized material). There is hydraulic interconnection within this saturated interval, but varying water levels result from differential equilibration of water percolating through the interval.

The potentiometric surface of the lignite zone indicates that ground water flows generally southeast, with a hydraulic gradient averaging 0.002 or less

(Figure 2.5). The higher transmissivity of the fractured lignite in the upper zone and the low topographic relief of the area facilitate equilibration of ground water levels between the two zones, and the subsequent low hydraulic gradient of the lignite zone. The potentiometric surface of the lower zone indicates ground water flows generally east and southeast, with a hydraulic gradient of 0.005 .

To determine the vertical hydraulic gradient, ground water elevations were compared in adjacent monitor wells screened in each of the three hydrogeologic zones. Ground water elevations were generally higher in the upper zone than in the lignite and lower zones, indicating a potential downward vertical hydraulic gradient.

Aquifer pumping tests conducted in selected DOE monitor wells measured hydraulic parameters in all three hydrogeologic units in the vicinity of the Bowman site (DOE, 1990). The average hydraulic conductivity of the upper zone was estimated to be $0.23 \mathrm{ft}$ per day $\left(8.1 \times 10^{-5}\right.$ centimeters per second $[\mathrm{cm} / \mathrm{s}]$ ). The average hydraulic conductivity of the lignite zone was estimated to be $10.21 \mathrm{ft}$ per day $\left(3.6 \times 10^{-3} \mathrm{~cm} / \mathrm{s}\right)$. The average hydraulic conductivity of the lower zone was estimated to be $0.15 \mathrm{ft}$ per day $\left(5.3 \times 10^{-5} \mathrm{~cm} / \mathrm{s}\right)$.

An average linear ground water velocity calculated for each of the hydrogeologic units was based on measured hydraulic conductivities and hydraulic gradients 


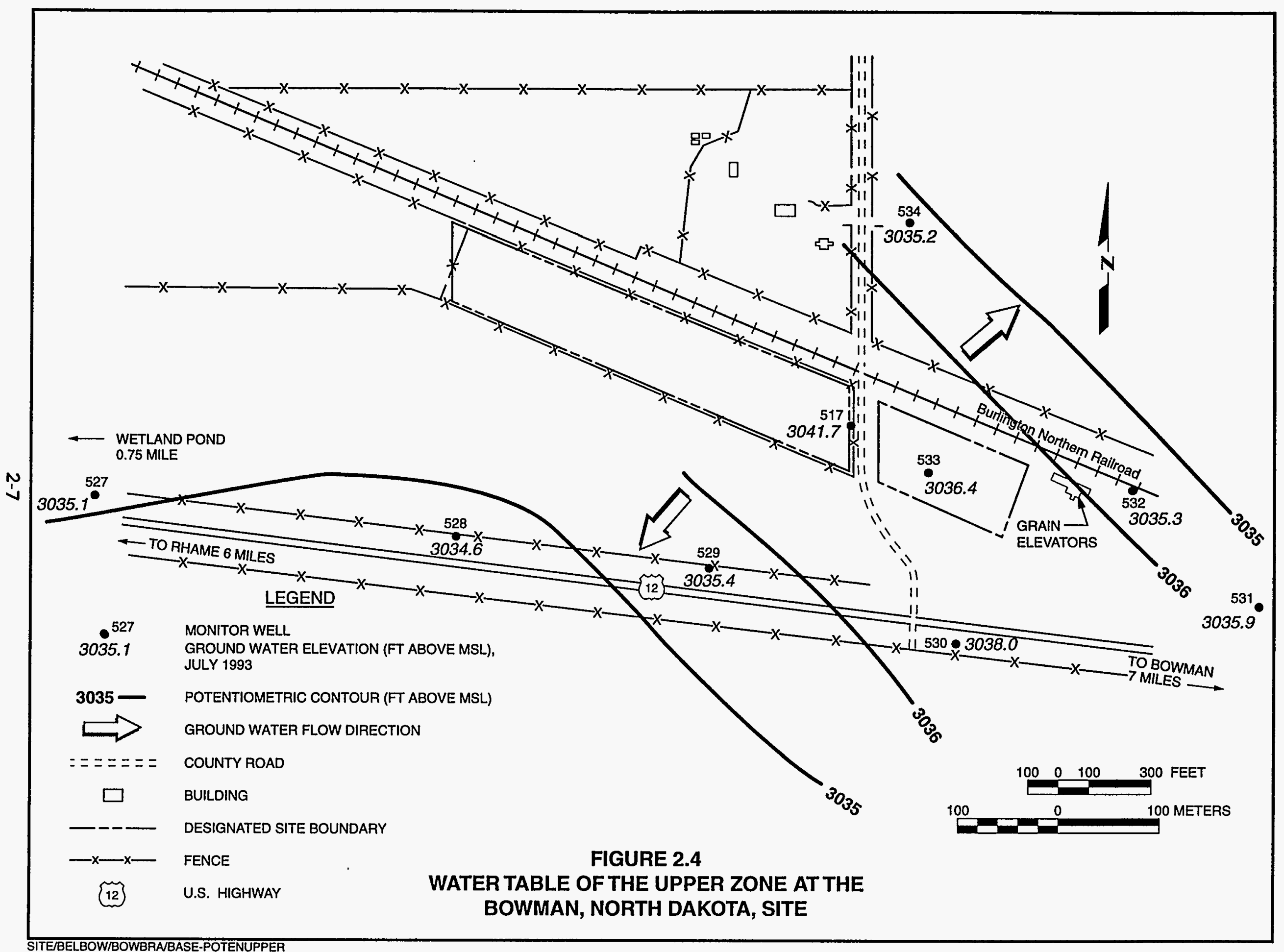




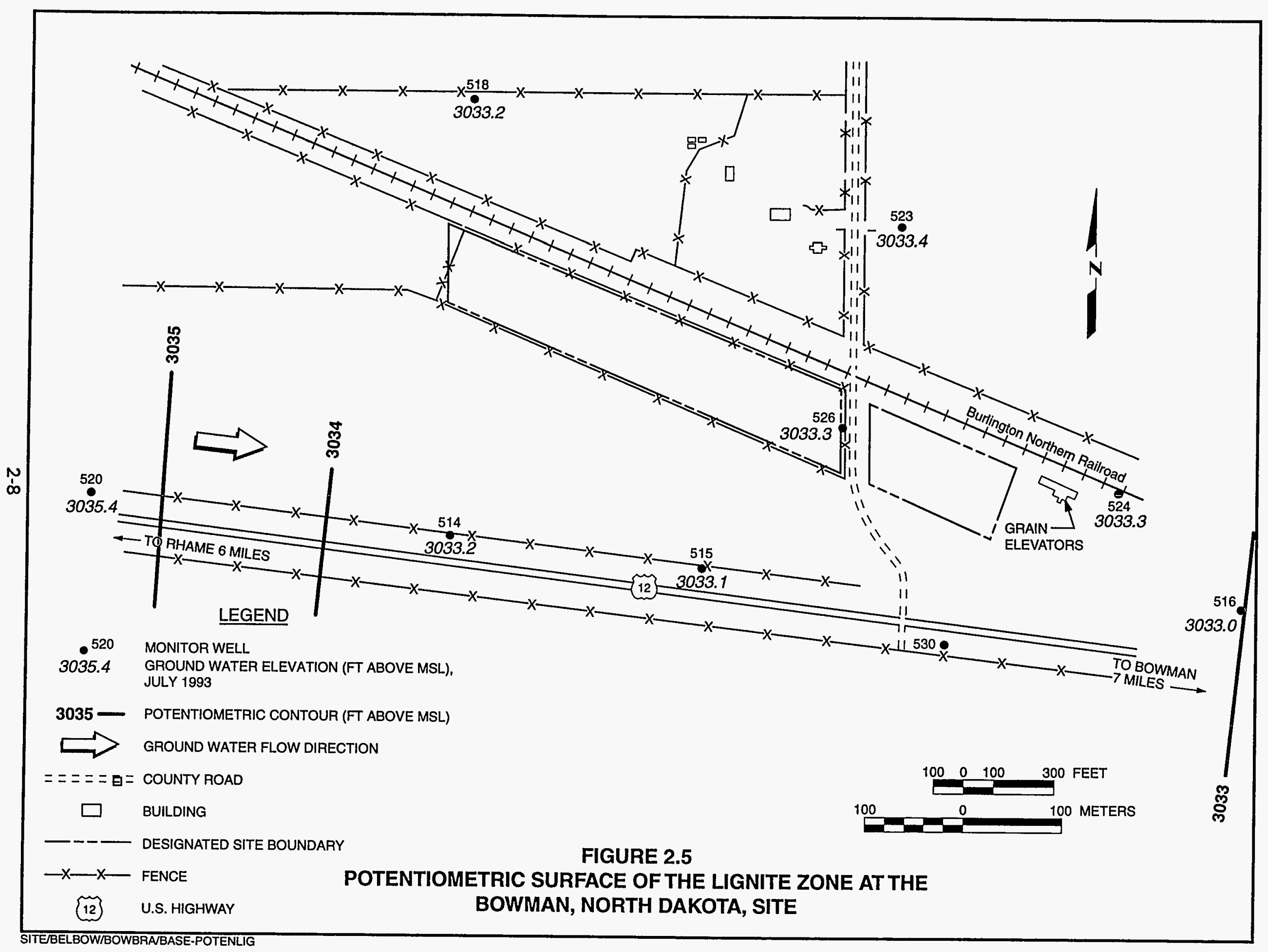


and estimated, unit-specific effective porosities. The upper zone was estimated as $4.6 \times 10^{-3} \mathrm{ft}$ per day $\left(1.6 \times 10^{-6} \mathrm{~cm} / \mathrm{s}\right)$, based on an average hydraulic conductivity of $0.23 \mathrm{ft}$ per day $\left(8.1 \times 10^{-5} \mathrm{~cm} / \mathrm{s}\right)$, an average hydraulic gradient of 0.004 , and an effective porosity of 0.20 . The lignite zone was estimated as $0.20 \mathrm{ft}$ per day $\left(7.1 \times 10^{-5} \mathrm{~cm} / \mathrm{s}\right)$, based on an average hydraulic conductivity of $10.2 \mathrm{ft}$ per day $\left(3.6 \times 10^{-3} \mathrm{~cm} / \mathrm{s}\right)$, an average hydraulic gradient of 0.001 , and an effective porosity of 0.05 . The lower zone was estimated as $3.8 \times 10^{-3} \mathrm{ft}$ per day $\left(1.3 \times 10^{-6} \mathrm{~cm} / \mathrm{s}\right)$, based on an average hydraulic conductivity of $0.15 \mathrm{ft}$ per day $\left(5.3 \times 10^{-5} \mathrm{~cm} / \mathrm{s}\right)$, an average gradient of 0.005 , and an effective porosity of 0.20 .

\subsubsection{Ground water monitoring}

Filtered ground water samples were collected from DOE monitor wells and from domestic wells in the vicinity of the Bowman processing site from 1986 through 1993 (Figures 2.6 and 2.7). These samples were analyzed for a full suite of inorganic parameters. The presence of organics was not investigated. Nonfiltered samples were collected from DOE monitor and domestic wells during the 1993 sampling round. Ground water quality data from specific monitor wells were used to qualitatively characterize background and on-site water quality in the site vicinity. Data from several domestic wells in the site vicinity were also evaluated qualitatively. Because of the physical and geochemical characteristics of the upper and lignite hydrogeologic zones, water quality in these two zones combined is representative of the shallow ground water system at the site. Water quality in the site vicinity is discussed in detail in Section 3.0.

\subsection{SURFACE WATER}

\subsubsection{Surface water hydrology}

The Bowman site is in a subbasin within the Spring Creek watershed (Figure 2.8). A dirt road accessing the farmhouse adjacent to the site bisects the site. Two tributary upland watersheds to Spring Creek exist in the site vicinity. The main portion of the designated site, west of the road, straddles a drainage divide between two minor tributaries (Figure 2.7). A broad drainage channel 3 to $6 \mathrm{ft}(1$ to $2 \mathrm{~m}$ ) below the general site elevation collects drainage from the main portion of the site. A railroad embankment borders the site to the north-northeast, and a highway embankment to the south-southeast. Therefore, drainage from the upland watershed tends to also travel along the broad drainage west of the site. Ponding sometimes occurs along this channel between the highway and the railroad tracks, creating a temporary surface water feature in the immediate site area. Wetland plants have developed along this drainage. However, excessive runoff drains through a culvert under U.S. Highway 12 and standing water is seldom present. The designated site is not subject to flooding and only discontinuous ephemeral portions of Spring Creek occur downstream of the site. 


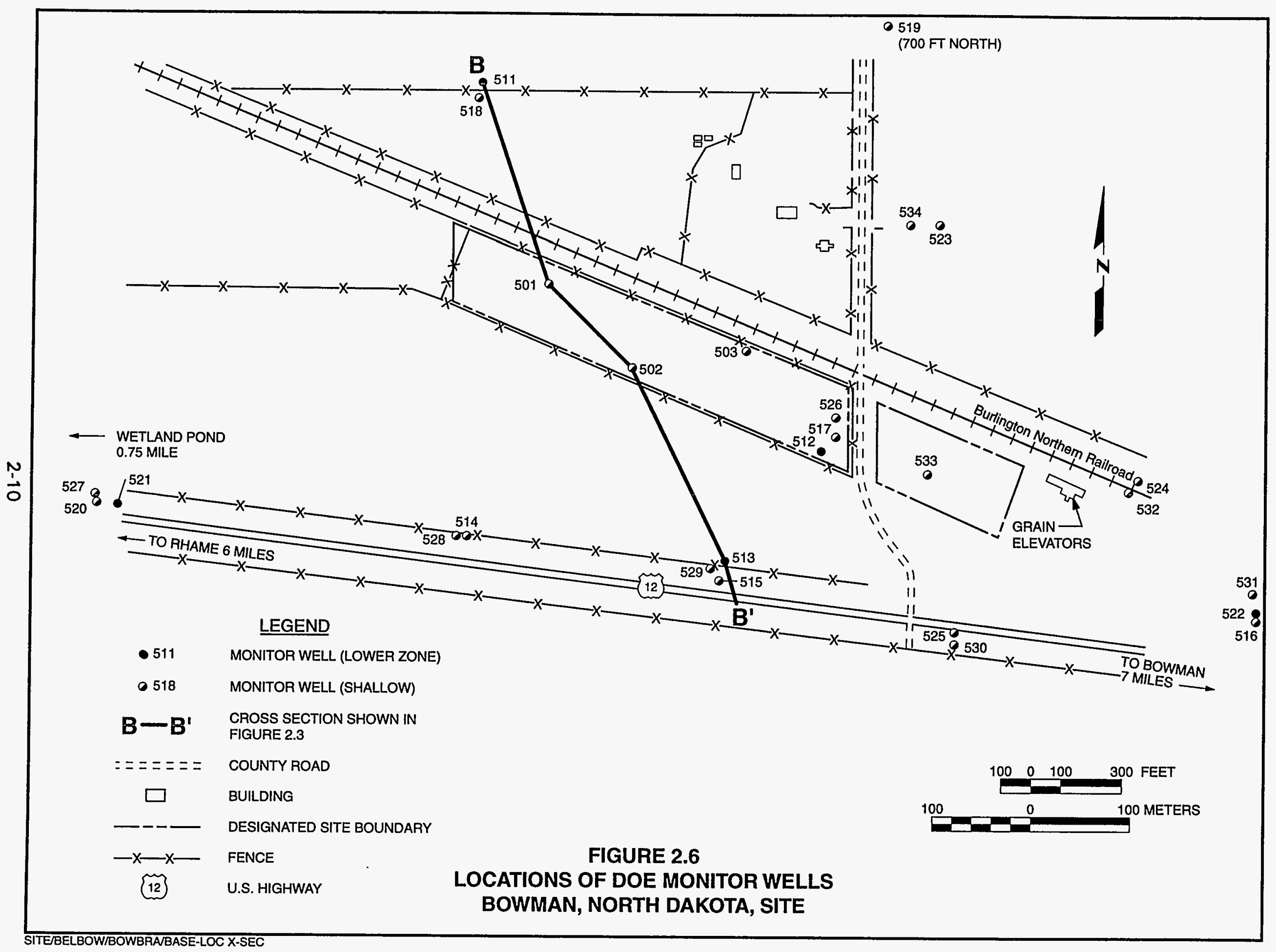




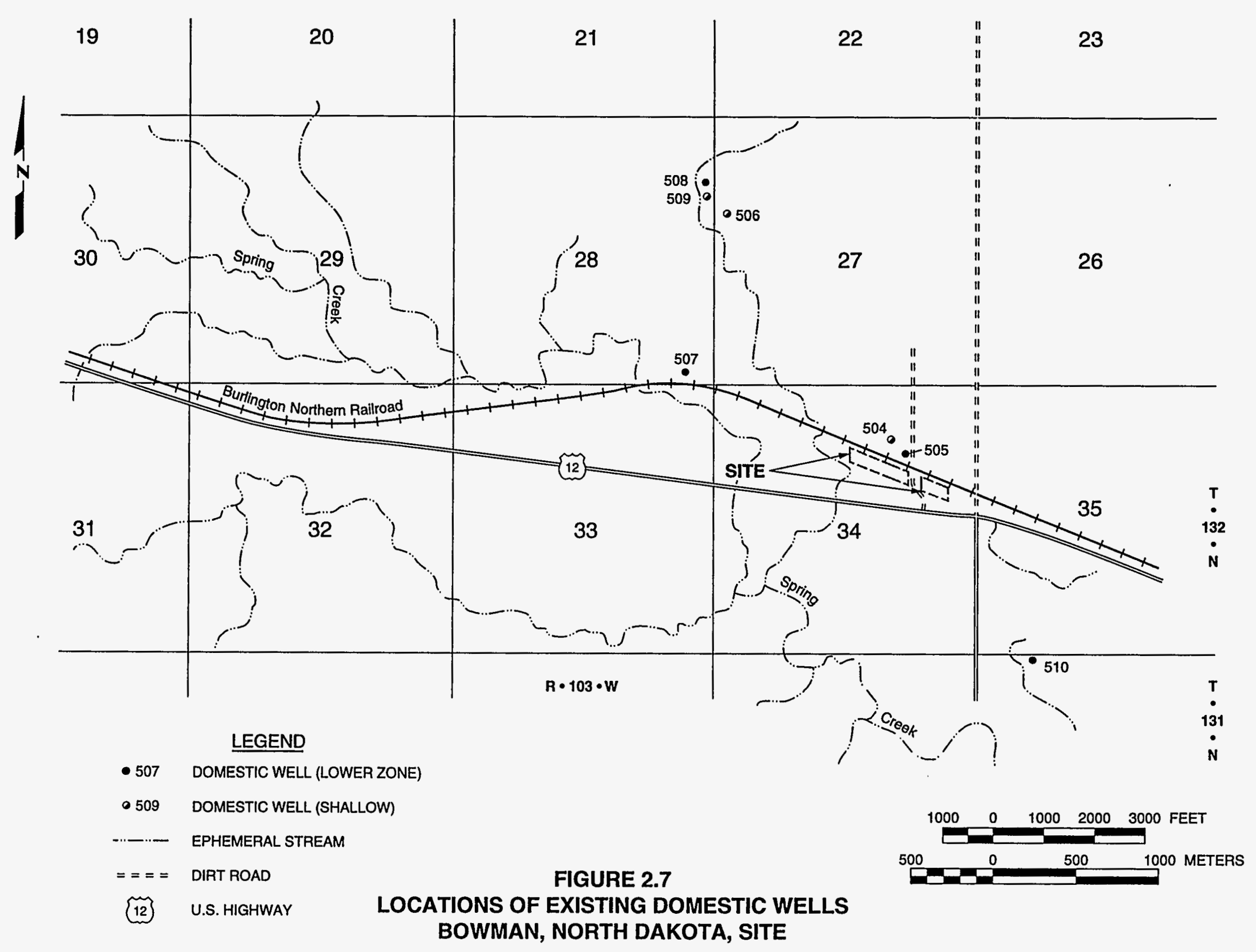




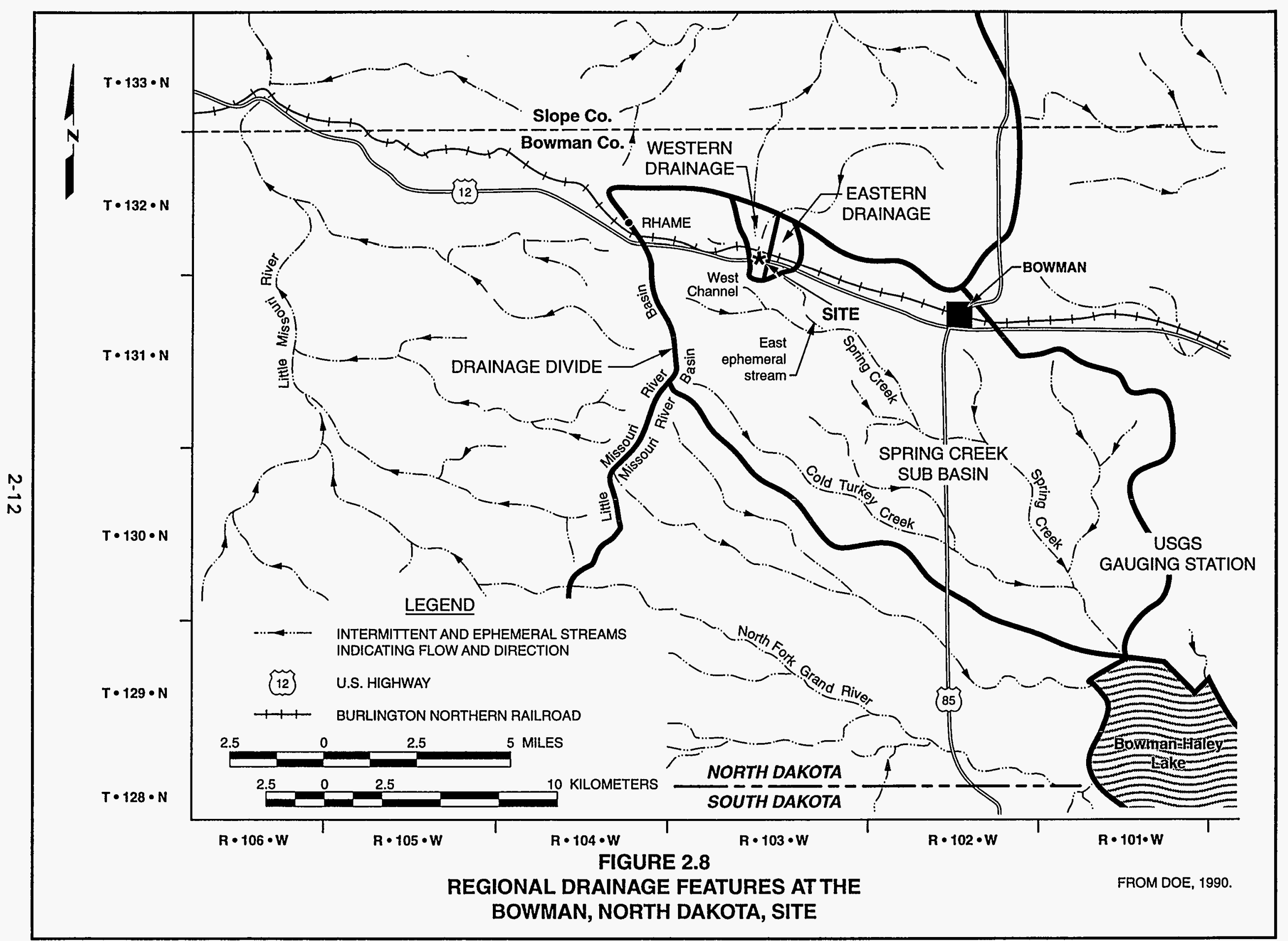


East-flowing surface drainage from the site is diverted by the road embankment and channeled south toward the highway. Puddling in this location is rare. Erosion from snowmelt or precipitation is not evident at the site.

Approximately $0.75 \mathrm{mi}(1.2 \mathrm{~km})$ west of the site along U.S. Highway 12 , another tributary to Spring Creek contains standing water year round. This area is a U.S. Army Corps of Engineers designated wetland. This wetland area has accumulated along the low lying areas on either side of the highway, and is fed by an upgradient artesian spring and surface runoff from the upgradient watershed. This wetland is isolated from surface runoff from the site and is hydraulically upgradient.

\subsubsection{Surface water monitoring}

Because permanent surface water features do not occur adjacent to the site itself, surface water monitoring data are limited to samples collected from temporarily available surface water features in the site vicinity. Samples were collected from these features near the site in single sampling events. Also, one surface water sample was collected from a wetland area $0.75 \mathrm{mi}(1.2 \mathrm{~km})$ west of the site and one from a ponded section of Spring Creek $2 \mathrm{mi}(3 \mathrm{~km})$ downgradient from the site (Figure 2.9); these are the nearest permanent surface water features to the site.

Surface water quality data represent independent samples from independent locations and can not be evaluated relationally. Samples were analyzed for inorganic parameters. Samples collected in 1993 were analyzed for uranium, chromium, lead, cadmium, molybdenum, and selenium only. Surficial sediment samples collected in conjunction with the 1993 surface water samples were analyzed for uranium, chromium, lead, cadmium, molybdenum, and selenium. Surface water quality and sediment quality data are presented in Section 7.0.

\section{$2.5 \quad$ LAND USE}

The Bowman UMTRA site is in Bowman County (population 4200), in southwestern North Dakota. Land use in the area is similar to land use throughout southwestern North Dakota. Land is privately owned and used mainly for agriculture. The nearest town is Bowman (population 1741 ) $7 \mathrm{mi}$ east of the processing site. Populations for most towns in this part of North Dakota do not exceed several thousand. Bowman consists mainly of residences and small businesses. The town was severely affected by declines in the oil industry starting in 1982. The population decreased approximately 25 percent between 1982 and 1993.

Portions of the designated site and land surrounding the site are privately owned by local residents, $S$. Soderstrom and $R$. Stearns. Land surrounding the site has been used for agricultural activities, including dry land farming and cattle grazing. The Burlington Northern Railroad borders the north edge of the site and cultivated fields and pasture surround the east, south, and west edges of the 


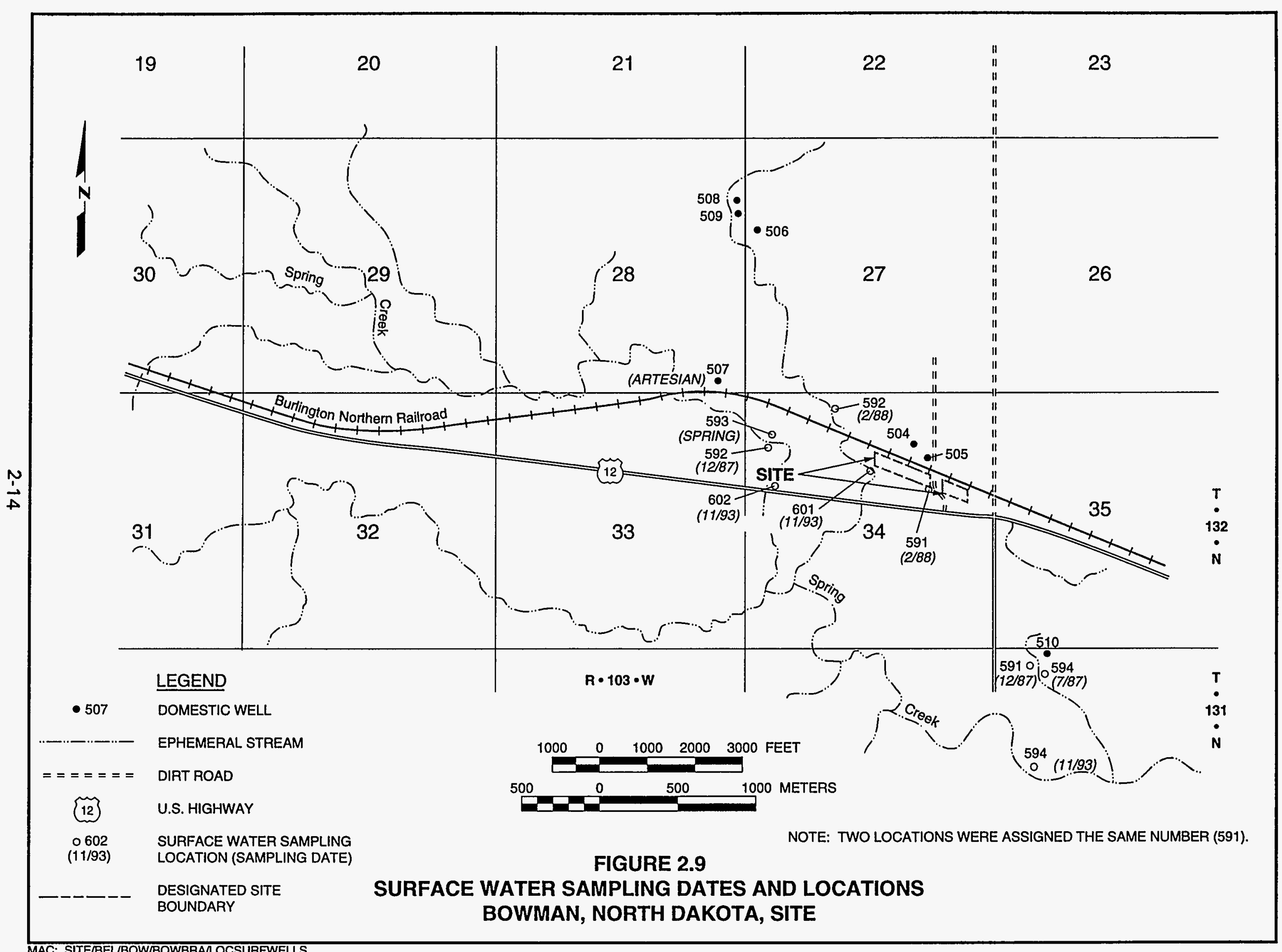


site. The property between the site and U.S. Highway 12 also contains a highway easement. A single residence is approximately $500 \mathrm{ft}$ north of the site, across the railroad tracks. The next nearest residence is more than $1 \mathrm{mi}(2 \mathrm{~km})$ away. A nonoperating grain elevator is adjacent to the eastern site boundary (Figure 2.2).

\section{WATER USE}

Currently, ground water is the only water source for this region of North Dakota. The town of Bowman receives water from a municipal water supply system from several deep wells (greater than $1000 \mathrm{ft}$ ) (greater than $300 \mathrm{~m}$ ) near town. The use and extent of privately owned wells within $1 \mathrm{mi}$ of the processing site were investigated through site visits, discussions with land owners, and historic records. Access to and private use of shallow ground water in the immediate site vicinity was the concern for this risk assessment.

Domestic wells 504 and 505 are adjacent to the site and could be impacted by site-related ground water contamination (Figure 2.7). Limited well depth information indicates domestic well 504 is screened in the upper zone while domestic well 505 is significantly deeper and is likely screened in the lower zone. These wells are used for all household purposes except drinking, because of the poor taste and odor of the ground water. Ground water contamination has not been identified in either of these wells. However, water from these wells could be impacted and an exposure pathway to contaminated ground water could be created through drinking or dermal exposure.

Domestic wells 506, 507, 508, 509, and 510, also sampled as part of the DOE monitoring program, are at least $1.5 \mathrm{mi}(2.4 \mathrm{~km})$ away from the site. Siterelated impacts to ground water quality in these wells is not expected. Domestic wells 506 and 509 are considered shallow wells, based on limited well depth information. No construction information is available for domestic well 507 but it is a flowing artesian well. Wells 508 and 510 are known to be deep wells likely extending into the lower zone. Ground water contamination has not been identified in any of these domestic wells. 


\subsection{EXTENT OF CONTAMINATION}

The potential magnitude and extent of contamination in ground water at the Bowman site related to lignite processing is presented in this section. The processing operation consisted of drying and burning lignite in a rotary kiln to concentrate uranium minerals associated with the lignite. This operation involved the combustion of organic material (lignite); chemical, metallurgical, or nuclear processes were not involved. Therefore, the only source of ground water contamination from the processing site is the potential leaching of precipitation through the raw lignite stockpiles or ash deposited on the ground surface during the burning or handling processes. Therefore, trace elements associated with metalliferous lignite might be expected in ground water.

Water level measurements and pumping test results indicate the subsurface hydrology is divided into three zones. However, the aquifer in the site vicinity is divided into two hydrochemical systems because of the geochemical similarities between the aquifer materials and the mixing of ground water. These systems are identified as the shallow system, composed of the lignite seam and associated sediments directly above also containing lignite stringers, and the lower system situated below the lignite. The hydrogeologic division is discussed in more detail in Section 3.1.2. The slight downward hydraulic gradient between these two hydrochemical systems results in potential recharge and contaminant transport.

Filtered ground water samples from DOE monitor wells and domestic wells in the site vicinity were collected from 1986 through 1993. These samples were analyzed for a full suite of inorganic parameters. One round of nonfiltered ground water samples were collected in 1993. Figure 2.6 shows monitor well locations; Figure 2.7 shows domestic well locations. Table 3.1 lists screened intervals, flow relationship, and the hydraulic relationship of monitor wells.

Available ground water quality data for filtered samples are used to characterize the extent of site-related ground water contamination and to define some of the geochemical processes occurring in ground water beneath the site, ground water quality beneath the site, and background ground water quality. Literature data on ground water quality in the southwestern region of North Dakota are applied in this evaluation. DOE monitor well data were evaluated quantitatively. Water quality data for domestic wells were evaluated for the presence of contamination. These data were used qualitatively in the evaluation of background water quality. Because well construction information was incomplete, domestic water quality was not evaluated quantitatively in association with DOE monitor well data. This information is used to determine contaminants of potential concern for risk to human health and the environment.

\subsection{BACKGROUND WATER QUALITY SUMMARY}

The presence of detectable concentrations of many trace elements in shallow ground water in southwestern North Dakota may initially give the impression of contamination by anthropogenic activities. However, this is not the case. Instead, this chemical signature represents a regional hydrochemical character 
Table 3.1 Monitor well information for the Bowman, North Dakota, site

\begin{tabular}{|c|c|c|c|}
\hline Location ID & $\begin{array}{c}\text { Screened interval } \\
(\mathrm{ft})\end{array}$ & Flow relationship & $\begin{array}{l}\text { Region of } \\
\text { completion }\end{array}$ \\
\hline $\begin{array}{l}\text { DOE monitor wel } \\
501 \\
502 \\
503 \\
511 \\
512 \\
513 \\
514 \\
515 \\
516 \\
517 \\
518 \\
519 \\
520 \\
521 \\
522 \\
523 \\
524 \\
525 \\
526 \\
527 \\
528 \\
529 \\
530 \\
531 \\
532 \\
533 \\
534\end{array}$ & $\begin{array}{l}22 \text { to } 32 \\
10 \text { to } 32 \\
17 \text { to } 32 \\
75 \text { to } 95 \\
75 \text { to } 95 \\
75 \text { to } 95 \\
30 \text { to } 40 \\
35 \text { to } 45 \\
30 \text { to } 40 \\
20 \text { to } 30 \\
35 \text { to } 45 \\
35 \text { to } 45 \\
50 \text { to } 60 \\
80 \text { to } 100 \\
80 \text { to } 100 \\
40 \text { to } 50 \\
30 \text { to } 40 \\
48 \text { to } 58 \\
40 \text { to } 50 \\
34 \text { to } 44 \\
15 \text { to } 25 \\
24 \text { to } 34 \\
34 \text { to } 44 \\
13 \text { to } 23 \\
15 \text { to } 25 \\
23 \text { to } 33 \\
25 \text { to } 35\end{array}$ & $\begin{array}{l}\text { On-site } \\
\text { On-site } \\
\text { On-site } \\
\text { Upgradient } \\
\text { On-site } \\
\text { Downgradient } \\
\text { Crossgradient } \\
\text { Downgradient } \\
\text { Downgradient } \\
\text { On-site } \\
\text { Upgradient } \\
\text { Upgradient } \\
\text { Upgradient } \\
\text { Upgradient } \\
\text { Downgradient } \\
\text { Upgradient } \\
\text { Downgradient } \\
\text { Downgradient } \\
\text { On-site } \\
\text { Upgradient } \\
\text { Crossgradient } \\
\text { Downgradient } \\
\text { Downgradient } \\
\text { Downgradient } \\
\text { Downgradient } \\
\text { Downgradient } \\
\text { Upgradient }\end{array}$ & $\begin{array}{l}\text { Shallow zone } \\
\text { Shallow zone } \\
\text { Shallow zone } \\
\text { Lower zone } \\
\text { Lower zone } \\
\text { Lower zone } \\
\text { Shallow zone } \\
\text { Shallow zone } \\
\text { Shallow zone } \\
\text { Shallow zone } \\
\text { Shallow zone } \\
\text { Shallow zone } \\
\text { Shallow zone } \\
\text { Lower zone } \\
\text { Lower zone } \\
\text { Shallow zone } \\
\text { Shallow zone } \\
\text { Shallow zone } \\
\text { Shallow zone } \\
\text { Shallow zone } \\
\text { Shallow zone } \\
\text { Shallow zone } \\
\text { Shallow zone } \\
\text { Shallow zone } \\
\text { Shallow zone } \\
\text { Shallow zone } \\
\text { Shallow zone }\end{array}$ \\
\hline $\begin{array}{c}\text { Domestic wells } \\
504 \\
505 \\
506 \\
507 \\
508 \\
509 \\
510\end{array}$ & $\begin{array}{l}\text { UK } \\
\text { UK } \\
\text { UK } \\
\text { UK } \\
\text { UK } \\
\text { UK } \\
\text { UK }\end{array}$ & $\begin{array}{l}\text { Upgradient } \\
\text { Upgradient } \\
\text { Upgradient } \\
\text { Upgradient } \\
\text { Upgradient } \\
\text { Upgradient } \\
\text { Downgradient }\end{array}$ & $\begin{array}{l}\text { Shallow zone } \\
\text { Lower zone } \\
\text { Shallow zone } \\
\text { UK } \\
\text { Lower zone } \\
\text { Shallow zone } \\
\text { Lower zone }\end{array}$ \\
\hline
\end{tabular}

UK - data not available or unknown. 
common to ground water in this region. Evidence for this phenomenon is discussed below.

\subsubsection{Regional background ground water quality}

Shallow groundwater quality in southwestern North Dakota is characterized by elevated trace elements and total dissolved solids (TDS), which are thought to be associated with metalliferous lignites in sediments of the Fort Union Group. Trace elements such as uranium, vanadium, cadmium, molybdenum, chromium, arsenic, selenium, and antimony are commonly associated with lignite and other sediments in southwestern North Dakota (Miller and Given, 1986; Roberts, 1994; Zeller and Schopf, 1959; Karner et al., 1986; Houghton et al., 1984; Duel and Annell, 1956; Moore et al., 1959; Nobel, 1972; Nakashima, 1992). Major ions (including calcium, potassium, sodium and magnesium) are also associated with lignites and sediments in the immediate vicinity (Miller and Given, 1986; Fulton and Jones, 1986; Fulton, 1989; Houghton et al., 1984; Karner et al., 1986; Ting and Jones, 1985). These elements are thought to be present as discrete mineral phases in sediments associated with lignite and complexed with humic matter in lignite. Lignite contains carboxylic and other chelated coordination complexes (Denson et al., 1959; Miller and Given, 1986; Karner et al., 1986; Nakashima, 1992) as sites for ion exchange (Karner et al, 1986; Miller and Given, 1986), reacting with ions in ground water. Houghton et al. $(1987 ; 1984)$ observed that sediments above a lignite seam in the Sentinel Butte Member of the Fort Union Formation in Stark County, North Dakota, contained elevated uranium. This uranium appeared to be more mobile than uranium in the lignite, suggesting the dissolution of mineral phases and exchangeable ions in lignites and associated sediments controls ground water chemistry, thereby explaining the presence of trace elements and major ions in shallow ground water in southwestern North Dakota.

The Sentinel Butte Member of the Fort Union Formation underlying the region of the Bowman processing site contains lignite seams and stringers. Uranium and other trace elements appear to be concentrated in and adjacent to these lignite beds and stringers and may modify the chemistry of ground water and infiltrating pore fluids. Roberts (1994) collected and interpreted data on uranium concentration in shallow ground water in southwestern North Dakota and in the Bowman vicinity. In 10 of the 24 ground water samples collected in Bowman County from wells with an average depth of $142 \mathrm{ft}$, uranium concentrations were greater than 20 micrograms per liter $(\mu \mathrm{g} / \mathrm{L}$ ) (greater than 0.02 milligrams per liter [mg/L]). Uranium concentrations were greater than $100 \mu \mathrm{g} / \mathrm{L}$ (greater than $0.1 \mathrm{mg} / \mathrm{L}$ ) in eight samples. The average uranium concentration in ground water accessed by these wells was $91 \mu \mathrm{g} / \mathrm{L}(0.09 \mathrm{mg} / \mathrm{L})$ (Roberts, 1994). Roberts (1994) also interpreted historical water quality data from 469 locations in Bowman County. These data show an average uranium concentration of $23 \mu \mathrm{g} / \mathrm{L}(0.02 \mathrm{mg} / \mathrm{L}): 95$ samples were greater than $20 \mu \mathrm{g} / \mathrm{L}$ (greater than $0.02 \mathrm{mg} / \mathrm{L}$ ) and 23 were greater than $100 \mu \mathrm{g} / \mathrm{L}$ (greater than $0.1 \mathrm{mg} / \mathrm{L}$ ). This evidence indicates uranium is widespread in shallow ground water in Bowman County, North Dakota. 


\subsubsection{Background ground water quality in the vicinity of the Bowman site}

For this risk assessment, background ground water quality in the Bowman site vicinity is considered representative of ground water quality at the site before ashing operations took place. Comparing on-site ground water quality to background ground water quality shows the extent of site-related ground water contamination.

Background ground water quality at the Bowman site varies with depth and lithology, suggesting there are two distinct hydrochemical systems in the underlying ground water. The shallow ground water system includes the lignite seam and the overlying claystone/sandy claystone layer that contains interbedded lignite stringers. The vertical extent is defined by the bottom of the deepest lignite seam up to the water table. Water quality in DOE background monitor wells 518 and 519 represents the shallow ground water system as a sodium-sulfate-bicarbonate type water characterized by trace elements at or slightly above the analytical detection limits, TDS concentrations of 800 to $4500 \mathrm{mg} / \mathrm{L}$, alkalinity of 300 to $500 \mathrm{mg} / \mathrm{L}$ calcium carbonate $\left(\mathrm{CaCO}_{3}\right)$, sulfate concentrations of 300 to $900 \mathrm{mg} / \mathrm{L}$, calcium concentrations of 40 to $100 \mathrm{mg} / \mathrm{L}$, and sodium concentrations of 200 to $300 \mathrm{mg} / \mathrm{L}$.

Water quality data for background domestic wells completed in the shallow ground water system were reviewed qualitatively. Domestic wells in the shallow system appear to have higher TDS and are comparable to the DOE wells in alkalinity and $\mathrm{pH}$ but have higher levels of dissolved metals. In addition to the metals observed in DOE background wells, zinc, cadmium, and silver were observed in domestic background wells. The water chemistry of these off-site wells reflects the geochemical heterogeneity of shallow ground water in the Bowman area (see Section 3.1.1). Because the domestic wells were not constructed to DOE standards, domestic ground water quality data were not used quantitatively in the evaluation of background ground water quality in the site vicinity. However, the commonality between the DOE and domestic background well data is the apparent presence of a wide suite of dissolved metals in shallow ground water.

Background water quality for the lower zone is represented by data from DOE monitor well 511. The lower zone is below the lignite seam, which serves as a hydraulic boundary. Ground water quality in the lower zone is also a sodiumsulfate-bicarbonate-type water but it is characterized by fewer detectable trace elements, TDS of approximately 1100 to $1900 \mathrm{mg} / \mathrm{L}$, sulfate concentrations of 400 to $800 \mathrm{mg} / \mathrm{L}$, sodium concentrations of 400 to $700 \mathrm{mg} / \mathrm{L}$, alkalinity of 400 to $600 \mathrm{mg} / \mathrm{L} \mathrm{CaCO}_{3}$, and $\mathrm{pH}$ ranging from 8.2 to 9.4 .

The distribution of trace elements in the subsurface at background locations in the Bowman site vicinity appears to fit the following conceptual model (assuming a downward vertical hydraulic gradient throughout most of the area). As oxidizing precipitation infiltrates the subsurface, trace elements that have accumulated in the overlying sediments through oxidation and dissolution of 
unstable sulfide phases and organic material are mobilized in ground water. These trace elements attenuate as they react with sediments down the flow path. As ground water eventually flows into the lignite zone, most trace elements that remain complexed with the lignite are attenuated from ground water. Downs (DOE, 1991) corroborates this model, noting a decrease of select trace elements with depth from several background borehole locations at the Bowman site.

\subsection{MAGNITUDE AND EXTENT OF SITE-RELATED CONTAMINATION}

The following potential sources of ground water contamination at the Bowman site resulted from the lignite burning process:

- Water leached through stockpiled raw lignite prior to burning.

- Ash and dust potentially released to the atmosphere during the process.

- Wind and erosional dispersion, with subsequent leaching of water through this soil contamination.

Lignite burning was the only process conducted at the Bowman site. Metals and ions expected in ground water in association with lignite and lignite burning are uranium, vanadium, chromium, lead, sulfate, selenium, sodium, antimony, molybdenum, and silver. The presence of organic constituents related to the burning process was not investigated. Any nonore-related contaminants detected in ground water could be caused by past or present agricultural activities in the site vicinity.

Soil contamination related to the ashing process extends beyond the designated site boundary (Figure 2.2). Soil pore fluids collected from on-site DOE suction lysimeters show maximum concentrations of the indicator parameters: molybdenum $(0.6 \mathrm{mg} / \mathrm{L})$, selenium $(0.4 \mathrm{mg} / \mathrm{L})$, chromium $(0.2 \mathrm{mg} / \mathrm{L})$, uranium $(1.5 \mathrm{mg} / \mathrm{L})$, sulfate $(13,800 \mathrm{mg} / \mathrm{L})$, and magnesium $(1500 \mathrm{mg} / \mathrm{L})$. Although no comparison soil pore fluid background data are available, it appears that the parameters indicative of the ashing process are present in the vadose zone beneath the site. Concentrations of these indicator parameters are greater in shallow ground water beneath the site. Substantial concentrations are not detected in the deeper lower zone ground water system. This suggests that dilution and chemical attenuation processes are occurring during infiltration. Contaminants concentrations in ground water are not expected to increase since processing activities are concluded and soil contamination is to be removed under the UMTRA Surface Project. Potential contaminants movement from the shallow zone into the lower zone is discussed in Section 3.2.2. Further assessment of the magnitude and extent of these indicator parameters at and around the Bowman site is presented below. 


\subsubsection{Site-related contamination in shallow ground water}

Table 3.2 summarizes constituents in shallow ground water, comparing background with on-site locations. Data from on-site monitor wells 502, 503, and 517 represent the highest constituent levels in shallow ground water

(Figure 2.6). The ground water quality data suggest the presence of site-related contamination. Maximum on-site concentrations of the indicator parameters are uranium at $0.4 \mathrm{mg} / \mathrm{L}$, vanadium at $0.3 \mathrm{mg} / \mathrm{L}$, selenium at $0.2 \mathrm{mg} / \mathrm{L}$, and molybdenum at $0.7 \mathrm{mg} / \mathrm{L}$. These constituents are consistently higher than background levels.

Tracking uranium concentrations in shallow ground water downgradient and crossgradient from the site as indicators of the possible extent of site-related contamination does not clearly indicate migration of contamination off the site. Uranium concentrations vary among these off-site wells. Uranium appears to be present above background levels at many of these locations but at much lower levels than on-site. The maximum uranium concentrations in downgradient DOE monitor wells 530 and 531 are 0.036 and $0.048 \mathrm{mg} / \mathrm{L}$, respectively. In crossgradient DOE monitor wells 528 and 529 , the maximum uranium concentrations are 0.061 and $0.038 \mathrm{mg} / \mathrm{L}$, respectively. These maximums are equal to or greater than the maximum defined for DOE background monitor wells $(0.007 \mathrm{mg} / \mathrm{L})$. However, these off-site levels are within the range identified for regional background in southwestern North Dakota. The east-west trending ore zone delineated by Bauer and Land (1976) may account for the variably elevated levels of uranium in ground water in select wells in the site vicinity. Given the naturally high uranium concentrations in regional ground water (Roberts, 1994), it is difficult to distinguish potential site-related uranium in ground water south and southwest of the site from naturally occurring uranium in this area. The assessment of uranium concentrations off the site is based on a limited data set and well coverage along the flow path away from the site. However, the variable uranium concentrations are within the range of regional background, raising the question of whether it is potentially site related. Furthermore, levels of other parameters indicative of site-related contamination (i.e., vanadium, selenium, arsenic, and molybdenum) are much lower at these off-site locations. This distinct drop in concentrations suggests contamination is not migrating away and remains localized at the site.

On-site levels of the major cations and anions, including calcium, magnesium, sodium, phosphate, potassium, sulfate, and chloride, appear to be elevated above background levels (Table 3.2). Downgradient DOE monitor well concentrations are comparable or, for some constituents, higher than on-site concentrations. Chloride is lower in off-site wells. Based on well screen information for several of these off-site wells, shallow ground water appears to have higher TDS and a greater concentration of elements near the top of the water table, with concentrations decreasing with depth (Figure 3.1). This suggests the presence of cations and anions in shallow ground water off-site is probably not site-related but may be attributed to the position of the well screen at the water table. Houghton et al. (1984) found the aquifer matrix at the top 
Table 3.2 Summary of filtered water quality in the shallow ground water system near Bowman, North Dakota, 1986-1993

\begin{tabular}{|c|c|c|c|c|}
\hline \multirow[b]{2}{*}{ Parameter ${ }^{\mathbf{b}}$} & \multirow[b]{2}{*}{$\begin{array}{c}\text { Frequency of } \\
\text { detection }\end{array}$} & \multicolumn{3}{|c|}{ Observed concentrations } \\
\hline & & $\begin{array}{c}\text { Minimum } \\
(\mathrm{mg} / \mathrm{L})\end{array}$ & $\begin{array}{c}\text { Median }^{8} \\
\text { (mg/L) }\end{array}$ & $\begin{array}{c}\text { Maximum } \\
(\mathrm{mg} / \mathrm{L})\end{array}$ \\
\hline \multicolumn{5}{|l|}{ Aluminum } \\
\hline Background & $5 / 15$ & $<0.01$ & $<0.10$ & 0.17 \\
\hline On-site & $12 / 19$ & $<0.05$ & 0.20 & 0.33 \\
\hline \multicolumn{5}{|l|}{ Ammonium } \\
\hline Background & $12 / 17$ & $<0.10$ & 0.12 & 1.2 \\
\hline On-site & $6 / 18$ & $<0.10$ & $<0.10$ & 0.3 \\
\hline \multicolumn{5}{|l|}{ Antimony } \\
\hline Background & $6 / 15$ & $<0.003$ & $<0.003$ & 0.091 \\
\hline On-site & $8 / 15$ & $<0.003$ & 0.015 & 0.52 \\
\hline \multicolumn{5}{|l|}{ Arsenic } \\
\hline Background & $2 / 17$ & $<0.001$ & $<0.005$ & 0.005 \\
\hline On-site & $8 / 20$ & 0.002 & $<0.009$ & 0.018 \\
\hline \multicolumn{5}{|l|}{ Barium } \\
\hline Background & $5 / 15$ & $<0.01$ & $<0.10$ & 0.10 \\
\hline On-site & $8 / 19$ & $<0.01$ & $<0.10$ & 0.10 \\
\hline \multicolumn{5}{|l|}{ Beryllium } \\
\hline Background & $0 / 5$ & $<0.005$ & $<0.005$ & $<0.010$ \\
\hline On-site & $0 / 4$ & $<0.005$ & $<0.005$ & $<0.005$ \\
\hline \multicolumn{5}{|l|}{ Boron } \\
\hline Background & $14 / 14$ & 0.39 & 0.80 & 0.90 \\
\hline On-site & $19 / 19$ & 0.30 & 1.20 & 1.71 \\
\hline \multicolumn{5}{|l|}{ Bromide } \\
\hline Background & $0 / 4$ & $<0.10$ & $<0.10$ & $<0.10$ \\
\hline On-site (517) & $2 / 2$ & 0.20 & 0.26 & 0.31 \\
\hline \multicolumn{5}{|l|}{ Cadmium } \\
\hline Background & $6 / 17$ & $<0.000$ & $<0.001$ & 0.009 \\
\hline On-site & $4 / 20$ & $<0.000$ & $<0.001$ & 0.059 \\
\hline
\end{tabular}


Table 3.2 Summary of filtered water quality in the shallow ground water system near Bowman, North Dakota, 1986-1993 (Continued)

\begin{tabular}{|c|c|c|c|c|}
\hline \multirow[b]{2}{*}{ Parameter $^{\mathbf{b}}$} & \multirow[b]{2}{*}{$\begin{array}{l}\text { Frequency of } \\
\text { detection }\end{array}$} & \multicolumn{3}{|c|}{ Observed concentrations } \\
\hline & & $\begin{array}{c}\text { Minimum } \\
(\mathrm{mg} / \mathrm{L})\end{array}$ & $\begin{array}{l}\text { Median }^{8} \\
\text { (mg/L) }\end{array}$ & $\begin{array}{c}\text { Maximum } \\
\text { (mg/L) }\end{array}$ \\
\hline \multicolumn{5}{|l|}{ Calcium } \\
\hline Background & $17 / 17$ & 47 & 71 & 104 \\
\hline On-site & $20 / 20$ & 92 & 253 & 360 \\
\hline \multicolumn{5}{|l|}{ Chloride } \\
\hline Background & $15 / 15$ & 1.5 & 5.0 & 8.9 \\
\hline On-site & $19 / 19$ & 15 & 51 & 154 \\
\hline \multicolumn{5}{|l|}{ Chromium } \\
\hline Background & $7 / 17$ & $<0.01$ & $<0.01$ & 0.04 \\
\hline On-site & $12 / 20$ & $<0.01$ & 0.03 & 0.17 \\
\hline \multicolumn{5}{|l|}{ Cobalt } \\
\hline Background & $0 / 5$ & $<0.05$ & $<0.05$ & $<0.05$ \\
\hline On-site & $0 / 4$ & $<0.05$ & $<0.05$ & $<0.05$ \\
\hline \multicolumn{5}{|l|}{ Copper } \\
\hline Background & $3 / 15$ & $<0.01$ & $<0.02$ & 0.02 \\
\hline On-site & $11 / 19$ & $<0.01$ & $<0.02$ & 0.06 \\
\hline \multicolumn{5}{|l|}{ Cyanide } \\
\hline Background & $0 / 4$ & $<0.01$ & $<0.01$ & $<0.01$ \\
\hline On-site & $0 / 4$ & $<0.01$ & $<0.01$ & $<0.01$ \\
\hline \multicolumn{5}{|l|}{ Fluoride } \\
\hline Background & $15 / 15$ & 0.1 & 0.3 & 0.5 \\
\hline On-site & $19 / 19$ & 0.5 & 0.8 & 1.3 \\
\hline \multicolumn{5}{|l|}{ Iron } \\
\hline Background & $17 / 17$ & 0.14 & 0.33 & 2.7 \\
\hline On-site & $13 / 20$ & $<0.03$ & 0.06 & 3.4 \\
\hline \multicolumn{5}{|l|}{ Lead } \\
\hline Background & $4 / 17$ & $<0.001$ & $<0.01$ & 0.05 \\
\hline On-site & $7 / 20$ & $<0.003$ & $<0.01$ & 0.38 \\
\hline
\end{tabular}


Table 3.2 Summary of filtered water quality in the shallow ground water system near Bowman, North Dakota, 1986-1993 (Continued)

\begin{tabular}{|c|c|c|c|c|}
\hline \multirow[b]{2}{*}{ Parameter $^{\mathbf{b}}$} & \multirow[b]{2}{*}{$\begin{array}{c}\text { Frequency of } \\
\text { detection }\end{array}$} & \multicolumn{3}{|c|}{ Observed concentrations } \\
\hline & & $\begin{array}{c}\text { Minimum } \\
\text { (mg/L) }\end{array}$ & $\begin{array}{c}\text { Median }^{a} \\
\text { (mg/L) }\end{array}$ & $\begin{array}{c}\text { Maximum } \\
\text { (mg/L) }\end{array}$ \\
\hline \multicolumn{5}{|l|}{ Magnesium } \\
\hline Background & $17 / 17$ & 4 & 55 & 79 \\
\hline On-site & $20 / 20$ & 40 & 405 & 630 \\
\hline \multicolumn{5}{|l|}{ Manganese } \\
\hline Background & $17 / 17$ & 0.45 & 0.61 & 0.8 \\
\hline On-site & $19 / 20$ & $<0.01$ & 0.05 & 1.2 \\
\hline \multicolumn{5}{|l|}{ Mercury } \\
\hline Background & $1 / 13$ & $<0.0002$ & $<0.0002$ & 0.0002 \\
\hline On-site & $2 / 16$ & $<0.0002$ & $<0.0002$ & 0.0005 \\
\hline \multicolumn{5}{|l|}{ Molybdenum } \\
\hline Background & $7 / 17$ & $<0.010$ & $<0.01$ & 0.07 \\
\hline On-site (517) & $8 / 8$ & 0.36 & 0.57 & 0.68 \\
\hline \multicolumn{5}{|l|}{ Nickel } \\
\hline Background & $4 / 13$ & 0.02 & $<0.04$ & $<0.04$ \\
\hline On-site & $7 / 14$ & $<0.04$ & $<0.07$ & 0.14 \\
\hline \multicolumn{5}{|l|}{ Nitrate } \\
\hline Background & $6 / 15$ & $<0.1$ & $<1$ & 2 \\
\hline On-site (517) & $7 / 7$ & 66 & 96 & 130 \\
\hline \multicolumn{5}{|l|}{ Phosphate } \\
\hline Background & $4 / 11$ & $<0.1$ & $<0.1$ & 0.4 \\
\hline On-site & $10 / 13$ & $<0.1$ & 0.2 & 0.9 \\
\hline \multicolumn{5}{|l|}{ Potassium } \\
\hline Background & $17 / 17$ & 6 & 8 & 13 \\
\hline On-site & $20 / 20$ & 14 & 35 & 52 \\
\hline \multicolumn{5}{|l|}{ Selenium } \\
\hline Background & $4 / 17$ & $<0.001$ & $<0.005$ & 0.14 \\
\hline On-site & $17 / 20$ & $<0.005$ & 0.069 & 0.18 \\
\hline
\end{tabular}


Table 3.2 Summary of filtered water quality in the shallow ground water system near Bowman, North Dakota, 1986-1993 (Continued)

\begin{tabular}{|c|c|c|c|c|}
\hline \multirow[b]{2}{*}{ Parameter $^{b}$} & \multirow[b]{2}{*}{$\begin{array}{c}\text { Frequency of } \\
\text { detection }^{\mathrm{c}}\end{array}$} & \multicolumn{3}{|c|}{ Observed concentrations } \\
\hline & & $\begin{array}{c}\text { Minimum } \\
\text { (mg/L) }\end{array}$ & $\begin{array}{c}\text { Median }^{8} \\
\text { (mg/L) }\end{array}$ & $\begin{array}{c}\text { Maximum } \\
\text { (mg/L) }\end{array}$ \\
\hline \multicolumn{5}{|l|}{ Silver } \\
\hline Background & $0 / 15$ & $<0.01$ & $<0.01$ & $<0.01$ \\
\hline On-site & $8 / 19$ & $<0.01$ & $<0.01$ & 0.03 \\
\hline \multicolumn{5}{|l|}{ Sodium } \\
\hline Background & $17 / 17$ & 156 & 241 & 323 \\
\hline On-site & $20 / 20$ & 443 & 915 & 1740 \\
\hline \multicolumn{5}{|l|}{ Strontium } \\
\hline Background & $15 / 15$ & 0.4 & 0.6 & 0.8 \\
\hline On-site & $19 / 19$ & 1.2 & 3.0 & 4.6 \\
\hline \multicolumn{5}{|l|}{ Sulfate } \\
\hline Background & $17 / 17$ & 321 & 540 & 910 \\
\hline On-site & $20 / 20$ & 1420 & 3195 & 6200 \\
\hline \multicolumn{5}{|l|}{ Suifide } \\
\hline Background & $1 / 12$ & $<0.1$ & $<0.1$ & 1.0 \\
\hline On-site & $1 / 16$ & $<0.1$ & $<0.1$ & 0.3 \\
\hline \multicolumn{5}{|l|}{ Thallium } \\
\hline Background & $0 / 5$ & $<0.005$ & $<0.01$ & $<0.1$ \\
\hline On-site & $1 / 4$ & $<0.005$ & $<0.005$ & 0.1 \\
\hline \multicolumn{5}{|l|}{ Tin } \\
\hline Background & $1 / 5$ & $<0.005$ & $<0.005$ & 0.008 \\
\hline On-site & $1 / 4$ & $<0.005$ & $<0.025$ & 0.030 \\
\hline \multicolumn{5}{|l|}{ Uranium } \\
\hline Background & $13 / 17$ & $<0.001$ & 0.004 & 0.007 \\
\hline On-site & $14 / 14$ & 0.25 & 0.31 & 0.39 \\
\hline \multicolumn{5}{|l|}{ Vanadium } \\
\hline Background & $4 / 17$ & $<0.01$ & $<0.01$ & 0.02 \\
\hline On-site & $16 / 20$ & $<0.01$ & 0.05 & 0.40 \\
\hline
\end{tabular}


Table 3.2 Summary of filtered water quality in the shallow ground water system near Bowman, North Dakota, 1986-1993 (Concluded)

\begin{tabular}{|c|c|c|c|c|}
\hline \multirow[b]{2}{*}{ Parameter $^{b}$} & \multirow[b]{2}{*}{$\begin{array}{c}\text { Frequency of } \\
\text { detection }\end{array}$} & \multicolumn{3}{|c|}{ Observed concentrations } \\
\hline & & $\begin{array}{c}\text { Minimum } \\
\text { (mg/L) }\end{array}$ & $\begin{array}{l}\text { Median }^{\text {a }} \\
\text { (mg/L) }\end{array}$ & $\begin{array}{c}\text { Maximum } \\
\text { (mg/L) }\end{array}$ \\
\hline \multicolumn{5}{|l|}{ Zinc } \\
\hline Background & $9 / 15$ & $<0.005$ & 0.008 & 0.078 \\
\hline On-site & $14 / 19$ & $<0.005$ & 0.017 & 0.073 \\
\hline & & \multicolumn{3}{|c|}{ (pCi/L) } \\
\hline \multicolumn{5}{|l|}{ Lead-210 } \\
\hline Background & $10 / 10$ & 0.0 & 0.3 & 2.4 \\
\hline On-site & $16 / 16$ & 0.1 & 1.3 & 4.1 \\
\hline \multicolumn{5}{|l|}{ Polonium-210 } \\
\hline Background & $10 / 10$ & 0.0 & 0.2 & 0.5 \\
\hline On-site & $16 / 16$ & 0.0 & 0.2 & 0.8 \\
\hline \multicolumn{5}{|l|}{ Radium-226 } \\
\hline Background & $13 / 13$ & 0.0 & 0.2 & 0.7 \\
\hline Off-site & $9 / 9$ & 1.3 & 2.4 & 4.3 \\
\hline \multicolumn{5}{|l|}{ Thorium-230 } \\
\hline Background & $11 / 11$ & 0.0 & 0.2 & 0.6 \\
\hline On-site & $16 / 16$ & 0.0 & 0.3 & 1.6 \\
\hline
\end{tabular}

a The 50th percentile of the data.

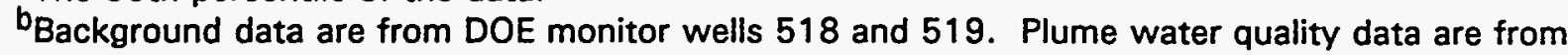
on-site DOE monitor wells 502, 503, and 517 (combined) unless otherwise indicated.

Number of water samples with detectable concentrations/total number of samples. 


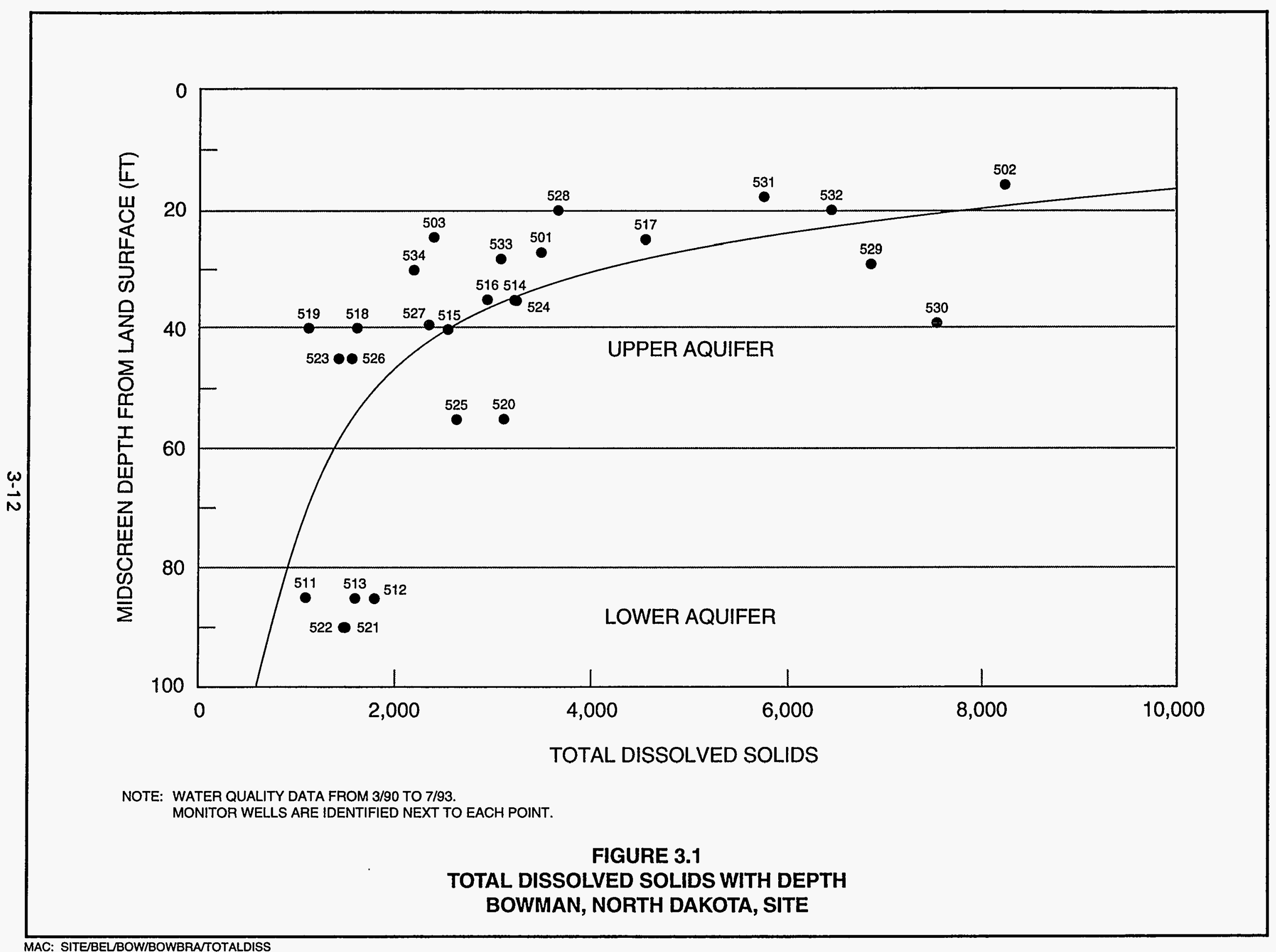


of the water table has more exchangeable cations then underlying aquifer materials, which may also explain the high TDS near the water table. Finally, the lateral heterogeneity in permeability of the aquifer matrix and residence time of ground water may also account for the distribution of elements in ground water downgradient from the site.

The nitrate, chloride, and phosphate in ground water are unrelated to the lignite burning process. Chloride may be present as a by-product of road salting. Nitrate and phosphate are likely associated with agricultural activities as an oxidation product of ammonia-, ammonium-, and phosphorous-containing fertilizers commonly used in the area.

\subsubsection{Site-related contamination in the lower zone}

Table $\mathbf{3 . 3}$ summarizes on-site ground water quality in the lower zone, comparing it to background ground water quality for the lower zone and to on-site shallow ground water quality. Data from DOE monitor wells 511, 513, 521, 522 loffsite) and DOE monitor well 512 (on-site) were used in the comparison. Molybdenum, arsenic, vanadium, and uranium are at or just slightly above the analytical detection limit in ground water in the lower zone, sampled from onsite monitor well 512. This does not appear to represent site-related impacts to the lower zone beneath the site. Furthermore, trace element concentrations in ground water in off-site monitor wells 511, 513,521, 522 are comparable to concentrations of trace elements in on-site monitor well 512. This consistency in trace element levels implies the lower zone is isolated from contamination in the shallow zone, regardless of the slight downward vertical hydraulic gradient identified for the site. Geochemical isolation between the two ground water systems may be due to the following: 1) groundwater flow in the lignite is several orders of magnitude greater than the lower zone and so will entrain and transport groundwater infiltrating from above, and 2) the lignite acts as an effective geochemical barrier (DOE, 1991), especially with respect to redoxsensitive trace elements (i.e., uranium, vanadium, molybdenum, and selenium). Both of these mechanisms appear to protect the underlying ground water resources.

\section{Summary}

Soils in the Bowman site vicinity are contaminated from the lignite ashing process and ground water beneath the site is also impacted. Uranium in shallow ground water downgradient from the site does not appear to be related to site contamination but instead represents natural concentrations. Ground water in the lower zone is not impacted by site-related contamination and likely is protected by the hydraulic and physicochemical characteristics of the lignite seam. The sorption potential for contaminants is greatest in the shallow system, where contamination is present; therefore, dispersal of contaminated ground water is limited to the area beneath and immediately adjacent to the site. Apparently, elevated TDS levels both on and off the site are not related to ashing activities. Overall, contamination does not appear to be moving off the 
Table 3.3 Summary of filtered water quality in the lower zone near Bowman, North Dakota (1986-1990)

\begin{tabular}{|c|c|c|c|c|}
\hline \multirow[b]{2}{*}{ Parameter ${ }^{\mathbf{b}}$} & \multirow[b]{2}{*}{$\begin{array}{l}\text { Frequency of } \\
\text { detectionc }\end{array}$} & \multicolumn{3}{|c|}{ Observed concentrations } \\
\hline & & $\begin{array}{l}\text { Minimum } \\
\text { (mg/L) }\end{array}$ & $\begin{array}{l}\text { Median }^{\mathrm{a}} \\
\text { (mg/L) }\end{array}$ & $\begin{array}{c}\text { Maximum } \\
(\mathrm{mg} / \mathrm{L})\end{array}$ \\
\hline \multicolumn{5}{|l|}{ Arsenic } \\
\hline Background & $2 / 6$ & $<0.001$ & d & 0.003 \\
\hline On-site & $3 / 6$ & 0.002 & d & 0.003 \\
\hline Off-site & $2 / 6$ & $<0.001$ & d & 0.001 \\
\hline On-site, shallow zone & $8 / 20$ & 0.002 & $<0.009$ & 0.018 \\
\hline \multicolumn{5}{|l|}{ Bromide } \\
\hline Background & $0 / 1$ & & $<0.10$ & \\
\hline On-site & $1 / 1$ & & 0.20 & \\
\hline Off-site & $1 / 3$ & $<0.10$ & $<0.10$ & 0.10 \\
\hline On-site, shallow zone & $2 / 2$ & 0.20 & 0.26 & 0.31 \\
\hline \multicolumn{5}{|l|}{ Boron } \\
\hline Background & $6 / 6$ & 0.37 & 0.40 & 0.42 \\
\hline On-site & $6 / 6$ & 0.50 & 0.53 & 0.66 \\
\hline Off-site & $10 / 10$ & 0.28 & 0.42 & 0.50 \\
\hline On-site, shallow zone & $19 / 19$ & 0.30 & 1.20 & 1.71 \\
\hline \multicolumn{5}{|l|}{ Calcium } \\
\hline Background & $6 / 6$ & 1.8 & 2.2 & 3.0 \\
\hline On-site & $6 / 6$ & 3.9 & 5.0 & 7.5 \\
\hline Off-site & $10 / 10$ & 3.2 & 4.3 & 9.1 \\
\hline On-site, shallow zone & $20 / 20$ & 92 & 253 & 360 \\
\hline \multicolumn{5}{|l|}{ Chloride } \\
\hline Background & $6 / 6$ & 1.5 & 3.4 & 4.9 \\
\hline On-site & $6 / 6$ & 4.5 & 5.1 & 7.4 \\
\hline Off-site & $10 / 10$ & 3.9 & 5.2 & 7.0 \\
\hline On-site, shallow zone & $19 / 19$ & 15 & 51 & 154 \\
\hline \multicolumn{5}{|l|}{ Fluoride } \\
\hline Background & $5 / 6$ & $<0.10$ & 0.19 & 0.22 \\
\hline On-site & $6 / 6$ & 0.30 & 0.36 & 0.50 \\
\hline Off-site & $10 / 10$ & 0.10 & 0.30 & 0.37 \\
\hline On-site, shallow zone & $19 / 19$ & 0.52 & 0.80 & 1.30 \\
\hline
\end{tabular}


Table 3.3 Summary of filtered water quality in the lower zone near Bowman, North Dakota (1986-1990) (Continued)

\begin{tabular}{|c|c|c|c|c|}
\hline \multirow[b]{2}{*}{ Parameter $^{\mathbf{b}}$} & \multirow[b]{2}{*}{$\begin{array}{c}\text { Frequency of } \\
\text { detectionc }\end{array}$} & \multicolumn{3}{|c|}{ Observed concentrations } \\
\hline & & $\begin{array}{c}\text { Minimum } \\
(\mathrm{mg} / \mathrm{L})\end{array}$ & $\begin{array}{l}\text { Mediana } \\
\text { (mg/L) }\end{array}$ & $\begin{array}{c}\text { Maximum } \\
(\mathrm{mg} / \mathrm{L})\end{array}$ \\
\hline \multicolumn{5}{|l|}{ Magnesium } \\
\hline Background & $6 / 6$ & 0.7 & 0.8 & 1.1 \\
\hline On-site & $6 / 6$ & 1.4 & 2.0 & 2.8 \\
\hline Off-site & $10 / 10$ & 1.4 & 1.7 & 3.0 \\
\hline On-site, shallow zone & $20 / 20$ & 40 & 405 & 630 \\
\hline \multicolumn{5}{|l|}{ Molybdenum } \\
\hline Background & $2 / 6$ & $<0.01$ & $<0.01$ & 0.03 \\
\hline On-site & $3 / 6$ & $<0.01$ & $<0.02$ & 0.03 \\
\hline Off-site & $5 / 10$ & $<0.01$ & $<0.01$ & 0.03 \\
\hline On-site, shallow zone & $8 / 8$ & 0.36 & 0.57 & 0.68 \\
\hline \multicolumn{5}{|l|}{ Nitrate } \\
\hline Background & $4 / 6$ & $<0.1$ & $<1.0$ & 4.0 \\
\hline On-site & $4 / 6$ & $<0.1$ & $<1.2$ & 3.2 \\
\hline Off-site & $4 / 10$ & $<0.1$ & $<1.0$ & 3.5 \\
\hline On-site, shallow zone & $7 / 7$ & 66 & 96 & 130 \\
\hline \multicolumn{5}{|l|}{ Phosphate } \\
\hline Background & $4 / 4$ & 0.6 & 0.7 & 0.8 \\
\hline On-site & $4 / 4$ & 0.7 & 0.8 & 1.3 \\
\hline Off-site & $8 / 8$ & 0.2 & 0.5 & 1.0 \\
\hline On-site, shallow zone & $10 / 13$ & $<0.1$ & 0.2 & 0.9 \\
\hline \multicolumn{5}{|l|}{ Potassium } \\
\hline Upgradient & $6 / 6$ & 0.4 & 1.5 & 1.8 \\
\hline On-site & $6 / 6$ & 4.3 & 5.6 & 10.1 \\
\hline Off-site & $10 / 10$ & 1.4 & 2.3 & 6.2 \\
\hline On-site, shallow zone & $20 / 20$ & 14 & 35 & 52 \\
\hline \multicolumn{5}{|l|}{ Radium-226 $6^{e}$} \\
\hline Upgradient & 4 & 0.0 & 0.1 & 0.2 \\
\hline On-site & 4 & 0.0 & 0.1 & 0.2 \\
\hline Off-site & 4 & 0.0 & 0.1 & 1.3 \\
\hline On-site, shallow zone & 9 & 1.3 & 2.4 & 4.3 \\
\hline
\end{tabular}


Table 3.3 Summary of filtered water quality in the lower zone near Bowman, North Dakota (1986-1990) (Continued)

\begin{tabular}{|c|c|c|c|c|}
\hline \multirow[b]{2}{*}{ Parameter ${ }^{b}$} & \multirow[b]{2}{*}{$\begin{array}{l}\text { Frequency of } \\
\text { detectionc }\end{array}$} & \multicolumn{3}{|c|}{ Observed concentrations } \\
\hline & & $\begin{array}{c}\text { Minimum } \\
(\mathrm{mg} / \mathrm{L})\end{array}$ & $\begin{array}{c}\text { Median }^{a} \\
\text { (mg/L) }\end{array}$ & $\begin{array}{c}\text { Maximum } \\
\text { (mg/L) }\end{array}$ \\
\hline \multicolumn{5}{|l|}{ Selenium } \\
\hline Upgradient & $1 / 6$ & $<0.001$ & $<0.005$ & 0.006 \\
\hline On-site & $2 / 6$ & $<0.001$ & $<0.005$ & 0.014 \\
\hline Off-site & $2 / 10$ & $<0.001$ & $<0.005$ & 0.010 \\
\hline On-site, shallow zone & $17 / 20$ & $<0.005$ & 0.069 & 0.18 \\
\hline \multicolumn{5}{|l|}{ Silver } \\
\hline Upgradient & $0 / 6$ & $<0.01$ & $<0.01$ & $<0.01$ \\
\hline On-site & $1 / 6$ & $<0.01$ & $<0.01$ & 0.01 \\
\hline Off-site & $0 / 10$ & $<0.01$ & $<0.01$ & $<0.01$ \\
\hline On-site, shallow zone & $8 / 19$ & $<0.01$ & $<0.01$ & 0.03 \\
\hline \multicolumn{5}{|l|}{ Sodium } \\
\hline Upgradient & $6 / 6$ & 375 & 415 & 434 \\
\hline On-site & $6 / 6$ & 629 & 648 & 680 \\
\hline Off-site & $10 / 10$ & 525 & 543 & 600 \\
\hline On-site, shallow zone & $20 / 20$ & 443 & 915 & 1740 \\
\hline \multicolumn{5}{|l|}{ Strontium } \\
\hline Upgradient & $3 / 6$ & $<0.01$ & $<0.05$ & 0.07 \\
\hline On-site & $5 / 6$ & 0.06 & 0.12 & 1.25 \\
\hline Off-site & $7 / 10$ & 0.05 & $<0.10$ & 0.11 \\
\hline On-site, shallow zone & $19 / 19$ & 1.2 & 3.0 & 4.6 \\
\hline \multicolumn{5}{|l|}{ Sulfate } \\
\hline Upgradient & $6 / 6$ & 337 & 378 & 400 \\
\hline On-site & $6 / 6$ & 710 & 819 & 850 \\
\hline Off-site & $10 / 10$ & 585 & 633 & 660 \\
\hline On-site, shallow zone & $20 / 20$ & 1420 & 3195 & 6200 \\
\hline \multicolumn{5}{|l|}{ Uranium } \\
\hline Upgradient & $2 / 6$ & $<0.0003$ & $<0.0007$ & 0.0008 \\
\hline On-site & $2 / 6$ & $<0.0003$ & $<0.0011$ & 0.0014 \\
\hline Off-site & $7 / 10$ & 0.0004 & $<0.0030$ & 0.0036 \\
\hline On-site, shallow zone & $14 / 14$ & 0.25 & 0.31 & 0.39 \\
\hline
\end{tabular}


Table 3.3 Summary of filtered water quality in the lower zone near Bowman, North Dakota (1986-1990) (Concluded)

\begin{tabular}{|c|c|c|c|c|}
\hline \multirow[b]{2}{*}{ Parameter $^{\mathbf{b}}$} & \multirow[b]{2}{*}{$\begin{array}{c}\text { Frequency of } \\
\text { detectionc }\end{array}$} & \multicolumn{3}{|c|}{ Observed concentrations } \\
\hline & & $\begin{array}{l}\text { Minimum } \\
\text { (mg/L) }\end{array}$ & $\begin{array}{c}\text { Median }^{a} \\
\text { (mg/L) }\end{array}$ & $\begin{array}{c}\text { Maximum } \\
(\mathrm{mg} / \mathrm{L})\end{array}$ \\
\hline \multicolumn{5}{|l|}{ Vanadium } \\
\hline Upgradient & $1 / 6$ & $<0.01$ & $<0.01$ & 0.01 \\
\hline On-site & $1 / 6$ & $<0.01$ & $<0.01$ & 0.02 \\
\hline Off-site & $0 / 10$ & $<0.01$ & $<0.01$ & $<0.01$ \\
\hline On-site, shallow zone & $16 / 20$ & $<0.01$ & 0.05 & 0.40 \\
\hline \multicolumn{5}{|l|}{ Zinc } \\
\hline Upgradient & $3 / 6$ & $<0.005$ & $<0.006$ & 0.033 \\
\hline On-site & $1 / 6$ & $<0.005$ & $<0.005$ & 0.031 \\
\hline Off-site & $3 / 10$ & 0.004 & $<0.005$ & 0.018 \\
\hline On-site, shallow zone & $14 / 19$ & $<0.005$ & 0.017 & 0.073 \\
\hline
\end{tabular}

${ }^{\mathrm{a}}$ The 50 th percentile of the data.

b Background data are from DOE monitor well 511. On-site data are from DOE monitor well 512. Off-site data are from DOE monitor wells 513,521, and 522. On-site (shallow zone) data from Table 3.2 are included for comparison.

CNumber of water samples with detectable concentrations/total number of samples.

dDue to several rounds with high laboratory detection limits, the median of the data cannot be estimated with any degree of precision.

${ }^{e}$ Radium-226 concentrations are in picocuries per liter. Frequency of detection is not applicable for radionuclide measurements. Number of samples is presented.

Note: Table summarizes the available water quality data for the lower zone for those constituents identified as above background in the shallow zone (Table 3.4, column 1). 
site as a plume but remains concentrated in a distinct region beneath and adjacent to the site (DOE, 1990).

\subsection{CONTAMINANTS OF POTENTIAL CONCERN}

Based on the results presented in Sections 3.1 and 3.2, it was determined that shallow ground water contains the greatest concentrations of potential siterelated contaminants. Therefore, shallow ground water quality is evaluated in this risk assessment to predict the greatest potential for adverse health impacts from exposure to contaminated ground water in the site vicinity. Risks associated with contaminant levels in the lower zone would be expected to be less than those presented for the shallow ground water because at the lower concentration levels, risk is directly proportional to concentration. Therefore, exposures and risk from specific contaminants would be less for the lower zone.

A list of contaminants of potential concern for the assessment of human health risks from exposure to contaminated ground water at this site is compiled from an analysis of water quality in the shallow ground water system. A statistical analysis of water quality data from on-site monitor wells 502, 503, and 517 and background monitor wells 518 and 519 compiled an initial list of constituents that were higher in on-site wells than in background wells. This comparison used only data from the four sampling dates common to the five wells. This was to account for the significant date-to-date variability in the data. A randomized block model was assumed, viewing sampling dates as a random factor. An analysis of variance test of the location effect, comparing on-site to background, was conducted at the 0.05 level of significance. Constituents statistically elevated above background levels are arsenic, boron, calcium, chloride, fluoride, magnesium, molybdenum, nitrate, phosphate, potassium, selenium, silver, sodium, strontium, sulfate, uranium, and zinc.

In addition to the randomized block test, a second review was conducted of the data for constituents statistically determined to be at or below background. Data for sampling dates excluded from the blocked analysis were examined. This secondary data review resulted in the addition of radium-226 and vanadium to the list of constituents that are above background levels. Radium-226 was added to the list of constituents above background levels because higher concentrations were observed in off-site wells 530, 531, and 532 and vanadium was added because it is expected in association with lignite ash and although off-site concentrations are not statistically above background vanadium is evident in off-site wells around the site. Limited analyses for bromide prevented a statistical comparison of on-site conditions to background. Bromide is not expected in relation to the lignite ashing process and would not be at or above levels of toxity. Therefore, bromide was eliminated from further evaluation. This screening provides an estimate of the types of contamination in shallow ground water beneath the site potentially resulting from processing activities. Table 3.4, column 1, lists the constituents in ground water that are higher on the site than in background wells, based on the methodology described above. 
Table 3.4 Summary of contaminants of potential concern for human health in the shallow ground water system, Bowman, North Dakota, site

\begin{tabular}{|c|c|c|c|}
\hline $\begin{array}{c}\text { Contaminants above } \\
\text { background levels }\end{array}$ & $\begin{array}{c}\text { Contaminants } \\
\text { within nutritional } \\
\text { range }\end{array}$ & $\begin{array}{l}\text { Contaminants } \\
\text { with low toxicity } \\
\text { and/or high } \\
\text { dietary range }\end{array}$ & $\begin{array}{l}\text { Contaminants } \\
\text { of potential } \\
\text { concern }\end{array}$ \\
\hline $\begin{array}{l}\text { Arsenic } \\
\text { Boron } \\
\text { Calcium } \\
\text { Chloride } \\
\text { Fluoride } \\
\text { Magnesium } \\
\text { Molybdenum } \\
\text { Nitrate } \\
\text { Phosphate } \\
\text { Potassium } \\
\text { Radium-226 } \\
\text { Selenium } \\
\text { Silver } \\
\text { Sodium } \\
\text { Strontium } \\
\text { Sulfate } \\
\text { Uranium } \\
\text { Vanadium } \\
\text { Zinc }\end{array}$ & $\begin{array}{l}\text { Calcium } \\
\text { Chloride } \\
\text { Fluoride } \\
\text { Potassium } \\
\text { Zinc }\end{array}$ & $\begin{array}{l}\text { Boron } \\
\text { Magnesium } \\
\text { Phosphate } \\
\text { Silver } \\
\text { Strontium }\end{array}$ & $\begin{array}{l}\text { Arsenic } \\
\text { Molybdenum } \\
\text { Nitrate }^{\mathrm{e}} \\
\text { Radium-226 } \\
\text { Selenium } \\
\text { Sodium } \\
\text { Sulfate } \\
\text { Uranium } \\
\text { Vanadium }\end{array}$ \\
\hline
\end{tabular}

aLevels are below health advisory criteria (oral RfD, no observable effect level).

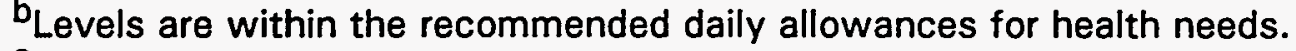

Levels are below common dietary intake levels.

dDerived by removing column 2 and column 3 constituents from column 1 .

$\boldsymbol{e}_{\text {Not }}$ attributed to the processing site. 
Data from filtered water samples were used in this evaluation. Potential receptors to this ground water, however, would be exposed to unfiltered water. In 1993, both filtered and unfiltered water samples were collected and analyzed for a full suite of inorganic parameters. The one round of unfiltered data could not characterize water quality at the site. However, data pairs of filtered and unfiltered results were compared to assess the impact that filtering may have had on the constituent concentrations in monitor well samples.

Of the constituents identified as being above background, filtered and unfiltered 1993 data pairs are available for arsenic, calcium, magnesium, molybdenum, potassium, radium-226, selenium, sodium, uranium and vanadium. Based on data from five wells with detectable selenium, the unfiltered results averaged 60 percent higher than filtered results. On average, unfiltered radium-226 and uranium concentrations were less than 5 percent greater than the concentrations measured in filtered samples. The other constituents showed no consistent differences between filtered and unfiltered results. The higher unfiltered levels of radium-226, selenium, and uranium are considered when evaluating the potential risks associated with exposure to these constituents in Section 6.0. The effects of a 60-percent increase in selenium exposures are examined in the assessment of potential health impacts. Increases of less than 5 percent in concentrations of radium-226 or uranium are considered insignificant in the evaluation of carcinogenic and noncarcinogenic risks from radionuclidds.

A list of potentially site-related constituents was evaluated for toxicity to human health using the health-based criteria discussed below. Several constituents, although present above background, were eliminated because their concentrations are within acceptable nutritional ranges (at low toxicity levels) or are within the expected dietary range. The criteria for acceptable nutritional range are based on the National Research Council, recommended dietary allowance (RDA) (National Research Council, 1989). The criteria for expected dietary range are based on the Agency for Toxic Substances and Disease Registry, the EPA Integrated Risk Information System (IRIS) (EPA, 1994a), and the Handbook on the Toxicology of Metals (Friberg et al., 1986). These publications identify common intake rates for specific nutrients. A constituent was considered to have low toxicity when the anticipated exposure dose fell well below any known adverse health effect level in the literature. Constituent toxicity evaluations at this screening level used the 95 percent upper confidence limit of mean concentrations in ground water to estimate a potential average daily dose. The result was compared to available values known to cause adverse health effects. Arsenic, molybdenum, radium-226, selenium, sodium, sulfate, vanadium, and uranium remained as the contaminants of potential concern for human health in the shallow ground water system at the Bowman site (Table 3.4). More comprehensive toxicological evaluations, summarized in the toxicity profiles in Section 5.0, were compiled for the final list of sitespecific contaminants of potential concern. 
Based on the geochemical analysis of water quality presented in Section 3.2, several constituents detected in ground water in on- and off-site monitor wells are not attributable to the ashing process. Nitrate, phosphate, and chloride are not expected from raw lignite or lignite ash, and are considered unrelated to site activities. There is also little evidence that boron, fluoride, and bromide would be expected from site activities. Furthermore, elevated levels of the major cations and anions (sodium, sulfate, magnesium, calcium, and potassium) are not conclusively the result of lignite burning. The statistical data analysis identified these constituents as above background levels in on-site monitor wells, thus putting them on the initial list of potential site-related contaminants. Chloride, boron, fluoride, magnesium, calcium, potassium, and phosphate were screened from the list of contaminants of potential concern through the evaluation of their toxicity observed levels. Potential risks associated with sodium and sulfate concentrations in ground water were fully evaluated in this risk assessment. However, potential risks from exposure to nitrate in ground water is clearly unrelated to site-activities and therefore, was not evaluated further. The potential for nitrate interactions with site contaminants and the impact on the overall risks is addressed in Section 5.0.

Radium-226, radionuclides associated with natural uranium, (Section 5.1.6) is the only radionuclide that was quantitatively above background. Therefore, it is included on the list of contaminants of potential concern. However, data for each of the radioactive uranium progeny are incorporated into the calculation of lifetime cancer risk (Section 6.2). Effects from radioactivity are additive; therefore, even naturally occurring concentrations contribute to the total cancer risk. Furthermore, because uranium is attributed to the ashing process, its radioactive progeny may be considered a site-related health risk.

Background water quality has concentrations of selenium, molybdenum, antimony, cadmium, and lead above health advisories and/or EPA maximum concentration limits (MCL) (Section 8.3). Although many of the maximum concentrations detected of these trace elements represent only one sampling round and levels are lower in current samples, these conditions suggest the potential for risk from chronic ingestion of background ground water. Siterelated risks identified for the contaminants of potential concern are incremental to any risk associated with natural background levels of trace elements. The potential risk from ingesting background ground water in the site vicinity is not evaluated individually in this risk assessment. Section 8.3 compares background water quality to the available health-based criteria and/or EPA MCLS in relation to overall site conditions.

\subsection{CONTAMINANT FATE AND TRANSPORT}

Contaminant movement through an aquifer is governed by advective transport of ground water, precipitation and dissolution reactions, and the interaction between solute and solid phases of the aquifer matrix (sorption processes). The likely behavior of contaminants in ground water beneath and adjacent to the Bowman site is discussed below. 
Hydrodynamic dispersion is responsible for the dilution of contaminants in ground water. The greater the distance ground water travels the greater the dispersion and dilution effects, through mixing along the flow path.

The chemical speciation of an element in ground water is determined by the chemical composition of ground water, including $\mathrm{pH}$, redox potential, temperature, the availability of ions and complexes, and concentration. Chemical speciation greatly influences constituent mobility in ground water. Concentration plus speciation affects the toxicokinetics and toxicity of an element present in ground water.

Thermodynamic modeling using the geochemical computer code MINTEQA2 (Allison et al., 1991) was performed using water quality data from DOE monitor well 517 and the maximum on-site concentrations of the contaminants of potential concern. The oxidation states, aqueous speciations, and the state of saturation of mineral phases for the contaminants of potential concern were generated (Table 3.5). The potential attenuation or mobility of each contaminant of potential concern and information on the aquifer matrix materials and the hydrogeologic regime are used to predict the potential of contaminants to move off the site. The predicted fate and transport of each contaminant of potential concern is summarized below. This information is used to support decisions on the extent of off-site contamination.

\section{Arsenic}

Low arsenic concentrations are present in shallow ground water beneath the site as an arsenate oxyanion. Arsenic is moderately mobile in an oxidizing aqueous environment as an arsenate species, generally, the mobility increases as the oxidation state of arsenic decreases from the (V) to (III) (i.e., arsenic [III] species generally sorb onto the aquifer matrix less readily than As[V] species) (Rai and Zachara, 1984). At concentrations found in ground water at the Bowman site (maximum of $0.018 \mathrm{mg} / \mathrm{L}$ ), the main factor influencing arsenic mobility is likely adsorption onto the aquifer matrix, particularly ferric oxyhydroxides and lignite, thus removing arsenic from the ground water. The fact that arsenic concentrations are less than the analytical detection limit in ground water downgradient from the site provides evidence that arsenic is not migrating away from the site. Hydrodynamic dispersion is also responsible for reducing concentrations of arsenic downgradient from the site.

\section{Molybdenum}

Molybdenium is associated with uranium lignite and was mobilized during the burning process. Molybdenum present in ground water in the site vicinity is predominantly the Mo(VI) molybdate species. Molybdate is relatively mobile under moderately oxidizing conditions at a $\mathrm{pH}$ above 8 but is removed from ground water by sorption onto ferric oxyhydroxides (Rai and Zachara, 1984; Leckie et al., 1980) and perhaps onto lignite humic material below a $\mathrm{pH}$ of approximately 6 . The $\mathrm{pH}$ measured in monitor wells 530,531, and 532, 
Table 3.5 Geochemical analysis of the contaminants of potential concern in shallow ground water at the Bowman, North Dakota, site

\begin{tabular}{|c|c|c|c|c|}
\hline Contaminant & Chemical name & $\begin{array}{c}\text { Oxidation } \\
\text { state }\end{array}$ & Speciation & $\begin{array}{c}\text { Molar } \\
\text { percent }\end{array}$ \\
\hline \multirow[t]{2}{*}{ Arsenic } & Arsenate & V & $\mathrm{HAsO}_{4}{ }^{2-}$ & 62 \\
\hline & Arsenate & V & $\mathrm{H}_{2} \mathrm{AsO}_{4}^{-}$ & 38 \\
\hline Molybdenum ${ }^{a}$ & Molybdate & VI & $\mathrm{MoO}_{4}{ }^{2-}$ & 100 \\
\hline Radium ${ }^{a}$ & Radium-226 & II & $\mathrm{Ra}^{2+}$ & 100 \\
\hline \multirow[t]{2}{*}{ Selenium } & Selenite & IV & $\mathrm{HSeO}_{3}^{-}$ & 97 \\
\hline & & IV & $\mathrm{SeO}_{3}^{2-}$ & 3 \\
\hline \multirow[t]{4}{*}{ Sulfur } & Sulfate & VI & $\mathrm{SO}_{4}^{2-}$ & 78 \\
\hline & Magnesium sulfate & VI & $\mathrm{MgSO}_{4 \mathrm{AO}}$ & 13 \\
\hline & Calcium sulfate & VI & $\mathrm{CaSO}_{4 \mathrm{AO}}$ & 6 \\
\hline & Sodium sulfate & VI & $\mathrm{NaSO}_{4}^{-}$ & 3 \\
\hline \multirow[t]{3}{*}{ Uranium } & Uranyl tricarbonate & VI & $\mathrm{UO}_{2}\left(\mathrm{CO}_{3}\right)_{3}^{4-}$ & 58 \\
\hline & Uranyl dicarbonate & VI & $\mathrm{UO}_{2}\left(\mathrm{CO}_{3}\right)^{2-}$ & 39 \\
\hline & Uranyl carbonate & VI & $\mathrm{UO}_{2}\left(\mathrm{CO}_{3}\right)_{A O}$ & 3 \\
\hline \multirow[t]{4}{*}{ Vanadium } & Pyrovanadate & V & $\mathrm{HV}_{2} \mathrm{O}_{7}^{-3}$ & 80 \\
\hline & Orthovanadate & V & $\mathrm{H}_{2} \mathrm{VO}_{4}^{-}$ & 17 \\
\hline & Pyrovanadate & V & $\mathrm{H}_{3} \mathrm{~V}_{2} \mathrm{O}_{7}^{-}$ & 2 \\
\hline & Orthovanadate & V & $\mathrm{HVO}_{4}{ }^{2-}$ & 1 \\
\hline
\end{tabular}

\footnotetext{
${ }^{a}$ Species and oxidation state determined from Brookins (1988).
} 
downgradient from the site, ranges from 6.1 to 6.9 . Therefore, under these conditions at the Bowman site, some removal of molybdenum from ground water is likely occurring as ground water moves down the flow path. Hydrodynamic dispersion also affects molybdenum dilution, explaining the distinct drop in molybdenum concentrations downgradient of the site.

\section{Selenium}

Selenium is associated with uranium in lignite and was mobilized during the burning process. Selenium as selenite, Se(IV), is the predominant species in contaminated ground water on the site. Analysis of ground water downgradient from the site (in monitor wells 529,530,531, and 532) shows selenium concentrations at or slightly above the analytical detection limit, much lower than the on-site maximum of $0.18 \mathrm{mg} / \mathrm{L}$. This suggests that in addition to hydrodynamic dispersion, selenium adsorption by aquifer materials such as lignite (Karner et al., 1986) and ferric oxyhydroxides (Leckie et al., 1980), occurs down the flow path.

\section{Sulfate}

Elevated sulfate concentrations in ground water in the site vicinity are caused by oxidation of reduced sulfur (sulfide minerals and native sulfur) during the lignite burning process. Sulfate is present in ground water predominantly as a $\mathrm{SO}_{4}{ }^{2-}$ ion or as calcium, magnesium, or sodium complexes. No sulfate mineral phases are saturated with respect to ground water. Therefore, precipitation of sulfate minerals is unlikely. Although sulfate is variable in ground water on and off the site, a decrease in concentration is apparent down the flow path. Hydrodynamic dispersion and the chemical heterogeneity of the aquifer matrix and ground water in the area could cause these charges in sulfate concentrations.

\section{Sodium}

The liberation of sodium from burning lignite (Fulton, 1989) and cation exchange with calcium and magnesium in clays are responsible for the elevated sodium concentration in contaminated ground water. Sodium is present in ground water predominately as a cation, $\mathrm{Na}(\mathrm{l})$. Ground water is not oversaturated with respect to any minerals phases; therefore, sodium removal is not expected by precipitation. The primary mechanism of sodium attenuation is most likely cation exchange with clay minerals but sodium acts as a somewhat conservative cation if calcium or other divalent alkali earth elements are present in elevated concentrations within the system. Therefore, if divalent cations saturate clay exchange sites, sodium is expected to persist in ground water downgradient from the former mill site. 


\section{Uranium}

Uranium is present above background levels on-site in DOE monitor wells 517 , 502, and 503, as an effect of the ashing process. Under moderately oxidizing conditions, uranium exists as uranyl carbonate complexes. No uranium mineral phases are thermodynamically saturated with respect to ground water in the contaminated region of the aquifer so the removal of uranium from precipitation reactions is not expected. Sorption of uranium onto the aquifer matrix such as in the formation of iron oxyhydroxides (Kent et al., 1988; Hsi and Langmuir, 1985 ) and lignite/humic material is a possible mechanism that would reduce levels of uranium away from the site (Nakashima, 1992; Mohan et al., 1991). Hydrodynamic dispersion is also expected to dilute uranium in ground water down the flow path. Uranium resulting from the ashing process is not distinguishable off the site. Variable concentrations are likely due to these processes and the natural occurrence of uranium throughout the region resulting from the geologic formations in the area.

\section{Vanadium}

On-site vanadium contamination in ground water is a result of the lignite ashing process. Field redox and $\mathrm{pH}$ data suggest vanadium is present as $\mathrm{V}(\mathrm{V})$ oxyanion complexes in ground water beneath the site. No mineral phases are oversaturated in ground water beneath the site; therefore precipitation reactions are not expected. Sorption onto aquifer materials such as chemically active lignite stringers (Miller and Given, 1986) is probably responsible for attenuation of vanadium down the ground water flow path. Low vanadium concentrations in downgradient monitor wells 530,531 , and 532 support this assumption.

\section{Radium-226}

Radium-226 is present above background levels in on-site monitor wells, existing predominantly as the $\mathrm{Ra}^{2+}$ cation (Brookins, 1988). However, radium226 concentrations downgradient from the site in DOE monitor wells 530,531 , and 532 exceed $12 \mathrm{pCi} / \mathrm{L}$ for radium-226 plus radium-228. This is approximately four times greater than the maximum on-site ground water value. Radium-226 at these locations is not considered site-related. It likely represents a solute-concentrated zone at the top of the water table where all three wells are screened. Radium-226 appears to be naturally concentrated in this region and may be related to the natural uranium values in ground water that are above background in this region of the site vicinity.

\subsection{SURFACE WATER QUALITY}

There are no perennial streams or surface expressions of ground water near the site, except for occasional ponding of accumulated precipitation. Many of the surface water locations sampled in the past were seasonal and could not be sampled more than once. Because both the occurrence of surface water and the available surface water quality data are inconsistent, changes in surface 
water quality potentially due to the processing site are not measurable.

Sampling locations further from the site consisted of locations along the ephemeral Spring Creek and a wetland area along U.S. Highway 12, $0.75 \mathrm{mi}$ $(1.2 \mathrm{~m})$ west of the site. Data are limited for these locations.

In summary, surface water sampling locations are sporadic, and often exist only as a result of precipitation events. Furthermore, ground water does not express itself aboveground. Therefore, contamination is not potentially available to receptors through surface water. Surface water quality data were not used to evaluate risk either to humans or biota. 


\subsection{EXPOSURE ASSESSMENT}

This section discusses and quantifies the potential exposures that could be incurred by current or future residents who may use ground water or surface water in the vicinity of the Bowman UMTRA Project site. The methodology used here is consistent with the latest EPA guidance on exposure assessments (EPA, 1989a), which recommends an analysis based on the reasonable maximum exposure under both current and future land-use conditions. The reasonable maximum exposure is defined as the highest exposure that can be reasonably expected to occur at the site.

\subsection{POTENTIALLY EXPOSED POPULATION}

Exposure can occur only when there are both a source of contamination and a mechanism of transport to a receptor population or individual. Ground water is the only water source for residences in the area of the Bowman UMTRA Project site. Ground water from the deep sandstone aquifers in the region are the most common source of drinking water. The municipal water supply system for the town of Bowman obtains ground water from three wells south of town, each more than $1000 \mathrm{ft}(300 \mathrm{~m})$ deep and penetrating the deep sandstone aquifer. The site itself is $7 \mathrm{mi}(11 \mathrm{~km})$ west of town and residents in the site area do not have access to the municipal water supply. Although contamination attributable to the ashing process is in an area beneath and adjacent to the site, the domestic wells monitored in the site area are not impacted. The one residence adjacent to the site uses two wells (one deep and one shallow) for domestic purposes. Although contamination is not detected in these wells and water is not used for drinking (the residents drinking bottled water), ground water contamination could impact these wells and the contaminated ground water could be used for drinking. The potential future exposures from these wells, based on exposure estimates for current water quality directly beneath the site, will likely be overestimated. Any potential future contamination reaching these wells would clearly be less than current on-site conditions.

In summary, there is no current receptor population or individual. However, a future ground water use scenario for contaminated ground water originating from the former lignite ashing site is assumed for this risk assessment.

Domestic ground water use is assumed to be consistent with current use by the rural population in southwestern North Dakota and exposure is based on the highest constituent levels observed at the site. The potentially exposed population includes individuals in the following age groups: infants (birth to 1 year), children ( 1 to 10 years), and adults (11 to 64 years). These age groups were selected for the following reasons:

- Survey data for population variables such as age, weight, and daily water intake are available for these age groups.

- Toxicological variables are similar within these age groups, including responsiveness of sensitive subgroups (infants and children) to the 
contaminants of potential concern, toxicant intake to body weight ratios, and toxicokinetics.

\subsection{EXPOSURE PATHWAYS}

Evaluating potential exposure pathways involves determining the most likely pathways and the major contributing pathways to risk as a function of potential exposure dose. Given the chemical properties of the contaminants of potential concern at UMTRA Project sites, drinking water ingestion is expected to be the most significant exposure pathway for ground water contaminated with metals and other nonvolatile compounds. In this evaluation, drinking water consumption includes water consumed by drinking and water in food preparation (e.g., reconstituted juices, soup, rice, and beans). A screening assessment compared other possible exposure pathways to the ingestion pathway to identify the potential dose contribution from these other pathways. The potential impacts from these additional dose contributions to the overall risk evaluation for the site are discussed in Section 6.0.

Other potential pathways that could directly or indirectly lead to human exposure include dermal contact, ingestion of garden produce irrigated with contaminated ground water, and ingestion of meat or milk from livestock watered with contaminated ground water for the Bowman site. Figure 4.1 provides a conceptual model for potential exposure pathways to shallow ground water. All the exposure pathways evaluated here represent future potential pathways because currently there are no complete pathways to contaminated ground water.

\subsubsection{Drinking water ingestion}

Comparing the relative significance of each pathway to the drinking water pathway focuses this risk assessment on the greatest potential intake.

Screening calculations used the 95 percent upper confidence limit for the mean concentration of a contaminant accessed by the most contaminated on-site wells. Maximum concentrations were used for radionuclides because the dataset is limited. Screening calculations are based on adult exposure for chronic residence time (greater than 7 years). Drinking water intakes are then compared to the intakes from other potential exposure pathways (Table 4.1).

\subsubsection{Dermal absorption}

Dermal absorption is the process by which chemicals coming into contact with the skin are absorbed into the blood vessels near the surface of the skin. Some compounds are absorbed easily in this manner, although metals do not possess the chemical properties that are conducive to skin absorption. Because chemical-specific absorption factors are not available for these contaminants, they are assumed to absorb across the skin at the same rate as water. This assumption probably will overestimate any potential contribution from dermal absorption. The concentration in water was assumed to be the 95 percent 


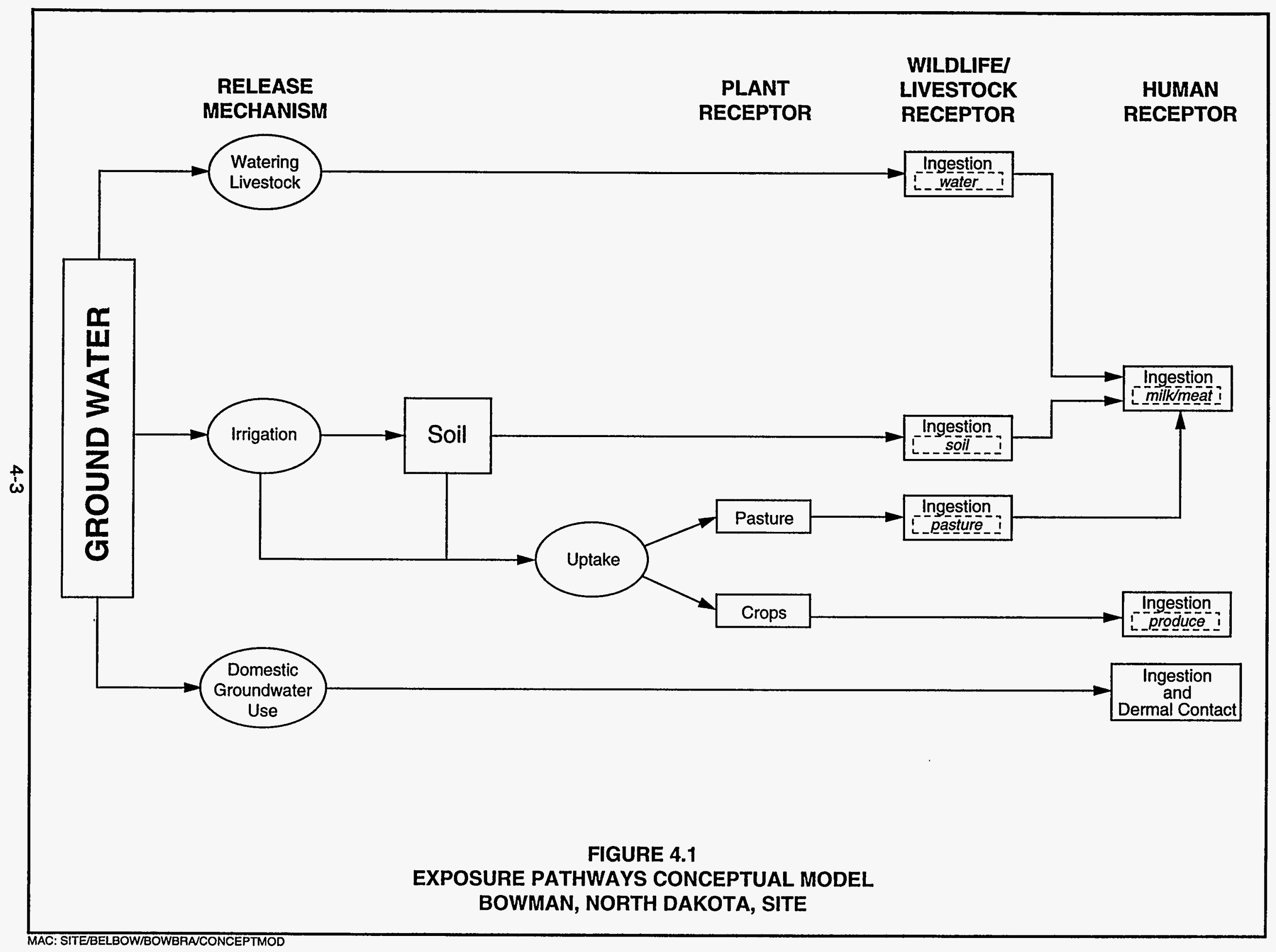


Table 4.1 Exposure dose calculations for ground water ingestion and dermal contact, Bowman, North Dakota, site

\begin{tabular}{|c|c|c|c|c|}
\hline \multirow{2}{*}{$\begin{array}{c}\text { Contaminant of potential } \\
\text { concern }\end{array}$} & \multirow[b]{2}{*}{ Cw } & \multicolumn{2}{|c|}{$\begin{array}{l}\text { Ground water exposure dose } \\
\text { (mg/kg-day) }\end{array}$} & \multirow{2}{*}{$\begin{array}{l}\text { Ratio of dermal } \\
\text { contact to } \\
\text { ingestion }\end{array}$} \\
\hline & & Ingestion & Dermal contact & \\
\hline \multicolumn{5}{|l|}{ Noncarcinogenic effects $(\mathrm{mg} / \mathrm{L})$} \\
\hline $\begin{array}{l}\text { Arsenic } \\
\text { Molybdenum } \\
\text { Selenium } \\
\text { Sodium } \\
\text { Sulfate } \\
\text { Uranium } \\
\text { Vanadium }\end{array}$ & $\begin{array}{c}0.007 \\
0.64 \\
0.12 \\
1551 \\
5780 \\
0.33 \\
0.15\end{array}$ & $\begin{array}{r}2 E-04 \\
2 E-02 \\
3 E-03 \\
4 E+01 \\
2 E+02 \\
9 E-03 \\
4 E-03\end{array}$ & $\begin{array}{l}4 \mathrm{E}-07 \\
3 \mathrm{E}-05 \\
6 \mathrm{E}-06 \\
8 \mathrm{E}-02 \\
3 \mathrm{E}-01 \\
2 \mathrm{E}-05 \\
8 \mathrm{E}-06\end{array}$ & $\begin{array}{l}0.002 \\
0.002 \\
0.002 \\
0.002 \\
0.002 \\
0.002 \\
0.002\end{array}$ \\
\hline \multicolumn{5}{|l|}{ Carcinogenic effects (pCi/L) } \\
\hline $\begin{array}{l}\text { Arsenic (mg/L) } \\
\text { Radium-226 } \\
\text { Uranium }^{\mathrm{C}}\end{array}$ & $\begin{array}{l}0.007 \\
3.0 \\
266\end{array}$ & $\begin{array}{r}1 E-04 \\
2 E+05^{b} \\
1 E+07^{b}\end{array}$ & $\begin{array}{r}3 E-07 \\
3 E+02^{b} \\
2 E+04^{b}\end{array}$ & $\begin{array}{l}0.002 \\
0.002 \\
0.002\end{array}$ \\
\hline
\end{tabular}

Equation definitions for exposure dose calculations

Ingestion of ground water

Chemicals

Chronic daily intake $\left(\mathrm{mg} / \mathrm{kg}\right.$-day) $=\frac{\mathrm{CW}_{W} \times \mathrm{IRw} \times \mathrm{EF} \times \mathrm{ED}}{\mathrm{BW} \times \mathrm{AT}}$

Radionuclides

Lifetime intake ( $\mathrm{pCi} /$ lifetime) $=\mathrm{CW} \times \mathrm{IRw} \times \mathrm{EF} \times \mathrm{ED}$

Dermal contact with ground water

Chemicals

Chronic daily intake $(\mathrm{mg} / \mathrm{kg}-$ day $)=(\mathrm{Cw} \times \mathrm{SA} \times \mathrm{PC} \times \mathrm{Cf}) \times \mathrm{ET} \times \mathrm{EF} \times \mathrm{ED}$ BW $\times$ AT

Radionuclides

Lifetime intake $(\mathrm{pCi} /$ lifetime $)=\mathrm{Cw} \times \mathrm{SA} \times \mathrm{PC} \times \mathrm{Cf} \times \mathrm{ET} \times \mathrm{EF} \times \mathrm{ED}$ 
Table 4.1 Exposure dose calculations for ground water ingestion and dermal contact, Bowman, North Dakota, site (Concluded)

Where:

$\mathrm{Cw}=$ Contaminant concentration in ground water 195 percent upper confidence limit for the mean) (milligrams per liter or picocuries per liter).

IRW = Ingestion rate for water ( $L$ per day) ( $2 \mathrm{~L}$ per day for an adult).

$\mathrm{EF}=$ Exposure frequency ( 350 days per year).

$E D=$ Exposure duration ( 50 years for an adult).

$B W=$ Body weight $(70 \mathrm{~kg}$ for an adult).

AT = Averaging time ( 365 days $\times$ ED for noncarcinogens, 365 days $\times 70$ years for carcinogens).

$S A=$ Skin surface area $(19,400$ square centimeters $)$.

Pc $=$ Dermal permeability constant $(0.001 \mathrm{~cm}$ per hour $)$.

Cf $=$ Conversion factor $\left(0.001 \mathrm{~L} / \mathrm{cm}^{3}\right)$.

ET = Exposure time (0.2 hour per day).

${ }^{a}$ Calculated by dividing the dermal contact exposure dose by the groundwater ingestion exposure dose.

${ }^{\text {b}}$ Picocuries per lifetime.

CUranium-234 and uranium-238 combined. 
upper confidence limit for the mean concentration of a constituent from the most contaminated on-site wells.

Although the dermal dose is an absorbed dose and the ingested dose is a total dose of which only a percentage will be absorbed, the contribution from dermal absorption ( 0.2 percent) is much less than the ingestion pathway (Table 4.1).

\subsubsection{Ingestion of ground water-irrigated produce}

The ingestion of ground water-irrigated produce was also evaluated and its relative dose compared to the drinking water ingestion pathway (Table 4.2). Produce from this garden is assumed to be the only source of produce in the diet, which will likely overestimate the exposure potential from this route. The results of this screening show that for the contaminants of potential concern at the site, ingesting garden vegetables and fruit irrigated with contaminated ground water may impact the intake of molybdenum by up to 5 percent more than the total intake from drinking water alone. The potential increased risk from this added intake is addressed in Section 6.0.

\subsubsection{Ingestion of milk or meat from ground water-fed livestock}

The relative contribution from ingesting the milk of ground water-fed livestock varies for the contaminants of potential concern. Through this exposure route, intake of most contaminants would increase the intake from drinking water by less than 5 percent (Table 4.3). For molybdenum and sodium, this pathway could increase intake an additional 15 and 25 percent, respectively.

In addition to the drinking water pathway, ingesting meat from these animals would increase intakes of molybdenum, sodium, and sulfate by 15 percent (Table 4.4). Intake contributions from the remaining constituents would be less than 1 percent of the total exposure from drinking water. The potential increase in risk from these sources of molybdenum, sodium, and sulfate are discussed in Section 6.0.

\subsubsection{Summary}

Results of the screening show that the drinking water pathway contributes the largest dose, and thus, the greatest potential risk to the individual. Intake of most constituents would be increased by a relatively small amount from most other pathways. Molybdenum intake may be increased by ingesting garden produce irrigated with contaminated ground water. Molybdenum and sodium intakes may be increased by ingesting meat and milk from livestock fed with contaminated ground water. However, the effects of these increased intakes on the potential risk of adverse health effects are important and are discussed in Section 6.0. 
Table 4.2 Exposure dose calculations for ground water-irrigated garden produce ingestion, Bowman, North Dakota, site

\begin{tabular}{|c|c|c|c|c|c|c|}
\hline $\begin{array}{c}\text { Contaminant of } \\
\text { potential } \\
\text { concern }\end{array}$ & Cw & $\underset{(\mathbf{L} / \mathbf{k g})}{\mathbf{K d}}$ & Bv & $\mathrm{Br}$ & $\begin{array}{l}\text { Garden produce } \\
\text { ingestion } \\
\text { exposure dose } \\
\text { (mg/kg-day) }\end{array}$ & $\begin{array}{l}\text { Ratio of produce } \\
\text { ingestion to water } \\
\text { ingestion }\end{array}$ \\
\hline \multicolumn{7}{|c|}{ Noncarcinogenic effects (mg/L) } \\
\hline $\begin{array}{l}\text { Arsenic } \\
\text { Molybdenum } \\
\text { Selenium } \\
\text { Sodium } \\
\text { Sulfate } \\
\text { Uranium } \\
\text { Vanadium }\end{array}$ & $\begin{array}{c}0.007 \\
0.64 \\
0.12 \\
1551 \\
5780 \\
0.33 \\
0.15\end{array}$ & $\begin{array}{c}19.4 \\
120 \\
14.9 \\
0.2 \\
0 \\
50 \\
100\end{array}$ & $\begin{array}{l}0.04 \\
0.25 \\
0.025 \\
0.075 \\
0.5 \\
0.0085 \\
0.0055\end{array}$ & $\begin{array}{l}0.006 \\
0.06 \\
0.025 \\
0.055 \\
0.5 \\
0.004 \\
0.003\end{array}$ & $\begin{array}{r}3 E-07 \\
1 \mathrm{E}-03 \\
3 \mathrm{E}-06 \\
2 \mathrm{E}-03 \\
\mathrm{C} \\
8 \mathrm{E}-06 \\
5 \mathrm{E}-06\end{array}$ & $\begin{array}{l}0.002 \\
0.05 \\
0.001 \\
0.00005 \\
c \\
0.0009 \\
0.001\end{array}$ \\
\hline \multicolumn{7}{|c|}{ Carcinogenic effects (pCi/L) } \\
\hline $\begin{array}{l}\text { Arsenic }(\mathrm{mg} / \mathrm{L}) \\
\text { Radium-226 } \\
\text { Uranium }\end{array}$ & $\begin{array}{l}0.007 \\
3.0 \\
226\end{array}$ & $\begin{array}{l}19.4 \\
100 \\
50\end{array}$ & $\begin{array}{l}0.040 \\
0.015 \\
0.0085\end{array}$ & $\begin{array}{l}0.006 \\
0.0015 \\
0.004\end{array}$ & $\begin{array}{r}3 E-07 \\
4 E+02^{d} \\
1 E+04^{d}\end{array}$ & $\begin{array}{l}0.003 \\
0.002 \\
0.001\end{array}$ \\
\hline
\end{tabular}

Equation definitions for exposure dose calculations

Ingestion of garden produce irrigated with ground water

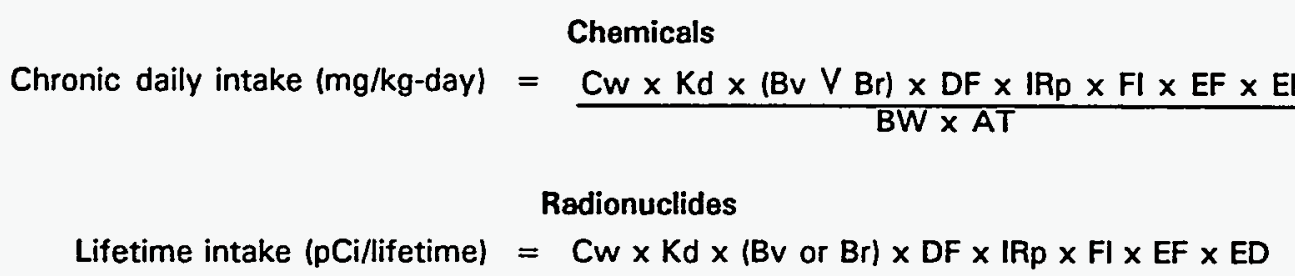

Where:

$\mathrm{Cw}=$ Contaminant concentration in ground water (95 percent upper confidence limit for the mean) (milligrams per liter or picocuries per liter).

Kd = Soil-water partition coefficient (liters per kilogram); from PNL (1989).

BV = Soil-to-plant concentration ratio for vegetative portions of plants (unitless).

$\mathrm{Br}=$ Soil-to-plant concentration ratio for reproductive portions (fruits, tubers) of plants (unitless).

DF = Dry weight fraction of plant $(0.066$ unitless).

$\mathrm{IRp}=$ Ingestion rate for garden produce $10.05 \mathrm{~kg}$ per day for vegetative parts; $0.03 \mathrm{~kg}$ per day for reproductive parts).

$\mathrm{Fl}=$ Fraction of garden produce ingested from contaminated source (1.0 unitless).

$\mathrm{EF}=$ Exposure frequency (350 days per year).

$E D=$ Exposure duration (50 years for an adult).

BW = Body weight $(70 \mathrm{~kg}$ for an adult).

$A T=$ Averaging time (365 days $\times$ ED for noncarcinogens, 365 days $\times 70$ years for carcinogens).

Exposure doses shawn are the sum of the vegetative parts plus the reproductive parts.

b This value is calculated by dividing the garden produce ingestion exposure dose by the ground water ingestion exposure dose.

'Value cannot be calculated because $\mathrm{Kd}$ is equal to zero.

${ }^{d}$ Picocuries per lifetime. 


\section{Table 4.3 Exposure dose calculations for ingestion of milk from ground water-fed livestock, Bowman, North Dakota, site}

\begin{tabular}{|c|c|c|c|c|c|c|}
\hline $\begin{array}{l}\text { Contaminant of } \\
\text { potential concern }\end{array}$ & $C_{w}$ & $\begin{array}{c}\mathrm{Kd} \\
(\mathrm{L} / \mathbf{k g})\end{array}$ & Bv & $\mathrm{Fm}$ & $\begin{array}{l}\text { Milk ingestion } \\
\text { exposure dose } \\
\text { (mg/kg-day) }\end{array}$ & $\begin{array}{c}\text { Ratio of milk } \\
\text { ingestion to water } \\
\text { ingestion }\end{array}$ \\
\hline \multicolumn{7}{|c|}{ Noncarcinogenic effects (mg/L) } \\
\hline $\begin{array}{l}\text { Arsenic } \\
\text { Molybdenum } \\
\text { Selenium } \\
\text { Sodium } \\
\text { Sulfate } \\
\text { Uranium } \\
\text { Vanadium }\end{array}$ & $\begin{array}{c}0.007 \\
0.64 \\
0.12 \\
1551 \\
5780 \\
0.33 \\
0.15\end{array}$ & $\begin{array}{c}19.4 \\
120 \\
14.9 \\
0.2 \\
0 \\
50 \\
100\end{array}$ & $\begin{array}{l}0.04 \\
0.25 \\
0.025 \\
0.075 \\
0.5 \\
0.0085 \\
0.0055\end{array}$ & $\begin{array}{l}0.00006 \\
0.0015 \\
0.004 \\
0.035 \\
0.005 \\
0.0006 \\
0.00002\end{array}$ & $\begin{array}{r}1 E-07 \\
3 E-03 \\
1 E-04 \\
1 E+01 \\
7 E+00 \\
7 E-05 \\
1 E-06\end{array}$ & $\begin{array}{l}0.0005 \\
0.15 \\
0.03 \\
0.25 \\
0.03 \\
0.007 \\
0.0003\end{array}$ \\
\hline \multicolumn{7}{|c|}{ Carcinogenic effects (pCi/L) } \\
\hline $\begin{array}{l}\text { Arsenic }(\mathrm{mg} / \mathrm{L}) \\
\text { Radium-226 } \\
\text { Uranium }\end{array}$ & $\begin{array}{l}0.007 \\
3.0 \\
226\end{array}$ & $\begin{array}{l}19.4 \\
100 \\
50\end{array}$ & $\begin{array}{l}0.040 \\
0.015 \\
0.0085\end{array}$ & $\begin{array}{l}0.00006 \\
0.00045 \\
0.0006\end{array}$ & $\begin{array}{c}2 E-07 \\
1 E+03^{b} \\
8 E+04^{b}\end{array}$ & $\begin{array}{l}0.002 \\
0.005 \\
0.008\end{array}$ \\
\hline
\end{tabular}

Equation definitions for exposure dose calculations

Ingestion of milk from ground water-fed livestock

Chemicals

Chronic daily intake $(\mathrm{mg} / \mathrm{kg}$-day $)=\frac{\mathrm{Cm} \times \mathrm{IRm} \times \mathrm{FI} \times \mathrm{EF} \mathrm{EF}}{\mathrm{BW} \times \mathrm{AT}}$ BW $\times$ AT

\section{Radionuclides}

Lifetime intake $(\mathrm{pCi} /$ lifetime $)=\mathrm{Cm} \times \mathrm{IRm} \times \mathrm{FI} \times \mathrm{EF} \times \mathrm{ED}$

Where:

$\mathrm{CM}=$ Contaminant concentration in milk (mg/L), estimated using the following equation: $\mathrm{Cm}=\mathrm{Fm} \times([\mathrm{Qp} \times \mathrm{Cp}]+[\mathrm{Qs} \times \mathrm{Cs}]+[\mathrm{Q} w \times C w])$.

Where:

$\mathrm{Fm}=$ Feed-to-milk transfer coefficient (days per $\mathrm{kg}$ ).

Qp = The quantity of pasture eaten by cattle per day (19 kg per day).

Qs = The quantity of soil eaten by cattle per day $(0.38 \mathrm{~kg}$ per day).

$\mathrm{Qw}=$ The quantity of water consumed by cattle per day ( $56 \mathrm{~L}$ per day).

$\mathrm{Cp}=$ Contaminant concentration in pasture (milligrams per kilogram). $\mathrm{Cp}=\mathrm{Kd} \times \mathrm{Cw} \times \mathrm{Bv}$.

Cs = Contaminant concentration in soil $(\mathrm{mg} / \mathrm{kg})$. Cs $=\mathrm{Kd} \times \mathrm{Cw}$.

$\mathrm{Cw}=$ Contaminant concentration in ground water (95 percent upper confidence limit for the mean) (milligrams per liter or picocuries per liter).

Kd = Soil-water partition coefficient (liters per kilogram); from PNL (1989).

BV = Soil-to-plant concentration ratio for vegetative portions of plants (unitless).

EF = Exposure frequency ( 350 days per year).

$E D=$ Exposure duration (50 years for an adult).

$B W=$ Body weight (70 kg for an adult).

AT = Averaging time (365 days $\times$ ED for noncarcinogens, 365 days $\times 70$ years for carcinogens).

$\mathrm{IRm}=$ Ingestion rate of milk $(0.3 \mathrm{~kg}$ per day).

$\mathrm{F}$ = Fraction of milk ingested from contaminated source (1.0 unitless).

a Calculated by dividing the milk ingestion exposure dose by the ground water ingestion exposure dose.

bicocuries per lifetime. 


\section{Table 4.4 Exposure dose calculations for ingestion of meat from ground water-fed livestock, Bowman, North Dakota, site}

\begin{tabular}{|c|c|c|c|c|c|c|}
\hline $\begin{array}{c}\text { Contaminant of } \\
\text { potential concern }\end{array}$ & Cw & $\begin{array}{c}\mathrm{Kd} \\
(\mathrm{L} / \mathrm{kg})\end{array}$ & Bv & $\mathbf{F f}$ & $\begin{array}{l}\text { Meat ingestion } \\
\text { exposure dose } \\
\text { (mg/kg-day) }\end{array}$ & $\begin{array}{c}\text { Ratio meat } \\
\text { ingestion to ground } \\
\text { water ingestion }\end{array}$ \\
\hline \multicolumn{7}{|c|}{ Noncarcinogenic effects (mg/L) } \\
\hline Arsenic & 0.007 & 19.4 & 0.040 & 0.002 & $1 E-06$ & 0.005 \\
\hline Molybdenum & 0.64 & 120 & 0.25 & 0.006 & $3 \mathrm{E}-03$ & 0.15 \\
\hline Selenium & 0.12 & 14.9 & 0.025 & 0.015 & $1 E-04$ & 0.03 \\
\hline Sodium & 1551 & 0.2 & 0.075 & 0.055 & $5 E+00$ & 0.125 \\
\hline Sulfate & 5780 & 0 & 0.5 & 0.1 & b & b \\
\hline Uranium & 0.33 & 50 & 0.0085 & 0.0002 & $6 \mathrm{E}-06$ & 0.0007 \\
\hline Vanadium & 0.15 & 100 & 0.0055 & 0.0025 & $4 \mathrm{E}-05$ & 0.01 \\
\hline \multicolumn{7}{|c|}{ Cercinogenic effects (pCi/L) } \\
\hline Arsenic (mg/L) & 0.007 & 19.4 & 0.040 & 0.002 & $8 \mathrm{E}-07$ & 0.008 \\
\hline Radium-226 & 3.0 & 100 & 0.015 & 0.00025 & $1 E+02^{c}$ & 0.0005 \\
\hline Uranium & 226 & 50 & 0.0085 & 0.0002 & $7 E+03^{C}$ & 0.0007 \\
\hline
\end{tabular}

Equation definitions for exposure dose calculations

Ingestion of meat from ground water-fed livestock

Chemicals

Chronic daily intake $(\mathrm{mg} / \mathrm{kg}$-day $=\underline{\mathrm{Cb} \times \mathrm{IRb} \times \mathrm{FI} \times \mathrm{EF} \times \mathrm{ED}}$ BW $\times$ AT

Radionuclides

Lifetime intake $(\mathrm{pCi} /$ lifetime $)=\mathrm{Cb} \times \mathrm{IRb} \times \mathrm{FI} \times \mathrm{EF} \times \mathrm{ED}$

Where:

$\mathrm{Cb}=$ Contaminant concentration in beef (milligram per kilogram), estimated using the following equation: $\mathrm{Cb}=\mathrm{Ff} \times([\mathrm{Qp} \times \mathrm{Cp}]+[\mathrm{Qs} \times \mathrm{Cs}]+[\mathrm{Qw} \times \mathrm{Cw}])$.

Where:

Ff = Feed-to-flesh transfer coefficient (days per kilogram).

$\mathrm{Qp}=$ The quentity of pasture eaten by cattle per day (19 $\mathrm{kg}$ per day).

Qs = The quantity of soil eaten by cattle per day $(0.38 \mathrm{~kg}$ per day).

$\mathrm{Qw}$ = The quentity of water consumed by cattle per day (56 $L$ per day).

$\mathrm{Cp}_{\mathrm{p}}=$ Contaminant concentration in pasture (milligram per kilogram). $\mathrm{Cp}=\mathrm{Kd} \times \mathrm{Cw} \times \mathrm{Bv}$.

$\mathrm{Cs}=$ Contaminant concentration in soil (milligram per kilogram). $\mathrm{Cs}=\mathrm{Kd} \times \mathrm{Cw}$.

$\mathrm{CW}_{\mathrm{w}}=$ Contaminant concentration in ground water (95 percent upper confidence limit for the mean) (milligrams per liter or picocuries per liter).

Kd = Soil-water partition coefficient (liters per kilogram); from PNL (1989).

Bv = Soil-to-plant concentration ratio for vegetative portions of plants (unitless).

$E F$ = Exposure frequency (350 days per year).

$E D=$ Exposure duretion (50 years for an adult).

$B W=$ Body woight $(70 \mathrm{~kg}$ for an adult).

AT = Averaging time (365 days $\times$ ED for noncarcinogens, 365 days $\times 70$ years for carcinogens).

$\mathrm{IRb}=$ Ingestion rate of meat $(0.075 \mathrm{~kg}$ per day).

$\mathrm{Fl}=$ Fraction of meat ingested from contaminated source (1.0 unitless).

- Calculated by dividing the meat ingestion exposure dose by the ground water ingestion exposure dose.

bValue cannot be calculated because $K d$ is equal to zero.

CPicocuries per lifetime. 


\subsection{EXPOSURE CONCENTRATIONS}

The exposure concentration of a contaminant in ground water is the concentration taken in by an individual over the period of exposure considered. In this evaluation, contaminant concentrations are assumed to remain in a steady state (i.e., not trending up or down with time) during the assumed residence periods for chronic exposure. Actual contaminant concentrations and therefore, exposures, are expected to decrease with time after the removal of soil contamination. Nonetheless, these estimates are used conservatively for chronic exposure under current on-site conditions which may actually overestimate risk.

This evaluation of noncarcinogenic risks presents exposure concentrations as probabilities of occurrence based on ground water data collected from monitor wells 502, 503, and 517 for the contaminants of potential concern. These wells are on-site (where ashing occurred) and have consistently shown the highest concentrations of most constituents. Theoretical probability distributions for concentration were selected for the inorganic contaminants of potential concern in the shallow ground water system (arsenic, selenium, sodium, sulfate, molybdenum, uranium, and vanadium). Each distribution was selected to approximate the same mean, median, standard deviation, and shape as those observed in historical water quality data. The software package @RISK (Palisade Corp., 1992) was used to simulate these distributions (Figures 4.2 through 4.8 ). The upper limit of the distribution was set at a value slightly higher than the maximum observed concentration.

The radionuclide concentrations are represented by the maximum concentration reported in Table 3.2. Using the maximum observed concentrations for radionuclides may overestimate exposure and the potential carcinogenic risks. Maximum values were used because the available dataset is limited.

\subsection{ESTIMATION OF INTAKE THROUGH DRINKING WATER}

Within the population of future residents, individuals are expected to vary with respect to water consumption habits, stable body weight, and length of time they reside in the potential contamination zone. Consequently, exposure associated with ground water consumption will vary among members of this population. To adequately describe the range of potential future risks to the population, naturally occurring variability in daily water intake and body weight were incorporated into the intake estimation.

The potential toxicity of noncarcinogenic contaminants in drinking water depends primarily on long-term average daily consumption of the contaminant per kilogram of body weight measured in milligrams per kilogram per day $(\mathrm{mg} / \mathrm{kg}$-day). The following equation estimates chronic daily intake: 

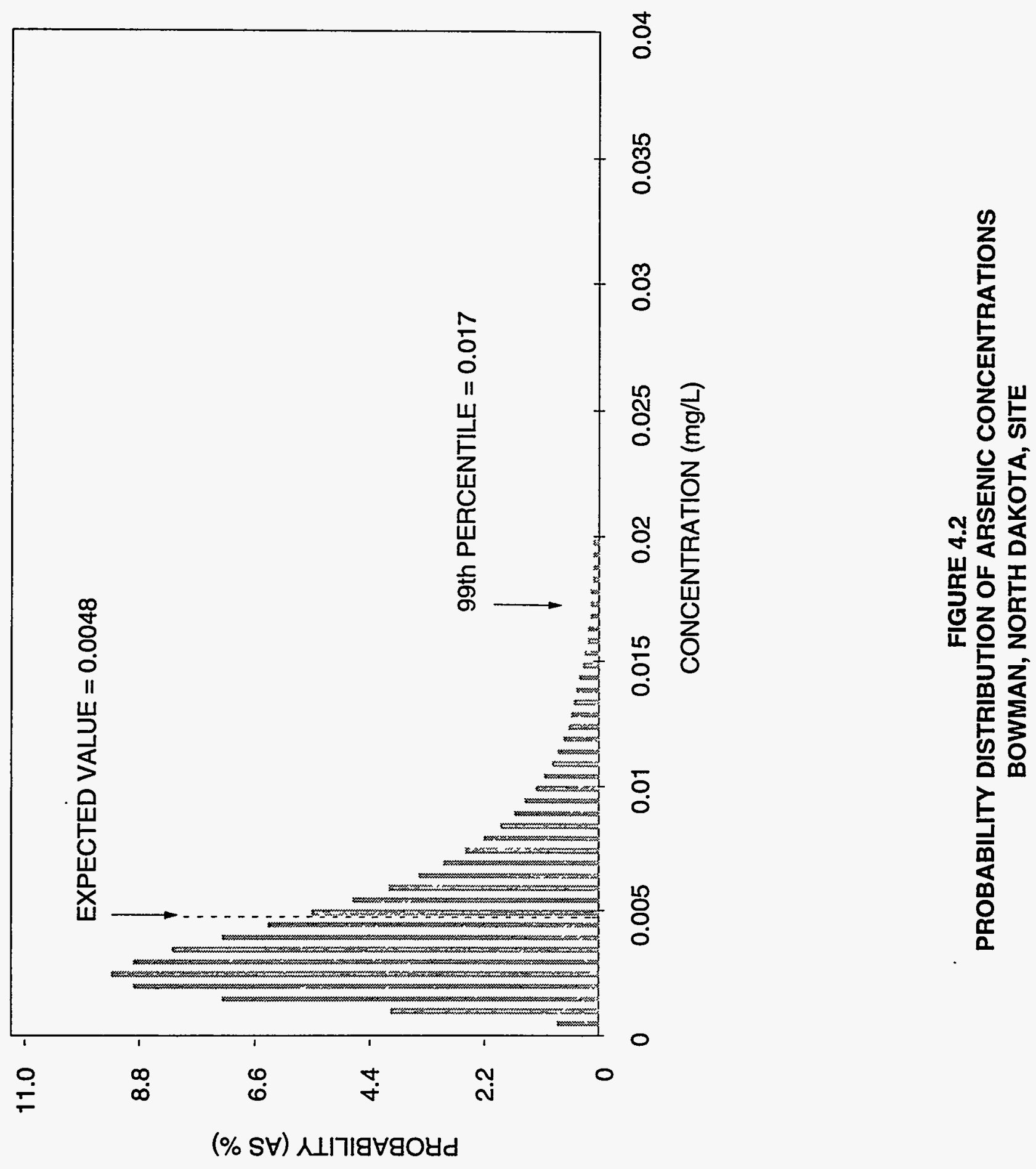

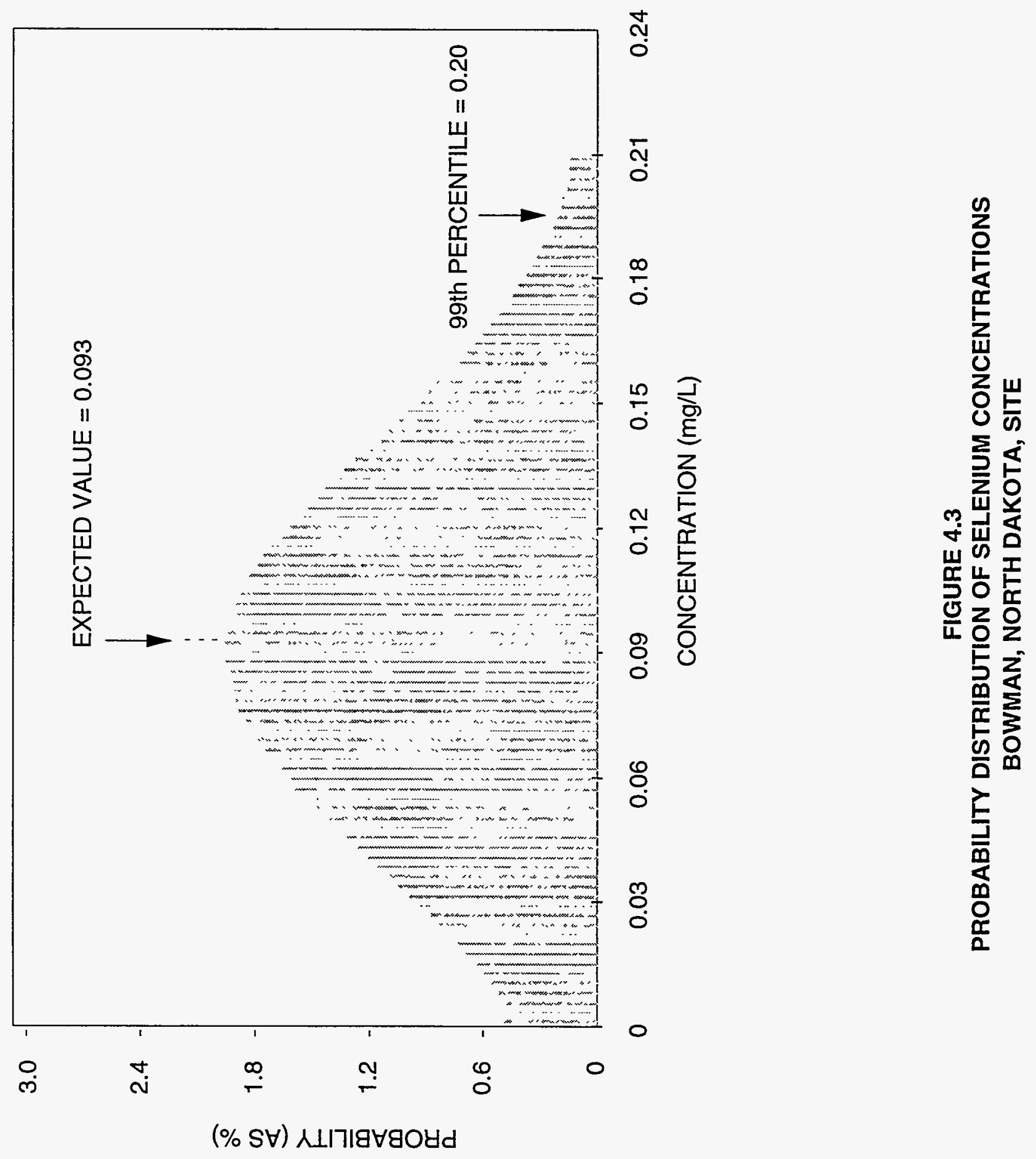

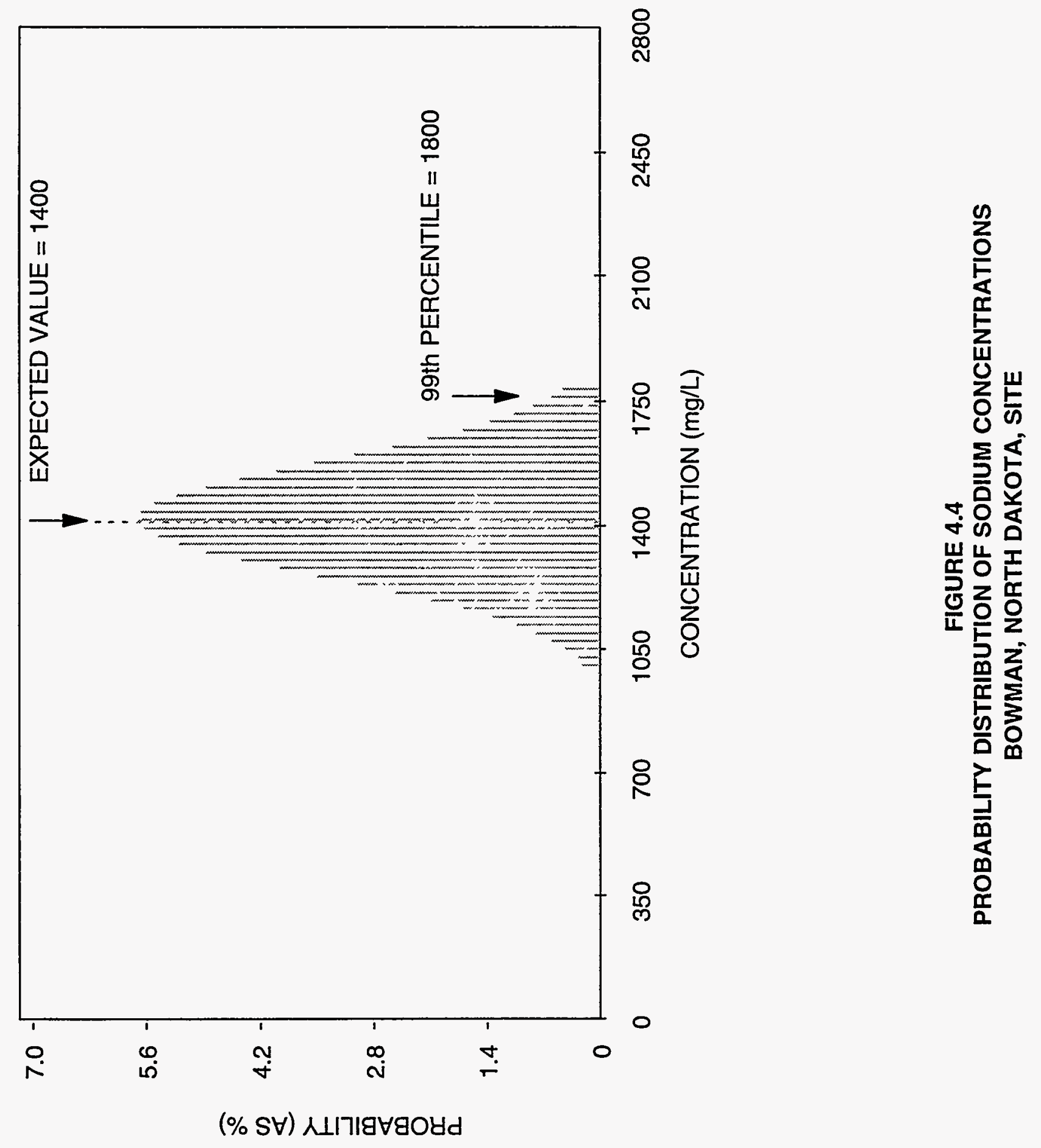


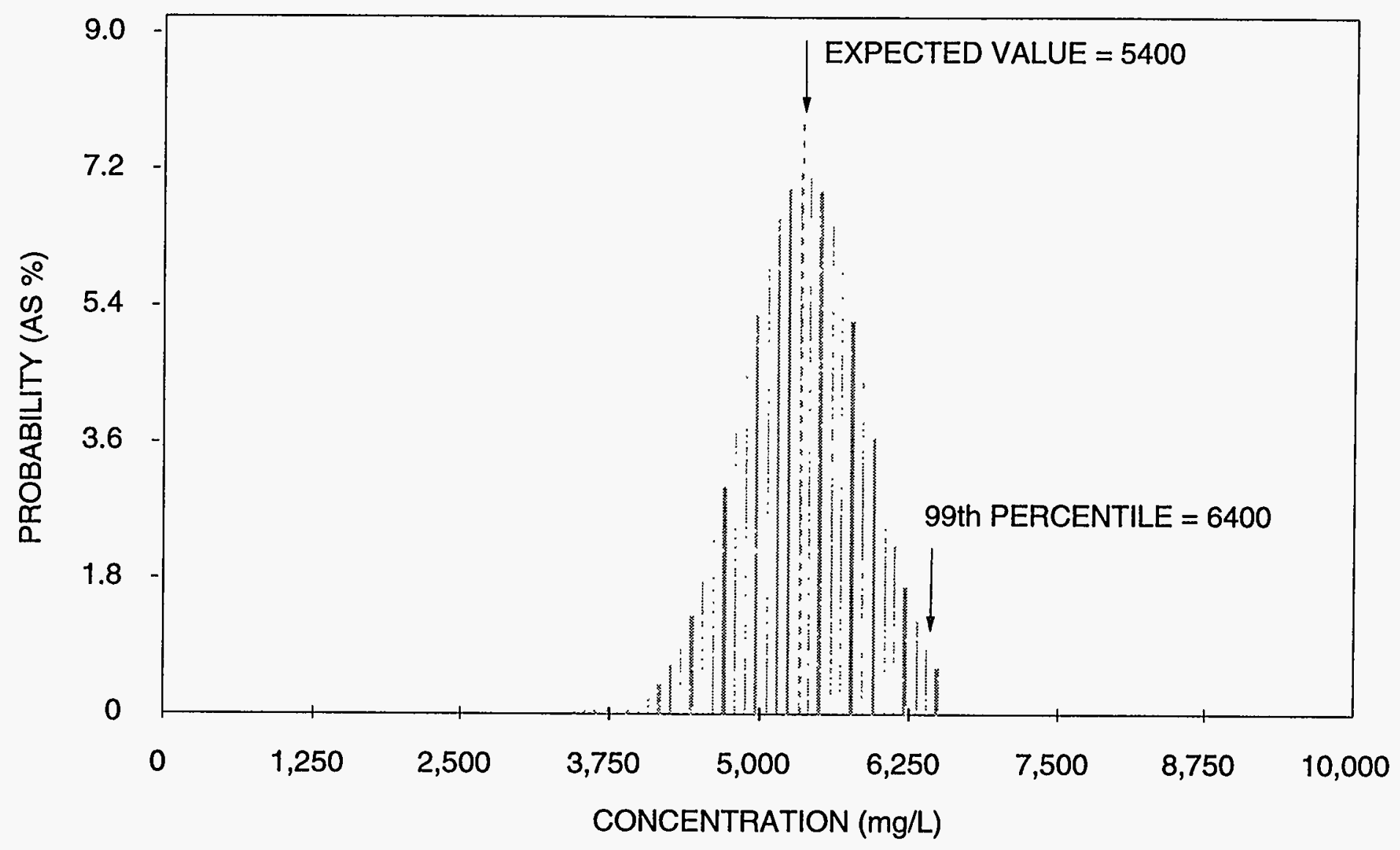

FIGURE 4.5

PROBABILITY DISTRIBUTION OF SULFATE CONCENTRATIONS

BOWMAN, NORTH DAKOTA, SITE 


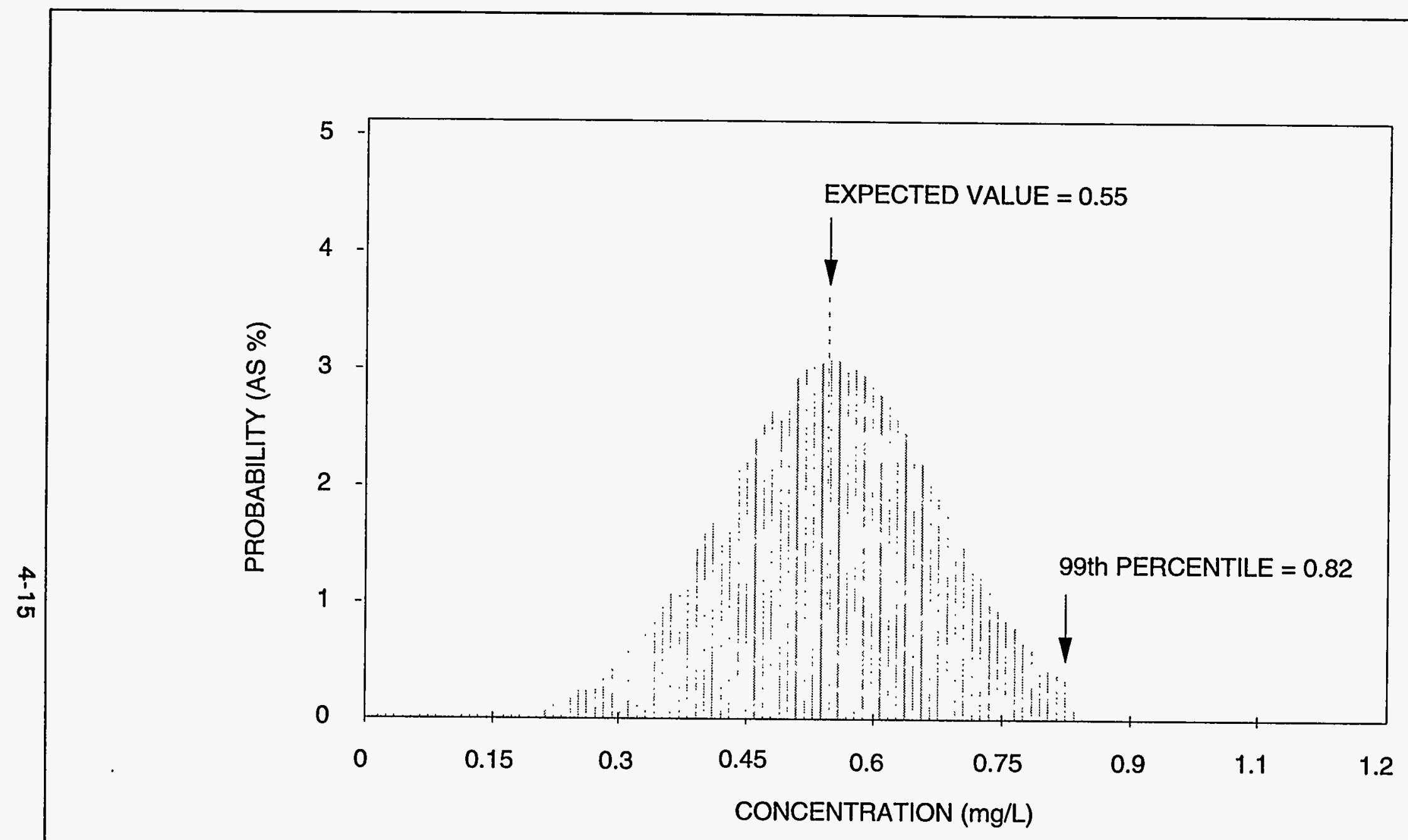

FIGURE 4.6

PROBABILITY DISTRIBUTION OF MOLYBDENUM CONCENTRATIONS BOWMAN, NORTH DAKOTA, SITE 

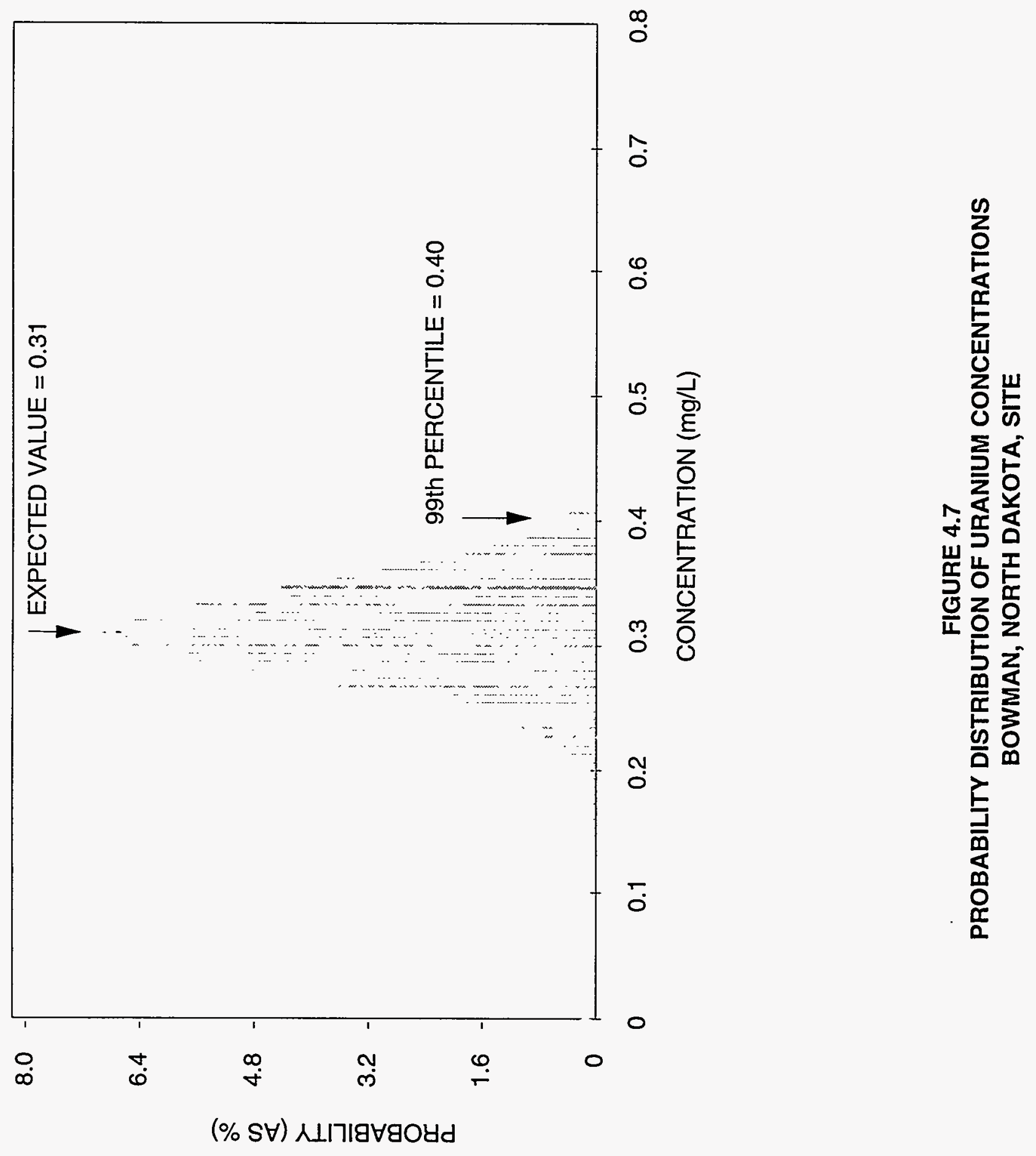


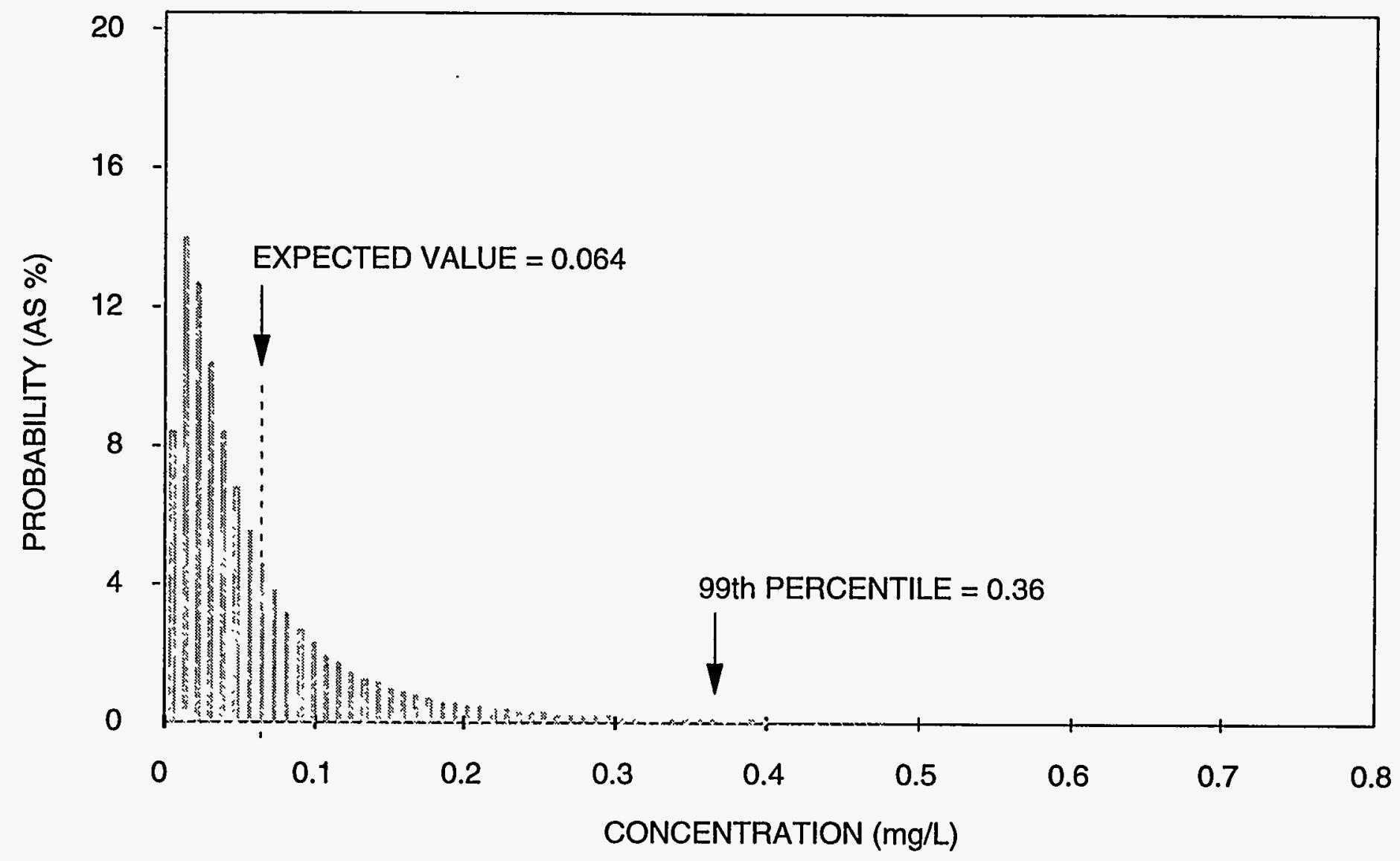

FIGURE 4.8

PROBABILITY DISTRIBUTION OF VANADIUM CONCENTRATIONS

BOWMAN, NORTH DAKOTA, SITE 


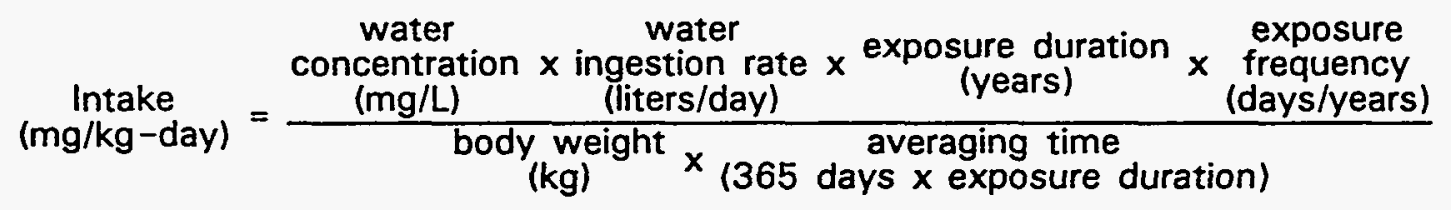

Intake for chemical carcinogens is based on the average daily consumption of the chemical per kilogram of body weight but it is averaged over a lifespan of 70 years. Arsenic intake over a lifetime is calculated as follows:

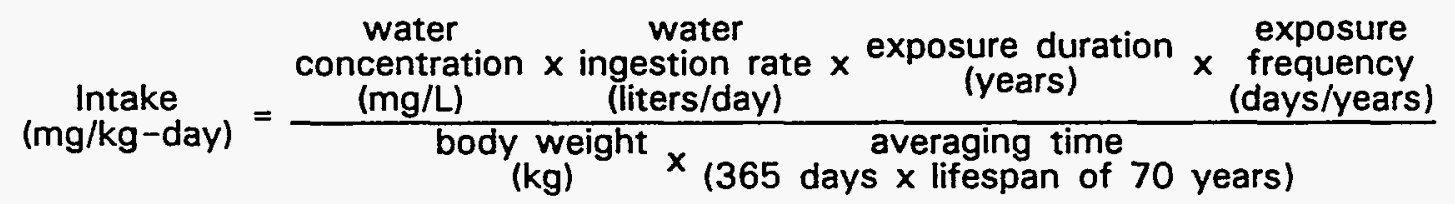

Potential carcinogenicity of radioactive carcinogens is additive lincreases with total intake over time). Also, body weight is relatively insignificant in determining risk from exposure to radioactive carcinogens. Intake of a radioactive carcinogenic substance is quantified as total exposure (measured in picocuries) to radioactivity times the exposure duration:

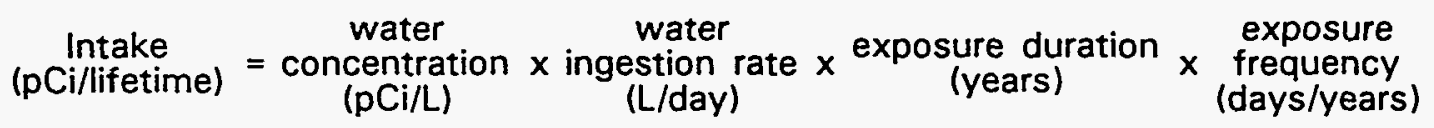

\section{Average daily water intake (liters per day)}

Lognormal probability distributions were used to describe variation in average daily tap water intake among members of the population (Roseberry and Burmaster, 1992). These distributions were developed from data collected during the 1977-78 National Food Consumption Survey conducted by the U.S. Department of Agriculture. During the survey, total tap water consumption during a 3-day period was recorded for 26,081 survey participants nationwide (Figure 4.9).

\section{Body weight (kilograms)}

Extensive national data on weights of males and females, by age, were collected by the National Health and Nutrition Survey between 1976 and 1980. These data were used to develop lognormal probability distributions for body weight by age for each sex. The distributions for males and females were then combined using census data on the national ratio of males to females within each age group (Figure 4.10). 


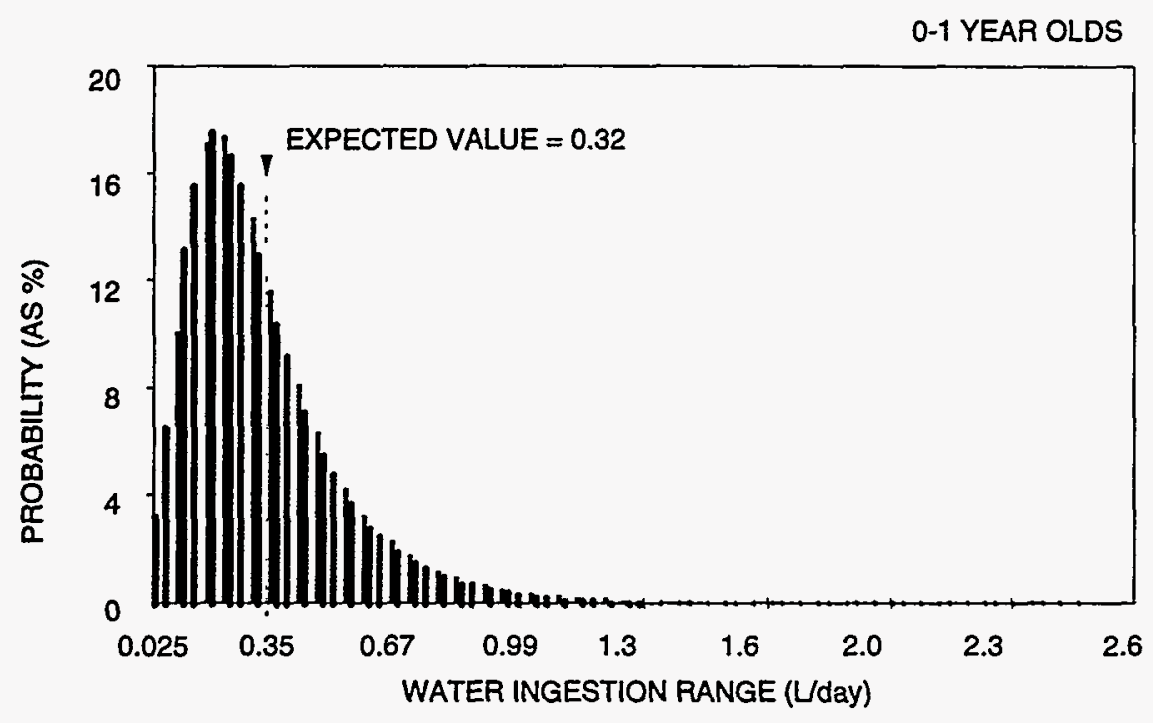

1-10 YEAR OLDS
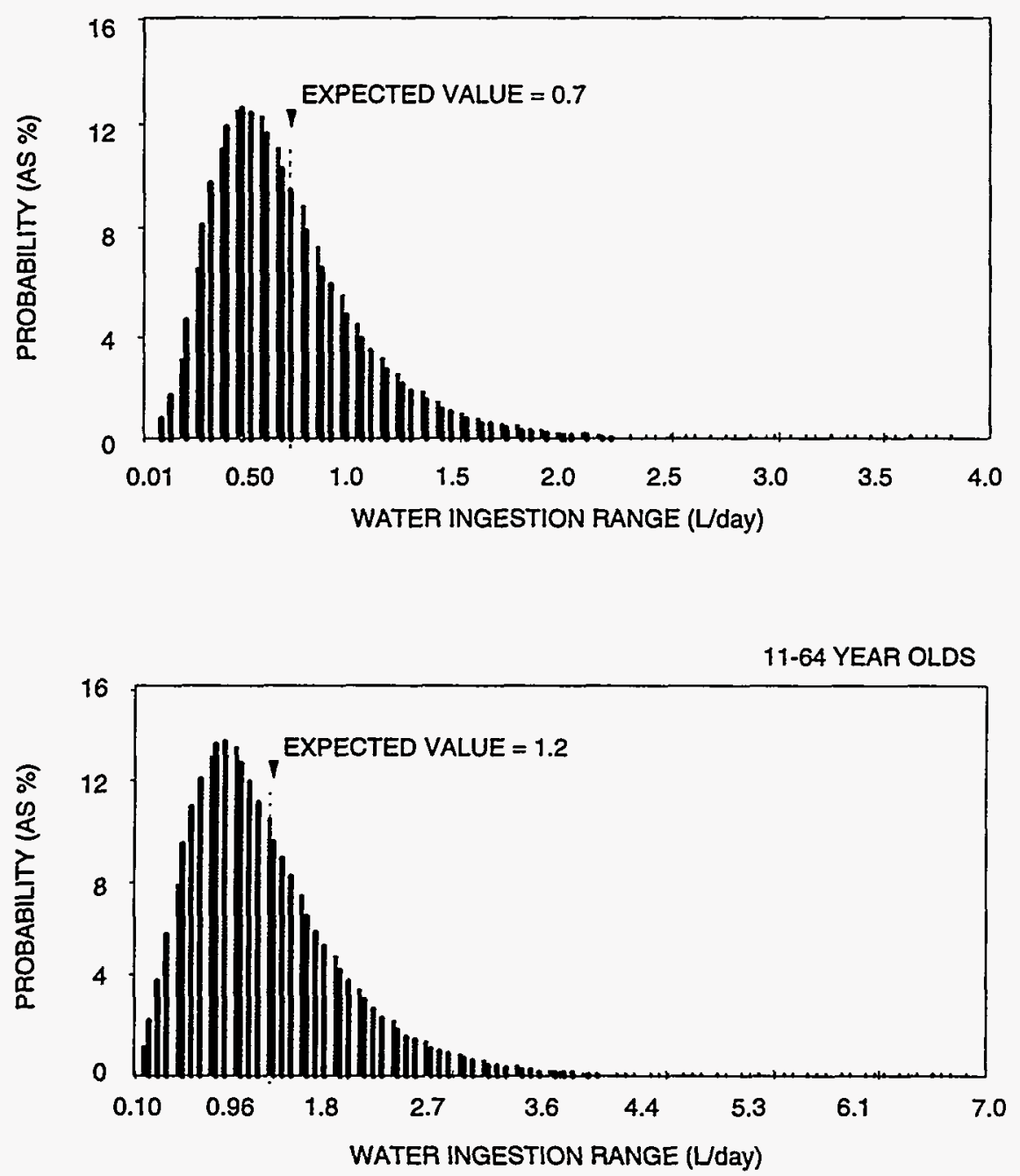

FIGURE 4.9

PROBABILITY DISTRIBUTIONS FOR TAP WATER INGESTION RATES 


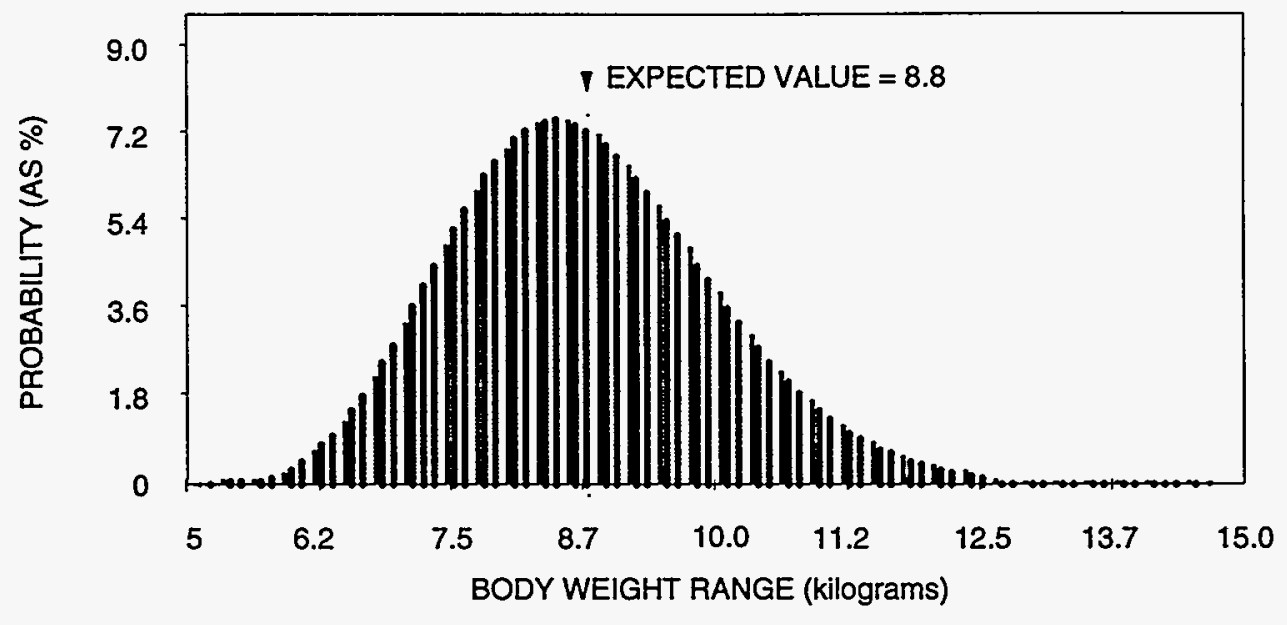

1-10 YEAR OLDS
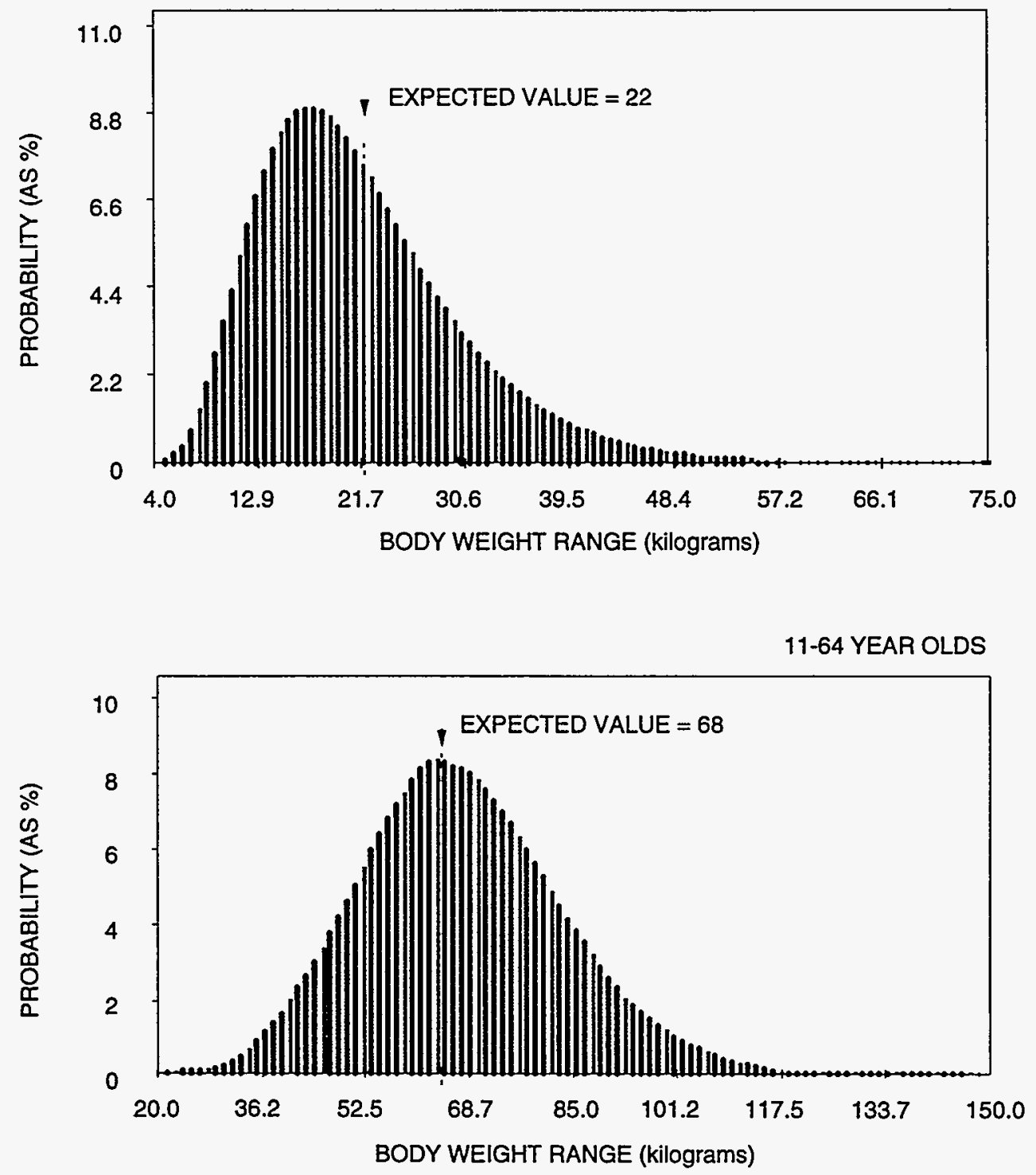

FIGURE 4.10

PROBABILITY DISTRIBUTIONS FOR BODY WEIGHT 


\section{Exposure frequency (days)}

Individuals generally are not in their homes and drinking water from the same source for 365 days per year. Therefore, calculation of intake assumes only 350 days exposure per year, allowing 2 weeks per year of drinking-water intake from a different source (EPA, 1991). Because exposure is expressed and compared in terms of average daily intake, 365 days per year is retained as the averaging time.

\section{Exposure duration (years)}

An exposure duration of 50 years is used for the Bowman site because the area is rural (EPA, 1991). In both the numerator and the denominator of the intake equation, the exposure duration for noncarcinogens, assuming all exposures are chronic (at least 7 years), does not affect the results. However, exposure duration in the intake equation for chemical carcinogens is averaged over a lifetime. Total exposure for radiological carcinogens is proportional to the exposure duration. Chronic exposure for an infant or child is the age of that population. In addition, for potential acutely toxic contaminants, exposure would be based on an acute dose.

\section{Exposed population}

Intake dose probability distributions for each of the three populations were estimated using contaminant probability distributions for concentration and intake parameter probability distributions for body weights and ingestion rates. The 1-to 10-year-old age group consistently showed the highest intake-to-body weight distributions and is, therefore, the most conservative age group to evaluate. The 0 - to 1 -year-old (infant) population is known to be sensitive to sulfate exposure. Therefore, the 0 - to 1 -year-old age group was used to evaluate sulfate intakes. Probability distributions representing estimated intakes for children of the contaminants of potential concern are shown in Figures 4.11 through 4.17. The probability distribution for total lifetime intake for adults for arsenic (a potential chemical carcinogen) and uranium (a potential radioactive carcinogen) are presented in Figures 4.18 and 4.19).

\subsection{EXPOSURE ASSESSMENT UNCERTAINTIES}

Several potential sources of error may arise in all phases of an exposure assessment, including the following more significant sources of uncertainty:

- Uncertainties resulting from the lack of thorough environmental sampling data (ground water, surface water, sediment, and biota), which could lead to an underestimate or overestimate in the exposure analysis.

- Uncertainties arising from the assumption that the ground water contaminant source term at the site has reached a steady state and that 


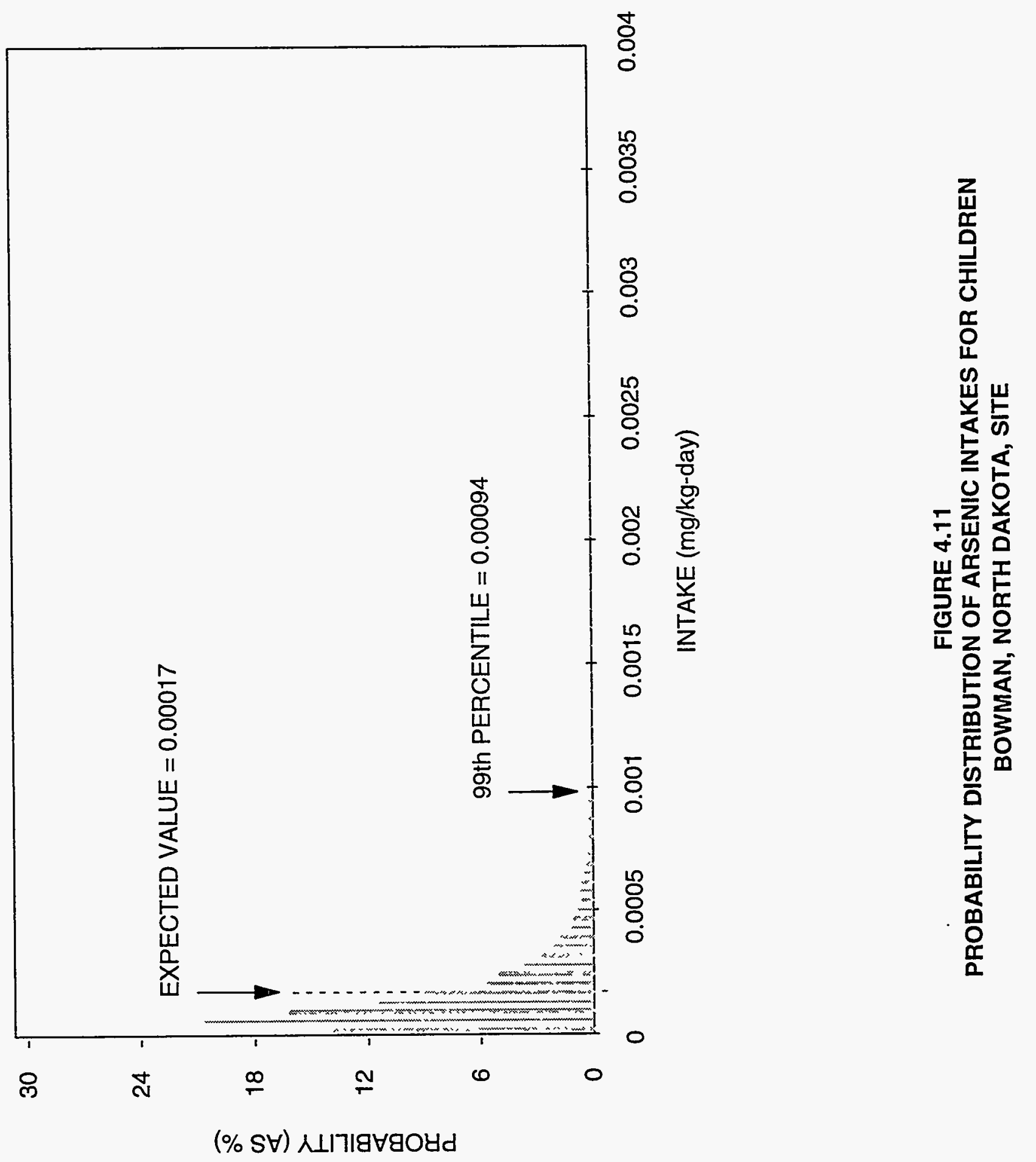



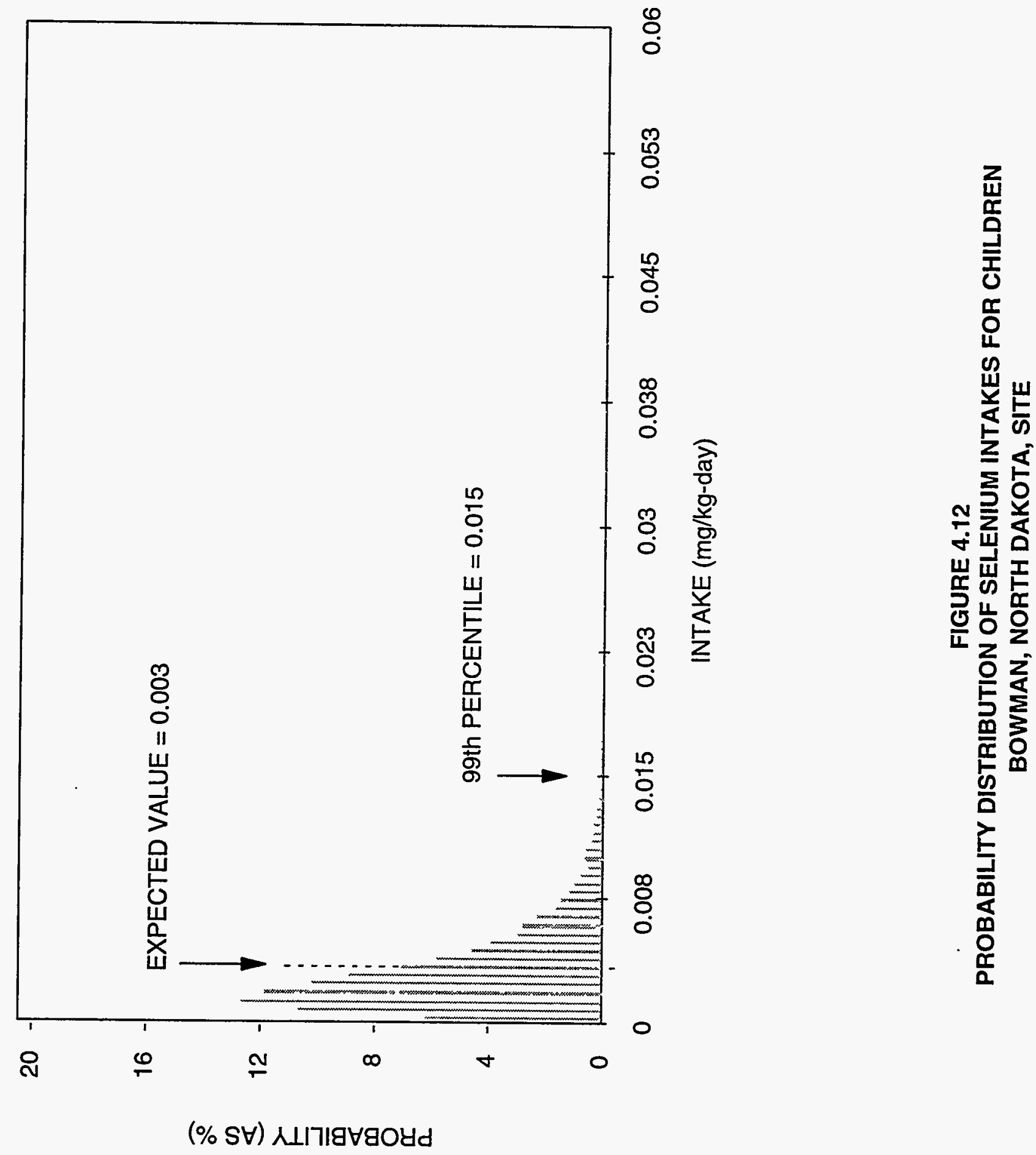


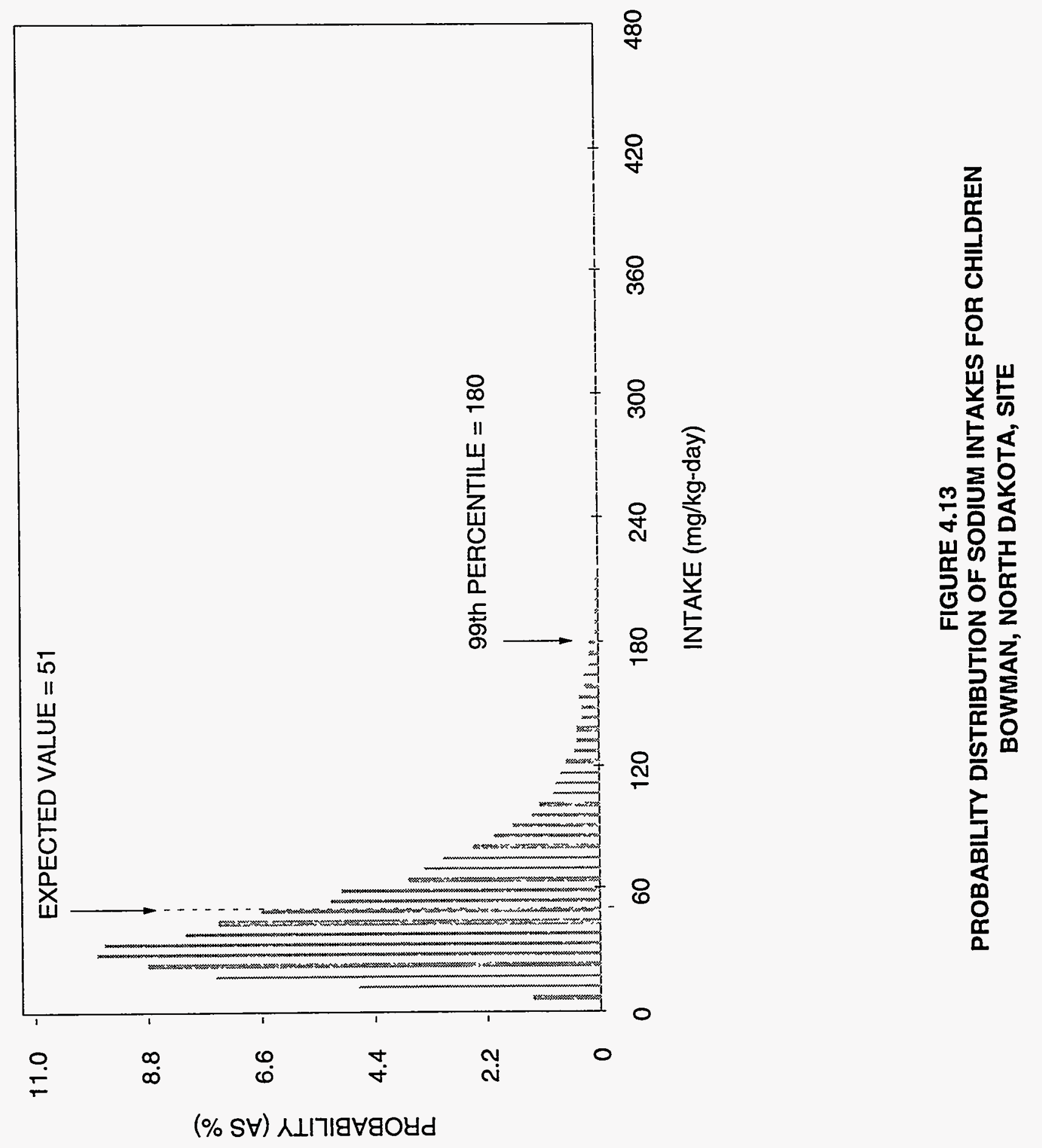




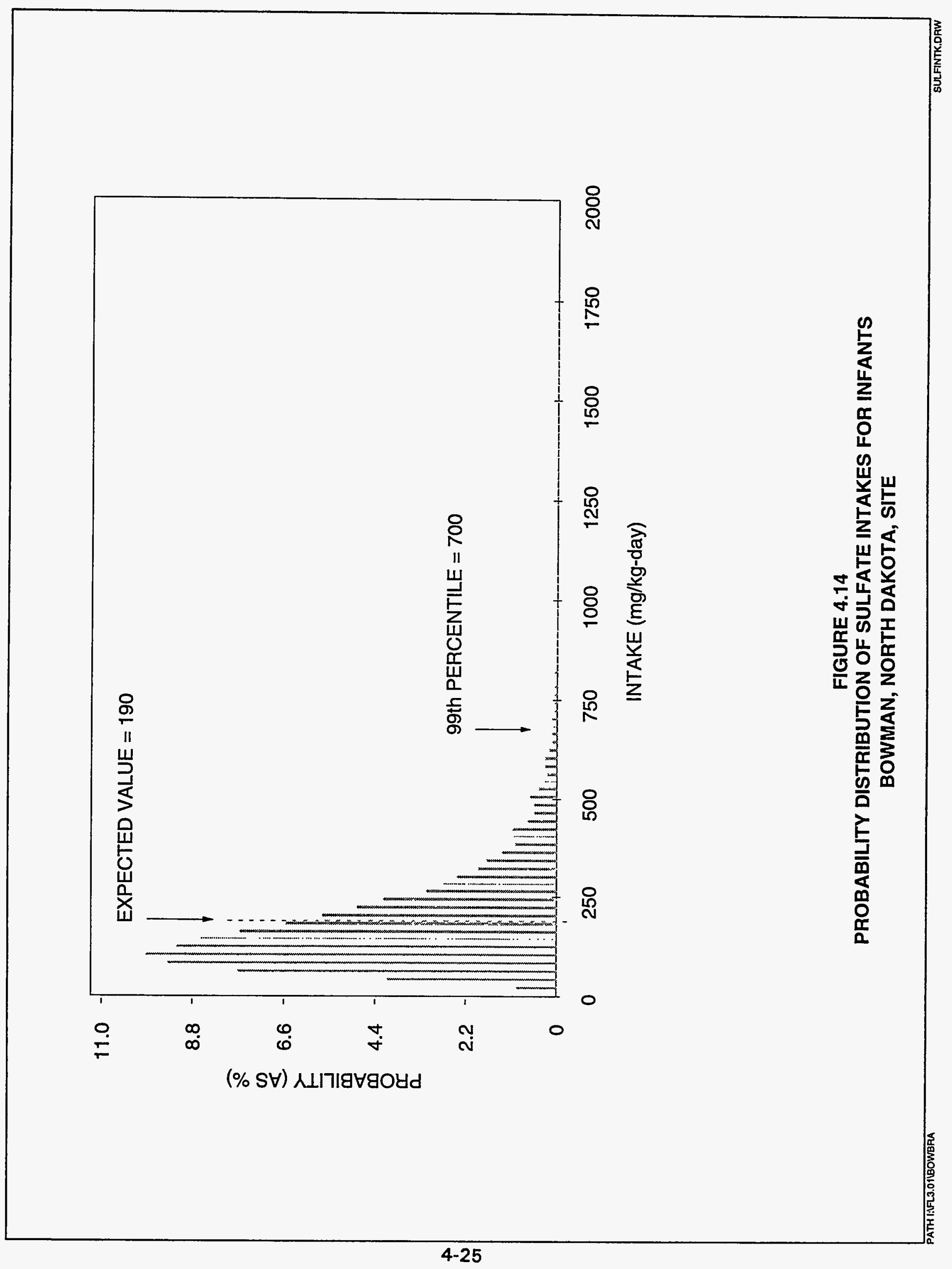




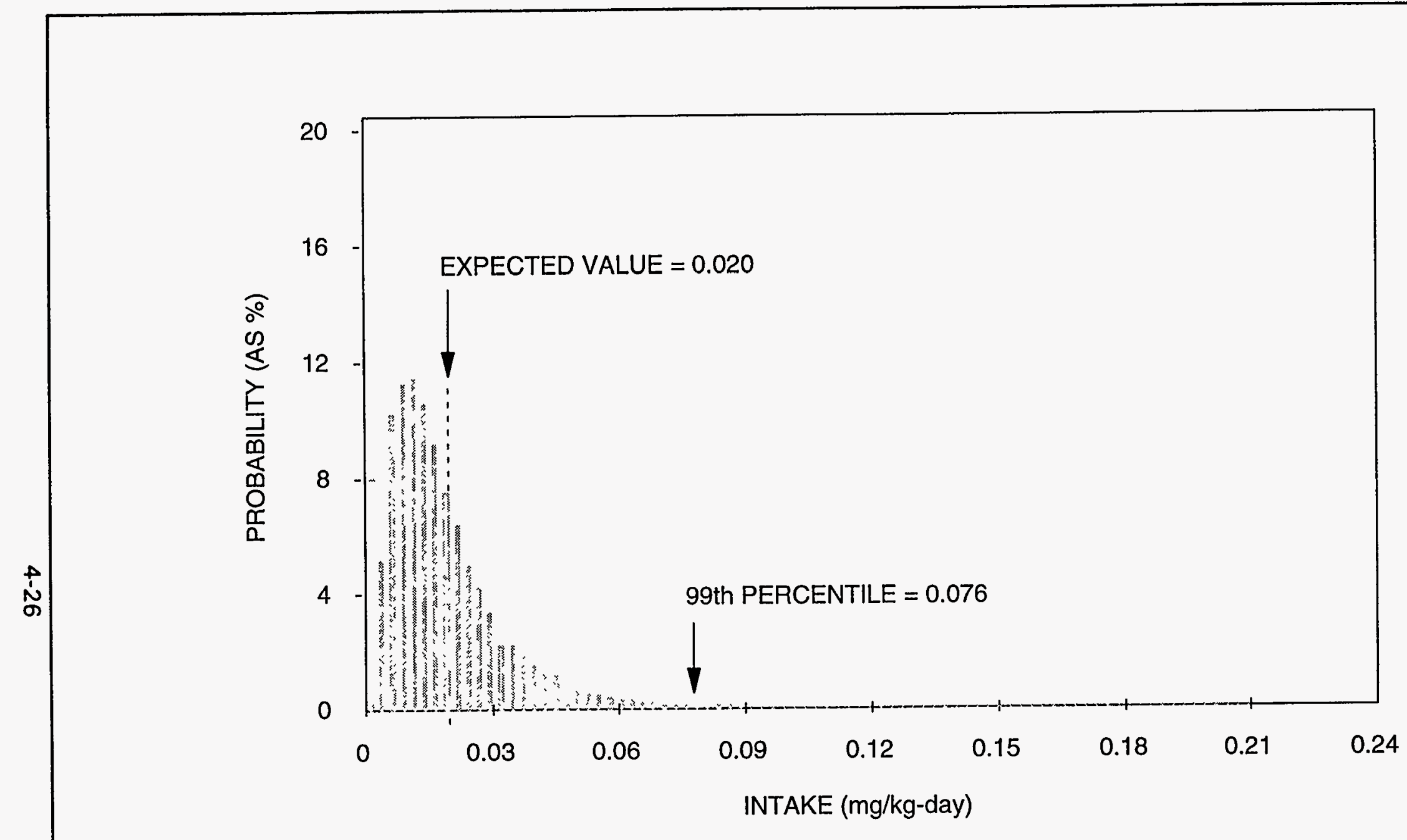

FIGURE 4.15

PROBABILITY DISTRIBUTION OF MOLYBDENUM INTAKES FOR CHILDREN BOWMAN, NORTH DAKOTA, SITE 

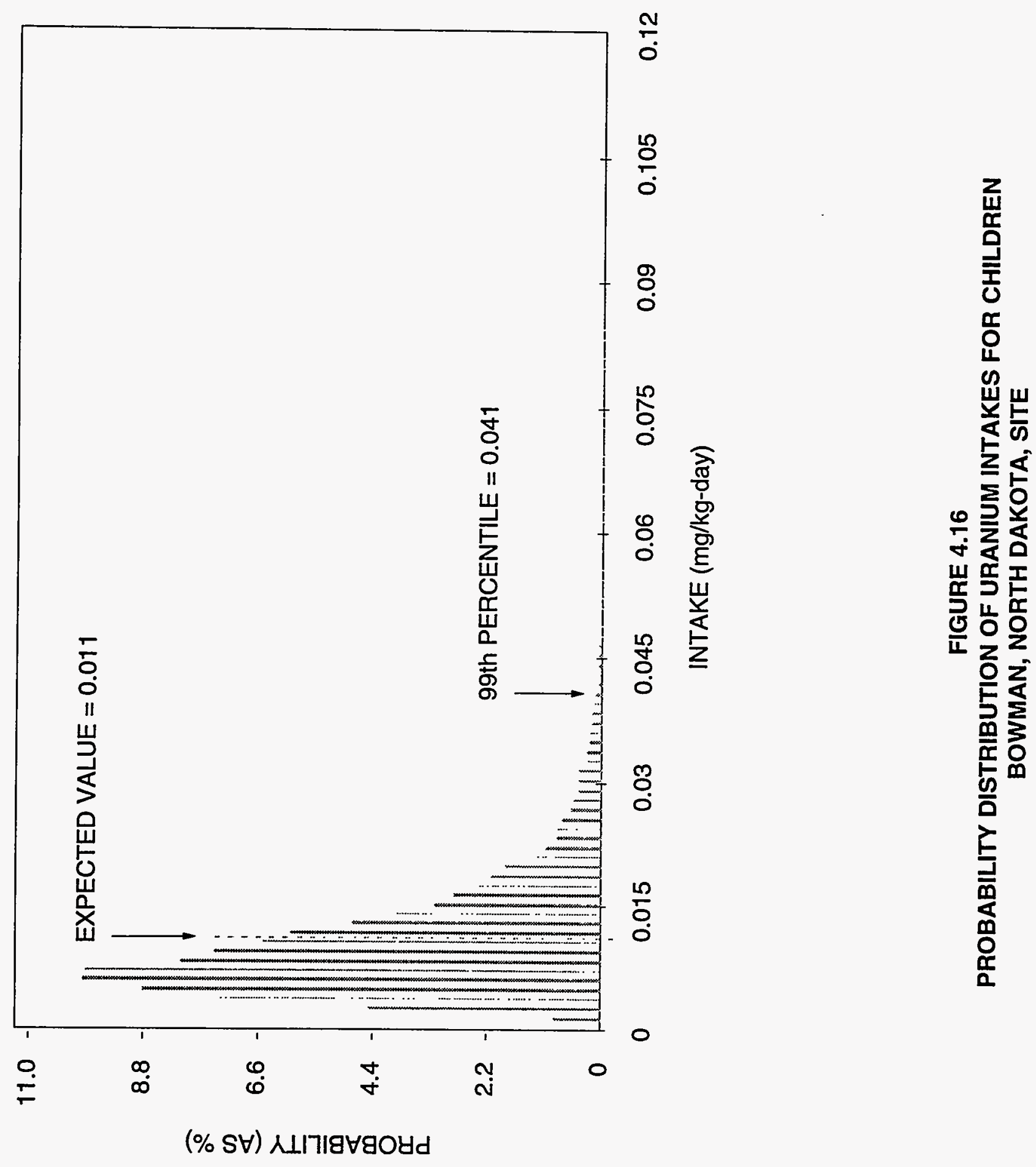


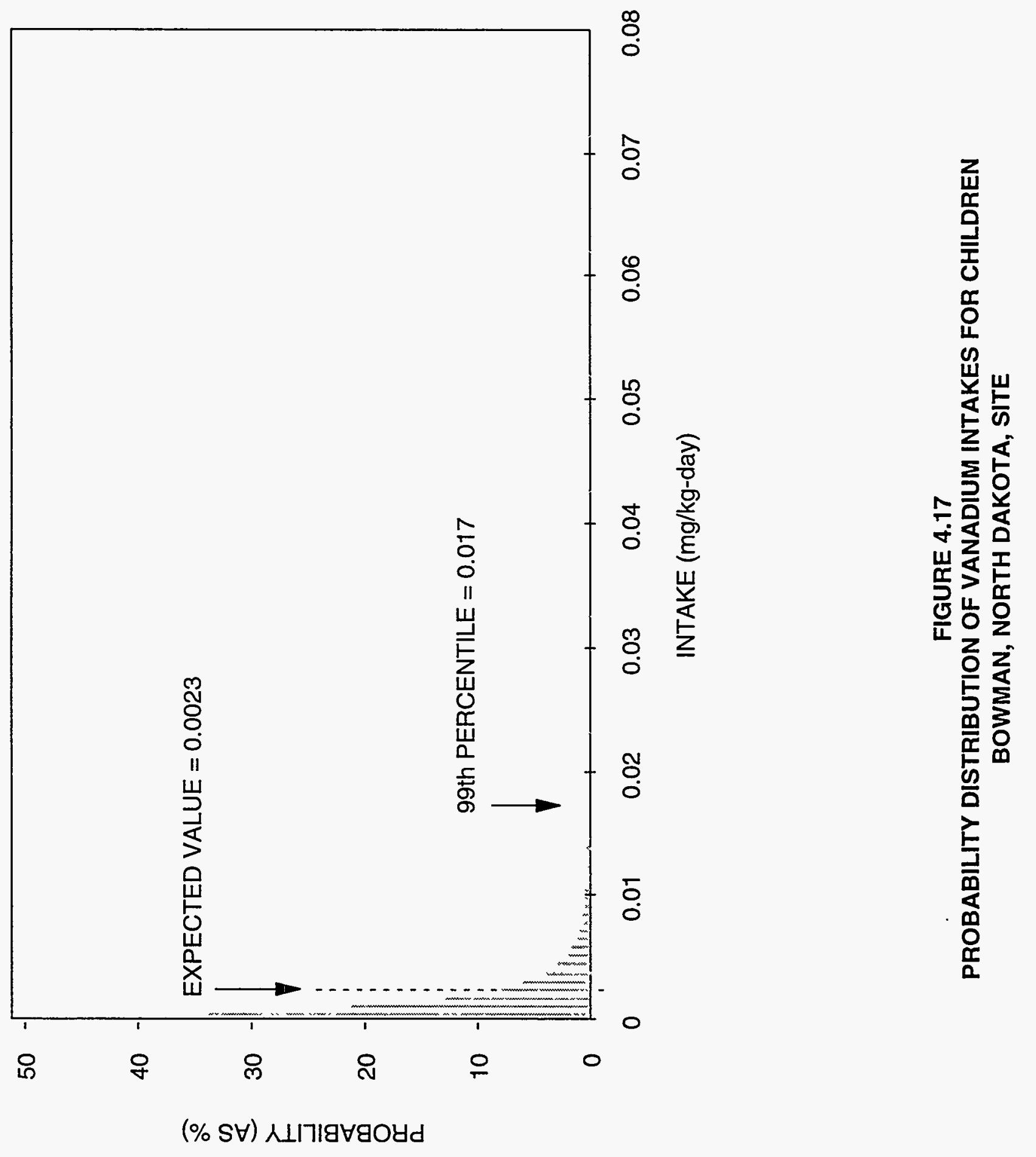



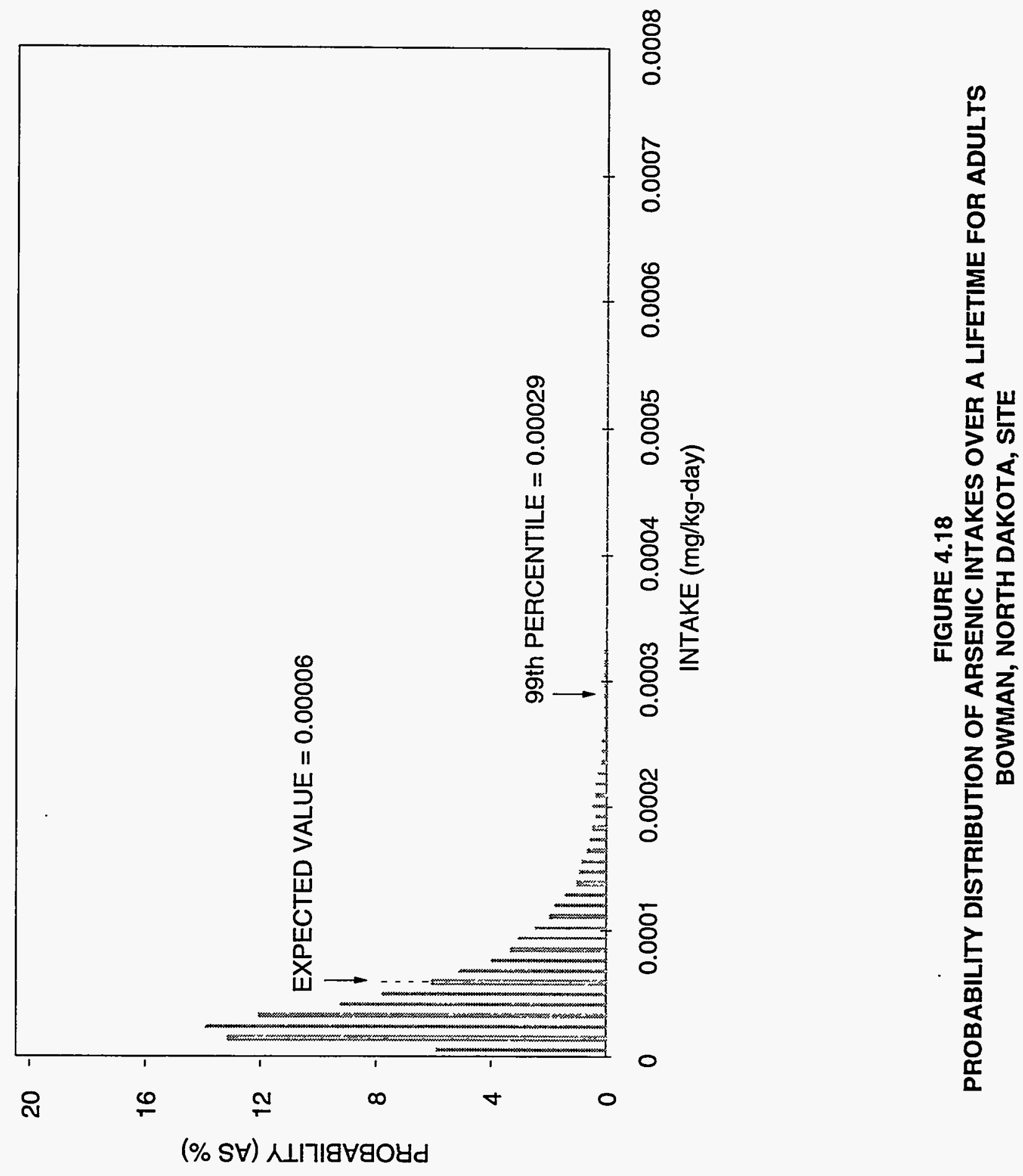

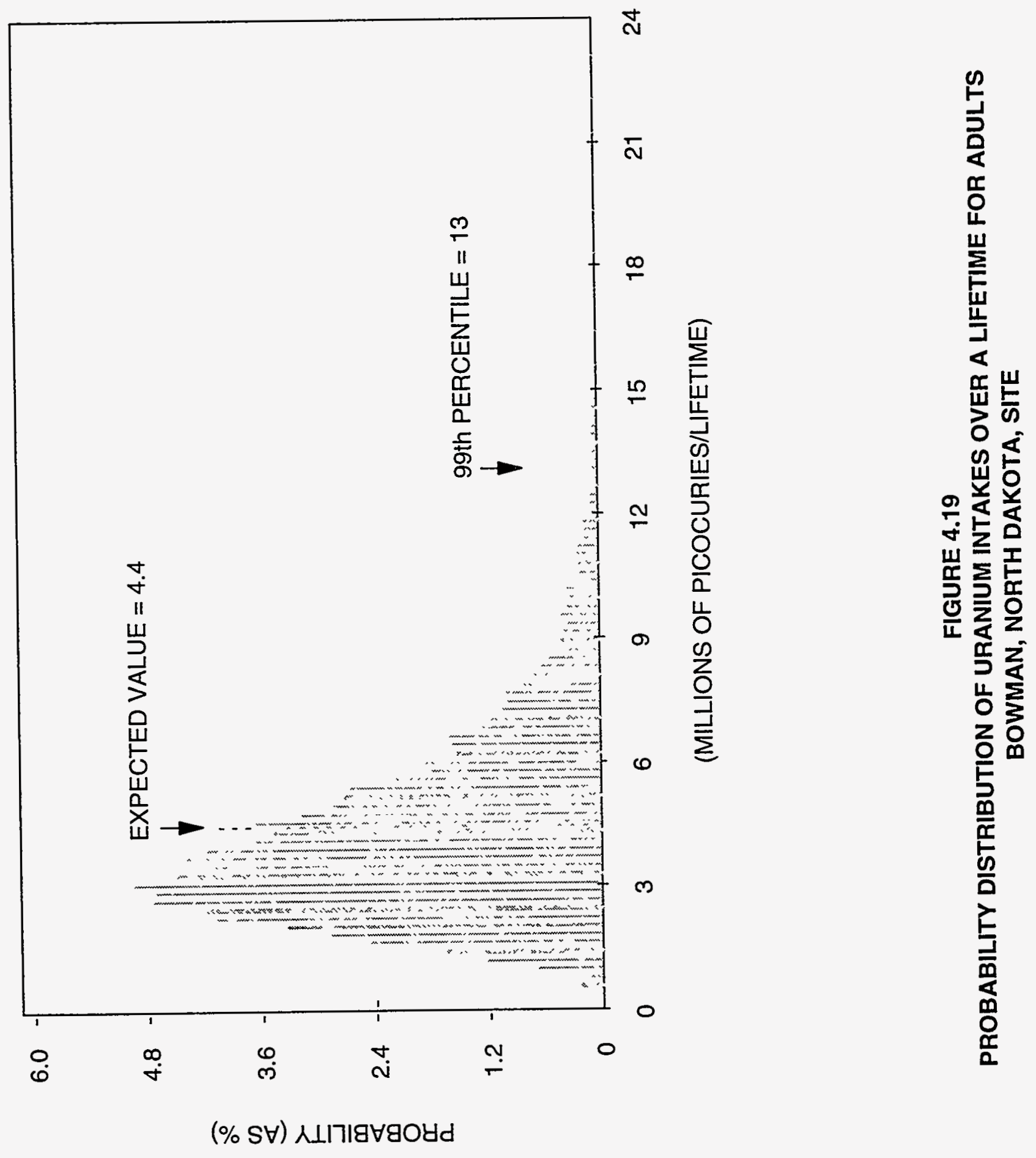
contaminant concentrations at the exposure point will remain constant for chronic periods of exposure (generally greater than 7 years).

- Uncertainties associated with the model used to estimate uptake of contaminants into plants for the irrigated garden produce pathway. Sitespecific plant uptake factors could vary substantially from the default literature estimates.

- Uncertainties with meat transfer coefficients for the milk and meat ingestion pathways. Site-specific transfer coefficients could vary substantially from the default literature values.

- Uncertainties associated with the relationship of an applied dose (used in this assessment) and absorbed dose or effective toxic dose for dermal absorption.

- Uncertainties associated with different sensitivities of subpopulations, such as individuals with chronic illnesses, that could alter predicted responses to contaminants.

Despite these uncertainties, probability distributions that incorporate definable sources of variability should provide a representative picture of the potential range of exposures. 


\subsection{TOXICITY ASSESSMENT}

Several site-related contaminants were identified in ground water at the Bowman site. This risk assessment evaluates the potential for the chronic ingestion of these contaminants to cause adverse human health and/or ecological effects. Any site-related impacts would overlap with the potential impacts from naturally occurring elements observed in background ground water. For comparison to the estimated contaminant intakes, the associated potential toxicological effects of the site-related chemical contaminants, including the carcinogenic potential of arsenic and the carcinogenic potential of uranium and its longer-lived radioactive decay progeny, are discussed below. The following source materials were used in developing these toxicological profiles: the Integrated Risk Information System (IRIS) (EPA, 1994a); EPA's Health Effects Assessment Summary Tables (HEAST) (EPA, 1994b); the Agency for Toxic Substances Disease Registry Toxicological Profiles, published by the Department of Health and Human Services (DHHS); the Handbook on the Toxicology of Metals (Friberg et al., 1986); and peerreviewed scientific literature. Basing toxicity information on these standardized review documents ensures evaluations at UMTRA Project sites are consistent with evaluations at sites regulated by different legislation.

The toxicity profiles presented here focus on drinking water source material in humans when available, including animal data only when human data are not available. Animal data are represented on the toxicity range graphs by widely spaced, dotted lines. Uncertainty about the beginning or ending points of a range of exposures that produces specific toxic effects are noted by closely spaced dots at the appropriate end of the line denoting range. Table 5.1 presents toxicity values for the noncarcinogenic effects of the contaminants of potential concern.

\subsection{CONTAMINANT TOXICITY SUMMARIES}

The basic toxicokinetics and toxicity of the noncarcinogenic contaminants of potential concern at the Bowman site (arsenic, selenium, sodium, sulfate, molybdenum, uranium, and vanadium) are presented below. Information on the radiological properties of natural uranium is also presented. Wherever possible, data from human studies are reported. Although these contaminants have a wide range of toxic effects depending on the exposure levels, the following discussions focus on toxic effects observed in the exposure ranges most relevant to contamination at the Bowman site.

\subsubsection{Arsenic}
Absorption
Arsenic is effectively absorbed through the gastrointestinal tract and by inhalation. Dermal absorption is negligible. In humans, approximately 80 percent of an ingested amount of dissolved inorganic trivalent (arsenite) or pentavalent arsenic (arsenate) is absorbed from the gastrointestinal tract (Pershagen and Vahter, 1979; Marafante and Vahter, 1987). 
Table 5.1 Toxicity values: potential noncarcinogenic effects

\begin{tabular}{|c|c|c|c|c|c|}
\hline Chemical & $\begin{array}{c}\text { Chronic oral RfD } \\
\text { (mg/kg-day) }\end{array}$ & $\begin{array}{c}\text { Confidence } \\
\text { level }\end{array}$ & $\begin{array}{c}\text { Critical } \\
\text { effect/organ }\end{array}$ & $\begin{array}{l}\text { RfD basis/ } \\
\text { RfD source }\end{array}$ & $\begin{array}{c}\text { Uncertainty } \\
\text { factor }\end{array}$ \\
\hline Antimony & 0.0004 & Low & $\begin{array}{l}\text { Increased } \\
\text { mortality/altered } \\
\text { blood chemistries }\end{array}$ & Water/HEAST & 1000 \\
\hline Arsenic & 0.0003 & High & $\begin{array}{l}\text { Kertosis, } \\
\text { hyperpigmentation }\end{array}$ & Water/HEAST & 3 \\
\hline Cadmium & 0.0005 & High & Kidney & Water/HEAST & 10 \\
\hline Lead & NA & NA & $\begin{array}{l}\text { Central nervous } \\
\text { system effects }\end{array}$ & NA & NA \\
\hline Molybdenum & 0.005 & High & Bone & Water/HEAST & 2 \\
\hline Selenium & 0.005 & High & Hair, nail, and skin & Diet/IRIS & 3 \\
\hline Sodium & NA & High & Hypertension & Water/diet & NA \\
\hline Sulfate & NA & High & Diarrhea & Water/NA & NA \\
\hline Uranium & 0.003 & Medium & $\begin{array}{l}\text { Nephrotoxicity, } \\
\text { decreased body } \\
\text { weight }\end{array}$ & Water/IRIS & 1000 \\
\hline Vanadium & 0.007 & Low & Hair & Water/IRIS & 100 \\
\hline
\end{tabular}

NA $=$ not available.

RfD $=$ reference dose. 


\section{Tissue accumulation and clearance}

After absorption by the gastrointestinal tract, arsenic is transported through the blood to most tissues. In humans as well as in most animal species, exposure to either arsenite or arsenate leads to an initial accumulation in the liver, kidneys, and lungs. Although clearance from these tissues is very rapid, long-term arsenic retention is seen in organs rich in proteins containing sulfhydryl groups, such as the hair, skin, squamous epithelium of the upper gastrointestinal tract, epididymis, thyroid, lens, and skeleton (Lindgren et al., 1982). Specific target tissue is dependent on the form of arsenic. Higher retention of arsenic occurs from exposure to trivalent arsenic than to the pentavalent form and tissue distribution varies (Webb, 1966; Casarett and Doull, 1991).

In humans and rats, inorganic arsenic passes through the placental barrier. It is known to enter both cow and human milk (Marcus and Rispin, 1988).

In the human body, where methylcobalamine acts as a major methyl group donor in the biotransformation process, inorganic arsenic converts to methylated compounds. The major site of arsenic methylation is the liver (Marcus and Rispin, 1988). Trivalent arsenic is the substrate for methylation, and pentavalent arsenic must be reduced to trivalent arsenic before methylation can occur. Dimethylarsenic acid is a major metabolite found in animals and humans. Methylation results in a detoxification of inorganic arsenic (about 1 order of magnitude per methyl group) and increases the rate of arsenic excretion from the body.

The kidneys are the major route of excretion following human exposure to inorganic arsenic (Ishinishi et al., 1986). Only a small amount is excreted in feces. The excretion rate in urine varies, depending on the chemical form of arsenic, the duration of exposure, and the species exposed. In humans exposed to a single low dose of arsenite, about 35 percent was excreted in urine over 48 hours (Buchet et al., 1980; 1981). When human intake continues over a few days, 60 to 70 percent of the daily dose is excreted in urine (Buchet et al., 1981). The limited human data available indicate the excretion rate of arsenate is similar to that of arsenite. Other less important routes of elimination of inorganic arsenic include skin, hair, nails, and sweat.

After oral intake of radiolabeled pentavalent arsenic, 66 percent was excreted with a half time of 2.1 days, 30 percent with a half time of 9.5 days, and 3.7 percent with a half time of 38 days (Marcus and Rispin, 1988).

\section{Environmental sources of arsenic}

Arsenic is ubiquitous in nature in both inorganic and organic compounds. Water is the major means of transport of arsenic under natural conditions. In oxygenated water, arsenic occurs in a pentavalent form; under reducing conditions, the trivalent form predominates. Sedimentation of arsenic in 
association with iron and aluminum represents a considerable factor in environmental transport and deposition of this element (Marcus and Rispin, 1988).

As a result of arsenic's widespread occurrence, the general human population is exposed to it primarily from drinking water and foodstuffs. Certain target groups are exposed to arsenic from industrial and agricultural uses. Medicinal use has also been a significant means of human exposure.

Drinking water usually contains a few micrograms of arsenic, predominantly as inorganic salts in the trivalent and pentavalent states (WHO, 1981). The average estimated arsenic intake from drinking water is about $0.005 \mathrm{mg} / \mathrm{kg}$-day. However, concentrations of up to $1.1 \mathrm{mg} / \mathrm{L}$ in drinking water have been reported in Chile, Argentina, Taiwan, the United States, and the United Kingdom (WHO, 1981). Certain foods contain appreciable amounts of arsenic. Arsenic concentrations in fish and seafood, particularly shellfish, are generally 1 or 2 orders of magnitude higher than in other foods. Wine and mineral waters can contain several hundred micrograms of arsenic per liter (Crecelius, 1977; WHO, 1981).

\section{Toxicity of arsenic}

Exposure levels associated with acute arsenic toxicity vary with the valency form of the element. Trivalent arsenicals (arsenites) generally are more toxic than pentavalent (arsenates) (Morrison et al., 1989) and inorganic arsenic compounds are more toxic than organic (Shannon and Strayer, 1989). Geochemical models for the Bowman UMTRA Project indicate arsenic exists primarily in the pentavalent form in ground water (Table 3.5). The reported estimated acute oral lethal dose of arsenic trioxide in humans ranges from 70 to $300 \mathrm{mg}$ (1 to $4 \mathrm{mg} / \mathrm{kg}$ ) (EPA, 1984). Acute exposure to inorganic arsenic compounds may lead to a severe inflammation of the gastrointestinal tract, encephalopathy, and acute renal failure after ingestion.

Increasing chronic oral ingestion doses of arsenic progressively produce systemic effects including arterial thickening in children and adults $10.02 \mathrm{mg} / \mathrm{kg}$ day); neurological symptoms, including peripheral neuropathy $(0.04 \mathrm{mg} / \mathrm{kg}$-day); fibrosis of the liver $(0.05 \mathrm{mg} / \mathrm{kg}$-day); and cirrhosis of the liver $(0.08 \mathrm{mg} / \mathrm{kg}$-day) (DHHS, 1993).

Chronic arsenic intoxications result from exposure to even small doses of arsenic over a long period of time. These intoxications are frequently caused by arsenic in drinking water and in food. Changes of the skin leading to skin cancer are commonly seen in populations exposed to high arsenic concentrations in drinking water. Endemic arsenic poisoning is seen in Cordoba, Argentina, where the concentration of arsenic in drinking water ranges from 0.9 to $3.4 \mathrm{mg} / \mathrm{L}(0.026$ to $0.097 \mathrm{mg} / \mathrm{kg}$-day). Certain areas in Taiwan also have high natural arsenic concentrations in drinking water that cause blackfoot disease (a peripheral extremity vascular disorder resulting in gangrene). A 
dose-response relationship between the incidence of blackfoot disease and the duration of exposure to arsenic is documented (Tseng, 1977).

Hyperpigmentation, hyperkeratoses, and skin cancer with prevalence of 7.1 percent, 18.4 percent, and 1.1 percent, respectively, were reported in Taiwanese studies of more than 40,000 people exposed to arsenic in drinking water at daily intakes ranging from 1.4 to $6.3 \mathrm{mg}(0.02$ to $0.09 \mathrm{mg} / \mathrm{kg}$-day).

Teratogenic effects of arsenic compounds administered intravenously or intraperitoneally at high doses have been demonstrated in laboratory animals only (Ferm, 1971; Hood, 1972; EPA, 1984). Teratogenic effects, also referred to as birth defects, are defined as effects resulting in structural or functional anomalies in live offspring.

Certain characteristics of exposed human populations may influence arsenic toxicity at high exposure levels. Genetic dispositions (rapid versus poor acetylators) and protein-deficient diet may decrease the methylation of arsenic, increasing arsenic deposition in target organs (e.g., lung or skin).

The EPA classifies inorganic arsenic as a Group A (human) carcinogen (EPA, 1994). This classification is based on the increased lung cancer mortality in populations exposed primarily through inhalation and the increased skin cancers in populations exposed through drinking water containing high arsenic concentrations. The current slope factor for oral exposure to arsenic is given in Section 6.0. The EPA is reviewing this slope factor with respect to recent data that suggest arsenic ingestion may increase cancers in internal organs as well as skin cancers. Figure 5.1 summarizes the potential health effects of exposure to arsenic as a function of intake.

\subsubsection{Selenium}

\section{Absorption}

Although approximately 90 percent of the water-soluble forms of selenium (such as selenite) are absorbed in the gastrointestinal tract in rats, humans show only 40 to 80 percent absorption (Bopp et al., 1982). Absorption by ruminants is only 30 to 35 percent, probably due to bacterial reduction in the rumen. Absorption of the less soluble elemental selenium or selenium sulfide is poor in rats (Medinsky et al., 1981; Cummins and Kimura, 1971).

\section{Tissue accumulation and clearance}

Human studies suggest selenium distribution is similar in humans and laboratory animals (Bopp et al., 1982). At low intake levels, selenium is retained and accumulates in the reproductive organs, brain, and thymus, with only transient accumulation in other organs. Selenite-derived selenium accumulates in the liver and kidneys more rapidly than selenium derived from selenate (Millar 


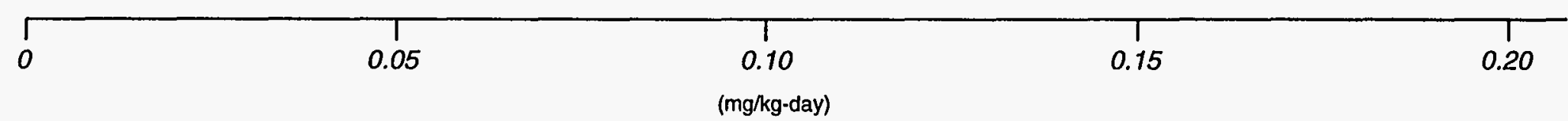

$\sqcup$

BACKGROUND INTAKE LEVELS FROM DRINKING WATER

$\triangle$ ORAL REFERENCE DOSE $=0.0003 \mathrm{mg} / \mathrm{kg}$-day

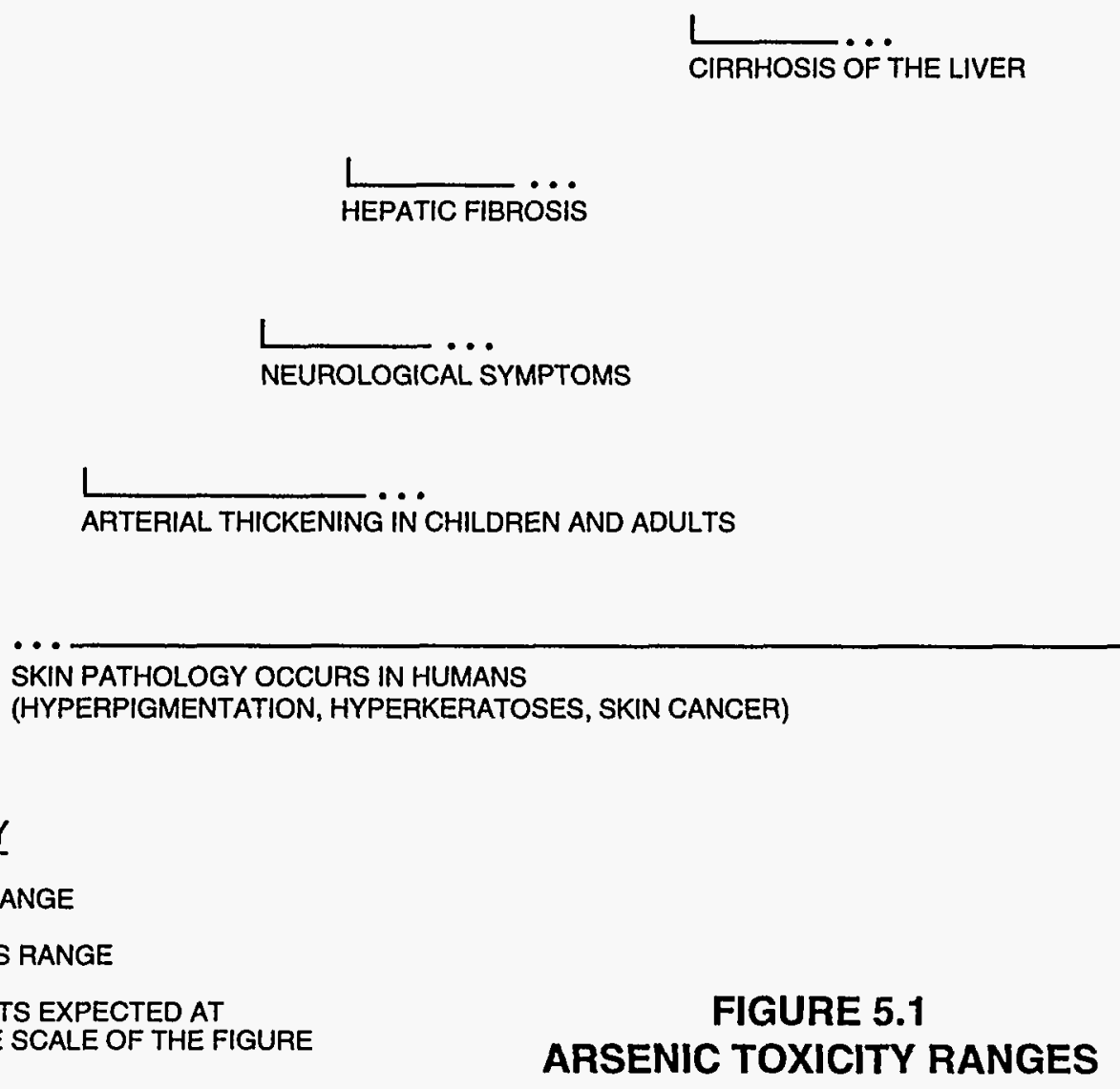


et al., 1973). There is some indication that organically bound forms of selenium exist in a separate, more bioavailable pool than either selenite and selenate.

Although urinary excretion is the primary route of elimination under normal dietary conditions (67 percent), in a deficiency state fecal excretion is the major pathway. At toxic doses, the major excretion route is through expired air as dimethylselenide (50 to 60 percent) (Friberg et al., 1986). Although these data were obtained from rats, other data suggest human excretion patterns are similar (Bopp et al., 1982). Selenium elimination in humans follows three phases with the following half times: 1,8 to 20 , and 65 to 116 days.

\section{Environmental sources of selenium}

The main source of selenium for the general population is food (e.g., seafood, meat, and grains). Dietary intake of selenium in the United States ranges from 0.0007 to $0.0029 \mathrm{mg} / \mathrm{kg}$-day. Selenium concentrations in ground water and surface water range from 0.00006 to $0.400 \mathrm{mg} / \mathrm{L}$, with highs of $6 \mathrm{mg} / \mathrm{L}$ reported (Friberg et al., 1986). Public water supplies in the United States rarely exceed $0.010 \mathrm{mg} / \mathrm{L}$ (EPA, 1980). High selenium concentrations occur in volcanic rock [0.120 milligrams per gram] and in sandstone uranium deposits (1 $\mathrm{mg}$ per gram). The soil content of selenium varies widely, as does the rate of accumulation by plants. Although grasses and grains do not accumulate selenium in concentrations greater than $50 \mathrm{mg} / \mathrm{kg}$, some plants grown in high-selenium regions can accumulate as much as $10,000 \mathrm{mg} / \mathrm{kg}$. These high-accumulating plants generally are not used as food sources, but can produce toxic effects when they are consumed by livestock.

\section{Toxicity of selenium}

Ingestion of 350 to $4300 \mathrm{mg}$ of selenium by adults produces vomiting, diarrhea, abdominal cramps, numbness in arms, marked hair loss, and irregular menstrual bleeding in women. Higher intakes can result in unsteady gait, cyanosis of mucous membranes, labored breathing, and sometimes death.

Selenium is an essential nutrient. The adult RDA is 0.0006 to $0.0011 \mathrm{mg} / \mathrm{kg}$-day. Although some biochemical alterations, including prolonged prothrombin time and reduced blood glutathione concentrations, are observed with selenium intakes from 0.0107 to $0.0121 \mathrm{mg} / \mathrm{kg}$-day, clinical signs of selenosis are not observed at these levels. Mild toxicity, including hair loss or breakage, nail thickening and brittleness, and a garlic odor in dermal excretions and breath, were reported in human populations with selenium dietary intakes of $0.015 \mathrm{mg} / \mathrm{kg}$-day. However, selenium intake as high as $0.013 \mathrm{mg} / \mathrm{kg}$-day can produce symptoms of selenosis such as hair and nail loss in susceptible populations.

Persistent clinical symptoms of selenosis are caused by the chronic dietary intake of selenium by human populations living in areas of China where selenium concentrations in the soil range from 7 to $12 \mathrm{mg} / \mathrm{kg}$. The estimated selenium 
dietary intake was 0.018 and $0.021 \mathrm{mg} / \mathrm{kg}$-day, respectively, for adult women and men (Yang et al., 1989a; 1989b). The average blood selenium concentration associated with this selenium intake was $1.3 \mathrm{mg} / \mathrm{L}$ (ranging from 1.05 to $1.85 \mathrm{mg} / \mathrm{L}$ ). Symptoms of chronic selenosis with hair and nail loss and below-normal hemoglobin levels were reported in the same study at selenium intakes of $0.071 \mathrm{mg} / \mathrm{kg}$-day. A serious outbreak of selenium poisoning, including the possible occurrence of neurotoxic effects such as peripheral anesthesia, acroparesthesia, and pain in the extremities, was observed with selenium intake of $0.54 \mathrm{mg} / \mathrm{kg}$-day in both women and men. It is important to note that the protein intake of this population is unknown. Figure $\mathbf{5 . 2}$ summarizes the health effects from exposure to selenium as a function of intake.

Symptoms of alkali disease and blind staggers are reported in livestock grazing long-term on selenium-accumulating plants in areas with high soil selenium levels (Rosenfeld and Beath, 1964). These symptoms include neurological dysfunction such as impaired vision, ataxia, and disorientation, and respiratory distress.

\subsubsection{Sodium}

\section{Absorption}

Sodium is rapidly and fully absorbed from the intestinal tract. The skin and lungs also absorb sodium rapidly, by simple diffusion and ion exchange. Sodium travels in the blood, where it ultimately passes through the kidneys. After the kidneys filter all the sodium out, the adrenal hormone aldosterone maintains sodium concentration in the bloodstream at the amount needed (National Research Council, 1980).

\section{Tissue accumulation and clearance}

Sodium is the major extracellular ion, essential to regulating the acid-base balance and an important contributor to extracellular osmolarity. It is an essential constituent in the electrophysiological functioning of cells and is required for impulse propagation in excitable tissues. Furthermore, sodium is essential for active nutrient transport, including the active transport of glucose across the intestinal mucosa. About 30 to 40 percent of the body's sodium is thought to be stored on the surfaces of the bone crystals, where it is easy to recover if the blood sodium level drops.

Sodium excretion is mainly urinary, with appreciable amounts also excreted in feces, sweat, and tears (Venugopal and Luckey, 1978). Mammalian renal sodium excretion is a two-phase process involving glomerular filtration and reabsorption in proximal tubules; of about 600 grams of sodium involved in 24hour glomerular filtration, approximately 99.5 percent is reabsorbed in human adults. A homeostatic mechanism for sodium functions at the renal excretory level. 


\begin{tabular}{llll|llll|l}
\hline 0 & 0.0025 & 0.005 & 0.0075 & $\begin{array}{c}0.01 \\
\text { (mg/kg-day) }\end{array}$ & 0.0125 & 0.015 & 0.0175 & 0.020
\end{tabular}

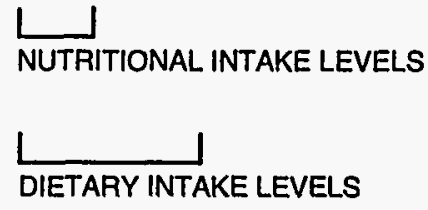

$\triangle$ ORAL REFERENCE DOSE (0.005 mg/kg-day)
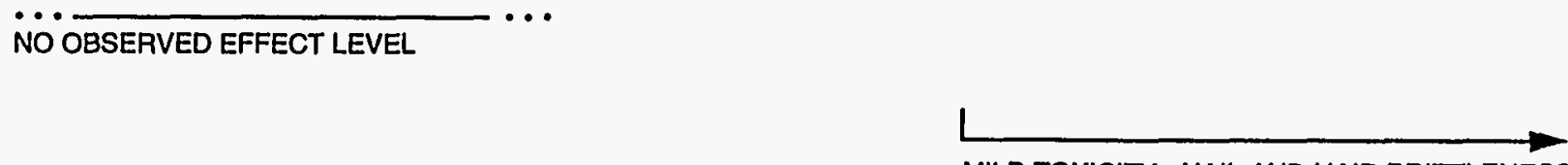

MILD TOXICITY - NAIL AND HAIR BRITTLENESSILOSS

... UNCERTAINTY RANGE

KNOWN IMPACTS RANGE

TOXICITY IMPACTS EXPECTED AT

LEVELS OFF THE SCALE OF THE FIGURE 


\section{Environmental sources of sodium}

Total sodium intake is influenced mainly by the extent to which salt (sodium chloride) is added to food, the inherent salt content of the foods consumed, and the intake of other sodium salts in the diet and medication. Sodium is a natural constituent of both vegetable and animal products in varying concentrations. Other sources of sodium are medications, drinking water, cooking water, soft drinks, and alcoholic beverages.

At 2 months, infants consume approximately $300 \mathrm{mg}$ of sodium a day; at 12 months, approximately $1400 \mathrm{mg}$ a day. Human milk contains $161 \mathrm{mg} / \mathrm{L}$ and cow's milk contains approximately $483 \mathrm{mg} / \mathrm{L}$ (Carson et al., 1986).

No RDA has been set for sodium. The National Research Council advises

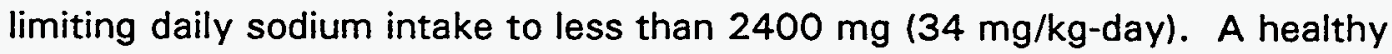
person requires about $115 \mathrm{mg}$ sodium daily $(1.6 \mathrm{mg} / \mathrm{kg}$-day), yet sodium dietary intake is estimated at 57 to $85 \mathrm{mg} / \mathrm{kg}$-day. However, dietary sodium intake levels as high as $134 \mathrm{mg} / \mathrm{kg}$-day are reported (National Research Council, 1980). The American Heart Association recommends limiting sodium intake to $3000 \mathrm{mg}$ daily (43 $\mathrm{mg} / \mathrm{kg}$-day).

The sodium content of drinking water is extremely variable. A survey by the Interstate Carrier Water Supply Systems indicates sodium concentrations in 630 systems ranged from less than 1 to $402 \mathrm{mg} / \mathrm{L}$ (resulting in drinking water ingestion rates from less than 0.03 to $11 \mathrm{mg} / \mathrm{kg}$-day), with 42 percent greater than $20 \mathrm{mg} / \mathrm{L}$ and 3 percent over $200 \mathrm{mg} / \mathrm{L}$ (Carson et al., 1986).

\section{Toxicity of sodium}

Acute toxicity symptoms from sodium chloride in healthy adult males accompanied by visible edema may occur with an intake as low as 35 to 40 grams of salt (sodium chloride) per day $(20$ to $23 \mathrm{mg} / \mathrm{kg}$-day because sodium is 39 percent of the weight of sodium chloride) (Meneely and Battarbee, 1976). The mean lethal sodium dose for humans is $3230 \mathrm{mg} / \mathrm{kg}$ (Venugopal and Luckey, 1978).

Epidemiological studies indicate long-term excessive sodium intake is one of many factors associated with hypertension in humans. A high sodium/ potassium ratio in the diet may be detrimental to persons susceptible to high blood pressure. Some adults, however, tolerate chronic intake above 40 grams of sodium chloride per day (23 mg/kg-day) (Carson et al., 1986).

Research shows critical levels of sodium ingestion can increase blood pressure (with age) and cause hypertension in some people. Freis (1976) reports that with sodium intake below $227 \mathrm{mg} / \mathrm{day}(3 \mathrm{mg} / \mathrm{kg}$-day for a 70-kg adult), hypertension is absent. In the range of 227 to $1591 \mathrm{mg}$ per day ( 3 to $23 \mathrm{mg} / \mathrm{kg}$-day for a 70-kg adult), a few cases of hypertension may occur, while in the range of 1590 to $8000 \mathrm{mg}$ per day $(23$ to $114 \mathrm{mg} / \mathrm{kg}$-day for a $70-\mathrm{kg}$ 
adult), approximately 15 percent of exposed adults will exhibit hypertension. When sodium intake rises above $8000 \mathrm{mg}$ per day, hypertension may occur in about 30 percent of the population.

Because sodium chloride is present in nearly all processed and packaged foods, it is difficult to limit dietary sodium intake. Average daily dietary intakes in the United States are often within the range of hypertensive effects. Sodium levels in drinking water generally do not contribute significantly to the total intake unless sodium is at higher than average levels in the water supply. However, people on sodium-restricted diets can obtain a significant portion of daily sodium from drinking water. Because the kidneys are the major organs involved in regulating sodium balance, individuals with compromised kidney function may be placed on a low-sodium diet. In addition, other individuals may be on lowsodium diets to control hypertension. Because of the high prevalence of such individuals in our society, the American Heart Association proposes that public drinking water supplies in the United States adopt a standard of $20 \mathrm{mg} / \mathrm{L}$ sodium (Calabrese and Tuthill, 1977). This level would limit the additional intake of sodium from drinking water to approximately $0.6 \mathrm{mg} / \mathrm{kg}$-day for a $70-\mathrm{kg}$ adult. Figure 5.3 summarizes the potential sodium health effects as a function of intake.

\subsubsection{Sulfate}

\section{Absorption}

Sulfate absorption from the gastrointestinal tract is similar in humans and other animals. Generally, more than 90-percent absorption is reported for sulfate doses below $150 \mathrm{mg} / \mathrm{kg}$, decreasing to 50 to 75 percent as the dose increases into the grams-per-kilogram range.

\section{Tissue accumulation and retention}

Ingesting high levels of sulfate results in transient increases in both blood and urine concentrations. Approximately 50 percent of a $75-\mathrm{mg} / \mathrm{kg}$ sulfate dose is excreted over 72 hours. The urinary excretion mechanism is transport-limited and therefore can become saturated at high doses of sulfate. Excess sulfate also is excreted in feces in its inorganic form. Available data do not indicate sulfate accumulates, even with chronic ingestion of above-normal levels. However, extremely high chronic doses apparently have not been examined in humans.

Sulfate is used to biosynthesize collagen, cartilage, and dentin and to form sulfate esters of both endogenous compounds (such as lipids and steroids) and exogenous compounds (such as phenols). Sulfation is important in detoxication pathways because it increases the solubility of these compounds, which enhances their excretion in the urine. Exposure to high concentrations of compounds that are conjugated with sulfate and excreted can produce a transient decrease in sulfate concentrations in plasma. 


\begin{tabular}{|c|c|c|c|c|c|c|c|c|c|c|}
\hline & $T$ & $\mathrm{~T}$ & $T$ & $T$ & $T$ & $T$ & $T$ & $T$ & $T$ & $T$ \\
\hline 0 & 10 & 20 & 30 & 40 & 50 & 60 & 70 & 80 & 90 & 100 \\
\hline
\end{tabular}

L

BACKGROUND INTAKE LEVELS FROM DRINKING WATER

A NUTRITIONAL REQUiREMENT

... UNCERTAINTY RANGE

\section{KNOWN IMPACTS RANGE}




\section{Environmental sources of sulfate}

Drinking water in the western United States in 1978 showed sulfate concentrations range from 0 to $820 \mathrm{mg} / \mathrm{L}$, with a mean concentration of $99 \mathrm{mg} / \mathrm{L}$. The EPA estimates normal sulfate intake ranges from 0.00023 to $0.0064 \mathrm{mg} / \mathrm{kg}$-day from air and 0.000 to $2.9 \mathrm{mg} / \mathrm{kg}$-day from drinking water. These estimates are based on the concentration range found in western United States water supplies. No estimates are available on sulfate intake from food sources.

\section{Toxicity of sulfate}

The acute and chronic effects of sulfate toxicity differ more in severity than in symptoms or mechanisms. Therefore, this discussion combines acute and chronic toxicities. Data do not indicate a sulfate bioaccumulation with chronic exposure. Sulfate salts of magnesium and sodium are used medicinally as cathartics. High concentrations of unabsorbed sulfate salts in the gut can pull large amounts of water into the gut, greatly increasing the normal volume of feces. This reaction is the basis of the toxic effects.

Toxicity in humans primarily manifests in diarrhea; the severity of the diarrhea is dose-dependent. Chronic sulfate ingestion can result in persistent diarrhea, leading to ionic imbalances and dehydration similar to that seen with extremely high acute doses. When drinking water is contaminated with sulfate, the taste of the water may make it unpalatable and reduce consumption. This lower water intake could compound the dehydration effects of the diarrhea. Extreme dehydration can lead to death. As with nitrate toxicity, infants seem to be the most susceptible population for sulfate-induced diarrhea.

In cattle, high sulfate intake results in sulfhemoglobinemia, a condition similar to the methemoglobinemia induced by nitrate ingestion. Sulfhemoglobinemia has not been reported following sulfate ingestion by humans, although the condition does occur in humans following inhalation of hydrogen sulfide.

Sulfate toxicity data are based primarily on epidemiologic studies of human adults and infants who report to hospitals with symptoms of sulfate exposure. Most exposure doses were back-calculated by sampling their drinking water. Therefore, these data do not represent well-controlled studies with readily defined dose ranges. Figure 5.4 summarizes the health effects from exposure to sulfate as a function of intake.

\subsubsection{Molybdenum}

\section{Absorption}

Molybdenum absorption in the gastrointestinal tract depends on the species. Both inorganic and hexavalent forms such as molybdenum trioxide, sodium molybdate, and ammonium molybdate are readily absorbed from both food and 


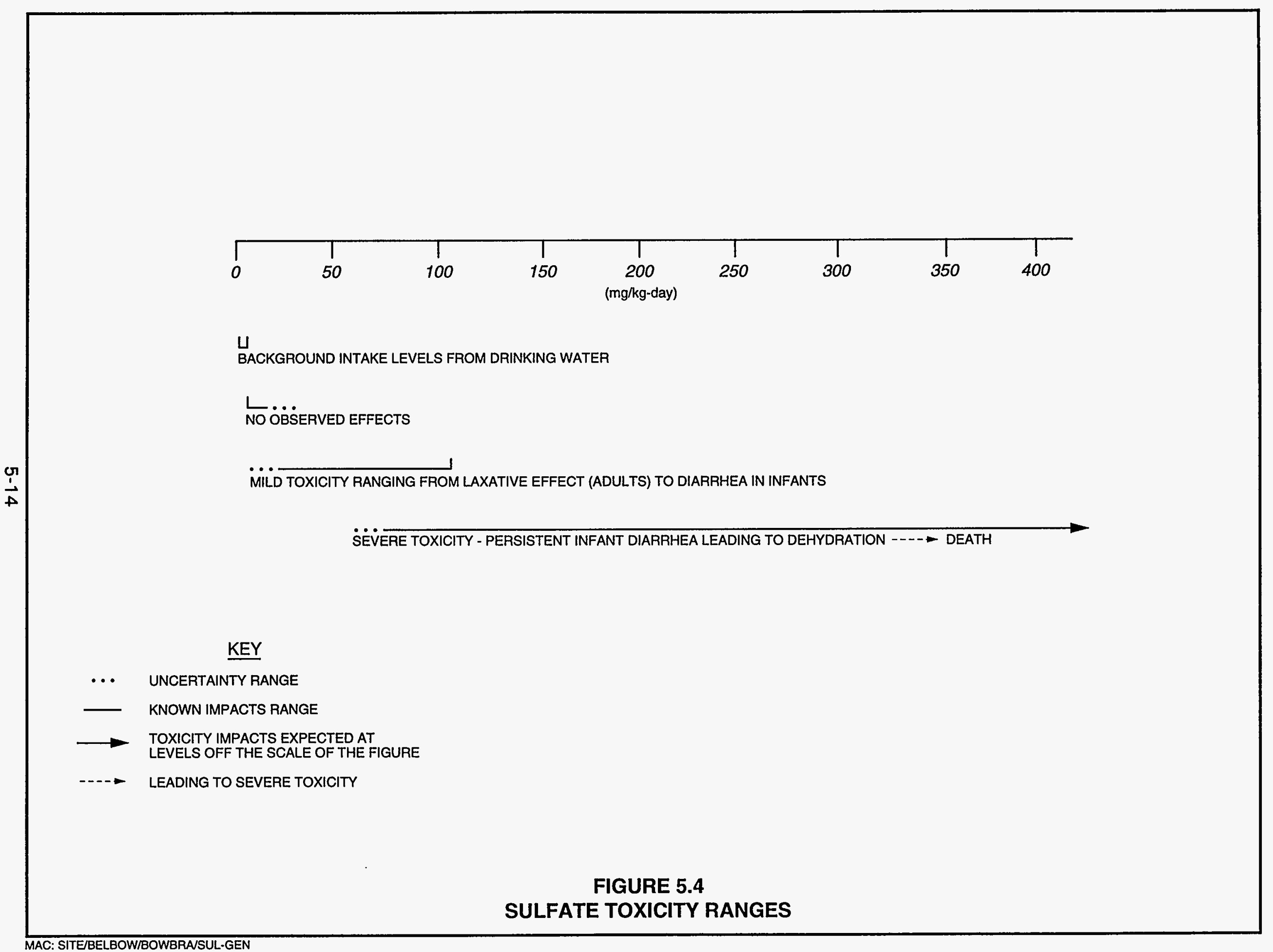


water, whereas molybdenite is not. Human absorption rates of 40 to 70 percent have been observed (Tipton et al., 1969; Robinson et al., 1973; Alexander et al., 1974).

\section{Tissue accumulation and clearance}

In humans, the highest concentrations of molybdenum occur in the liver, kidney, and adrenals (Casarett and Doull, 1991). With normal dietary intake, molybdenum levels in the body slowly increase until approximately age 20 and then begin to decline steadily. Urine is the principal excretion route in humans. Human studies indicate the biological half-life in humans is considerably longer than in animals and may be as long as 2 weeks (Rosoff and Spencer, 1964).

\section{Environmental sources of molybdenum}

Natural molybdenum occurs in combination with other metals, including uranium, lead, iron, cobalt, and calcium. Native soil concentrations can vary by as much as 2 orders of magnitude, from 0.1 to $10 \mathrm{mg} / \mathrm{kg}$, leading to large variations in molybdenum concentrations in plant materials. Natural concentrations in ground water have been reported from 0.00011 to $0.0062 \mathrm{mg} / \mathrm{L}$. The estimated human dietary intake of molybdenum is 0.05 to $0.24 \mathrm{mg}$ per day $(0.0007$ to $0.003 \mathrm{mg} / \mathrm{kg}$-day). The estimated contribution of drinking water ranges from 0 to 95 percent. The nutritional intake for molybdenum ranges from 0.0015 to $0.0054 \mathrm{mg} / \mathrm{kg}$-day. Molybdenum is an essential trace element that functions as a necessary constituent of several enzymes, including xanthine oxidase (which is involved in the metabolism of uric acid) and nitrate reductase (Friberg et al., 1986). Symptoms of molybdenum deficiency have not been reported in humans.

\section{Toxicity of molybdenum}

Acute toxic effects have not been reported for molybdenum. No adverse health effects have been reported with chronic molybdenum intake of less than $0.008 \mathrm{mg} / \mathrm{kg}$-day. The primary toxicity of molybdenum is related to its interactions with copper and sulfur, leading to altered excretion patterns for these elements. Increased molybdenum levels increase the levels of xanthine oxidase, which is responsible for the production of uric acid. High levels of uric acid can accumulate in joints and lead to symptoms of gout and other joint disorders.

Molybdenum intake of 0.008 to $0.022 \mathrm{mg} / \mathrm{kg}$-day can produce mineral imbalance as a result of increased copper excretion. Copper excretion has been reported to double with molybdenum intakes at the upper end of this range. Copper is an essential nutrient important in many metabolic pathways, including the synthesis and function of hemoglobin. A copper deficiency resulting from excess excretion will impair the oxygen-carrying capacity of the blood, and severe copper deficiencies can lead to hypochromic microcytic anemia. Gout-like symptoms and joint deformities were reported in humans in regions of 
Russia where elevated molybdenum concentrations in soil and subsequent increased molybdenum concentrations in food led to molybdenum intakes ranging from 0.14 to $0.21 \mathrm{mg} / \mathrm{kg}$-day. Figure 5.5 summarizes these health effects as a function of intake.

\subsubsection{Uranium}

Naturally occurring uranium present at UMTRA Project sites consists of three radioactive isotopes: uranium-234, uranium-235, and uranium-238. More than 99 percent of natural uranium occurs as uranium-238 (Cothern and Lappenbusch, 1983). Uranium-238 undergoes radioactive decay by emitting alpha particles to form uranium-234, thorium-230, radium-226, radon-222, polonium-210, and other radioisotopes. Figure 5.6 summarizes the radioactive decay chain of uranium-238 and uranium-234. As all uranium isotopes in nature are radioactive, the hazards of high uranium intake are its chemical toxicity and potential radiological damage. The chemical toxicity of natural uranium is discussed below. Carcinogenic potential associated with exposure to radioactive isotopes of natural uranium is discussed in Section 5.3.

\section{Absorption}

Uranium absorption in the gastrointestinal tract depends on the solubility of the uranium compounds. The hexavalent uranium compounds, especially the uranyl salts, are water soluble, while tetravalent compounds generally are not (Weigel, 1983). Even with soluble compounds, however, only a small fraction is absorbed. Wrenn et al. (1985) report human gastrointestinal absorption rates of 0.76 to 7.8 percent.

\section{Tissue accumulation and clearance}

In humans exposed to background levels of uranium, the highest concentrations were found in bone, muscle, lung, liver, and kidney (Fisenne et al., 1988). Uranium in bone has a short retention half time of 20 days followed by a long retention half time of 5000 days (Tracy et al., 1992).

In body fluids, uranium tends to convert into water-soluble hexavalent uranium (Berlin and Rudell, 1986). Approximately 60 percent of the uranium in plasma complexes with low-molecular-weight anions (e.g., bicarbonates, citrates), while the remaining 40 percent binds to the plasma protein transferrin (Stevens et al., 1980). Following oral exposure in humans, more than 90 percent of the uranium not already absorbed from the gastrointestinal tract is excreted in the feces. Animal studies indicate that, of the small percent absorbed (typically less than 5 percent), approximately 60 percent is excreted in the urine within 24 hours and 98 percent is excreted within 7 days (Ballou et al., 1986; Leach et al., 1984; Sullivan et al., 1986). A small portion of the absorbed uranium is retained for a longer period. 


\begin{tabular}{|c|c|c|c|c|c|c|c|c|}
\hline & 1 & T & T & 1 & 1 & 1 & T & \\
\hline 0 & 0.0012 & 0.0025 & 0.0037 & 0.005 & 0.0062 & 0.0075 & 0.0087 & 0.01 \\
\hline
\end{tabular}

DIETARY INTAKE LEVELS

A ORAL ReferenCE DOSE (0.005 mg/kg-day)

…...

NO OBSERVED EFFECT LEVEL

MILD TOXICITY - INCREASED COPPER EXCRETION AND URIC ACID SYNTHESIS -..- GOUT

(0.14-0.21 mg/kg-day)

KEY

... UNCERTAINTY RANGE

KNOWN IMPACTS RANGE

$\longrightarrow$ TOXICITY IMPACTS EXPECTED AT

LEVELS OFF THE SCALE OF THE FIGURE

-..- LEADING TO SEVERE TOXICITY 


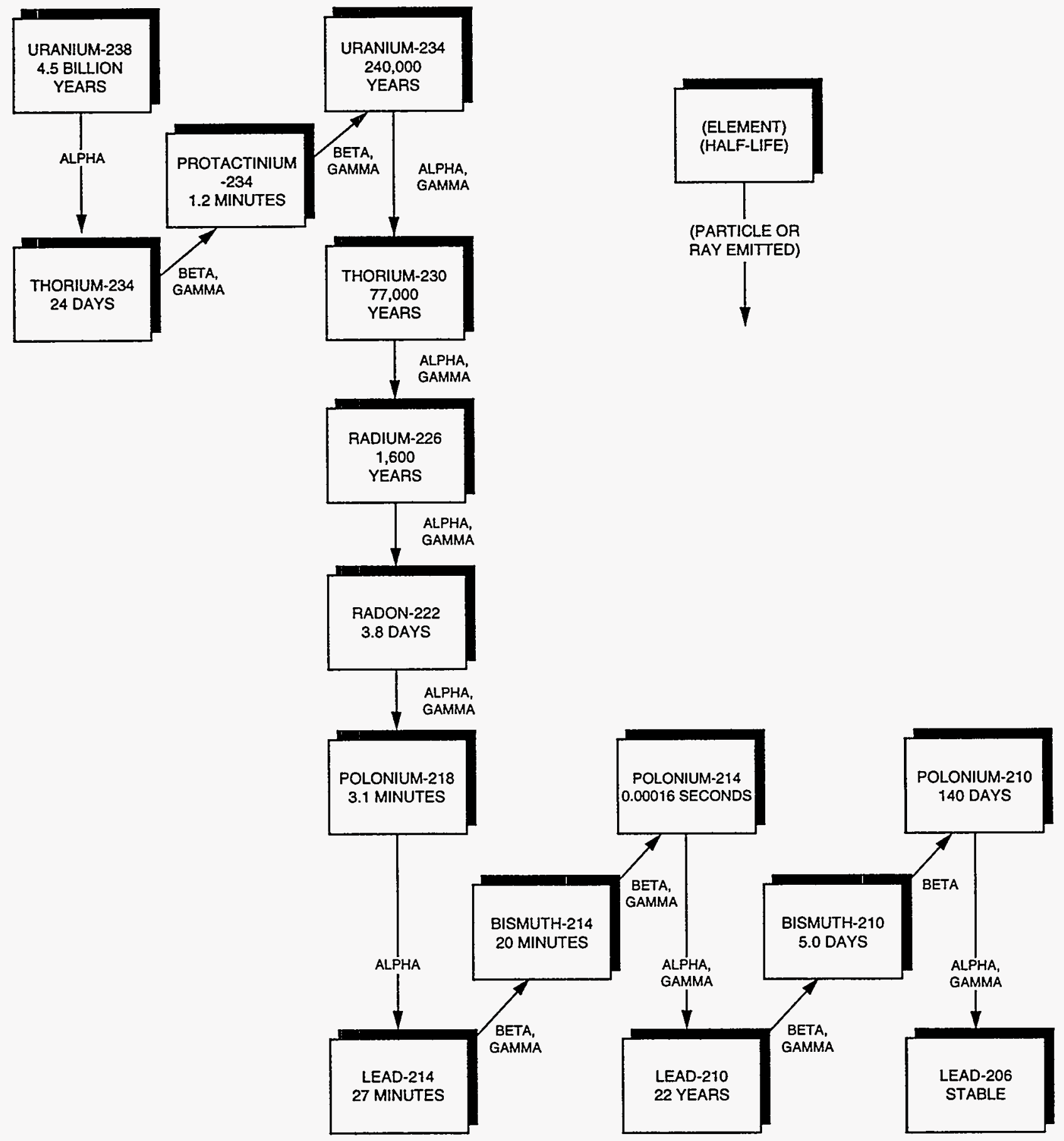

FIGURE 5.6

HALF-LIVES AND EMISSIONS FROM DECAY CHAIN OF URANIUM-238 


\section{Environmental sources of uranium}

Uranium is a ubiquitous element, present in the earth's crust at approximately 4 parts per million ( $\mathrm{ppm}$ ). Uranium concentrations in ground water and surface water averaged $1 \mathrm{pCi} / \mathrm{L}$ and $3 \mathrm{pCi} / \mathrm{L}$, respectively (NCRP, 1984). The amount of uranium plant tissues absorb from the soil depends on the plant species and the depth of the root system (Berlin and Rudell, 1986). Uranium concentrations in plants averaged $0.075 \mu \mathrm{g} / \mathrm{kg}$ of fresh plant material (Tracy et al., 1983).

The main source of uranium for the general population is food (e.g., potatoes, bakery products, meat, and fresh fish) which may contain uranium concentrations between 10 and $100 \mu \mathrm{g} / \mathrm{kg}$ (Prister, 1969). The total dietary intake of uranium from the consumption of average foods is approximately $1 \mu \mathrm{g}$ per day. Cereals and vegetables, particularly root crops, probably contribute most to the daily intake of uranium (Berlin and Rudell, 1986).

\section{Toxicity of uranium}

Exposing the general public to natural uranium probably will not pose an immediate lethal threat to humans. No human deaths definitely attributable to uranium exposure have been reported. The lethal dose for animals ranges from 8 to $242 \mathrm{mg} / \mathrm{kg}$, depending on the solubility of the uranium compound tested (higher solubility compounds have greater toxicity) and the animal species. High doses of uranium cause complete kidney and respiratory failure.

No chronic toxic effects are reported in humans following oral exposure to uranium. Data for populations occupationally exposed to high concentrations of uranium compounds through inhalation and information from studies on experimental animals indicate the critical organ for chronic uranium toxicity is the proximal tubule of the kidney (Friberg et al., 1986). In humans, chemical injury reveals itself by increased catalase excretion in urine and proteinuria. The lowest dose of uranyl nitrate that caused moderate renal damage was given to rabbits in diet at $2.8 \mathrm{mg} / \mathrm{kg}$-day (Maynard and Hodge, 1949). Dose-response data for the toxic effects of uranium are limited; Figure 5.7 summarizes available information.

\subsubsection{Vanadium}

\section{Absorption}

Absorption of vanadium from the gastrointestinal tract is low. The International Commission on Radiological Protection estimate for the absorption of soluble vanadium compounds is 2 percent (ICRP, 1960), but the World Health Organization states that absorption of even very soluble forms of vanadium is less than 1 percent from the gastrointestinal tract (WHO, 1988). Limited human data (from three individuals) suggest as much as 10 percent of a repeated oral dose may be absorbed (Proescher et al., 1917; Tipton et al., 1969). Soluble vanadium compounds that are inhaled and deposited are more readily absorbed 


\begin{tabular}{ll|l|l|l|l|l|l|l|l}
\hline 0 & 1 & 1 & 1 & 1 & 1 & 1 & & \\
& 1 & 2 & 3 & 4 & 5 & 6 & 7 & 8 \\
(mg/kg-day) & & & & &
\end{tabular}

1

DIETARY INTAKE

$\triangle$ ORAL ReferenCE DOSE $(0.003 \mathrm{mg} / \mathrm{kg}$-day $)$

REVERSIBLE KIDNEY IMPAIRMENT AFTER ACUTE HUMAN EXPOSURE (BASED ON DOSE RECONSTRUCTION, CASE STUDY)

- $\quad$ No OBSERVED EFFECTS IN EITHER MICE OR RATS (SUFFICIENT HUMAN DATA NOT AVAILABLE)

\section{L.}

MILD TOXICITY

KEY

(RABBITS, RENAL DAMAGE)

... UNCERTAINTY RANGE

- KNOWN IMPACTS RANGE

- - animal study data

TOXICITY IMPACTS EXPECTED AT

LEVELS OFF THE SCALE OF THE FIGURE

FIGURE 5.7

URANIUM TOXICITY RANGES 
(about 25 percent) (WHO 1988). Although soluble forms of vanadium may be absorbed through the skin, absorption through the skin is probably minimal (EPA, 1977; WHO, 1988).

\section{Tissue accumulation and clearance}

Vanadium is found in all body tissues in concentrations ranging from $0.08 \mu \mathrm{g}$ per gram wet weight in spleen tissue to $0.14 \mu \mathrm{g} / \mathrm{g}$ in brain and heart tissue and $0.33 \mu \mathrm{g}$ per gram in aortic tissue (Yakawa and Suzuki-Yasumoto, 1980). Vanadium concentrations in human blood serum are reported to be 0.016 to 0.939 nanogram $(\mathrm{ng}) / \mathrm{mL}$. Vanadium concentrations in hair range from 20 to $60 \mathrm{ng}$ per gram, with higher values found in manic-depressive patients than in normal control groups ( 57 versus $29 \mathrm{ng}$ per gram).

Vanadium distribution in humans following oral exposure may be extrapolated from animal studies. In acute-duration exposures, vanadium is rapidly distributed, primarily in the bones. After intermediate-duration exposure, vanadium concentrations reaching the tissues are low, with the kidneys, bones, liver, and lungs initially showing the highest levels.

Vanadium is an element and is not metabolized. However, in the body, interconversion occurs between vanadyl and vanadate. Vanadium can reversibly bind to the protein transferrin in the blood and then be taken up into erythrocytes. Vanadate is taken into erythrocytes faster than vanadyl, possibly due to the time required for the vanadyl form to be oxidized to vanadate. Initially, vanadyl leaves the blood more rapidly than vanadate, possibly because of the slower vanadyl uptake into cells (Harris et al., 1984). Five hours after administration, blood clearance is essentially identical for the two forms. Vanadate is the dominant vanadium species present in ground water.

Because vanadium is poorly absorbed in the gastrointestinal tract, a large percentage of vanadium in rats is excreted unabsorbed in the feces following oral exposure. In rats, the principal route of excretion of the small absorbed portion of vanadium is through the kidneys. The mean urinary output per 24 hours is $10 \mu \mathrm{g}$.

\section{Environmental sources of vanadium}

Elemental vanadium does not occur in nature but its compounds exist in more than $\mathbf{5 0}$ different mineral ores and in association with fossil fuels. Vanadium is released to the atmosphere mainly through the combustion of fossil fuels, particularly residual fuel oils. Vanadium is released to soil and water mainly through the natural weathering of geological formations (Byerrum et al., 1974; Van Zinderen Bakker and Jaworski, 1980).

Food constitutes the major source of exposure to vanadium for the general population (Lagerkvist et al., 1986). For the population as a whole, dietary intake is estimated to be 6 to $18 \mu \mathrm{g}$ per day (Pennington and Jones, 1987), 
although other estimates from older studies using different and possibly less sensitive analytical methods have been as high as $2 \mathrm{mg}$ per day (Schroeder et al., 1963).

Drinking water is not considered an important source of vanadium exposure for the general population. Values for 92 percent of the water samples taken from across the United States were below $10 \mu \mathrm{g} / \mathrm{L}$. Typical values appear to be around $1 \mu \mathrm{g} / \mathrm{L}$ (Lagerkvist et al., 1986). The estimated daily intake of vanadium by the inhalation route is $1 \mu \mathrm{g}$ (Byrne and Kosta, 1978).

Although vanadium is considered an essential element for chickens and rats, there is no certainty about human dietary requirements. For animals, the daily requirement is about 10 to $25 \mu \mathrm{g} /$ day (Pennington and Jones, 1987).

\section{Toxicity of vanadium}

The major adverse health effect to humans from vanadium is seen in workers exposed to large amounts of vanadium pentoxide dusts. The probable oral lethal dose of vanadium pentoxide for humans is between 5 and $50 \mathrm{mg} / \mathrm{kg}$ (Gosselin et al., 1976).

Systemic effects of vanadium exposure have been observed in the liver, kidneys, nervous and cardiovascular systems, and blood-forming organs. Metabolic effects include interference with the biosynthesis of cystine and cholesterol, depression and stimulation of phospholipid synthesis, and at higher concentrations, inhibition of serotonin oxidation. Other effects of vanadium on mammalian metabolism include depression of phospholipid synthesis (Snyder and Cornatzer, 1958), reduction of coenzyme $Q$ levels in mitochondria (Aiyar and Sreenivasan, 1961), and stimulation of monoamine oxidase, which oxidizes serotonin (Perry et al., 1955).

Vanadium salts were given to patients in several studies to reduce cholesterol levels (Curran et al., 1959; Somerville and Davies, 1962; Dimond et al., 1963; Schroeder et al., 1963). The doses of vanadium in these studies varied from 7 to $30 \mathrm{mg}$ per day $(0.1$ to $0.4 \mathrm{mg} / \mathrm{kg}$-day). Transient decreases in serum cholesterol levels were observed in some patients, as were loosened stool and cramps. Green tongue, a hallmark of vanadium exposure, was observed in all patients.

Tank and Storvick (1960) report a relationship between the concentration of vanadium in drinking water and the incidence of dental caries in children. Dental caries incidence in children aged 7 to 11 years was reduced three times (compared to controls) by applying ammonium vanadate in glycerol to the teeth (Belehova, 1969). This relationship was not found in other studies (Hadjimarkos, 1966; 1968).

It has been suggested that raised tissue levels of vanadium are important in the etiology of manic-depressive illness. Improvement after treatment with ascorbic 
acid or reduced vanadium intake was seen both in manic and depressed patients.

Although animal studies report impaired conditioned reflexes following doses of vanadium from 0.05 ( 6 months) to 0.5 (21 days) $\mathrm{mg} / \mathrm{kg}$-day, effects on the nervous system were not observed following repeated oral administration of vanadium to humans. Workers exposed by inhalation to "fairly high" concentrations of vanadium compounds $\left(\mathrm{mg} / \mathrm{m}^{3}\right)$ reported nonspecific symptoms such as headache, weakness, vomiting, nausea, and ringing of the ears (WHO, 1988).

Data on vanadium toxicity are insufficient to evaluate its effect on cholesterol levels, iron metabolism, blood-cell production, and mutagenesis. However, due to poor absorption from the gut, the metal is not considered very toxic following oral administration (WHO, 1988). Figure 5.8 summarizes the vanadium toxicity based on dose-response.

\subsection{CONTAMINANT INTERACTIONS}

Some information is available on potential interactions between contaminants found at UMTRA Project sites. However, discussions of potential interactions generally can be presented only qualitatively. In addition to physiological variables between individuals that can affect toxicity, uncertainties in interactions also result from 1) differences in the relative exposure concentrations of the different contaminants compared to the concentrations tested experimentally, and 2) additional ground water constituents that may be present in sufficient quantities to modify predicted toxicities even though they themselves are not considered contaminants of potential concern for human health. Therefore, the interactions described below should be recognized as factors that can influence predicted toxicities, although the precise nature and magnitude of that influence cannot be determined.

The potential for interactions between metals is of primary concern at UMTRA Project sites. Interactions between several similar metals can alter the predicted absorption, distribution in the body, metabolism, toxicity, or clearance of a metal of interest. At the Bowman site, interaction is possible not only between metals attributable to site activities but also between metals occurring naturally in background ground water. Metal constituents occurring in background ground water at levels of concern for chemical interactions are the constituents above the available health advisory levels and/or EPA MCLs. Metal constituents not elevated above background on the site but found in background at levels above health advisories and/or EPA MCLs are antimony, cadmium, and lead. Although water quality data for several of these constituents vary with the most recent sampling rounds and show no detections, their presence and potential interactions with other metals are possible.

Nitrate-sulfate interactions could occur at the Bowman site. No clear data are available to assess the magnitude of this interaction, but the epidemiological 


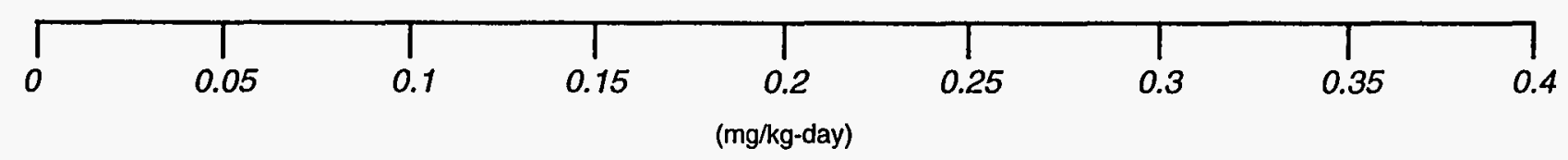

| DIETARY INTAKE

A ORAL REFERENCE DOSE (HEAST) - DRINKING WATER $(0.007 \mathrm{mg} / \mathrm{kg}$-day)

TRANSIENT CHOLESTEROL DROP, CRAMPS, GREEN TONGUE (0.1-0.4 mg/kg-day)

ESTIMATED LETHAL DOSE $(5-50 \mathrm{mg} / \mathrm{kg})$

$\underline{K E Y}$

KNOWN IMPACTS RANGE

TOXICITY IMPACTS EXPECTED AT

LEVELS OFF THE SCALE OF THE FIGURE

FIGURE 5.8

VANADIUM TOXICITY RANGES 
evidence suggests that in infants, gastrointestinal upset such as that caused by sulfate could increase their sensitivity to methemoglobinemia produced by nitrates. However, it is also possible sulfate-induced diarrhea could decrease the nitrate-reducing bacteria in the intestine, thereby decreasing nitrate toxicity.

Interaction between nitrate, sulfate, and hemoglobin also may occur. However, no studies have been found that address the specifics of this potential interaction under conditions of combined exposure to high concentrations of both nitrate and sulfate. Nitrate has been used to treat hydrogen sulfide poisoning. The hydrosulfide anion binds to methemoglobin to form sulfmethemoglobin, effectively removing circulating hydrosulfide. Additional data are needed to assess the likelihood of hydrosulfide formation with oral sulfate exposure or the subsequent formation or stability of sulfmethemoglobin.

The interaction of sulfate with molybdenum and copper is complex. Ruminants seem to be the most susceptible species to imbalances between these elements. In ruminants, copper prevents molybdenum accumulation in the liver and may antagonize molybdenum absorption. Molybdenum can produce a functional copper deficiency, but only in the presence of sulfate. It has also been suggested that sulfur can displace molybdate in the body (Casarett and Doull, 1991). In laboratory animal studies, molybdenum toxicity is more pronounced when dietary copper intake is low (EPA, 1994a). In ruminants, both copper and sulfates can protect against molybdenum toxicity and molybdenum and sulfur can block copper toxicity.

Molybdenum in the form of sodium molybdate has alleviated cadmium toxicity in rats. Cadmium absorption increases considerably with low intake of calcium, iron, or protein (Nordberg et al., 1985). Low body-iron stores can increase cadmium uptake fourfold (Flanagan et al., 1978)

Interactions between several similar metals can alter the predicted absorption, distribution in the body, metabolism, toxicity, or clearance of a metal of interest. For example, selenium interacts with a wide range of metals, including arsenic, bismuth, cadmium, cobalt, copper, lead, mercury, platinum, silver, tellurium, and thallium (Friberg et al., 1986). Selenium forms insoluble complexes with silver, copper, cadmium, and mercury. Selenium deficiency may develop in the presence of these other metals, as do cobalt and copper. The formation of these complexes can reduce the toxicity of both selenium and the other metal (Casarett and Doull, 1991). Most of these interactions have been observed in laboratory animals or in livestock, although the mechanisms are not completely understood. Often the selenium-metal complex binds in a stable complex to a larger protein than the metal alone, and this complex redistributes away from target tissues. Selenium and arsenic together can reduce their respective toxicities. However, some methylated metabolites of selenium can increase arsenic toxicity (DHHS, 1989). Sulfate can also interact with selenium, but the interaction is inconsistent. Sulfate can reduce some but not all toxic effects of selenium (such as liver damage at high doses) (DHHS, 1989). 
Because ingesting high levels of sulfate produces diarrhea that will lead to dehydration and ingesting high levels of sodium leads to water retention, a physiological interaction might be expected with simultaneous ingestion of both. However, available data do not predict the net effects of chronically ingesting sulfate and sodium at high concentrations. Although high-concentration sodium solutions are used to treat diarrhea-induced hyponatremia, the electrolyte concentrations are physiologically balanced. Disproportionately high sodium levels could intensify the electrolyte loss produced by severe diarrhea.

Oral administration of vanadium alone may interfere with copper metabolism by inhibiting the intestinal absorption of copper.

No information on uranium interactions with other metals has been found. However, the common target organ suggests potential interactions between uranium, vanadium, cadmium, and arsenic, resulting in increased kidney toxicity. Diarrhea-induced dehydration may lead to excessive concentration of the contaminants (those excreted in urine) in the kidney, enhancing the predicted toxicities of these contaminants.

\subsection{CONTAMINANT TOXICITY VALUES}

The EPA Office of Research and Development has calculated acceptable intake values reference doses (RfD) for long-term (chronic) exposure to noncarcinogens. These values are estimates of route-specific exposure levels not expected to cause adverse health effects when exposure occurs for a significant portion of a lifetime. The RfDs include safety factors to account for uncertainties associated with limitations of the toxicological database, including extrapolating animal studies to humans and response variabilities in sensitive individuals. These values are updated quarterly and are published in the HEAST tables (EPA, 1994b); some are also provided through the EPA's IRIS database (EPA, 1994a). Table 5.1 summarizes the most recent oral RfDs for the noncarcinogenic contaminants of potential concern and the constituents in background ground water that exceed acceptable intake values.

The EPA currently classifies all radionuclides as Group A, or known human carcinogens, based on their property of emitting ionizing radiation and on the evidence provided by epidemiological studies of radiation-induced cancer in humans. Toxicity values published in HEAST and IRIS correlate carcinogen intake over a lifetime with the increased excess cancer risk from that exposure. Table 5.2 gives the most recent cancer slope factors for the uranium-234 and -238 radioactive decay series and for arsenic, a chemical carcinogen. 
Table 5.2 Toxicity values: potential carcinogenic effects

\begin{tabular}{|c|c|c|c|c|}
\hline Parameter & $\begin{array}{l}\text { Oral slope } \\
\text { factor } \\
(p C i)^{-1}\end{array}$ & $\begin{array}{c}\text { Weight of } \\
\text { evidence } \\
\text { classification }\end{array}$ & Type of cancer & $\begin{array}{l}\text { Slope factor basis/ } \\
\text { slope factor source }\end{array}$ \\
\hline Arsenic $^{\mathrm{a}}$ (inorganic) & $1.8 E+0$ & A & Skin & Water/IRIS ${ }^{b}$ \\
\hline Lead-210 & 5.1E-10 & A & Bone & Water/HEAST \\
\hline Polonium-210 & $1.5 E-10$ & A & $\begin{array}{l}\text { Liver, kidneys, } \\
\text { spleen }\end{array}$ & Water/HEAST \\
\hline Radium-226 & $1.2 \mathrm{E}-10$ & A & Bone & Water/HEAST \\
\hline Thorium-230 & $1.3 E-11$ & A & Bone & Water/HEAST \\
\hline Uranium-238 & $1.6 E-11$ & A & c & Water/HEAST \\
\hline Uranium-234 & $1.6 \mathrm{E}-11$ & A & c & Water/HEAST \\
\hline
\end{tabular}

${ }^{a}$ Chemical carcinogen (milligrams per kilogram per day).

bSlope factor based on oral unit risk of 5E-05 (IRIS, 1994a).

CNo human or animal studies definitely associate oral exposure to natural uranium with development of cancer. 


\subsection{HUMAN RISK EVALUATION}

To evaluate human health risks to an individual or population, the results of the exposure assessment are combined with the results of the toxicity assessment. As discussed in Section 5.0, potential adverse health effects are a function of how much of the contaminant an individual takes in. At lower levels, some contaminants are beneficial to health because they are essential nutrients. At higher levels these same elements can cause adverse health effects or even death. In this section, intake distributions for the contaminants of potential concern presented in Section 4.0 are combined with the toxicity ranges presented in Section 5.0 to graphically show the potential for adverse health effects from these levels of exposure through drinking water.

This risk assessment evaluates the greatest potential risks from site-related ground water contamination at the Bowman site. Risks are based on the highest levels of the contaminants of potential concern observed in the shallow ground water system based on a review of all available site data. Levels of these constituents were greater in the shallow ground water system than in the lower zone. Any risk from contaminant concentrations in the lower zone would be expected to be less.

Risk from naturally occurring constituents in background ground water was not quantified separately; potential incremental risks from site-related contaminants would overlap risks from background. This risk assessment addresses overall potential risk at the site.

\subsection{POTENTIAL NONCARCINOGENIC HEALTH EFFECTS}

Results from the exposure assessment showing either the highest intake-tobody-weight ratios (i.e., highest doses) or the toxicologically most sensitive group are used to evaluate potential health effects for noncarcinogens. For arsenic, molybdenum, selenium, sodium, uranium, and vanadium, the highest intake-per-body-weight group is children 1 to 10 years old. Infant exposures are used to evaluate the health risks of sulfate because infants are a toxicologically sensitive population for this chemical. Nitrate toxicity is not addressed independently in this risk assessment because, although present at the site, nitrate is not attributable to the ashing process. However, where potential interactions between nitrate and other contaminants of potential concern may influence the assessment of potential adverse health impacts, toxicity to infants is considered.

More than 75 percent of the probability distribution for molybdenum is in the range of mild toxic effects (above approximately $0.01 \mathrm{mg} / \mathrm{kg}$-day) (Figure 6.1). Mild effects may include physiologic changes such as increased copper and increased uric acid synthesis, leading to gout-like symptoms. Higher exposure levels (greater than $0.4 \mathrm{mg} / \mathrm{kg}$-day), which are not expected at this site, would lead to gout, a severe metabolic disorder characterized by excessive uric acid production. However, site-related exposures are not expected to reach levels associated with severe gout-like symptoms. Up to 99 percent of the probable intakes are above the oral RfD for molybdenum $(0.005 \mathrm{mg} / \mathrm{kg}$-day). However, 


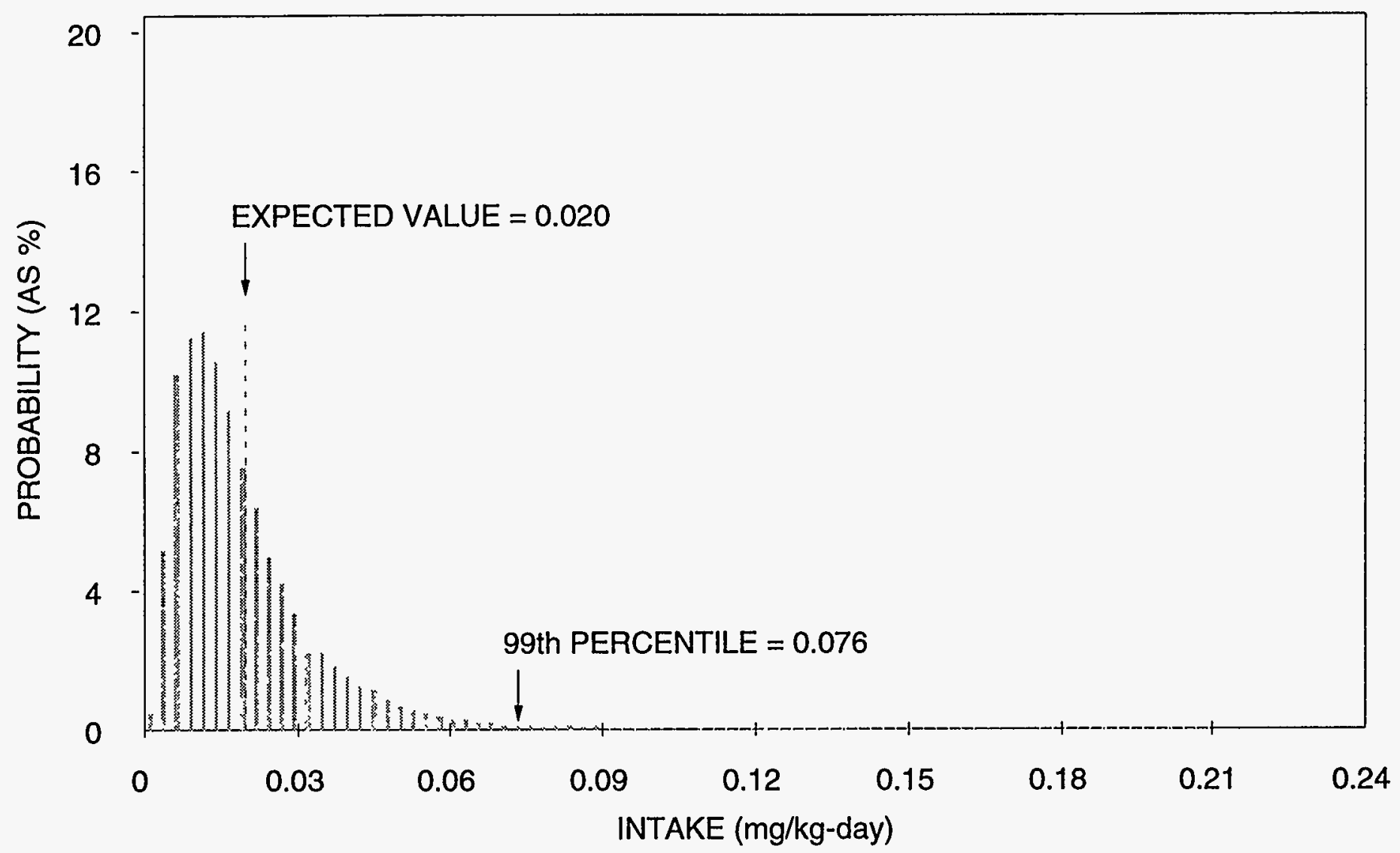

$\sqcup$ NUTRITIONAL INTAKE LEVELS

U DIETARY INTAKE LEVELS

NOTE: OVER $75 \%$ OF POTENTIAL EXPOSURES

TO MOLYBDENUM ARE IN THE RANGE

$\triangle$ ORAL REFERENCE DOSE (HEAST) $(0.005 \mathrm{mg} / \mathrm{kg}$-day) OF MILD TOXIC EFFECTS.

$\ldots \rightarrow$ NO OBSERVED ADVERSE EFFECT LEVEL

$\cdots \longrightarrow$ MILD TOXICITY - INCREASED COPPER EXCRETION AND INCREASED URIC ACID SYNTHESIS $\cdots$ GOUT

FIGURE 6.1

HEALTH EFFECTS OF POTENTIAL MOLYBDENUM EXPOSURE RANGES FOR CHILDREN BOWMAN, NORTH DAKOTA, SITE 
adverse effects likely would not occur at these exposure doses. Increased potential for adverse health effects caused by the 30-percent increase in intake estimated for the ingestion of milk and meat (Section 4.2) would not be expected. A 30-percent increase $(0.006 \mathrm{mg} / \mathrm{kg}$-day) in the expected molybdenum intake value plotted on Figure 6.1 would not influence the potential for toxic effects.

In Figure 6.2., almost 75 percent of the exposure distribution for sulfate is above the range that would cause mild diarrhea (approximately $100 \mathrm{mg} / \mathrm{kg}$-day). A portion of the potential exposures are above the range that would cause severe diarrhea (greater than $400 \mathrm{mg} / \mathrm{kg}$-day), which can lead to dehydration and even death in infants under chronic conditions. Ingesting meat containing high sulfate levels could increase sulfate exposures about 15 percent. However, this is not likely to increase the toxicity potential for adults and would not be a viable pathway for infants.

Contributions from other dietary and environmental sources could alter the interpretation of health risks to infants from sulfate. Toxicity to infants would be increased by the presence of nonsite-related nitrate in ground water because impacts from nitrate and sulfate are additive. It is also important to note that the exposure distribution for infants is based on tap water intake rates across a population that includes breast-fed and canned formula-fed infants. Infants consuming powdered formula reconstituted with well water would be in the upper percentiles of this exposure distribution and could be at higher risk of severe diarrhea and impacts from other sources.

Chronic sodium exposure would be associated with the development of hypertension in children as well as in adults. In Figure 6.3,65 percent of the exposure distribution for sodium is above the recommended limit for dietary intake ( $34 \mathrm{mg} / \mathrm{kg}$-day). More than 80 percent of the distribution is above the levels that may produce hypertension in humans. However, it has been shown that dietary intake commonly ranges from 50 to $90 \mathrm{mg} / \mathrm{kg}$-day. Sodium exposure could increase almost 38 percent with the concurrent ingestion of meat (12.5 percent) and milk ( 25 percent) concentrated with sodium. This additional exposure may increase the risk of hypertension in adults but the individual impacts are not measurable relative to the potential impacts from drinking water alone.

High-sodium solutions with physiologically balanced electrolyte concentrations are used to alleviate diarrhea-induced hyponatremia. It is not possible to predict the net effect of simultaneous chronic ingestion of sodium and sulfate at high concentrations in drinking water under conditions of unbalanced electrolytes.

At least 95 percent of the entire estimated exposure distributions for selenium, arsenic, and vanadium are below levels known to cause even mild adverse health effects, and are within the no-adverse-effects-levels (Figures 6.4, 6.5, and 6.6). More than 50 percent of the potential exposures to selenium fall below the oral RfD. More than 60 percent of the potential exposures to arsenic 


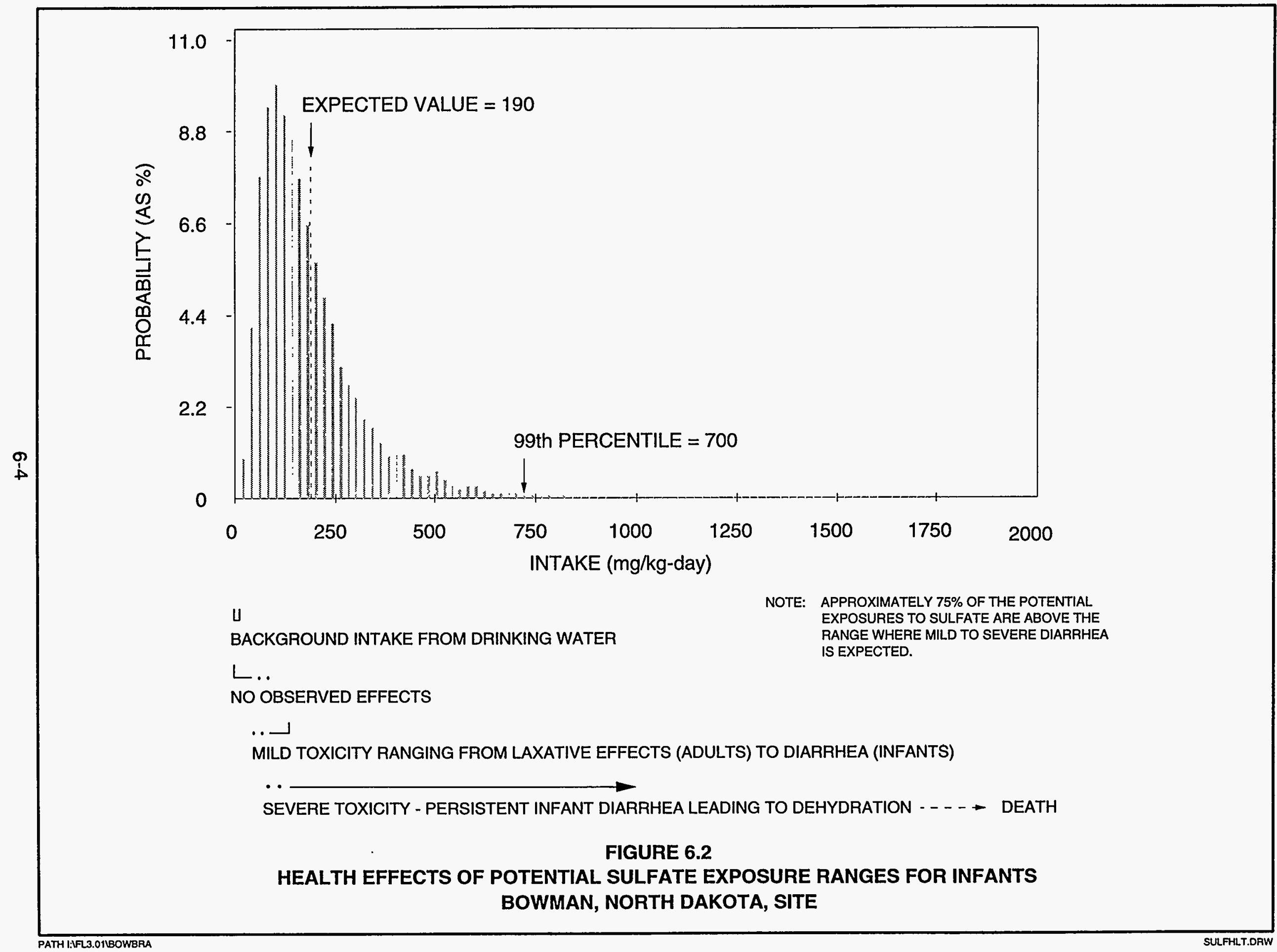




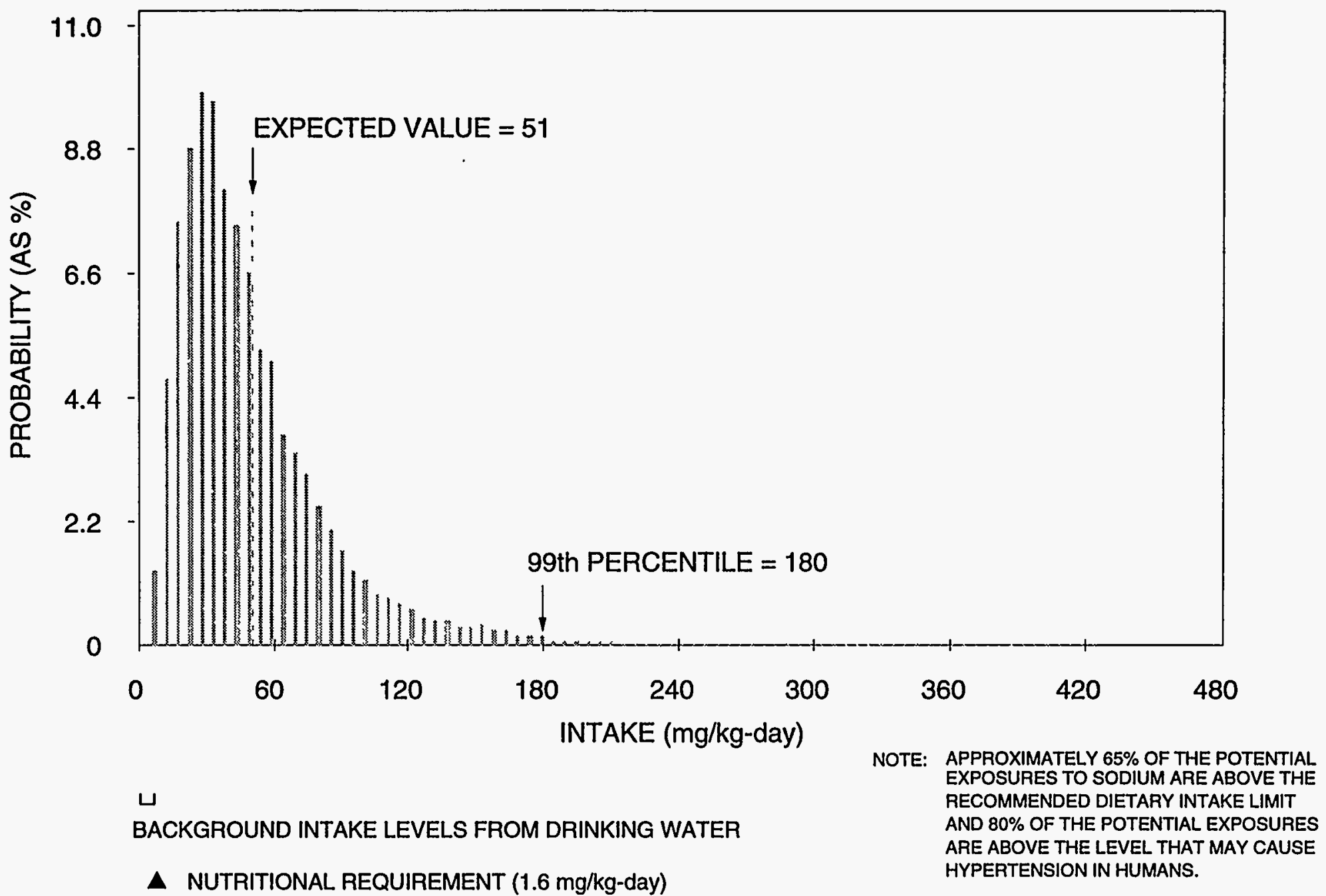

$\triangle$ NATIONAL RESEARCH COUNCIL RECOMMENDED LIMIT FOR DIETARY INTAKE ( $34 \mathrm{mg} / \mathrm{kg}$-day)

HYPERTENSION MAY OCCUR IN HUMANS

... - ...

DIETARY INTAKE LEVELS

FIGURE 6.3

HEALTH EFFECTS OF POTENTIAL SODIUM EXPOSURE RANGES FOR CHILDREN BOWMAN, NORTH DAKOTA, SITE 


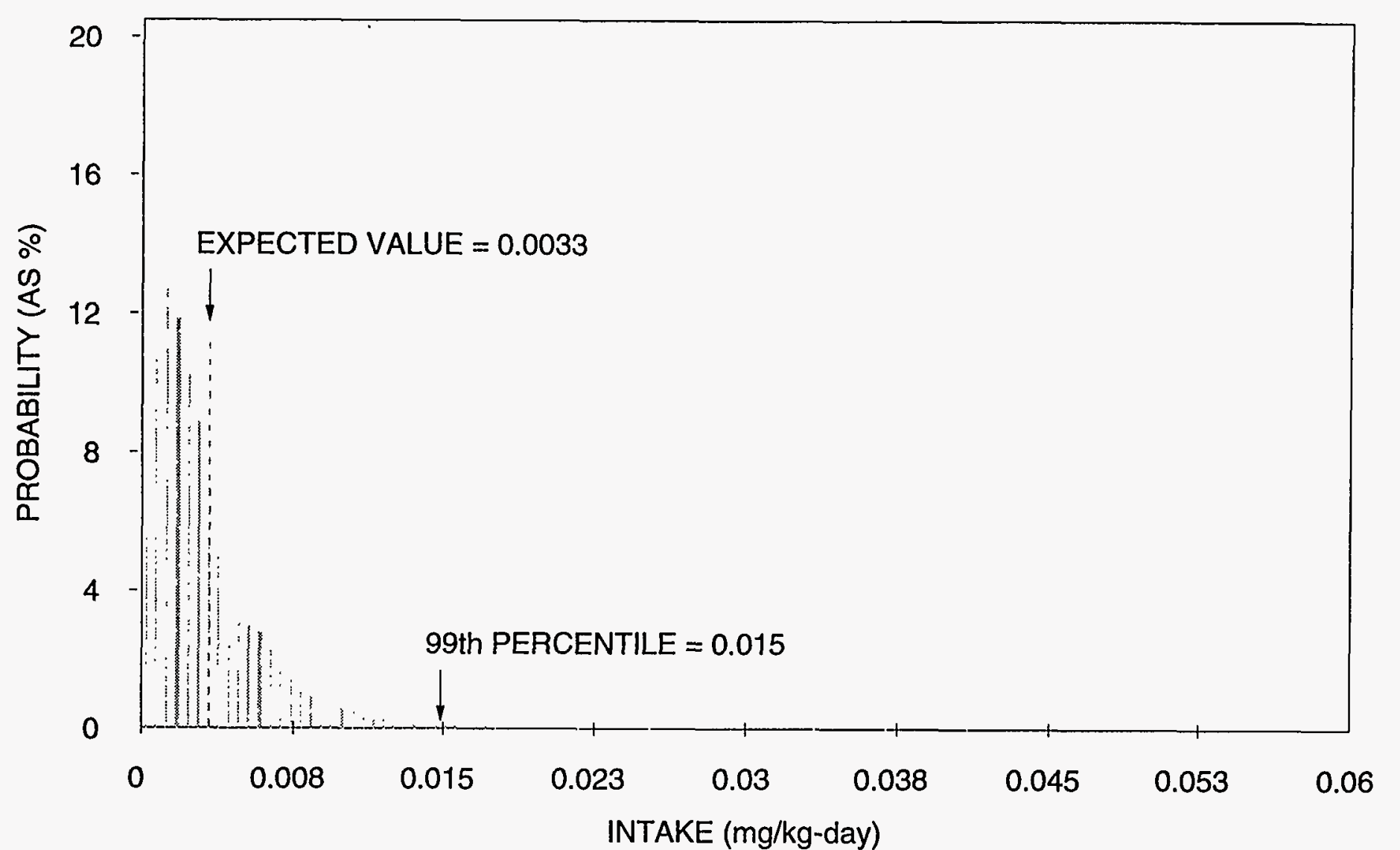

$\sqcup$ NUTRITIONAL INTAKE LEVELS

NOTE: UP TO 95\% OF THE POTENTIAL EXPOSURES

TO SELENIUM ARE BELOW LEVELS EXPECTED

TO CAUSE MILD TOXIC EFFECTS AND GREATER

THAN $50 \%$ OF THE POTENTIAL EXPOSURES

A ORAL REFERENCE DOSE (HEAST) $(0.005 \mathrm{mg} / \mathrm{kg}$-day)

ARE BELOW THE ORAL REFERENCE DOSE.

. . - . N NO OBSERVED EFFECT LEVEL

- MILD TOXICITY - NAIL AND HAIR BRITTLENESS/LOSS

$\longrightarrow \overrightarrow{S E L E N O S I S}$

FIGURE 6.4

HEALTH EFFECTS OF POTENTIAL SELENIUM EXPOSURE RANGES FOR CHILDREN

BOWMAN, NORTH DAKOTA, SITE 


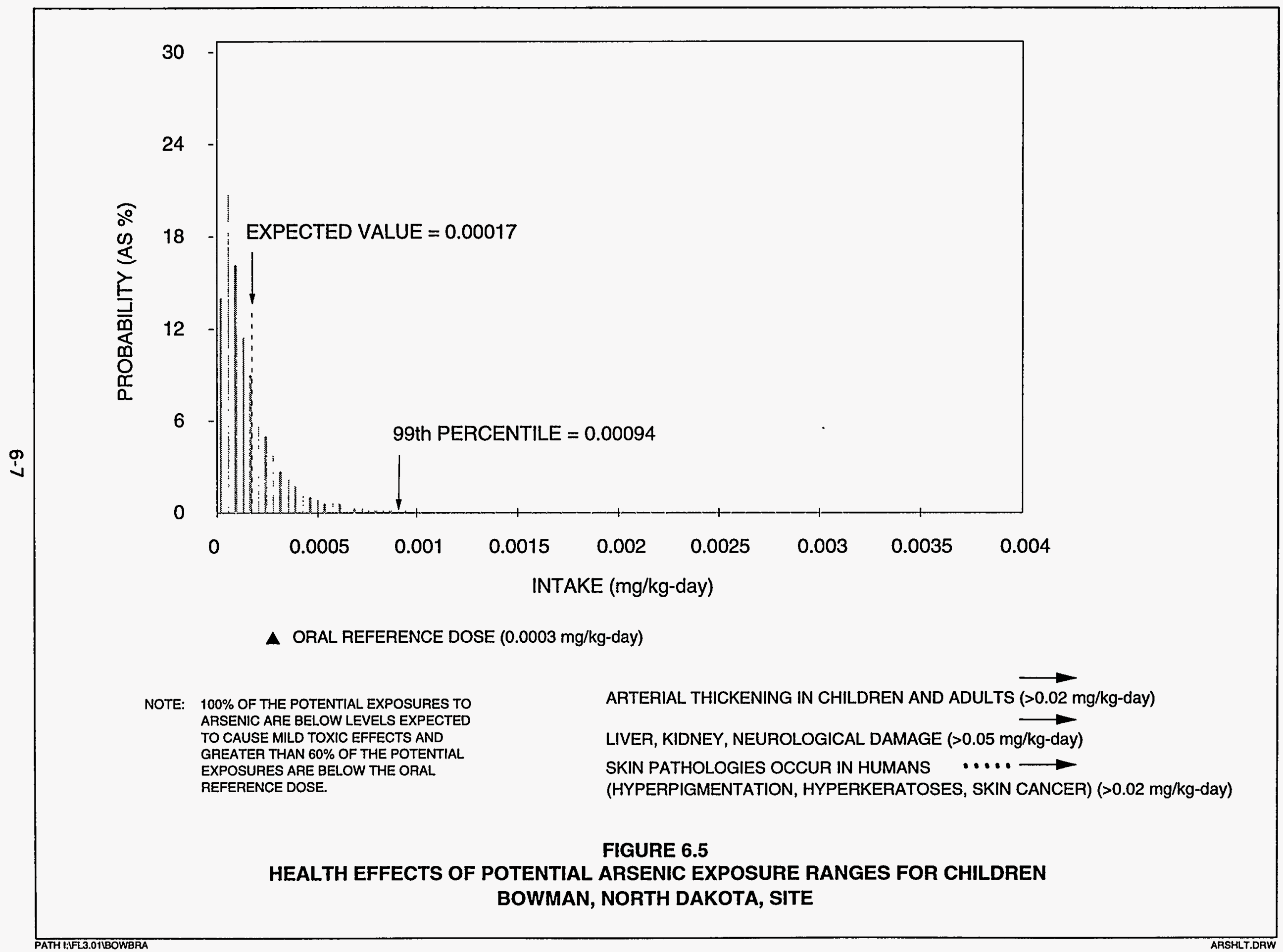




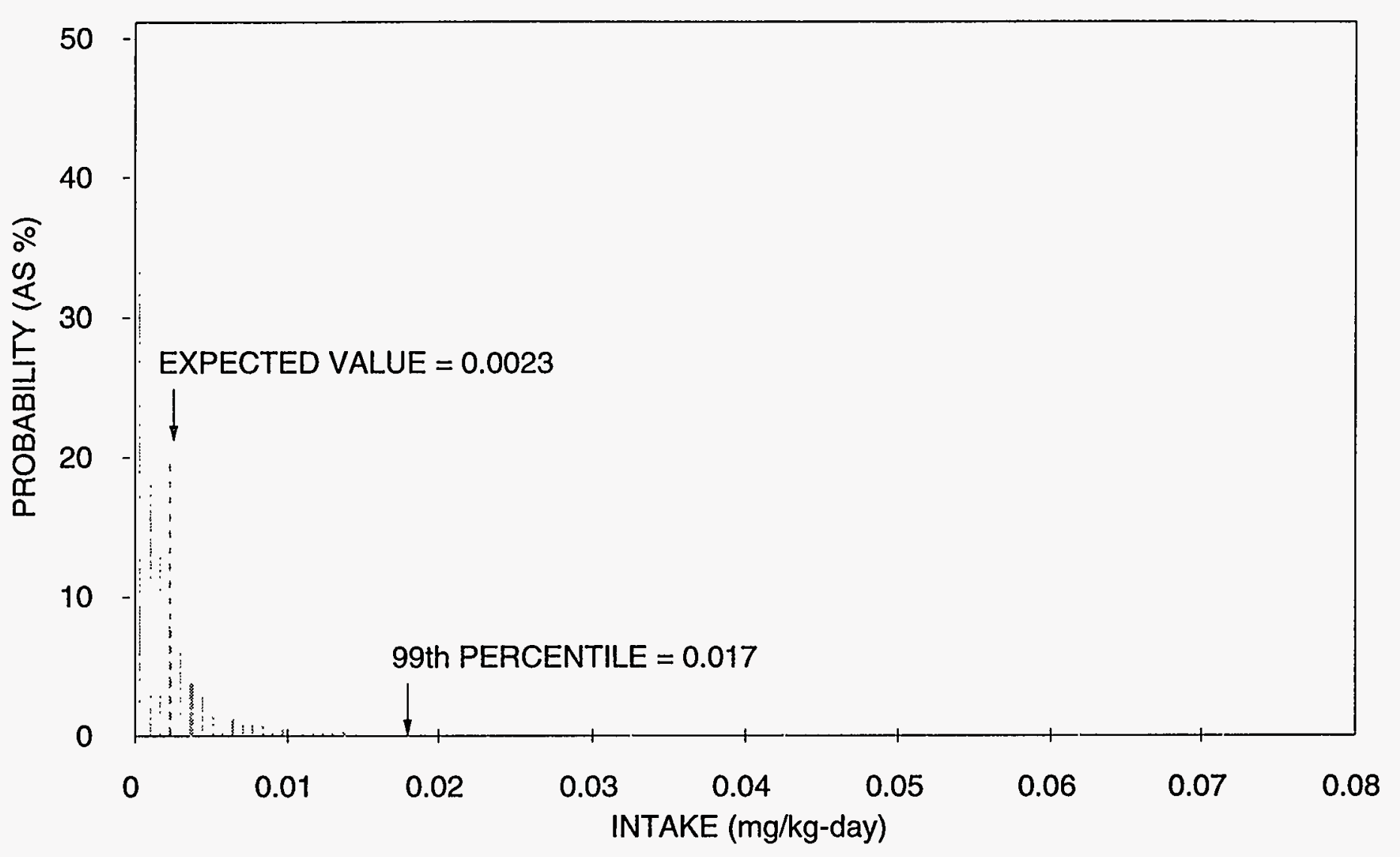

I DIETARY INTAKE LEVELS

$\triangle$ ORAL REFERENCE DOSE (HEAST) $(0.007 \mathrm{mg} / \mathrm{kg}$-day)

NOTE: $\quad 100 \%$ OF THE POTENTIAL EXPOSURES TO VANADIUM ARE BELOW LEVELS EXPECTED TO CAUSE MILD TOXIC EFFECTS AND APPROXIMATELY $75 \%$ OF THE POTENTIAL EXPOSURES ARE BELOW THE ORAL REFERENCE DOSE.

TOXICITY TRANSIENT CHOLESTEROL DROP, CRAMPS, GREEN TONGUE (0.1-0.4 mg/kg-day)

FIGURE 6.6

HEALTH EFFECTS OF POTENTIAL VANADIUM EXPOSURE RANGES FOR CHILDREN BOWMAN, NORTH DAKOTA, SITE 
fall below the oral RfD. Approximately 75 percent of the potential exposures to vanadium fall below the oral RfD. Therefore, toxic effects would not be expected from the potential intake rates of these contaminants. Even with a 60 percent increase in selenium exposure from the predicted effects of filtering on sample analysis, most of the predicted exposures would remain below levels that cause mild toxicity.

Sixty percent of the exposure distribution for uranium is less than 2 orders of magnitude below the lowest exposure level resulting in an adverse health effect, and falls entirely within the no-observed-effect-level. However, 95 percent of the anticipated intakes are above the EPA oral RfD of $0.003 \mathrm{mg} / \mathrm{kg}$-day (Figure 6.7). This discrepancy occurs largely because the toxicological database for uranium toxicity is incomplete; therefore, the EPA includes this large uncertainty in the oral RfD for acceptable intake. Uranium has not been demonstrated to serve a beneficial purpose in biological systems; therefore, unlike nutrient metals, a toxicity threshold for uranium is difficult to define. The estimated intakes of uranium have not been associated with adverse health effects in humans or test animals. However, due to the low level of certainty in the toxicological data, it is significant that almost the entire predicted exposure range is above the $R f D$.

\section{Summary}

Arsenic, molybdenum, selenium, sodium, sulfate, uranium, and vanadium are the noncarcinogenic contaminants of potential concern for site-related human health impacts from ingesting contaminated shallow ground water at the Bowman site. There is potential for mild noncarcinogenic toxic effects to humans from the estimated intakes of molybdenum, sulfate, and sodium through the drinking water pathway. Estimated intakes for selenium, arsenic, and vanadium do not correlate with expected adverse health effects and are well below levels of potential concern. Noncarcinogenic impacts to human health are not expected in association with the estimated intakes for uranium. However, there is considerable uncertainty in this conclusion, considering the limited toxicological data available.

\subsection{POTENTIAL CARCINOGENIC HEALTH EFFECTS}

\section{Radioactive cancer risk}

Natural uranium has not been demonstrated to cause cancer in humans or animals following ingestion. However, all uranium isotopes are radioactive and, as such, are considered potential carcinogens. For ingestion of ground water at the Bowman site, the estimated carcinogenic risk for the uranium-234 and -238 radioactive decay series is based on the cancer slope factors developed by the EPA (Table 5.2).

The EPA acceptable cancer risk, according to the National Contingency Plan (NCP) is between 1 excess cancer in 10,000 and 1 excess cancer in 1,000,000 


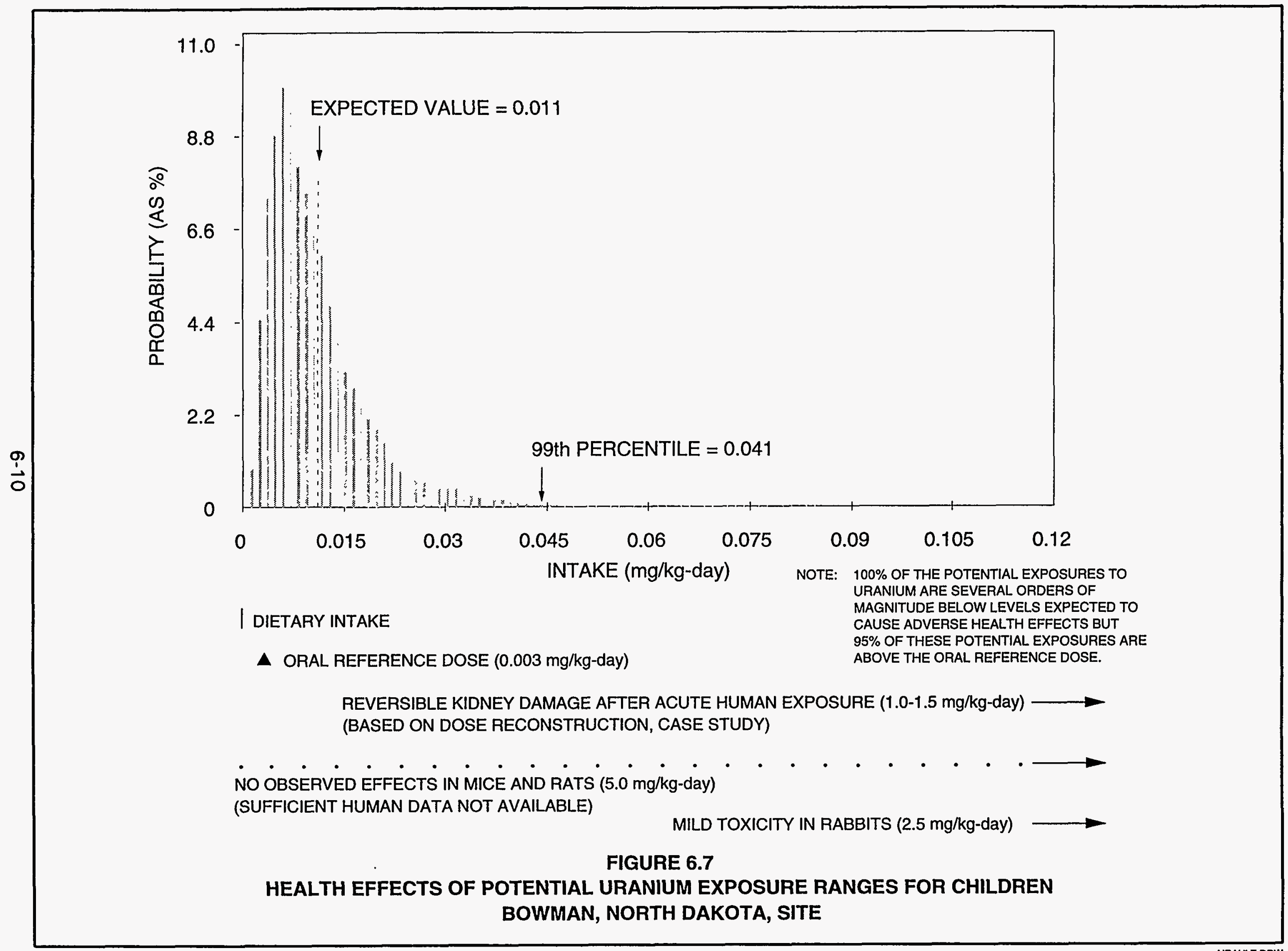


$\left(10^{-4}\right.$ and $\left.10^{-6}\right)$. Table 6.1 presents the carcinogenic risk associated with uranium and its radioactive, longer-lived progeny. The total cancer risk associated with uranium and its radioactive progeny at the Bowman site is 3 times the EPA upper limit of $10^{-4}$. Uranium and radium-226 consistently exceeded background levels on the site and in the site vicinity, respectively. As radionuclides, these contaminants decay to radioactive progeny. Therefore, the presence of each longer-lived radioactive progeny of the uranium decay series was evaluated for carcinogenic risk. Thorium-230, polonium-210, radium-226, and lead-210 were detected consistently on the site and in the site vicinity, although not at levels statistically above background. Because the data set is limited for these parameters, the total excess cancer risk is conservatively based on the maximum concentrations detected. Uranium concentrations were highest in on-site monitor well 531. The highest radium-226 concentration was detected in monitor well 530. As seen in Table 6.1, uranium contributes most of the excess cancer risk, and individually, most progeny would not impose unacceptable cancer risk.

Table 6.1 Excess lifetime cancer risk calculations for ground water ingestion by a hypothetical future adult resident, Bowman, North Dakota, site

\begin{tabular}{lcccc}
\hline \multicolumn{1}{c}{ Radionuclide } & $\begin{array}{c}\text { Exposure point } \\
\text { concentration } \\
\text { pCi/L }\end{array}$ & $\begin{array}{c}\text { Intake } \\
\text { (pCi/lifetime) }\end{array}$ & $\begin{array}{c}\text { Ingestion slope } \\
\text { factor } \\
\text { (pCi) }\end{array}$ & $\begin{array}{c}\text { Excess } \\
\text { lifetime } \\
\text { cancer risk }^{\mathbf{b}}\end{array}$ \\
\hline Uranium ${ }^{\mathrm{c}}$ & 274 & $9,590,000$ & $1.6 \mathrm{E}-11$ & $2 \mathrm{E}-04$ \\
Lead-210 & 4.1 & 143,500 & $5.1 \mathrm{E}-10$ & $7 \mathrm{E}-05$ \\
Polonium-230 & 1.2 & 42,000 & $1.5 \mathrm{E}-10$ & $1 \mathrm{E}-05$ \\
Thorium-230 & 1.6 & 56,000 & $1.3 \mathrm{E}-11$ & $7 \mathrm{E}-07$ \\
Radium-226 & 4.3 & 150,500 & $1.2 \mathrm{E}-10$ & $2 \mathrm{E}-05$ \\
\hline
\end{tabular}

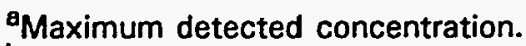

Intake $\times$ slope factor $=$ excess lifetime cancer risk.

CUranium-234 and uranium-238 combined. The oral slope factor is the same for both isotopes.

Figure 6.8 shows the potential carcinogenic risks for uranium alone, based on an exposure distribution. Approximately 75 percent of the distribution falls within the acceptable range but approximately 25 percent would be a greater than 1 in 10,000 excess cancers.

\section{Chemical cancer risk}

Arsenic is the only chemical carcinogen detected at the Bowman site. If contaminated ground water in the shallow ground water system were used as 


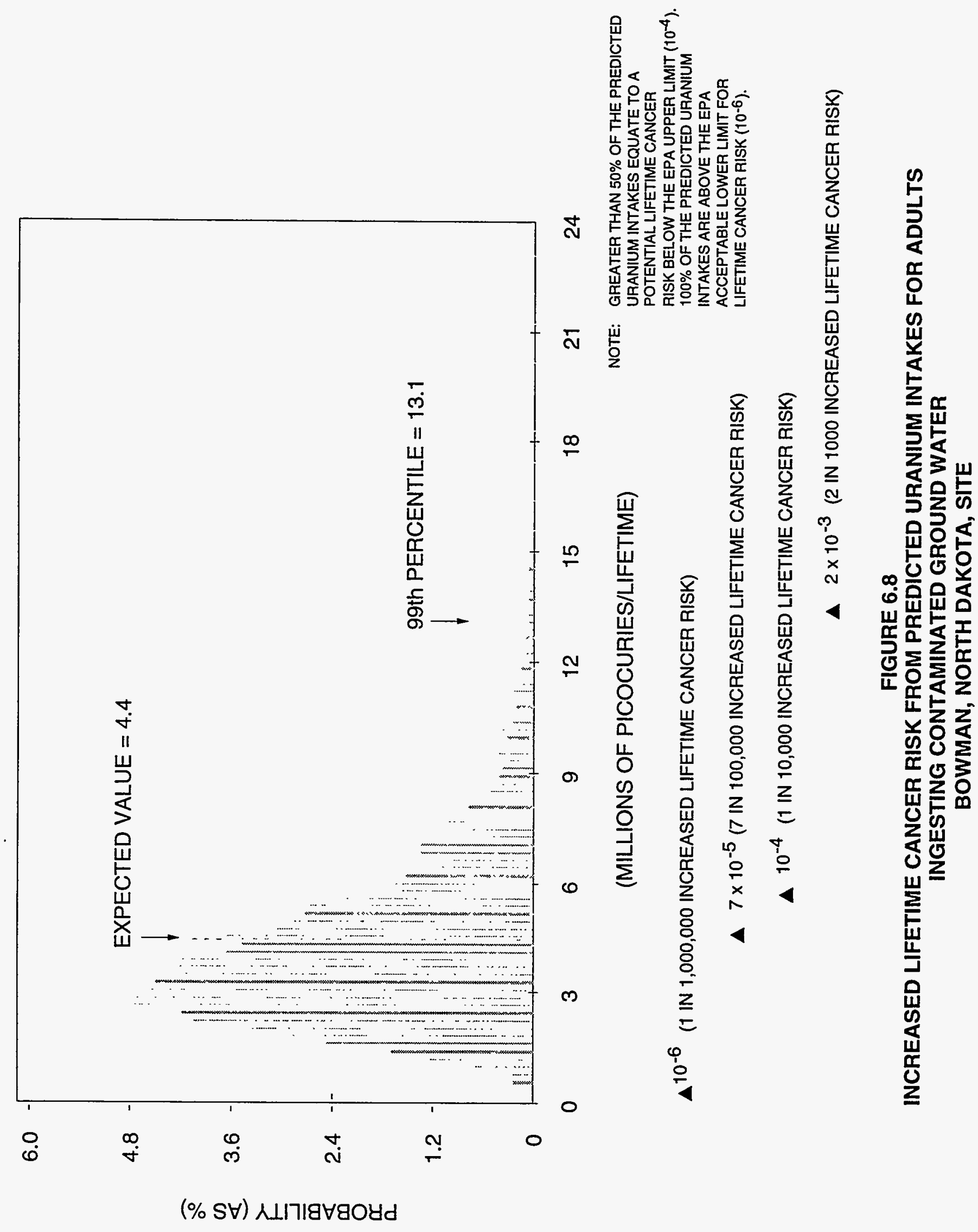


drinking water, the risk of skin cancer could increase as a result of chronic exposure to detected arsenic levels. Carcinogenic risk for chemical carcinogens is based on the average daily intake of the chemical per kilogram of body weight times the exposure duration, and averaged over a lifespan of 70 years.

Figure 6.9 presents the intake distribution for arsenic over a lifetime. Excess cancer risks calculations were based on the EPA oral slope factor of

$1.8 \mathrm{mg} / \mathrm{kg}$-day) for skin cancer development. Using the expected value, about 50 percent of the exposure distribution for arsenic ingested by adults falls within the NCP upper. guidance of 1 excess cancer in 10,000. The 99th percentile equates to 5 times the acceptable limit or 5 excess cancers in 10,000 .

\subsection{LIMITATIONS OF RISK EVALUATION}

The following potential limitations apply to interpretations of this risk evaluation:

- This risk assessment evaluates only risks related to inorganic ground water contamination. The presence of organics was not investigated.

- This risk evaluation is based on exposure to levels of inorganic constituents attributable to processing activities. It does not separately consider the potential risk from exposure to naturally occurring constituents present in background ground water that are above health advisory levels and/or EPA MCLs applicable to the UMTRA Project.

- Subpopulations that might have increased sensitivity such as the elderly or individuals with preexisting disease, are not specifically addressed in the toxicity-range graphs.

- Some individuals may be more sensitive to the toxic effects of certain constituents for reasons that have not been determined.

- Data available to interpret potential adverse health effects may not always be sufficient to allow accurate determination of all health effects due to lack of human data or testing of dose ranges other than those expected at this site. For example, potential health risks from uranium at the levels identified for this site are basically unpredictable, given the little available toxicity information.

- Although plume movement is evaluated hydrologically and geochemically, the monitoring locations sampled may not have intercepted the most contaminated portion of the plume. Additionally, concentrations may increase or decrease as conditions change.

- Only the drinking water exposure pathway was considered in depth. However, other pathways that potentially could contribute to the intake were evaluated. 


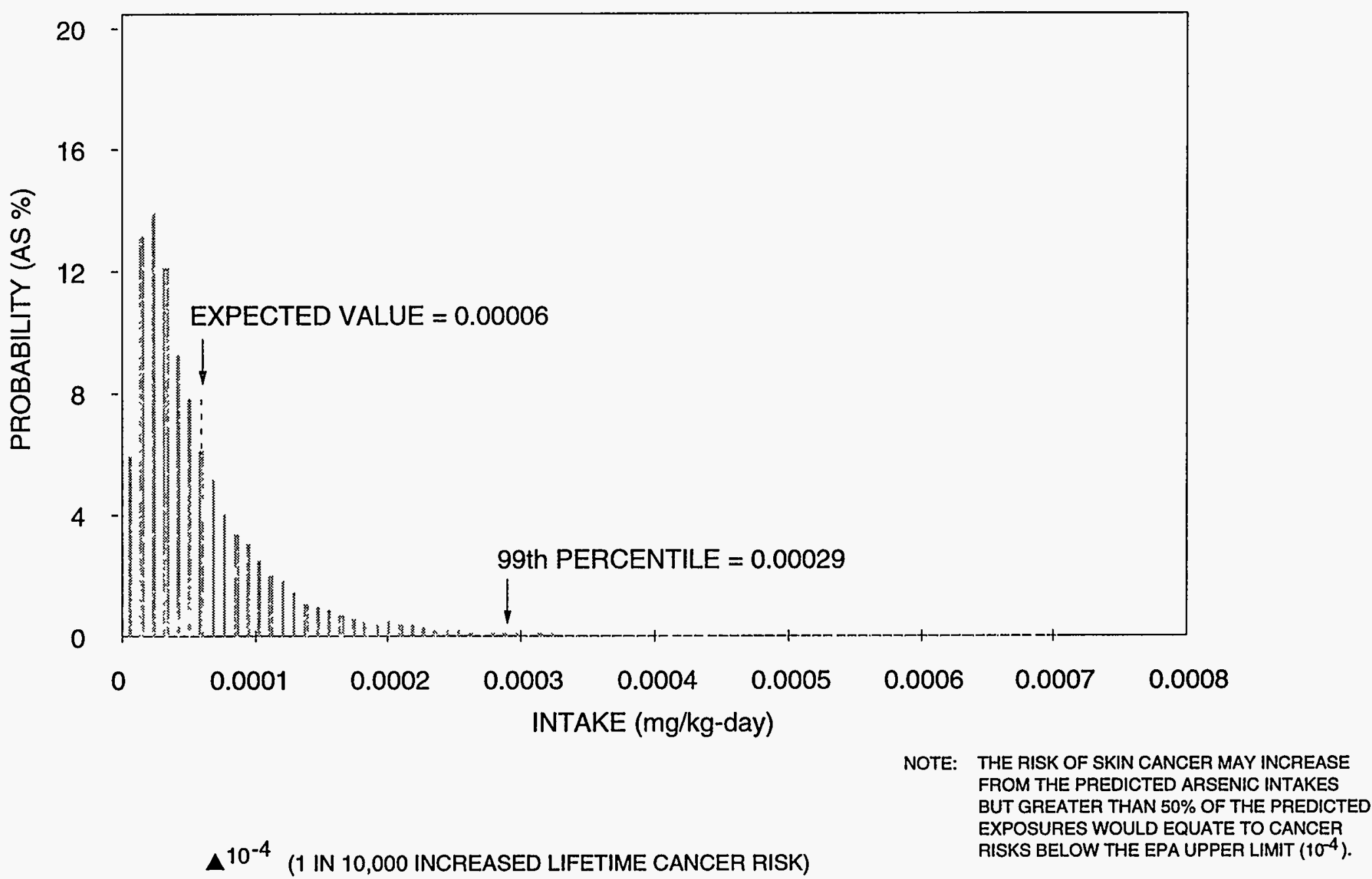

$\Delta^{5 \times 10^{-4}}$ (5 IN 10,000 INCREASED LIFETIME CANCER RISK)

FIGURE 6.9

INCREASED LIFETIME CANCER RISK FROM PREDICTED ARSENIC INTAKES FOR ADULTS

INGESTING CONTAMINATED GROUND WATER

BOWMAN, NORTH DAKOTA, SITE 
The evaluation presented here considered these limitations and compensated wherever possible by presenting toxicity ranges and probabilistic exposure assessments rather than point estimates to incorporate as much variability as could be reasonably defined. The impact of these potential limitations is discussed more fully in Section 8.2. 


\subsection{ENVIRONMENTAL EVALUATION}

This section assesses the potential for site-related contaminants to adversely affect the existing biological communities, grazing livestock, and other agricultural practices in the site area. Currently, the EPA has no guidance for quantifying potential impacts of the release of hazardous constituents. However, the EPA qualitative approach for ecological risk evaluations (EPA, 1989b) recommends conducting ecological assessments in phases to ensure the most effective use of resources while the necessary work is conducted. This phased approach consists of the following four increasingly complex stages: $1)$ identification of potentially exposed habitats, 2) collection of analytical data on affected media, 3) collection of biological data, and 4) toxicity testing. Results of the initial habitat inspections and media sampling and analysis will indicate the ecological risk potential. The assessment will then be complete, unless these initial stages indicate the potential for adverse impacts to ecological receptors from site contamination, when a higher level of analysis will be warranted.

The ecological risk assessment at the Bowman site consists of the four initial stages of the EPA approach, which are based on information on potentially affected habitats and on water quality data from several sampling rounds. The ground water quality data from the past 8 years and limited recent surface water and sediment quality data were used to make this initial ecological risk assessment. This qualitative stage of the EPA approach to ecological risk is a screening level assessment of potential risk of exposure to contaminated media at the site.

It is often difficult to determine if contaminants have affected the biological component of an ecosystem and to predict if observed effects on individual populations will damage the ecosystem. Sampling environmental media such as surface water can help assess possible ecological risk. However, a risk assumes there are both a source of contamination and a pathway to the biological communities. Therefore, the evaluation of potential ecological risk at the Bowman site includes the following information:

- Areas of contamination and the potential pathways by which contamination may enter either the aquatic and/or terrestrial biological communities in the site vicinity.

- Potential ecological receptors at the site.

- Contaminants of potential ecological concern.

- The potential for adverse impacts to livestock, ecological resources, and agricultural resources from the levels of contaminants of potential concern observed at the site.

In summary, this baseline risk assessment evaluates risk to ecological receptors from exposure to contaminated ground water through the future potential irrigation and ingestion pathways. Contaminant concentrations in ground water are compared to available surface water quality criteria to estimate the potential for adverse impacts to plants, wildlife, and livestock. Based on available criteria, contaminant levels found in ground water are not likely to impact wildlife or livestock. A future potential risk would be 
created for plants if ground water were used as irrigation water. No threatened or endangered or sensitive species were identified at the site. Neither current nor future potential exposure to aquatic biota is expected.

\subsection{EXPOSURE PATHWAYS}

Exposure requires a receptor organism, a source of contamination, and a pathway for that contamination to reach the receptor population or individual. Both current and potential future exposure pathways to ground water were considered for biota at the Bowman site.

Potentially impacted media at the site include surface water, sediments, and ground water. Currently, no direct exposure to contaminated ground water exists at the site. A potential future exposure pathway to ground water would be a hypothetical ground water-fed pond. Exposure to ground water through naturally occurring surface water is not expected at the site because ground water is not hydraulically connected to surface water in the area (DOE, 1990). Another future potential exposure pathway to ground water for plants would be through irrigation. Direct exposure to ground water by plant roots is not expected at the site.

Surface water in the Bowman site vicinity is very limited. Impacts by either contaminated ground water or contaminated surface runoff from soils are not expected at the site. A surface water exposure pathway to contaminated ground water is not expected for biota; therefore, it is not evaluated in this ecological risk assessment. The limited data available for surface water and the limited extent of surface water in the site vicinity preclude the need for a screening for site contamination. Overall, constituent levels observed in surface water are much lower than levels observed in contaminated ground water. No constituents attributable to the site are present in surface water.

The direct exposure to contaminated ground water by plants through root uptake is an unlikely pathway at the Bowman site because depth to ground water is at least $20 \mathrm{ft}(9 \mathrm{~m})$. Uptake from plants irrigated with contaminated ground water is considered a potential future exposure pathway.

A conservative approach was used for the potential future exposure pathway to contaminated ground water. A domestic well was assumed to intercept the most contaminated ground water at the site at some future time. Water from this hypothetical well could be used for livestock watering, a stock pond, and irrigation. The use of shallow ground water for commercial irrigation is not likely due to the low-yield ability of the shallow aquifer system in the site vicinity but irrigation of a small garden could occur.

\subsection{ECOLOGICAL RECEPTORS}

The ecological resources in the site vicinity that could be exposed to site-related contaminants are identified below. Potential impacts to these receptors are 
based on estimated exposures. Additional ecological characterization would be needed to measure the presence or absence of adverse impacts to specific individuals or populations in the site vicinity.

The following information on ecological receptors is based primarily on surveys conducted at the site in relation to the Threatened and Endangered (T\&E) Species Act and other National Environmental Policy Act (NEPA) requirements. Detailed field records for these surveys are kept in the UMTRA Project Document Control Center.

\subsubsection{Flora}

The Bowman site area is dominated by gently rolling hills vegetated by species typical of the short-grass prairie habitat. Some of the area is used for dryland farming; wooded areas in the form of shelter belts and a few small wetlands are also present in the region.

Five plant community types were identified at and immediately surrounding the site (Figure 7.1). Three plant communities are grass-dominated (TAC, 1986; 1987). The fourth plant community type is an ephemeral drainage west of the designated site area along an unnamed tributary to Spring Creek that supports some wetland vegetation. The area is not mowed or grazed and is dominated by cordgrass; blue grass, sedges, and rushes were also observed. A woody plant community is a shelterbelt for the farm complex just north of the site. Elm is the dominant tree species and some are up to $55 \mathrm{ft}(17 \mathrm{~m})$ tall. Smaller trees growing in this area are Russian olive and juniper. The ground cover of grass and herbs is dense in open areas and sparse in areas with a closed canopy. A U.S. Army Corps of Engineers-designated wetland area with ponded water is $0.75 \mathrm{mi}(1.2 \mathrm{~km})$ west of the site along U.S. Highway 12 (DOE, 1993).

\subsubsection{Terrestrial fauna}

A total of 32 species of mammals may occur in the site area; 12 species were been observed at or near the site. White-tailed deer were the most abundant big game species. A few pronghorn antelope and mule deer were observed in the rolling hills $0.75 \mathrm{mi}(1.2 \mathrm{~km})$ north of the site (DOE, 1993). These species may use the site area to a limited extent. Very few species of amphibians or reptiles are recorded for the Bowman site.

A total of 48 bird species were recorded in the site vicinity. Sixteen species were observed in the shelter belt areas; the western kingbird and mourning dove were the most common species observed. The sharp-tailed grouse was the only upland game bird observed near the site. The short-grass prairie habitat is optimum habitat for this species.

Five species of duck were observed at or near the site. Waterfowl were not observed within the boundaries of the designated site. Waterfowl were observed in the wetland pond west of the site along U.S. Highway 12. 


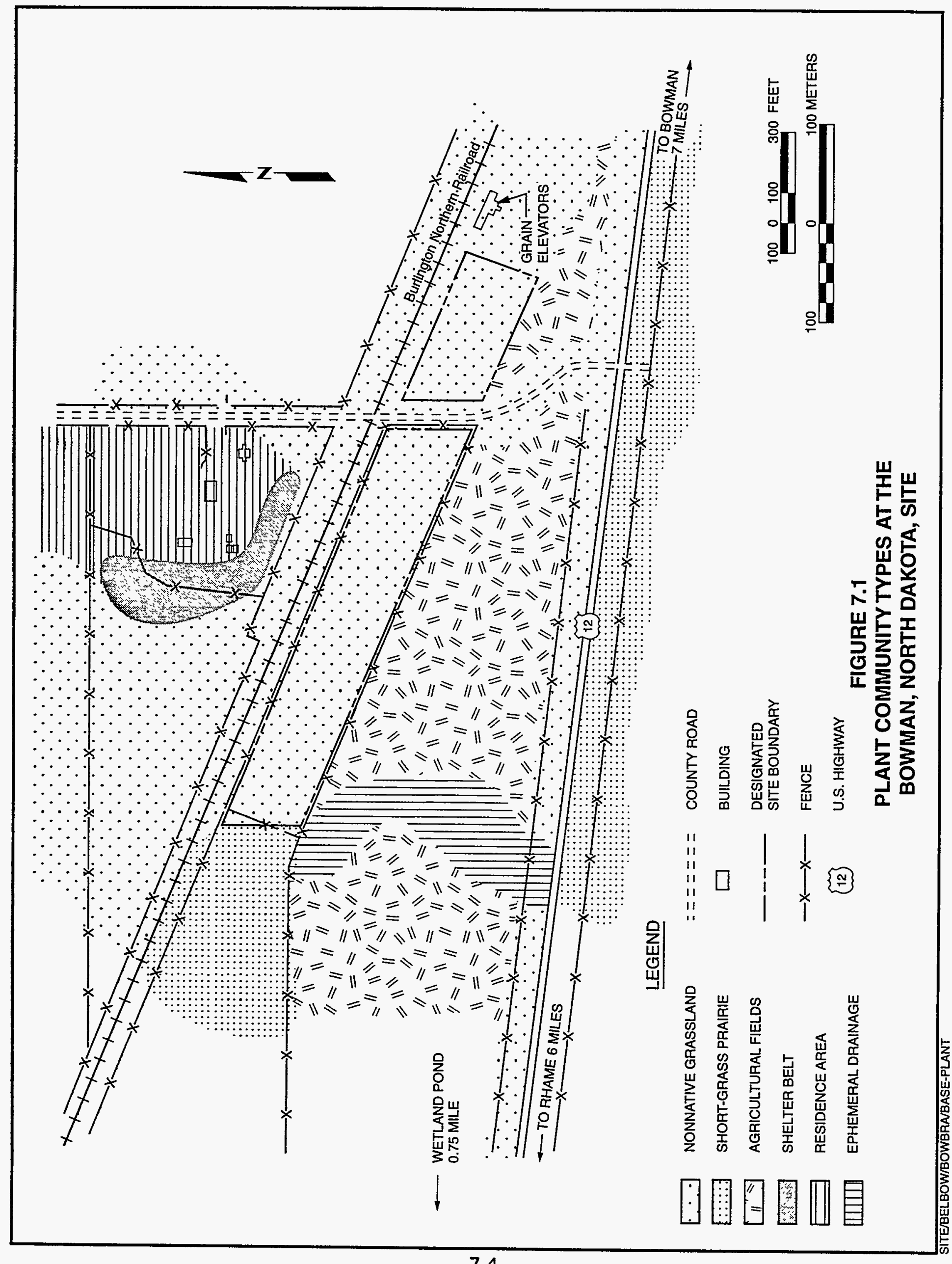


Eight species of birds of prey were observed in the site area. The great-horned owl and kestrel were observed in the shelterbelt and may nest there, although no nests were observed. The turkey vulture, golden eagle, northern harrier, Swainson's hawk, and red-tailed hawk were observed flying in the area; no evidence of these species nesting in the area was obtained. A ferruginous hawk was observed near the site and two inactive nests were observed during the 1986 and 1987 field surveys. These nests were not observed during the 1992 field survey.

\section{Threatened or endangered species}

T\&E species and other species of concern that may occur at the Bowman site were determined through consultation with the U.S. Fish and Wildlife Service and the North Dakota Game and Fish Department. As discussed in the sitespecific environmental assessment (DOE, 1993), five endangered species could occur at the site: the bald eagle, peregrine falcon, whooping crane, black-footed ferret, and the American burying beetle (DOE, 1993). The state indicated that no state-listed plant or animal species occur near the site (DOE, 1993). Five candidate species may occur near the site including the ferruginous hawk, regal fritillary butterfly, Baird's sparrow, and loggerheaded shrike. Historical records note the occurrence of the ferruginous hawk near the site. None of these species were observed during recent field studies.

\subsubsection{Aquatic organisms}

Data are not available on the presence of aquatic organisms and surveys for aquatic organism have not been conducted. Surface water is limited in the site vicinity and none exists at the site. The nearest surface water, approximately $0.75 \mathrm{mi}(1.2 \mathrm{~km})$ west of the site, is a wetland pond along an upgradient section of Spring Creek. The pond appears to be shallow (depth not measured) and covers approximately 0.1 ac $(0.4 \mathrm{ha})$ on each side of U.S. Highway 12. Fish were not observed during field surveys of the surface water bodies from which samples were collected.

\subsection{CONTAMINANTS OF ECOLOGICAL CONCERN}

In determining exposure to contaminated ground water from a hypothetical ground water-fed pond, the complete list of constituents above background levels on the site were considered as potential site-related contaminants. Because of the diversity of potential biological receptors, none of these potential contaminants were eliminated from the evaluation. Ground water concentrations of arsenic, boron, bromide, calcium, chloride, fluoride, magnesium, molybdenum, nitrate, phosphate, potassium, radium-226, selenium, silver, sodium, strontium, sulfate, uranium, vanadium, and zinc were evaluated for potential risk to aquatic biota, livestock, and plants through a comparison with available water quality criteria. 


\section{$7.4 \quad$ POTENTIAL RISKS TO BIOTA}

To evaluate the potential risks to biota from exposure to contaminants in ground water, contaminant concentrations in the most impacted on-site wells were compared to available surface water, irrigation, and sediment quality criteria. Potential risks to biota from levels of metals occurring naturally in background ground water in the site vicinity were not evaluated. Risks from site-related contaminants would overlap any risks associated with background conditions. The ground water quality data used in the human health risk evaluation were used in the ecological risk evaluation. One round of sediment samples was collected and analyzed for selenium, molybdenum, chromium, and uranium. Surface water quality data were not used in the qualitative assessment, comparing site conditions to available criteria.

Table 7.1 compares available criteria to the 95-percent upper confidence limit for mean concentrations of the constituents above background levels in on-site ground water. No federal or state criteria or standards are established to protect terrestrial wildlife via water exposure. Water quality criteria for aquatic organisms are limited. Water quality criteria for livestock also are limited, making comparisons difficult. Some recommended limits for irrigation water are included in the screening.

Of the 20 constituents determined to be above background levels in ground water at the site, boron, molybdenum, nitrate, sulfate, uranium, vanadium, and selenium could impact livestock and/or agricultural crops. Boron levels are close to the limits recommended for irrigation of crops. The boron criteria are based on continuous irrigation with contaminated water. Molybdenum concentrations are slightly above the suggested limit for livestock watering and considerably above the recommended limit for irrigation water. Some plants are susceptible to molybdenum uptake that could not only be phytotoxic to the plant but also indirectly expose grazing animals to molybdenum. Although not attributable to the ashing process, nitrate levels are just at the suggested limit for livestock drinking water. However, the literature indicates sublethal or chronic effects of nitrate exposures in livestock are extremely rare even at exposures greater that the potential exposures presented here (Carsen, 1992). Sulfate concentrations would be associated with the salinity and TDS of drinking water. TDS levels at approximately $5000 \mathrm{mg} / \mathrm{L}$ would be safe for all livestock except lactating or pregnant females (Carsen, 1992). Sulfate levels are above the suggested limit for livestock drinking water. Exposures to vanadium would be equal to the criteria level. However, adverse impacts have not been documented at these levels. Selenium is above criteria for livestock and irrigation water. Selenium in ground water may impact plants and/or cattle. Selenium toxicity in cattle is related to the balance of other metal nutrients in the diet and adverse effects likely would not occur under proper nutritional conditions. Plant uptake of selenium may lead to indirect exposure to selenium in grazing animals.

Current guidelines limit TDS for aquatic life, livestock drinking, and irrigation waters. TDS for ground water at the site in the most contaminated wells 
Table 7.1 Comparison of shallow ground water quality data with available surface water quality criteria for the protection of aquatic organisms, wildlife, and livestock, near the Bowman, North Dakota, site

\begin{tabular}{|c|c|c|c|c|}
\hline $\begin{array}{l}\text { Constituents above } \\
\text { background in shallow } \\
\text { ground water }\end{array}$ & $\begin{array}{c}\text { UCL } \\
\text { concentration } \\
\text { in ground water }\end{array}$ & $\begin{array}{c}\text { Aquatic life } \\
\text { water quality } \\
\text { value }\end{array}$ & $\begin{array}{c}\text { Water concentration } \\
\text { protective of } \\
\text { livestock }\end{array}$ & $\begin{array}{c}\text { Concentration in } \\
\text { irrigation water } \\
\text { protective of plants }\end{array}$ \\
\hline Arsenic & 0.007 & 0.19 & 0.5 & 0.10 \\
\hline Boron & 1.3 & $1.0^{c}$ & 5.0 & 0.75 \\
\hline Bromide & 0.30 & NA & NA & NA \\
\hline Calcium & 340 & NA & 1000 & NA \\
\hline Chloride & 61 & $230^{d}$ & NA & NA \\
\hline Fluoride & 0.95 & NA & 2.0 & 1.0 \\
\hline Magnesium & 580 & NA & NA & NA \\
\hline Molybdenum & 0.64 & $50\left(0.79^{8}\right)$ & 0.5 & 0.010 \\
\hline Nitrate & 110 & $90^{f}$ & 100 & NA \\
\hline Phosphate & 1.1 & NA & NA & NA \\
\hline Potassium & 39 & NA & NA & NA \\
\hline Radium-226 (pCi/L) & 3.0 & 5 & NA & NA \\
\hline Selenium & 0.12 & 0.005 & 0.05 & 0.020 \\
\hline Silver & 0.014 & $0.00012^{g}$ & NA & NA \\
\hline Sodium & 1550 & NA & NA & NA \\
\hline Strontium & 3.9 & NA & NA & NA \\
\hline Sulfate & 5780 & NA & $1000^{h}$ & NA \\
\hline Uranium & 0.33 & $48^{i}$ & 0.2 & NA \\
\hline Vanadium & 0.15 & NA & 0.10 & 0.10 \\
\hline Zinc & 0.05 & $1.6^{i}$ & 50 & 2.0 \\
\hline
\end{tabular}

a Value obtained from the Standards of Water Quality for state of North Dakota (Rule 33-16-02), North Dakota State Department of Health (NDSDH, 1991), unless specified otherwise. The values for metals refer to the acid soluble portion (filtered). These values are standards protective of aquatic life via chronic exposure.

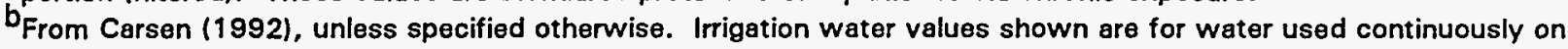
all soils.

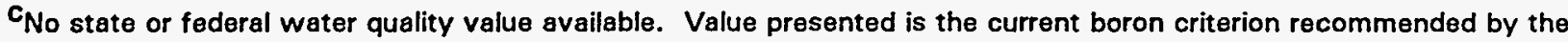
U.S. Fish and Wildife Service (FWS) for the protection of aquatic life (Eisler, 1990).

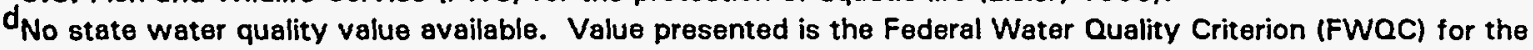
protection of freshwater aquatic life via chronic exposure (EPA, 1992b).

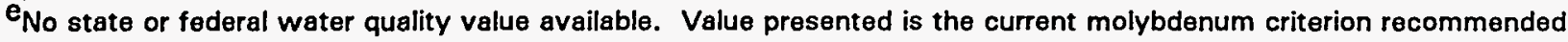
by the FWS for the protection of aquatic organisms, for newly fertilized eggs of rainbow trout, which are sensitive to molybdenum concentrations above $0.79 \mathrm{mg} / \mathrm{L}$ (Eisler, 1989).

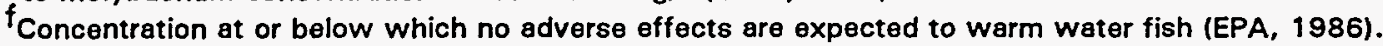

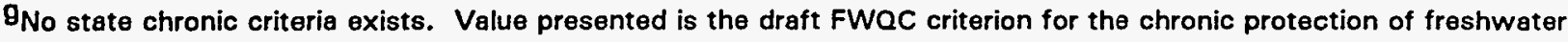
aquatic life (EPA, 1987).

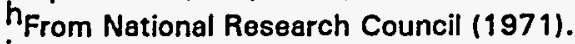

No state or federal water quality value available. Value presented is the state of Colorado chronic standard for the protection of freshwater aquatic life $(\mathrm{CDH}, 1991)$. The standard is calculated using a water hardness-related equation.

jWater hardness-related state stenderd (NDSDH, 1991). Criterion presented was calculated using the mean hardness $(2300 \mathrm{mg} / \mathrm{L})$ determined from concentrations of calcium and magnesium in the plume wells.

$U C L=$ upper 95 percent confidence limit of the mean.

Concentrations reported in milligrams per liter unless otherwise noted.

NA - not available. 
ranges from 2390 to $9680 \mathrm{mg} / \mathrm{L}$ with an average of $6374 \mathrm{mg} / \mathrm{L}$. These values are below the recommended limit for aquatic life $(15,000 \mathrm{mg} / \mathrm{L})$ and livestock drinking water $(10,000 \mathrm{mg} / \mathrm{L})$ but are above the recommended limit for irrigation water (1000 to $2000 \mathrm{mg} / \mathrm{L})$. Guidelines are also available for the specific conductance of irrigation water. The specific conductance range for water that may have detrimental effects on sensitive agricultural crops is 750 to 1500 microholms per centimeter $(\mu \mathrm{mhos} / \mathrm{cm})$ and for water that may adversely affect many crops and require careful management practices is 1500 to 3000 $\mu \mathrm{mhos} / \mathrm{cm}$ (Follett and Soltanpour, 1985). Specific conductance of the ground water at Bowman ranges from 1350 to $7750 \mu \mathrm{mhos} / \mathrm{cm}$. Therefore, using ground water for irrigation may adversely affect most crops, based on specific conductance. The irrigation pathway to agricultural crops is not a current pathway in the Bowman area. Agricultural practices in the area include dry land farming (wheat, barely, and oats) and raising cattle. Irrigation is not known to be used in the area. Furthermore, the yield of the shallow ground water system in the site vicinity would limit its potential use for crop irrigation.

Table 7.2 compares potentially phytotoxic tissue concentrations in plants to estimated tissue concentrations in plants irrigated with contaminated ground water. Concentrations of the contaminants in tissue at harvestable maturity were estimated using soil-to-plant bioconcentration factors (BCF). No sitespecific soil data or water-to-plant BCFs are available. Therefore, soil concentrations in the saturated zone were estimated by multiplying the ground water concentration by a literature-derived, soil-water distribution coefficient, $\mathrm{Kd}$. Several uncertainties are associated with the use of nonsite-specific Kd values and estimated soil-to-plant concentration factors. The estimated plant tissue concentrations could over- or underestimate actual tissue concentrations. This methodology is described in detail in the literature (Baes et al., 1984) and will not be presented here.

Few data are available relate tissue concentrations to phytotoxicity. Those phytotoxic concentrations reported are not representative of very sensitive or highly tolerant plant species (Kabata-Pendias and Pendias, 1992). As a screening level assessment, comparison shows that no constituents in ground water would reach or exceed phytotoxic levels in plant tissue. Because several water quality parameters do not have corresponding information on phytotoxicity levels (for comparison), results for these contaminants are inconclusive. This assessment may apply to the potential future use scenario of irrigating a domestic garden with ground water.

Bioaccumulation is the net accumulation by organisms from all routes of exposure, including diet. Bioaccumulation in terrestrial organisms is a function of the levels of contaminants ingested through other plants or animals. Foraging wildlife can be exposed indirectly to contaminants in ground water by ingesting plants that have bioaccumulated certain contaminants. In small contaminated areas, the amount of food in the diet usually exceeds the impacted food and bioaccumulation is not a concern. Therefore, the potential for bioaccumulation in terrestrial organisms is a relatively small concern. 
Table 7.2 Comparison of estimated plant concentrations to phytotoxic concentrations near the Bowman, North Dakota, site

\begin{tabular}{|c|c|c|c|c|c|c|c|c|}
\hline $\begin{array}{l}\text { Constituents } \\
\text { above back- } \\
\text { ground in } \\
\text { shallow ground } \\
\text { water } \\
\end{array}$ & $\begin{array}{l}\text { UCL } \\
\text { in ground water } \\
\text { (mg/L) }\end{array}$ & $\begin{array}{c}\mathrm{Kd} \\
(\mathrm{L} / \mathbf{k g})\end{array}$ & $\begin{array}{c}\text { Estimated soil } \\
\text { concentrationa } \\
\text { (mg/kg DW) }\end{array}$ & $\begin{array}{r}\begin{array}{r}\text { Soil } \\
\text { concentr }\end{array} \\
\mathrm{Bv} \\
\end{array}$ & $\begin{array}{l}\text { D-plant } \\
\text { tion factors } \\
\mathrm{Br}\end{array}$ & $\begin{array}{c}\text { Estimated } \\
\text { concentration } \\
\text { in vegetative } \\
\text { growth } \\
\text { (mg/kg DW) } \\
\end{array}$ & $\begin{array}{c}\text { Estimated } \\
\text { concentration } \\
\text { in fruits/ } \\
\text { tubers } \\
\text { (mg/kg DW) } \\
\end{array}$ & $\begin{array}{c}\text { Approximate } \\
\text { concentration } \\
\text { in mature leaf } \\
\text { tissue that is } \\
\text { toxic } \\
\text { (mg/kg DW) }\end{array}$ \\
\hline Arsenic & 0.007 & 5.9 & 0.04 & 0.04 & 0.006 & 0.002 & 0.0002 & $5-20$ \\
\hline Boron & 1.3 & 0.19 & 0.25 & 4 & 2 & 1.0 & 0.5 & $50-200$ \\
\hline Bromide & ND & NA & NC & NA & NA & NC & NC & NA \\
\hline Calcium & 340 & 0 & NC & 3.5 & 0.35 & NC & NC & NA \\
\hline Chloride & 61 & NA & NC & 70 & 70 & NC & NC & $50-500$ \\
\hline Fluoride & 0.95 & 0 & NC & 0.06 & 0.006 & NC & NC & NA \\
\hline Magnesium & 580 & 1400 & 812,000 & 1.0 & 0.55 & 810,000 & 446,600 & $10-50$ \\
\hline Molybdenum & 0.64 & 40 & 25.6 & 0.25 & 0.06 & 6.4 & 1.5 & NA \\
\hline Nitrate & 110 & 0 & NC & NA & NA & NC & NC & NA \\
\hline Phosphate & 1.1 & 50 & 55 & NA & NA & NC & NC & NA \\
\hline Potassium & 39 & 0 & NC & 1.0 & 0.55 & NC & NC & NA \\
\hline Radium-226 & $3.0(\mathrm{pCi} /)$ & 24 & 72 & 0.015 & 0.0015 & 1.1 & 0.11 & $5-30$ \\
\hline Selenium & 0.12 & 14.9 & 1.79 & 0.025 & 0.025 & 0.003 & 0.003 & $5-30$ \\
\hline Silver & 0.03 & 4 & 0.12 & 0.40 & 0.10 & 0.05 & 0.01 & $5-10$ \\
\hline Sodium & 1550 & 0 & NC & 0.075 & 0.055 & NC & NC & NA \\
\hline Strontium & 3.5 & 100 & 350 & 2.5 & 0.25 & 875 & 87.5 & NA \\
\hline Sulfate $^{\theta}$ & 5780 & 0 & NC & 0.5 & 0.5 & NC & NC & NA \\
\hline Uranium & 0.106 & 50 & 270 & 0.0085 & 0.004 & 2.29 & 1.08 & NA \\
\hline Magnesium & 298 & 1400 & 417,000 & 1.0 & 0.55 & 417,000 & 229,500 & NA \\
\hline Vanadium & 0.100 & 100 & 10 & 0.0055 & 0.003 & 0.055 & 0.03 & $5-10$ \\
\hline Zinc & 0.05 & 13 & 0.65 & 1.5 & 0.9 & 0.98 & 0.59 & $100-400$ \\
\hline
\end{tabular}

${ }^{a} \mathrm{Kd} \times$ UCL $=$ estimated soil concentration.

Estimated soil concentration multiplied by Bv.

Estimated soil concentration multiplied by $\mathrm{Br}$.

${ }^{d}$ Concentrations are not presented for very sensitive or for highly tolerant plant species (Kabata-Pendias and Pendias, 1992).

${ }^{\circ} \mathrm{Bv}$ and $\mathrm{Br}$ factors evailable for elemental sulfur only; thus, these factors were reduced by a factor of 3 for sulfate.

Kd - soil-water distribution coefficient; from PNL (1989).

BV - soil-to-plant elemental transfer factor for vegetative portions of food crops and feed plants (Baes et al., 1984).

$\mathrm{Br}$ - soil-to-plant elemental transfer factor for nonvegetative portions (e.g., fruits, tubers), of food crops and feed plants (Baes et al., 1984).

DW - dry weight.

NA - not available.

NC - value cannot be calculated because Kd is zero.

Note: Fow phytotoxicity data are available. 
Biomagnification is a more severe situation in which the concentration of a constituent increases in higher levels of the food chain because contaminant concentrations are accumulated through each successive trophic level. Only a limited number of constituents are known to magnify in the food chain. Based on available information and the potential for the types of contaminants detected at the Bowman site to represent a concern, food-chain transfer is very low.

\subsection{SEDIMENTS}

One round of sediment samples was collected in the Bowman site vicinity. Three sample locations were monitored. Sediment samples were analyzed for cadmium, chromium, lead, molybdenum, selenium, and uranium. Sample location 601 showed the highest metal concentrations. Location 601 is adjacent to the western site boundary and within the area of known soil contamination (Figure 2.2). Surface runoff from precipitation accumulates in this low-lying area west of the site and metals could accumulate in soils here. At the time of sampling there was no standing surface water and the sediment sample was actually a dry soil sample. Results from the other three sampling locations were substantially lower. Sediment sampling locations were limited in scope and like surface water data, were not effective in estimating potential impacts from the site. Table 7.3 compares available sediment quality guidelines with sediment data.

\subsection{UNCERTAINTIES OF THE ECOLOGICAL RISK ASSESSMENT}

The qualitative evaluation of potential ecological risks presented here is a screening level assessment of the risks associated with potential exposure of plants and animals to contaminated ground water, surface water, and sediment at the Bowman site. Sources of uncertainty in any ecological assessment arise from the monitoring data, exposure assessments, toxicological information, and the inherent complexities of the ecosystem. In addition, methods of predicting nonchemical stresses (e.g., drought), biotic interactions, behavior patterns, biological variability (i.e., differences in physical conditions, nutrient availability), and resiliency and recovery capacities are often unavailable.

\subsection{SUMMARY}

There are no current pathways for contaminated ground water to terrestrial, aquatic, or livestock receptors. Therefore, no current ecological risk exists at the Bowman site. As a potential future exposure scenario, a ground water-fed pond was considered and on-site ground water quality was compared to available surface water quality criteria. This comparison showed that ground water would be acceptable for livestock watering but would not be acceptable as irrigation water. Because agricultural crops are not irrigated with ground water in the site vicinity, the irrigation pathway would only be a concern for a small domestic garden. This ground water could threaten aquatic organisms. 
Table 7.3 Comparison of metals in sediments near Bowman, North Dakota, site with sediment quality values

\begin{tabular}{|c|c|c|c|c|c|}
\hline \multirow{2}{*}{$\begin{array}{c}\text { Constituents } \\
\text { monitored in } \\
\text { sediments }\end{array}$} & \multirow[b]{2}{*}{ Sample location } & \multirow{2}{*}{$\begin{array}{c}\text { Concentration } \\
\text { detected }\end{array}$} & \multirow[b]{2}{*}{ Detection limit } & \multicolumn{2}{|c|}{ NOAA guidelines } \\
\hline & & & & ER-L & ER-M \\
\hline \multirow[t]{4}{*}{ Cadmium } & 594 & 0.4 & 0.1 & 5 & 9 \\
\hline & 601 & 1.0 & & & \\
\hline & 602 & 0.4 & & & \\
\hline & 602 & 1.4 & & & \\
\hline \multirow[t]{4}{*}{ Chromium } & 594 & 12 & 1.0 & 80 & 145 \\
\hline & 601 & 17 & & & \\
\hline & 602 & 15 & & & \\
\hline & 602 & 12 & & & \\
\hline \multirow[t]{4}{*}{ Lead } & 594 & 10 & 0.3 & 35 & 110 \\
\hline & 601 & 22 & & & \\
\hline & 602 & 16 & & & \\
\hline & 602 & 10 & & & \\
\hline \multirow[t]{4}{*}{ Molybdenum } & 594 & 1 & 1.0 & NA & NA \\
\hline & 601 & 134 & & & \\
\hline & 602 & 1 & & & \\
\hline & 602 & 1 & & & \\
\hline \multirow[t]{4}{*}{ Selenium } & 594 & $<0.5$ & 0.5 & NA & NA \\
\hline & 601 & 10 & & & \\
\hline & 602 & $<0.5$ & & & \\
\hline & 602 & $<0.5$ & & & \\
\hline \multirow[t]{4}{*}{ Uranium } & 594 & 2.1 & 0.1 & NA & NA \\
\hline & 601 & 320 & & & \\
\hline & 602 & 3.3 & & & \\
\hline & 602 & 3.8 & & & \\
\hline
\end{tabular}

NA - not available.

ER-L - effects range-low.

ER-M - effects range-medium. 
Because there are no current or future potential pathways to aquatic organisms, this pathway is not considered an ecological risk for this site.

The comparative evaluation of potential exposure by biota to contaminants in ground water provides some insight into the potential for adverse impacts to biological receptors. Additional site-specific monitoring would be necessary to quantify the actual risks. 


\subsection{INTERPRETATION AND RECOMMENDATIONS}

\subsection{RISK SUMMARY}

The UMTRCA (42 USC $\$ 7901$ et seq.) requires the UMTRA Project to protect public health and the environment from radiological and nonradiological hazards associated with the former uranium mill sites. This baseline risk assessment was conducted to evaluate the presence of these hazards at the Bowman site.

Several constituents in background ground water are at levels above health advisories and/or EPA MCLs. The toxicity potential of constituents in background ground water, independent of site-related contamination, was not quantified. However, it should be noted that some risk may be associated with ingesting background shallow ground water in the Bowman site vicinity prior to any incremental risks contributed by site-related contaminants.

There are no current exposure pathways to contaminated ground water at the site. Therefore, no current risks exist for humans. Contamination was not detected in the nearest domestic wells adjacent to the site. Furthermore, the nearest residence uses bottled water for drinking.

Potential future risks from drinking contaminated ground water was examined. The evaluation was based on current water quality beneath the site.

Constituent levels are expected to reduce in time because of the removal of soil contamination and should represent a conservative estimate. Of the site-related contaminants of potential concern for human health, molybdenum, sodium, and sulfate could cause mild toxic effects with long-term ingestion. Chemical interactions both with site-related contaminants and background constituents in ground water are possible; however, the potential for increased adverse health effects from background ground water was not quantified.

Irrigating garden produce or watering livestock with contaminated shallow ground water is not expected to threaten human health. Adverse health effects would not be expected following ingestion of milk or meat from animals grazed downgradient of the site or watered with shallow ground water in the area. Ingesting garden produce watered with contaminated ground water would not cause adverse health effects.

Natural uranium has not been demonstrated to cause cancer in humans or animals following ingestion. However, all uranium isotopes are radioactive and, as such, are considered potential carcinogens. The estimated carcinogenic risk of ingesting uranium in ground water includes dose estimates of all of the radioactive progeny of uranium. The total excess lifetime cancer risk is three times the EPA upper acceptable limit of $10^{-4}$. Most excess cancer risk is from uranium itself, where 25 percent of the potential exposures to uranium fall above the $10^{-4}$ limit. 
No current exposure pathways to biota exist at the site. Therefore, no current risks to plants, wildlife, or livestock exist. The evaluation of potential future exposure to contaminated ground water shows the contaminated ground water at the site would not likely impact ecological receptors and could be used as a continuous water source for livestock. The sulfate and TDS levels, however, preclude its use by lactating or pregnant animals. The ground water is not recommended for irrigating crops or garden produce because of potential adverse impacts to the plants. There are no apparent potential threats to wildlife, although information for making this assessment is limited. Current or potential future exposure to aquatic life is not expected so aquatic organisms are not at risk.

\subsection{LIMITATIONS OF THIS RISK ASSESSMENT}

\section{Human health risks}

The following limitations to this evaluation of health risks should be noted:

- This document evaluates risks related to inorganic contaminants in ground water. The presence of organics was not investigated.

- The results presented in this document are based on filtered $(0.45-\mu \mathrm{m}$ filter) water samples. The effect of filtration differs for different elements. Filtered samples can have somewhat lower concentrations than unfiltered samples for some constituents. Constituents in suspension may be lost with filtration but could still produce toxic effects if ingested and broken down in the acidic environment of the stomach. However, none of the unfiltered data suggest that any contaminants of potential concern were overlooked by using filtered data.

- The toxicity of any contaminant varies from individual to individual. Using probability distributions of potential exposure and presenting ranges of exposures that correspond with specific potential toxic effects indicates the types of health impacts that may occur. However, this does not define the likelihood of individual responses to toxicity. It is not possible to account for all sources of toxic response variabilities and still present useful and meaningful analyses. However, specific subpopulations known to be more sensitive to the toxic effects of given constituents are noted.

- To assess toxicity, standardized reference values developed by agencies such as the EPA are used to determine plant uptake, tissue concentrations in livestock, and toxic effects in humans. These reference values themselves have limitations, including the following:

- Toxicity, uptake, and bioconcentration data are not available for all constituents elevated above background at the site. 
- In some cases, data obtained from laboratory animal testing at exposure doses different from those expected at the site were used to determine toxicity. The relationship between dose and response is not always linear and humans do not always exhibit the same responses as animals.

- Data used to determine toxicity generally are based on exposure to only the contaminant of potential concern. In reality, exposures generally occur simultaneously to several chemicals. The interactive effects of multiple constituents and the impact of these interactions on expected toxicity generally cannot be assessed accurately from existing data.

- Considerable effort has been directed at determining plume location and placing monitor wells in locations that capture maximal contamination. However, variabilities in physical systems and models used to determine the location of the contaminant zones still could result in well placements that do not measure the highest contaminant concentrations or determine the fullest extent of the contamination.

- Variability can be introduced through sampling and analytical processes. However, the data at UMTRA Project sites were collected over many ears and subjected to rigorous quality assurance procedures. The use of multiple samples introduces high confidence in the reliability and validity of these data.

- The drinking water pathway is considered the major determinant of exposure in this assessment. Although other pathways were screened and determined not to contribute significantly to the total exposure, the additivity of exposure from these pathways should be noted. Other pathways did not increase expected exposures significantly enough to alter predicted toxicities.

By presenting ranges of toxic effects, summaries of available data on health effects and interactions, and outlines of potential limitations, this document provides a reasonable interpretation of potential health risks associated with ground water contamination at this site. This assessment presents both contamination and risk as accurately as possible, based on available data, and conveys areas of uncertainty.

\section{Ecological risk}

Limitations for the ecological risk assessment include the following:

- Only a small amount of ecological data were collected during this screening.

- Little is known about site-specific intake rates for wildlife or amounts of contaminants taken up by plants. General literature values were used in many cases. 
- Only limited ecotoxicological reference data are available.

- Considerable uncertainty is associated with the toxicity of mixtures of contaminants.

\subsection{GROUND WATER CRITERIA}

In 1983, the EPA established health and environmental protection standards for the UMTRA Project. In 1987 the EPA proposed revised ground water standards in the UMTRCA. The UMTRA Project is required to adhere to the 1987 proposed ground water standards until final standards are published. The UMTRCA ground water standards consist of 1) ground water protection standards to evaluate disposal cell performance, and 2) ground water cleanup standards for existing contamination at processing sites (Table 8.1). Because MCLs are not established for all contaminants, the proposed standards require the contaminants that do not have MCLs to meet background levels.

While the UMTRCA standards apply only to the UMTRA Project, the EPA has also published drinking water health advisory levels for both long- and shortterm exposures. These advisories are shown in Table 8.1.

Contaminants of potential concern at the site, arsenic, molybdenum, selenium, and vanadium, exceed the criteria in on-site monitor wells. Background concentrations of molybdenum and selenium also exceed these criteria. Other constituents, not above background on-site, but present in background above these criteria are antimony, cadmium, and lead. Chromium and nickel, are present in background but do not exceed these criteria. Aluminum and copper are present in background but there are no criteria with which to evaluate them. Overall, several metals in background ground water exceed the health advisory and/or EPA MCLs, suggesting potential risk from the ingestion of ground water regardless of the incremental site-related impacts to ground water at the site.

\subsection{RISK MITIGATION MEASURES/INSTITUTIONAL CONTROLS}

No current potential human health risk exists from exposure to contaminated ground water at the Bowman site because no exposure pathways are complete. However, because shallow ground water is impacted below the former lignite ashing site, a future potential risk exists if contaminated ground water were used on a long-term basis. The city of Bowman is 7 mi east of the processing site in Bowman County, North Dakota; one residence is adjacent to the site. The affected ground water is not currently used as a drinking water supply but it may be used for stock watering, washing, and gardening. This section presents ways to restrict access to contaminated ground water, if needed, in the future.

The preamble to the proposed ground water standards for the UMTRA Project defines institutional controls as mechanisms that can be effectively used to protect human health and the environment by controlling access to 
Table 8.1 Concentration limits

\begin{tabular}{|c|c|c|c|}
\hline Constituent & $\begin{array}{c}\text { UMTRCA MCL } \\
(\mathrm{mg} / \mathrm{L})^{\mathrm{a}}\end{array}$ & $\begin{array}{c}\text { EPA health advisories } \\
\text { 10-kg child, 10-day } \\
\text { (mg/L) }\end{array}$ & $\begin{array}{c}\text { EPA health advisories } \\
\begin{array}{c}70-\mathrm{kg} \text { adult, lifetime } \\
(\mathrm{mg} / \mathrm{L})^{\mathrm{b}}\end{array}\end{array}$ \\
\hline \multicolumn{4}{|l|}{ Chemicals (inorganic) } \\
\hline Antimony & - & 0.015 & 0.003 \\
\hline Arsenic & 0.05 & - & - \\
\hline Barium & 1.0 & - & 2 \\
\hline Boron & - & 0.9 & 0.6 \\
\hline Cadmium & 0.01 & 0.04 & 0.005 \\
\hline Chromium & 0.05 & 1.0 & 0.1 \\
\hline Cobalt & - & - & - \\
\hline Copper & - & - & - \\
\hline Fluoride & - & - & - \\
\hline Iron & - & - & - \\
\hline Lead & 0.05 & - & 0.015 \\
\hline Manganese & - & - & - \\
\hline Mercury & 0.002 & - & - \\
\hline Molybdenum & 0.1 & 0.08 & 0.04 \\
\hline Nickel & - & 1.0 & 0.1 \\
\hline Nitrate & $44^{c}$ & $44^{d}$ & - \\
\hline Selenium & 0.01 & - & - \\
\hline Silver & 0.05 & 0.2 & 0.1 \\
\hline Strontium & - & 25 & 17 \\
\hline Sulfate & - & - & - \\
\hline Thallium & - & 0.007 & 0.0004 \\
\hline Vanadium & - & 0.08 & 0.02 \\
\hline Zinc & - & 6.0 & 2 \\
\hline \multicolumn{4}{|l|}{ Radionuclides } \\
\hline Lead-210 & - & - & - \\
\hline Polonium-210 & - & - & - \\
\hline Radium-226/-228 & $5 \mathrm{pCi} / \mathrm{L}$ & - & - \\
\hline Thorium-230 & - & - & - \\
\hline $\begin{array}{l}\text { Uranium } \\
\text { (U-234/-238) }\end{array}$ & $\begin{array}{c}30 \mathrm{pCi} / \mathrm{L} \\
(0.044 \mathrm{mg} / \mathrm{L})\end{array}$ & $0.03^{d, e}$ & $0.1^{d}$ \\
\hline
\end{tabular}

aDash indicates no MCLs available.

b Dash indicates no RfD available with which to calculate a health-based concentration.

CEqual to $10 \mathrm{mg} / \mathrm{L}$ nitrate as nitrogen.

dProposed values; under review.

Exceeded in plume well 520 and in background. 
contaminated ground water (52 FR 36000). Although the preamble refers to long-term institutional controls (e.g., up to 100 years during natural flushing), this concept could also be applied to short-term or interim restrictions of access to ground water.

The state of North Dakota Ground Water Protection Act directs the state health department to conduct ground water quality monitoring in cooperation with the state engineer and other state agencies. Based on monitoring results, the department must implement or require mitigation activities or remedial action to prevent future ground water contamination. The health department also is responsible for protecting the health of the citizens of North Dakota; with the authority to advise people when their wells are contaminated. However, it cannot restrict or notate deeds (Glatt, 1994).

Water permits are required for all wells except domestic wells and livestock watering wells that draw less than 12.5 acre feet per year. The state engineer's office issues permits for all other wells. These permits ensure that wells are constructed properly and that the quantity of water withdrawn is acceptable. Although the state engineer may evaluate a permitted well based on water quality, water quality is not part of the permitting evaluation. This office does not grant permits for domestic and agricultural wells (Linden, 1994).

The Southwest District Health Unit in Dickinson, North Dakota has the most access to existing and new ground water well users in the state. The Health Unit has jurisdiction over eight counties, including Bowman County; this office maintains county maps that identify landowners and notifies county residents of health advisories (Herring, 1994).

\section{$8.5 \quad$ FUTURE SITE ACTIVITIES}

Most site characterization activities conducted at the Bowman site to date provided preliminary site characterization information for designing and implementing a surface remediation plan under the UMTRA Surface Project. Additional site characterization activities are planned under the UMTRA Ground Water Project. Results of this baseline risk assessment will be used to plan further site activities for the Ground Water Project.

\subsection{RECOMMENDATIONS}

In general, the proposed ground water standards (MCLs or background concentrations) are sufficient to protect human health and the environment. However, in some cases, a risk assessment may identify site-specific factors that suggest these standards are too restrictive or not restrictive enough. When standards are too restrictive, there may be no potential for exposure and a less restrictive alternate concentration limit $(A C L)$ may be sought. In other cases, the standards may not be sufficiently protective le.g., if there are many contaminants near the MCL with additive or synergistic adverse health effects). 
Many inorganic constituents were present in both on-site and background ground water. Some of these constituents are site-related due to their above background levels in on-site monitor wells. Specific contaminants were selected from this group as contaminants of potential concern for human health because they could adversely affect human health with chronic exposure. Abovebackground constituents that were screened from the list of contaminants with health concerns should qualify for ACLs. Exposures to these constituents were determined to be at levels within nutritional or dietary ranges or at levels not associated with any adverse health effects.

In the quantitative evaluation of the contaminants of potential concern for human health, levels of selenium and vanadium were determined to be below adverse effects levels; no potential risks were identified. These constituents should also qualify for ACLs. Chronic ingestion of the remaining noncarcinogenic contaminants of potential concern (molybdenum, sodium, and sulfate) was determined to present a potential risk of mild toxicity. The carcinogenic contaminants of potential concern (arsenic and uranium) present cancer risks above the acceptable EPA criteria. These potential impacts identified for site-related contaminants overlap the potential risks associated with naturally occurring constituents in background ground water. Risks from background ground water were not quantified in this risk assessment.

No current exposure pathways to biota exist at the site. Therefore, no current risks to plants, wildlife, or livestock exist. The evaluation of the potential future exposure to contaminated ground water shows the contaminated ground water at the site would not likely impact ecological receptors and could be used as a continuous water source for livestock but not for irrigating crops or garden produce. There is potential risk for adverse impacts to plants. Because there are no current or future potential exposure pathways to aquatic organisms, aquatic organisms are not at risk. 


\subsection{LIST OF CONTRIBUTORS}

The following individuals contributed to the preparation of this report.

\begin{tabular}{ll}
\hline Name & Contribution \\
\hline M. Day & Primary author and document coordinator \\
J. Carman/D. Hydenburg & Hydrogeology \\
A. Groffman & Geochemistry \\
M. Gawthrop-Cooper & Institutional controls \\
M. Day & Toxicology \\
L. Sanchez, L. Keith & Word processing \\
E. Bond & Graphic design \\
J. Torline & Technical editing, document publication coordination \\
\hline
\end{tabular}




\subsection{REFERENCES}

Aiyar, A. S., and A. Sreenivasan, 1961. Proceedings from the Society of Experimental Biology and Medicine, Vol. 107, pp. 914-916.

Alexander et al. (F. W. Alexander, B. E. Clayton, and H. T. Delves), 1974. Q. J. Med., Vol. 53, pp. 89-111.

Allison et al. (J. D. Allison, D. S. Brown, and K. J. Novo-Gradac), 1991. MINEOA2/PRODEFA2, A Geochemical Assessment Model for Environmental Systems: Version 3.0 User's Manual, EPA/600/3-91/021, Environmental Research Laboratory, Office of Research and Development, U.S. Environmental Protection Agency, Athens, Georgia.

Baes et al. (C. F. Baes III, R. D. Sharp, A. L. Sjoreen, and R. W. Shor), 1984. A Review and Analysis of Parameters for Assessing Transport of Environmentally Released Radionuclides Through Agriculture, ORNL-5786, prepared for Oak Ridge National Laboratory, Health and Safety Research Division, Oak Ridge, Tennessee.

Ballou et al. (J. E. Ballou, R. A. Gies, A. C. Case, D. L. Haggard, R. L. Buschbom, and J. L. Ryan), 1986. "Deposition and Early Disposition of Inhaled Uranium-233 Uranyl Nitrate and Uranium-232 Uranyl Nitrate in the Rat," in Health Physics, No. 51. pp. 755-772.

Bauer and Land, 1976. Map of the Bowman-Scranton Uranium Project, Bowman and Adams Counties, North Dakota.

Belehova, B. A., 1969. Scientific Transactions of the Irkutsk State Medical Institute, Vol. 96, pp. $20-23$ (in Russian).

Berlin, M., and B. Rudell, 1986. "Uranium," Handbook on the Toxicology of Metals, second edition, L. Friberg, G. F. Nordberg, and V. B. Vouk, eds., pp. 647-658, Elsevier Science Publishers, Amsterdam.

Bopp et al. (B. A. Bopp, R. C. Sanders, and J. W. Kesterson), 1982. Drug Metab. Rev., Vol. 13, pp. 271-318.

Brookins, D. G., 1988. Eh-pH Diagrams for Geochemistry, Springer-Verlag, N.Y., N.Y.

Buchet et al. (J. P. Buchet, R. Lauwerys, and H. Roels), 1981. "Urinary Excretion of Inorganic Arsenic and its Metabolites After Repeated Ingestion of Sodium Metaarsenite by Volunteers", in International Archives of Occupational and Environmental Health, No. 48, pp. 111-118. 
Buchet et al. (J. P. Buchet, H. Roels, and R. Lauwerys), 1980. "Repeated Surveillance of Exposure to Cadmium, Manganese, and Arsenic in School-Age Children Living in Rural, Urban, and Nonferrous Smelter Areas in Belgium," in Environmental Research, No. 22, pp. 95-108.

Byerrum et al. (R. U. Byerrum, R. E. Eckardt, L. L. Hopkins), 1974. Vanadium, National Academy of Sciences, Washington, D.C.

Byrne, A. R., and L. Kosta, 1978. Sci. Total Environ., Vol. 10, pp. 17-30.

Calabrese, E. J., and R. W. Tuthill, 1977. "Elevated Blood Pressure and High Sodium Levels in the Public Drinking Water," in Archives of Environmental Health, September/October 1977, pp. 200-202.

Carsen, T. L., 1992. "Toxic Minerals, Chemicals, Plants, and Gases," Diseases of Swine, seventh edition, lowa State University Press, Ames, lowa.

Carson et al. (B. L. Carson, H. V. Ellis III, and J. L. McCann), 1986. Toxicology and Biological Monitoring of Metals in Humans, Lewis Publishers, Inc., New York, New York, pp. 226-230.

Casarett, L. J., and J. Doull, 1991. Toxicology: The Basic Science of Poisons, fourth edition, Pergamon Press, New York, New York.

CDH (Colorado Department of Health), 1991. Basic Standards and Methodologies for Surface Water, 3.1.0., Water Quality Control Commission, Denver, Colorado.

Cothern, C. R., and W. L. Lappenbusch, 1983. "Occurrence of Uranium in Drinking Water in the United States," in Health Physics, No. 45, pp. 89-99.

Crecelius, E. A., 1977. "Changes in the Chemical Speciation of Arsenic following Ingestion by Man," in Environmental Health Perspective, No. 19, pp. 147-150.

Cummins, L. M., and E. T. Kimura, 1971. Toxicological Applied Pharmacology, Vol. 20, pp. 89-96.

Curran et al. (G. L. Curran, D. L. Azarnoff, and R. E. Bolinger), 1959. Journal of Clinical . Investigation, Vol. 38, pp. 1251-1261.

Denson et al. (N. M. Denson, G. O. Bachman, and H. D. Zeller), 1959. "Uranium-Bearing Lignite in Northwestern South Dakota and Adjacent States," U.S. Geological Survey Bulletin 1055-B, pp. 11-57.

DHHS (U.S. Department of Health and Human Services), 1993. "Toxicological Profile for Arsenic," prepared by Syracuse Research Corporation for the U.S. Department of Health and Human Services, Public Health Service, Agency for Toxic Substances and Disease Registry, Atlanta, Georgia. 
DHHS (U.S. Department of Health and Human Services), 1989. "Toxicological Profile for Selenium," prepared by Clement Associates for the U.S. Department of Health and Human Services.

Dimond et al. (E. G. Dimond, J. Caravaca, and A. Benchimol), 1963. "Vanadium: Excretion, Toxicity, Lipid Effect in Man," in American Journal of Clinical Nutrition, Vol. 12, pp. 49-53.

DOE (U.S. Department of Energy), 1994. Programmatic Environmental Impact Statement for the Uranium Mill Tailings Remedial Action Ground Water Project, DOE/EIS0198, Rev. 3, draft, April 1994, prepared by the U.S. Department of Energy, UMTRA Project Office, Albuquerque Operations Office, Albuquerque, New Mexico.

DOE (U.S. Department of Energy), 1993. Environmental Assessment of Remedial Action at the Inactive Uraniferous Lignite Ashing Sites at Belfield and Bowman, North Dakota, DOE/EA-0326, September 1993, prepared by the U.S. Department of Energy, UMTRA Project Office, Albuquerque Operations Office, Albuquerque, New Mexico.

DOE (U.S. Department of Energy), 1991. Investigation of a Natural Geochemical Barrier, UMTRA-DOE/AL-400666.0000, February 1991, prepared by the U.S.

Department of Energy, UMTRA Project Office, Albuquerque Operations Office, Albuquerque, New Mexico.

DOE (U.S. Department of Energy), 1990. Remedial Action Plan for Stabilization of the Inactive Uraniferous Lignite Ashing Sites at Belfield and Bowman, North Dakota, final, UMTRA-DOE/AL-050522.0000, Volume 1, prepared by the U.S. Department of Energy, UMTRA Project Office, Albuquerque Operations Office, Albuquerque, New Mexico.

Duel, M., and C. S. Annell, 1956. "Occurrence of Minor Elements in Ash of Low-Rank Coal From Texas, Colorado, North Dakota and South Dakota," U.S. Geological Survey Bulletin 1036-H, pp. 155-172.

Eisler, R., 1990. Boron Hazards to Fish, Wildlife, and Invertebrates: A Synoptic Review, U.S. Fish and Wildlife Service, Contaminant Hazard Reviews, Report 20, Laurel, Maryland, U.S. Department of the Interior, Washington, D.C.

Eisler, R., 1989. Molybdenum Hazards to Fish, Wildlife, and Invertebrates: A Synoptic Review, U.S. Fish and Wildlife Service, Contaminant Hazard Reviews, Report 19, Laurel, Maryland, U.S. Department of the Interior, Washington, D.C.

EPA (U.S. Environmental Protection Agency), 1994a. Integrated Risk Information System (IRIS), database, Office of Research and Development, Washington, D.C. 
EPA (U.S. Environmental Protection Agency), 1994b. Health Effects Assessment Summary Tables, OHEA ECAO-CIN-821, March 1992, Office of Research and Development, Office of Emergency and Remedial Response, Washington, D.C.

EPA (U.S. Environmental Protection Agency), 1992. Drinking Water Criteria Document for Sulfate, Health and Environmental Criteria Division, Office of Science and Technology, U.S. Environmental Protection Agency, Washington, D.C.

EPA (U.S. Environmental Protection Agency), 1991. Human Health Evaluation Manual, supplemental guidance, "Standard Default Exposure Factors," U.S. Environmental Protection Agency, Washington, D.C.

EPA (U.S. Environmental Protection Agency), 1989a. Risk Assessment Guidance for Superfund, Vol. I, Human Health Evaluation Manual, EPA/540/1-89/002, Office of Emergency and Remedial Response, Washington, D.C.

EPA (U.S. Environmental Protection Agency), 1989b. Risk Assessment Guidance for Superfund, Vol. II, Environmental Evaluation Manual, EPA/540/1-89/001, Office of Emergency and Remedial Response, Washington, D.C.

EPA (U.S. Environmental Protection Agency), 1987. Ambient Aquatic Life Water Quality Criteria for Silver, draft, Office of Research and Development, Environmental Research Laboratories, Duluth, Minnesota, and Narragansett, Rhode Island.

EPA (U.S. Environmental Protection Agency), 1986. "Quality Criteria for Water," EPA 440/5-86-001, Office of Regulations and Standards, Washington, D.C.

EPA (U.S. Environmental Protection Agency), 1984. Health Assessment Document: Inorganic Arsenic, U.S. Environmental Protection Agency, Washington, D.C.

EPA (U.S. Environmental Protection Agency), 1980. Ambient Water Quality Criteria for Selenium, EPA 440/5-80-070, NTIS PB 81-117814, prepared by the Office of Health and Environmental Assessment, Environmental Criteria and Assessment Office, Cincinnati, Ohio, for the Office of Water Quality Planning Standards, Washington, D.C.

EPA (U.S. Environmental Protection Agency), 1977. Scientific and Technical Assessment Report on Vanadium, EPA-600-6-77-002, U.S. Environmental Protection Agency, Washington, D.C.

FBDU (Ford, Bacon and Davis Utah, Inc.), 1981. Engineering Assessment of Inactive Uranium Mill Tailings, Bowman Site, Bowman, North Dakota, DOE/UMT-0121, Salt Lake City, Utah.

Ferm, V. H., 1971. "The Teratogenic Profile of Sodium Arsenate in the Golden Hamster," in Archives of Environmental Health, No. 22, pp. 557-560. 
Fisenne et al. (I. M. Fisenne, P. M. Perry, and N. H. Harley), 1988. "Uranium in Humans," in Radiation Protection Dosimetry, No. 24, pp. 127-131.

Flanagan et al. (P. R. Flanagan, J. S. McLellan, J. Haist, M. G. Cherian, M. J. Chamberlain, and L. S. Valberg), 1978. Gastroenterology, Vol. 74, pp. 841-846.

Follett, R. H., and P. N. Soltanpour, 1985. "Irrigation Water Quality Criteria," Colorado State University Extension Service publication number 506.

Freis, E. D., 1976. "Salt, Volume and the Prevention of Hypertension," in Circulation, Vol. 53, No. 4, pp. 589-595.

Friberg et al. (L. Friberg, G. F. Nordberg, and V. B. Vouk), 1986. Handbook on the Toxicology of Metals, Volume II: Specific Metals, second edition, Elsevier, New York, New York.

Fulton, C. S., 1989. "The Hydrologic, Geologic and Geochemical Factors Affecting the Distribution of Sodium in Lignite in the Underwood Lignite Field in West Central North Dakota," unpublished doctoral dissertation, University of Kentucky.

Fulton, C. S., and M. L. Jones, 1986. "Geological, Geochemical, and Hydrological Factors Affecting the Distribution of Sodium in Lignite in West-Central North Dakota," Thirteenth Biennial Lignite Symposium: Technology and Utilization of Low-Rank Coals, Bismarck, North Dakota, pp. 559-566.

Glatt, D., 1994. State Department of Health, Bismarck, North Dakota, personal communication with Malu Gawthrop-Cooper, Jacobs Engineering Group Inc., UPDCC File Location No. 21.19.7, Albuquerque, New Mexico, May 25, 1994.

Gosselin et al. (R. E. Gosselin, H. C. Hodge, and R. P. Smith), 1976. Clinical Toxicology of Commercial Products, fourth edition, Williams and Wilkins, Baltimore, Maryland.

Hadjimarkos, D. M., 1968. Adv. Oral Biol., Vol 3, pp. 253-292.

Hadjimarkos, D. M., 1966. Nature, Vol. 209, p. 1137.

Harris et al. (W. R. Harris, S. B. Friedman, and D. Silberman), 1984. Journal of Inorganic Biochemistry, Vol. 20, pp. 157-169.

Herring, R., 1994. Southwest District Health Unit, Dickinson, North Dakota, personal communication with Malu Gawthrop-Cooper, Jacobs Engineering Group Inc., UPDCC File Location No. 21.19.7, Albuquerque, New Mexico, May 25,1994.

Hood, R. D., 1972. "Effects of Sodium Arsenite on Fetal Development," in Bulletin of Environmental Contamination and Toxicology, No. 7, p. 216. 
Houghton et al. (R. L. Houghton, G. S. Anderson, S. R. Hill, J. L. Burges, J. D. Wald, D. P. Patrick, R. L. Hall, and J. D. Unseth), 1987. "Prevention of Groundwater Quality Degradation During Reclamation of a Uraniferous Lignite Mine, North Dakota," in Proceedings of the Fourth Biennial Symposium on Surface Mining and Reclamation on the Great Plains, Reclamation Research Unit Report No. 8704.

Houghton et al. (R. L. Houghton, J. D. Wald, and G. Anderson), 1984. "Distribution and Hydrochemical Mobility of Radioactivity and Associated Constituents in the Coal-Bearing Fort Union Formation of Western North Dakota, "in 1984 Symposium of the Geology of Rocky Mountain Coal Proceedings: North Dakota Geological Society, Bismark, North Dakota, pp. 89-113.

Hsi, C. D., and D. Langmuir, 1985. "Adsorption of Uranyl Onto Ferric Oxyhydroxides: Application of the Surface Complexation Site-Binding Model," in Geochim. Cosmochim. Acta, Vol. 49, pp. 1931-1941.

ICRP (International Commission on Radiological Protection), 1960. ICRP Publ., 2.

Ishinishi et al. (N. Ishinishi, K. Tsuchiya, M. Vahter, and B. A. Fowler), 1986. "Arsenic," Handbook on the Toxicology of Metals, Volume II: Specific Metals, second edition, Elsevier Press Science Publishers B.V., Amsterdam.

Kabata-Pendias, A., and H. Pendias, 1992. Trace Elements in Soils and Plants, second edition, CRC Press, Boca Raton, Florida.

Karner et al. (F. R. Karner, H. H. Schobert, S. K. Falcone, and S. A. Vorres), 1986. "Elemental Distribution and Association with Inorganic and Organic Components in North Dakota Lignites," in Mineral Matter and Coal, American Chemical Society, Washington D.C., pp. 70-89.

Kent et al. (D. B. Kent, V. S. Tripathy, N. B. Ball, J. O. Leckie, and M. D. Siegel), 1988. Surface-Complexation Modeling of Radionuclide Adsorption in Subsurface Environments, NUREG/CR-4807/SAND86-7175, prepared by Sandia National Laboratories for the Division of High-Level Waste Management, Office of Nuclear Material Safety and Safeguards, U.S. Nuclear Regulatory Commission, Washington, D.C.

Lagerkvist et al. (B. Lagerkvist, G. F. Nordberg, and V. Vouk), 1986. "Vanadium," Handbook on the Toxicology of Metals, second edition, L. Friberg, G. F. Nordberg, and V. Vouk, eds., Elsevier Science Publishers, New York, New York.

Leach et al. (L. J. Leach, R. M. Gelein, B. J. Panner, C. L. Ylie, and C. C. Cox), 1984. The Acute Toxicity of the Hydrolysis Products of Uranium Hexafluoride (UF6) When Inhaled by the Rat and Guinea Pig, final report, ISS K/SUB-81-9039-3, National Technical Information Service, Springfield, Virginia. 
Leckie et al. (J. O. Leckie, M. M. Benjamin, K. Hayes, G. Kaufman, and S. Altman), 1980. Adsorption/Coprecipitation of Trace Elements From Water With Iron Oxide, EPRI CS-1513, EPRI, Palo Alto, California.

Linden, M., 1994. State Department of Health, Bismarck, North Dakota, personal communication with Malu Gawthrop-Cooper, Jacobs Engineering Group Inc., UPDCC File Location No. 21.19.7, Albuquerque, New Mexico, May 25, 1994.

Lindgren et al. (A. Lindgren, M. Vahter, and L. Dencker), 1982. "Autoradiographic Studies on the Distribution of Arsenic in Mice and Hamsters Administered ${ }^{74}$ As-arsenite or -arsenate," in Acta Pharmacology and Toxicology, No. 51, pp. 253-265.

Marafante, E., and M. Vahter, 1987. "Solubility, Retentions and Metabolism of Intratracheally and Orally Administered Inorganic Arsenic Compounds in Hamsters," in Environmental Research, No. 42, pp. 72-82.

Marcus, W. L., and A. S. Rispin, 1988. "Threshold Carcinogenicity Using Arsenic as an Example," in Advances in Environmental Toxicology, Volume XV, Risk Assessment and Risk Management of Industrial and Environmental Chemicals, C. R. Cothern, M. A. Mehlman, and W. L. Marcus, eds., Princeton Scientific Publishing Co., New Jersey, pp. 133-159.

Maynard, E. A., and H. C. Hodge, 1949. "Study of Toxicity of Various Uranium Compounds When Fed to Experimental Animals," in Pharmacology and Toxicology of Uranium Compounds, C. Voegtlin and H. C. Hodge, eds., National Nuclear Energy Services, Div. VI, McGraw Hill, New York, New York, Vol. 1, pp. 309-376.

Medinsky et al. (M. A. Medinsky, R. G. Cuddihy, and R. O. McClellan), 1981. J. Toxicol. Environ. Health, Vol. 8, pp. 917-928.

Meneely, G. R., and H. D. Battarbee, 1976. "Sodium and Potassium," in Nutrition Reviews, No. 8, pp. 225-235.

Millar et al. (K. R. Millar, M. A. Gardiner, and A. D. Sheppard), 1973. NZ J. Agric. Res., Vol. 16, pp. 115-127.

Miller, R. N., and P. H. Given, 1986. "The Association of Major, Minor and Trace Inorganic Elements with Lignite, 1, Experimental Approach and Study of a North Dakota Lignite," in Geochemica Cosmochemica Acta, Vol. 50, pp. 2033-2043.

Mohan et al. (M. S. Mohan, J. D. Ilger, and R. A. Zingarol, 1991. "Speciation of Uranium in a South Texas Lignite: Additional Evidence for a Mixed Mode of Occurrence," in Energy and Fue/s, American Chemical Society, 5, pp., 568-573. 
Moore et al. (G. W. Moore, R. E. Melin, and R. C. Kepferle), 1959. "Uranium-Bearing Lignite in Southwestern North Dakota," Uranium in Coal in the Western United States, Norman Denson, ed., United States Geological Survey, Bulletin 1055, pp. 147-166.

Morrison et al. (G. M. P. Morrison, G. E. Batley, and T. M. Florence), 1989. "Metal Speciation and Toxicity," in Chem. Br., No. 25, p. 791.

Nakashima, S., 1992. "Complexation and Reduction of Uranium by Lignite," in The Science of the Total Environment, 117/118, Elsevier Science Publishers B.V., Amsterdam, pp. 425-437.

National Research Council, 1989. Recommended Daily Allowances, tenth edition, National Academy Press, Washington, D.C.

National Research Council, 1980. Drinking Water and Health, Vol. 3, Safe Drinking Water Committee.

National Research Council, 1971. Nutrient Requirements of Dairy Cattle, Committee on Animal Nutrition, fourth edition, The National Academy of Science, Washington, D.C.

NCRP (National Council on Radiation Protection and Measurements), 1984. Exposures From the Uranium Series With Emphasis on Radon and Its Daughters, NCRP Report 77, Bethesda, Maryland.

NDSDH (North Dakota State Department of Health), 1991. "Standards of Water Quality for the State of North Dakota," Rule 33-16-02, North Dakota State Department of Health, February 1, 1991, Bismarck, North Dakota.

Nobel, E. A., 1972. "Metalliferous Lignite in North Dakota," in North Dakota Geological Survey, Miscellaneous Services 50, pp. 133-134.

Nordberg et al. (G. F. Nordberg, T. Kjellström, and M. Nordberg), 1985. Cadmium and Health: a Toxicological and Epidemiological Appraisal, L. Friberg, C. G. Elinder, T. Kjellström, and G. F. Nordberg, eds., CRC Press, Boca Raton, Florida.

Palisade Corporation, 1992. @RISK, Risk Analysis and Simulation Add-In for Lotus 1-2-3, Version 2.01, Newfield, New York.

Pennington, J. A., and J. W. Jones, 1987. "Molybdenum, Nickel, Cobalt, Vanadium, and Strontium in Total Diets," in Journal of the American Dietetic Association, Vol. 87. No. 12, December 1987, American Dietetic Association, Division of Nutrition and Division of Contaminants Chemistry, Center for Food Safety and Applied Nutrition, Food and Drug Administration, Washington, D.C.

Perry et al. (H. M. Perry, Jr., S. Teitlebaum, and P. L. Schwartz), 1955. Federal Proceedings, Vol. 14, pp. 113-114. 
Pershagen, G., and M. Vahter, 1979. Arsenic, Swedish Environmental Protection Board, Stockholm, Sweden.

PNL (Pacific Northwest Laboratory), 1989. "Sorption Distribution Coefficient Data," in Multimedia Environmental Pollutant Assessment System, Pacific Northwest Laboratory, Richland, Washington.

Prister, B. S., 1969. GKIAE Report by Atomizdat, Moscow (Canadian translation AEC/TR/7178 (1970), and USCEAR Rep. A/AC.82/G/L 1298).

Proescher et al. (F. Proescher, H. A. Seil, and A. W. Stillians), 1917. Am. J. Syph., Vol. 1 , pp. 347-405.

Rai, D., and J. M. Zachara, 1984. Chemical Attenuation Rates, Coefficients, and Constants in Leachate Migration, Volume 1: A Critical Review, EPRI, EA-3356, Research Project 2188-1.

Roberts, K. D., 1994. "A Survey of Naturally Occurring Uranium in Groundwater in Southwestern North Dakota," in Proceedings of North Dakota Water Quality, North Dakota State University Extension Service, Extension Agriculture Engineering Service, pp. 284-294.

Robinson et al. (M. F. Robinson, J. M. McKenzie, C. Thomson, and A. L. Van Rijn), 1973. Br. J. Nutr., Vol. 30, pp. 195-205.

Roseberry, A. M., and D. E. Burmaster, 1992. "Lognormal Distributions for Water Intake by Children and Adults," in Risk Analysis, Vol. 12, No. 1, pp. 99-104.

Rosenfeld, I., and O. A. Beath, 1964. Selenium, Geobotany, Biochemistry, Toxicity, and Nutrition, Academic Press, New York.

Rosoff, B., and H. Spencer, 1964. Nature (London), Vol. 202, pp. 410-411.

Schroeder et al. (H. A. Schroeder, J. J. Balassa, and I. H. Tipton), 1963. Journal of Chronic Diseases, Vol. 16, pp. 1047-1071.

Shannon, R. L., and D. S. Strayer, 1989. "Arsenic-Induced Skin Toxicity," in Human Toxicology, No. 8, pp. 99-104.

Snyder, F., and W. E. Cornatzer, 1958. Nature, Vol. 182, pp. 462.

Somerville, J., and B. Davies, 1962. American Health Journal, Vol. 54, pp. 54-56.

Stevens et al. (W. F. Stevens, W. Bruenger, D. R. Atherton, J. M. Smith, and G. N.

Taylor), 1980. "The Distribution and Retention of Hexavalent ${ }^{233} \mathrm{U}$ in the Beagle," in Radiation Research, No. 83, pp. 109-126. 
Sullivan et al. (M. F. Sullivan, P. S. Ruemmler, J. L. Ryan, and R. L. Bushhom), 1986. "Influence of Oxidizing or Reducing Agents on Gastrointestinal Absorption of U, Pu, Am, Cm, and Pm by Rats," in Health Physics, No. 50, pp. 223-232.

TAC (Technical Assistance Contractor), 1987. "Unpublished Field Notes, Bowman, North Dakota, Uranium Mill Tailings Site," unpublished report prepared by the TAC, Albuquerque, New Mexico, for the U.S. Department of Energy, UMTRA Project Office, Albuquerque Operations Office, Albuquerque, New Mexico.

TAC (Technical Assistance Contractor), 1986. "Unpublished Field Notes, Bowman, North Dakota, Uranium Mill Tailings Site," unpublished report prepared by the TAC, Albuquerque, New Mexico, for the U.S. Department of Energy, UMTRA Project Office, Albuquerque Operations Office, Albuquerque, New Mexico.

Tank, G., and C. A. Storvick, 1960. Journal of Dental Research, Vol. 39, pp. 473-488.

Ting, F. T. C., and M. L. Jones, 1986. "Geochemistry of Sodium in North Dakota Lignite," Thirteenth Biennial Lignite Symposium: Technology and Utilization of Low-Rank Coals, Bismarck, North Dakota, pp. 589-599.

Tipton et al. (I. H. Tipton, P. L. Stewart, and J. Dickson), 1969. Health Physics, Vol. 9, pp. 103-145.

Tracy et al. (B. L. Tracy, J. M. Quinn, J. Lahey, A. P. Gilman, K. Mancuso, A. P. Yagdinas, and D. C. Villeneuve), 1992. "Absorption and Retention of Uranium from Drinking Water by Rats and Rabbits," in Health Physics, Vol. 62, pp. 65-73.

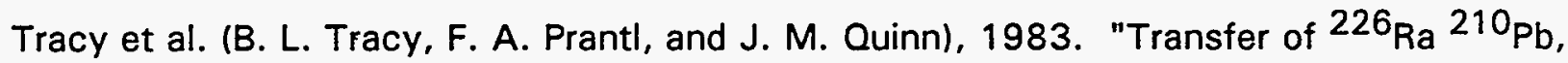
and Uranium from Soil to Garden Produce: Assessment of Risk," in Health Physics, Vol. 44, p. 469.

Tseng, W. P., 1977. "Effects and Dose-Response Relationship of Skin Cancer and Blackfoot Disease with Arsenic," in Environmental Health Perspectives, No. 19, pp. 109-119.

Van Zinderen Bakker, and J. F. Jaworski, 1980. Effects of Vanadium in the Canadian Environment, Ottawa, Canada, National Research Council of Canada, Associate Committee, Scientific Criteria for Environmental Quality.

Venugopal, B., and T. D. Luckey, 1978. "Chemical Toxicity of Metals and Metalloids," Metal Toxicity in Mammals, Plenum Press, New York, New York.

Webb, J. L., 1966. Enzymes and Metabolic Inhibitors, Academic Press, New York, New York.

Weigel, F., 1983. "Uranium and Uranium Compounds," Kirk-Othmer Encyclopedia of Chemical Technology, Vol. 23, third edition, M. Grayson, ed., John Wiley and Sons, New York, New York, pp. 502-547. 
WHO (World Health Organization), 1988. Vanadium, Environmental Health Criteria 81, published under the joint sponsorship of the United Nations Environment Programme, the International Labour Organisation, and the World Health Organization, Geneva, Switzerland.

WHO (World Health Organization), 1981. Arsenic, Environmental Health Criteria 18, published under the joint sponsorship of the United Nations Environment Programme, the International Labour Organisation, and the World Health Organization, Geneva, Switzerland.

Wrenn et al. (M. E. Wrenn, P. W. Durbin, B. Howard, J. Lipsztein, J. Rundo, E. T. Still, and D. L. Willis), 1985. "Metabolism of Ingested $U$ and Ra," in Health Physics, No. 48 , pp. 601-633.

Yakawa, M., and M. Suzuki-Yasumoto, 1980. Arch. Environ. Health, Vol. 35, pp. 36-44.

Yang et al. (G. Yang, R. Zhou, and S. Yin), 1989a. "Studies of Safe Maximal Daily Dietary Selenium Intake in a Seleniferous Area in China, 1," in J. Trace Elem.

Electrolytes Health Dis., Vol. 3(2), pp. 77-87.

Yang et al. (G. S. Yang, R. Zhou, and S. Yin), 1989b. "Studies of Safe Maximal Daily Dietary Selenium Intake in a Seleniferous Area in China: II, Relation Between Selenium Intake and the Manifestation of Clinical Signs and Certain Biochemical Alterations in Blood and Urine," in J. Trace Elem. Electrolytes Health Dis., Vol. 3(2), pp. 123-130.

Zeller, H. D., and J. M. Schopf, 1959. "Core Drilling for Uranium-Bearing Lignite in Harding and Perkins Counties, South Dakota and Bowman County, North Dakota," U.S. Geological Survey, Bulletin 1055-C, pp. 59-95.

\section{FEDERAL REGISTER}

52 FR 36000, Standards for Remedial Actions at Inactive Uranium Processing Sites; Proposed Rule, September 24, 1987.

\section{STATE CODE}

State of North Dakota Ground Water Protection Act, North Dakota Century Code Annotated, Title 23 (23-33-06), Health and Safety, Chapter 33, "Ground Water Protection."

\section{UNITED STATES CODE}

42 USC $\$ 7901$ et seq., Uranium Mill Tailings Radiation Control Act, November 8, 1978. 